Louisiana State University

LSU Digital Commons

Faculty Publications

Department of Geology and Geophysics

9-17-2007

\title{
Sediment flux and fate in the mississippi river diversion at west bay: Observation study
}

\author{
T. Mitchell Andrus \\ Coastal Engineering Consultants, Inc.
}

Samuel J. Bentley

Memorial University of Newfoundland

Follow this and additional works at: https://digitalcommons.Isu.edu/geo_pubs

\section{Recommended Citation}

Andrus, T., \& Bentley, S. (2007). Sediment flux and fate in the mississippi river diversion at west bay: Observation study. Coastal Sediments '07 - Proceedings of 6th International Symposium on Coastal Engineering and Science of Coastal Sediment Processes https://doi.org/10.1061/40926(239)55

This Conference Proceeding is brought to you for free and open access by the Department of Geology and Geophysics at LSU Digital Commons. It has been accepted for inclusion in Faculty Publications by an authorized administrator of LSU Digital Commons. For more information, please contact ir@lsu.edu. 
Louisiana State University

LSU Digital Commons

LSU Master's Theses

Graduate School

2007

\section{Sediment flux and fate in the Mississippi River Diversion at West Bay: observation study}

Thomas Mitchell Andrus

Louisiana State University and Agricultural and Mechanical College, mandrus@ceci-la.com

Follow this and additional works at: https://digitalcommons.lsu.edu/gradschool_theses

Part of the Oceanography and Atmospheric Sciences and Meteorology Commons

\section{Recommended Citation}

Andrus, Thomas Mitchell, "Sediment flux and fate in the Mississippi River Diversion at West Bay: observation study" (2007). LSU Master's Theses. 1910.

https://digitalcommons.1su.edu/gradschool_theses/1910

This Thesis is brought to you for free and open access by the Graduate School at LSU Digital Commons. It has been accepted for inclusion in LSU

Master's Theses by an authorized graduate school editor of LSU Digital Commons. For more information, please contact gradetd@lsu.edu. 


\title{
SEDIMENT FLUX AND FATE IN THE MISSISSIPPI RIVER DIVERSION AT WEST BAY: OBSERVATION STUDY
}

\author{
A Thesis \\ Submitted to the Graduate Faculty of the \\ Louisiana State University and \\ Agricultural and Mechanical College \\ in partial fulfillment of the \\ requirements for the degree of \\ Master of Science
}

in

The Department of Oceanography and Coastal Sciences

by

T. Mitchell Andrus

B.S., Louisiana State University, 1997

December, 2007 
To Hallie, Evelyn, and Kate. 


\section{ACKNOWLEDGMENTS}

Because of the many challenges which will undoubtedly face coastal planners, engineers, and scientists in the years to come, I felt compelled to study the effects of a restoration project which had actually been engineered and constructed. I must begin by acknowledging the support and information provided by the two sponsoring agencies of the West Bay Sediment Diversion project, the Louisiana Department of Natural Resources (LDNR) and the U.S. Army Corps of Engineers (USACE). The study also received monetary support from the Coastal Restoration and Enhancement through Science and Technology program (CREST) which is administered by the Louisiana Universities Marine Consortium (LUMCON) using funds provided by the National Ocean Service (NOS) of the National Oceanic and Atmospheric Administration (NOAA). It is my hope that this work will provide valuable information to build on in future sediment diversion planning efforts.

I would like to specifically thank Chris Knotts, Luke LeBas, and Russ Joffrion of the LDNR Coastal Engineering Division for giving me the latitude to begin this study during my time as an LDNR employee. Thanks to Dr. Bill Good for approving the use of LDNR equipment for the initial unfunded field work and to Brady Carter for his field support from airboat driving to the dirty work of mud sampling. Thanks to the LDNR and USACE project managers, John Hodnett and Greg Miller, respectively, for providing pertinent governmental data and information gathered for this project.

For a major advisor, I was fortunate enough to have Dr. Sam Bentley who peaked my interest in coastal geology, nurtured my ideas and curiosities, navigated me through funding proposals and academic hurdles, provided superior scientific tutelage, and most of all served as a invaluable mentor who knew when to push for excellence and a friend who guided me past any doubts in my work. Thanks also to Dr. Jaye Cable for imparting her insight gained from past 
studies of river diversions and radio-chemistry, and to Dr. James Coleman for sharing his wealth of knowledge collected over many years of studying the deltaic processes of the Mississippi River and West Bay in particular.

In addition to this fine academic guidance, LSU's Coastal Studies Institute (LSU-CSI) also provided a top-notch field support group led by Steven Dartez with assistance from Darren Depew. Steve participated in devising sampling plans, tailored instrument deployments to specific study requirements, handled data with great care, and unselfishly assisted with data processing. I appreciate his attention to detail and the friendship that we have developed.

I must also thank my current employer, Coastal Engineering Consultants, Inc. (CEC), who embraced my pursuit of this degree as a full-time CEC employee. I would like to specifically thank Dr. Michael Stephen, Michael Poff, Bethany Savioe, Jamie Cohlmeyer, and Jonathon Puls for the moral support and technical assistance they provided.

Finally, this effort would not have been possible without the endless encouragement from my family and friends. My mom and dad have always been confident in my abilities and perseverance, even when I was not. My wife, Hallie, deserves this degree as much or more than I do. As we embarked on this journey together, she bore our two children and many times must have felt like a single parent while I was off sampling mud, working in the laboratory, preparing for tests and presentations, or writing this thesis. This experience has made my love and respect for her even stronger than before. And lastly, my young two daughters, Evelyn and Kate, served as my inspiration to complete this endeavor. It is my hope that this document may one day inspire them to pursue their intellectual curiosities as far as they may desire. 


\section{TABLE OF CONTENTS}

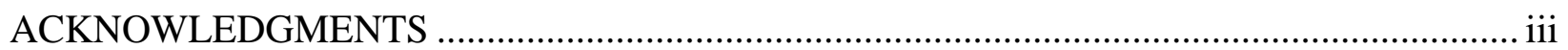

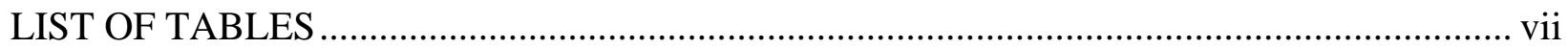

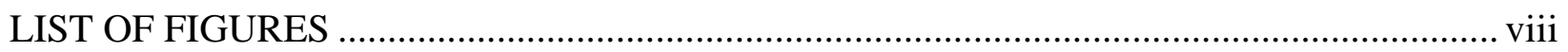

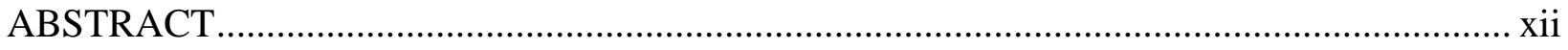

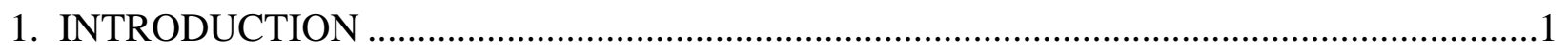

1.1 Deltaic Processes of the Lower Mississippi River ..........................................................

1.2 History of the West Bay Subdelta Complex........................................................................

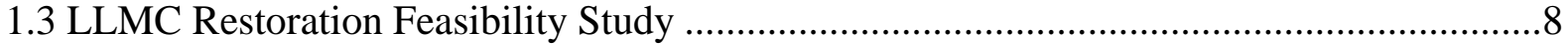

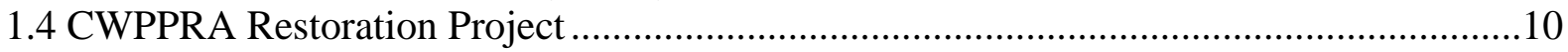

1.4.1 Project Goals and Objectives....................................................................................11

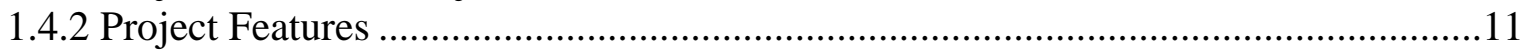

1.4.3 Design Considerations ...........................................................................................12

1.4.4 Project Construction .............................................................................................16

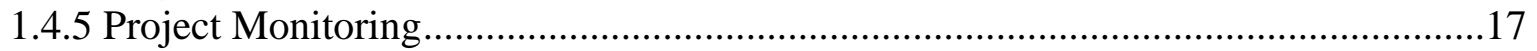

1.5 Previous Studies of Engineered Diversions......................................................................17

1.6 Objectives of This Study .............................................................................................21

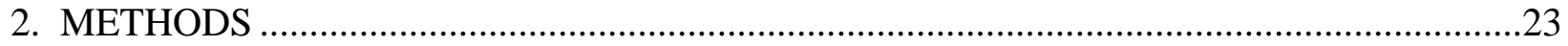

2.1 Sediment Sampling and Analysis .............................................................................23

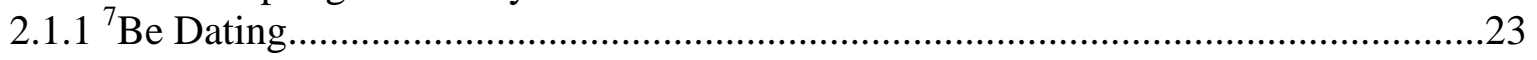

2.1.2 Sediment Collection ..........................................................................................23

2.1.3 Laboratory Analyses...............................................................................................26

2.1.4 Sediment Accumulation Rates (SAR) ................................................................27

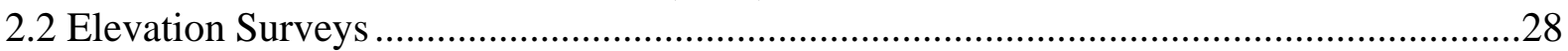

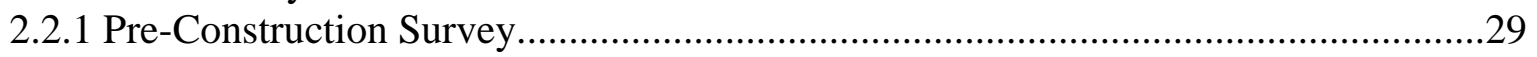

2.2.2 Post-Construction Surveys ……………………………………………………... 30

2.3 Flow and Turbidity Measurements...................................................................................32

2.3.1 Instrument Deployments......................................................................................32

2.3.2 Long-Term Measurements ........................................................................................35

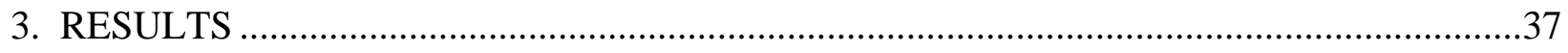

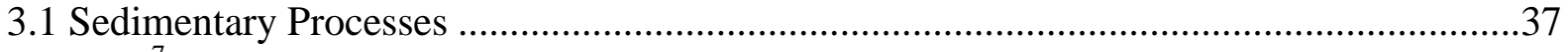

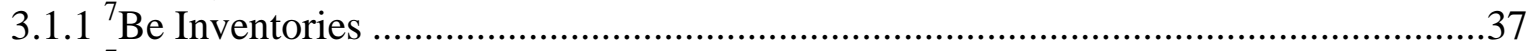

3.1.2 ${ }^{7}$ Be Activity Profiles and X-radiographs..................................................................37

3.1.3 Grain Size Analyses..............................................................................................46

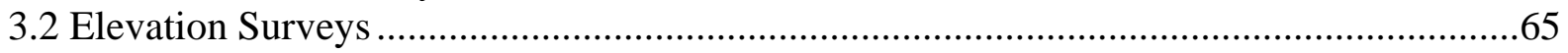

3.3 Mississippi River Hydraulics......................................................................................68

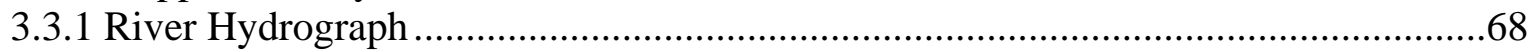

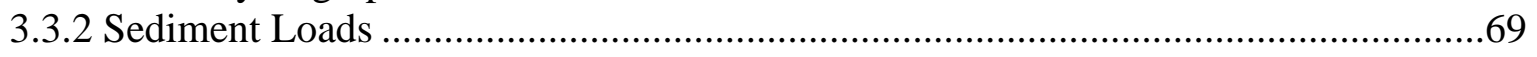

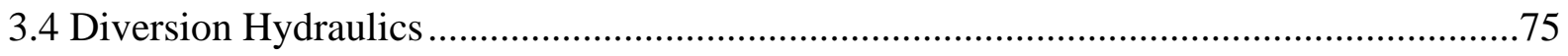

3.4.1 USACE Flow Measurements.....................................................................................75 
3.4.2 LSU CSI Flow Measurements ...............................................................................78

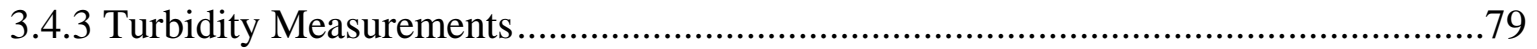

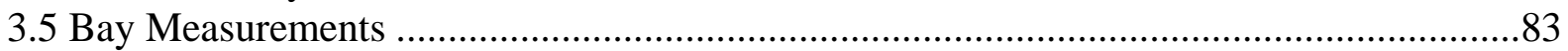

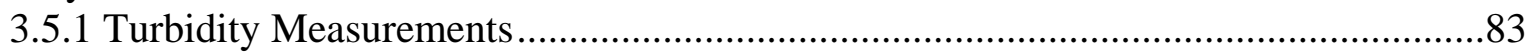

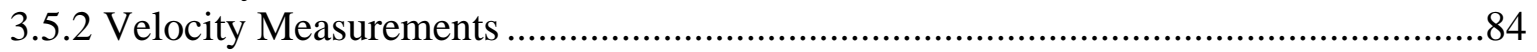

3.5.3 Tide Measurements.................................................................................................84

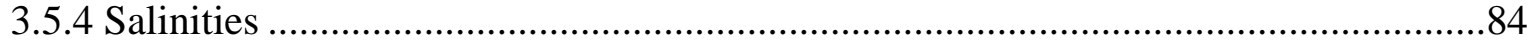

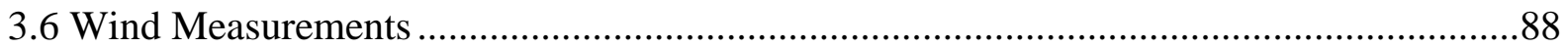

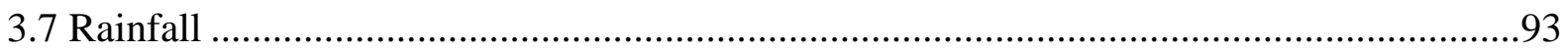

3.8 Satellite Imagery Analysis..............................................................................................94

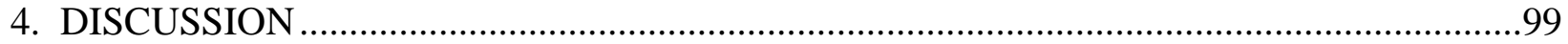

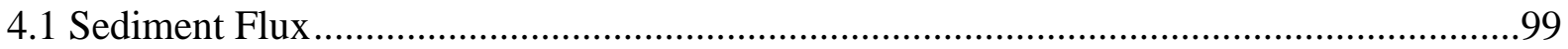

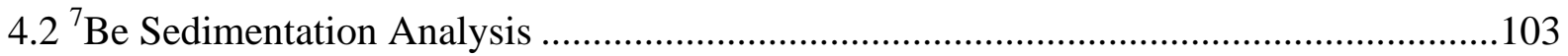

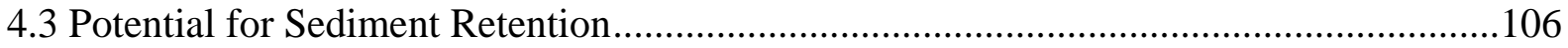

4.4 Sediment Dispersal ..................................................................................................107

4.5 Seasonal and Spatial Patterns of Fluvial Influence ........................................................114

4.6 Storm Influences on Depositional Record....................................................................119

4.7 Comparison with Other Diversions and Deltas ..................................................................125

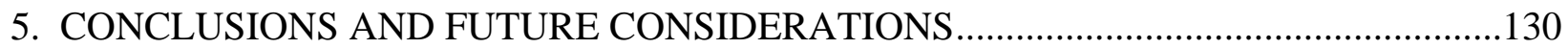

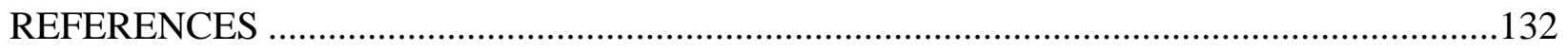

APPENDIX A: HISTORIC MAPS OF THE MISSISSIPPI RIVER DELTA …………..............138

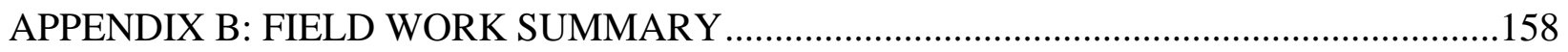

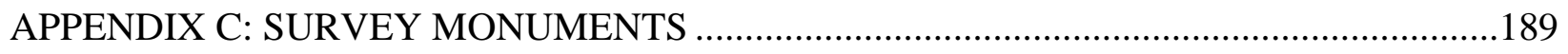

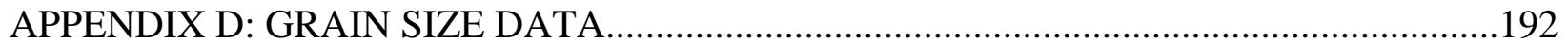

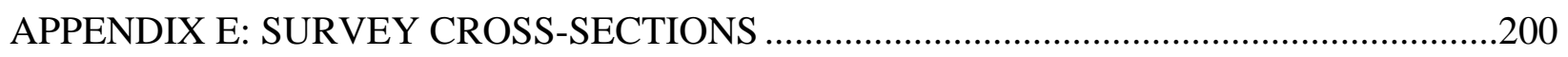

APPENDIX F: SUSPENDED PARTICLE MATTER CALCULATION SHEET ........................207

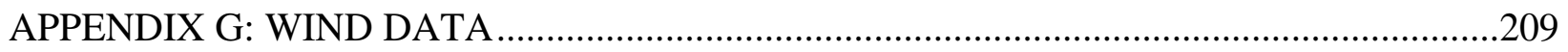

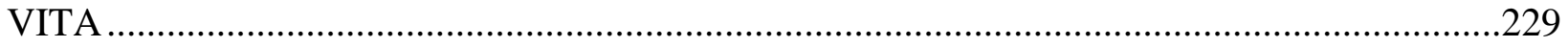




\section{LIST OF TABLES}

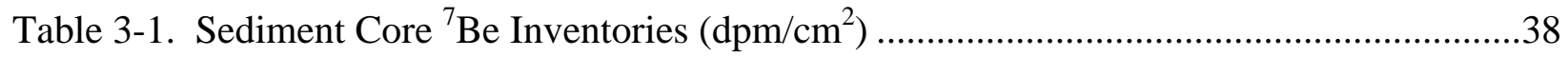

Table 3-2. Average Median Grain Sizes (microns) for Top $10 \mathrm{~cm}$.............................................64

Table 3-3. Quarterly Wind Direction Percentages - Burl 1 Weather Station at Southwest Pass..91

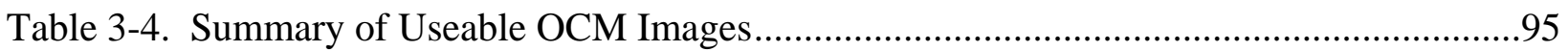

Table 3-5. Area of Sediment Plume Passing Through Diversion (nLw 555 > 7)..........................96

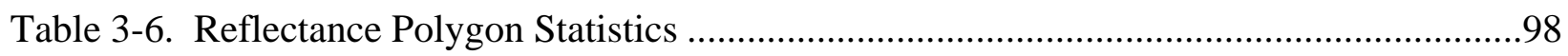

Table 4 - 1. Mississippi River Total Suspended Sediment Concentrations ..................................101

Table 4 - 2. Sediment Flux Estimations Based on Observed Diversion Flows ............................103

Table 4 - 3. Sediment Accumulation Rates (cm/mo).................................................................104

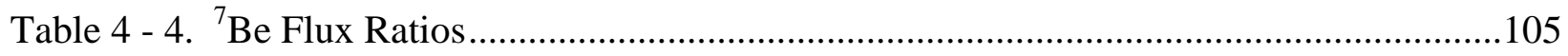

Table 4 - 5. Estimated Potential Sedimentation Rates ....................................................................106

Table 4 - 6. Estimation of Near-Bottom Orbital Velocities for Various Wind Conditions ..........113

Table 4 - 7. Summary of Volumetric Change Calculations Using the End Area Method...........123

Table 4 - 8. Summary of Diversions on the Lower Mississippi River below Natchez................127

Table 4 - 9. Comparison of Wax Lake and West Bay Delta Building Parameters......................128 


\section{LIST OF FIGURES}

Figure 1-1. Mississippi River Drainage Basin .....................................................................2

Figure 1-2. Historic Delta Complexes of the Mississippi River ...............................................3

Figure 1-3. Mississippi River Delta Cycle Growth and Decay Curve........................................4

Figure 1-4. Regressive Depositional Model of the Mississippi River Deltaic Plain .....................5

Figure 1-5. Modern Mississippi River Subdeltas ............................................................6

Figure 1-6. West Bay Subdelta Evolution .........................................................................

Figure 1-7. Project Area Marsh Loss Comparison .................................................................8

Figure 1-8. Land Extent in the West Bay Subdelta Complex .................................................9

Figure 1-9. Project features of the West Bay CWPPRA Project MR-03..................................13

Figure 1-10. Proposed SRED Locations .........................................................................15

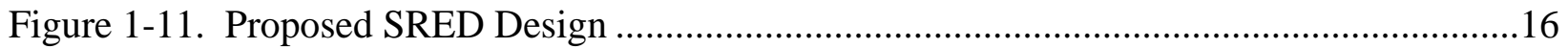

Figure 1-12. West Bay Diversion Theoretical Dredge Cut Section........................................17

Figure 1-13. West Bay Diversion Theoretical Dredge Cut Profile...........................................18

Figure 1-14. West Bay Diversion Under Construction.......................................................19

Figure 1-15. Comparison of River Flow, Wind and Sediment Discharge Peaks ........................20

Figure 2-1. West Bay Sediment Sampling Plan..............................................................24

Figure 2-2. West Bay Pre-Construction Survey Layout .....................................................31

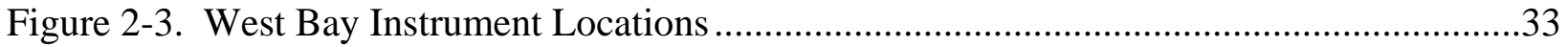

Figure 2-4. ADCP Survey Locations at West Bay Diversion Cut ............................................34

Figure 3-1. ${ }^{7}$ Be Inventory Bar Graphs for Sites WB01 - WB03 ..............................................39

Figure 3-2. ${ }^{7}$ Be Inventory Bar Graphs for Sites WB03 - WB06 ...........................................40

Figure 3-3. ${ }^{7}$ Be Inventory Bar Graphs for Sites WB07 - WB09 .............................................41

Figure 3-4. ${ }^{7}$ Be Inventory Bar Graphs for Sites WB10 - WB12 ...........................................42 


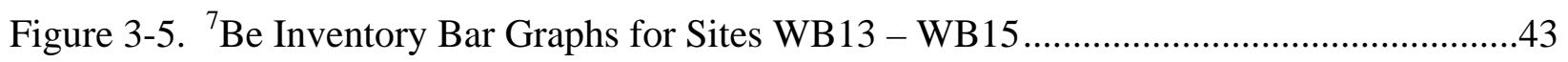

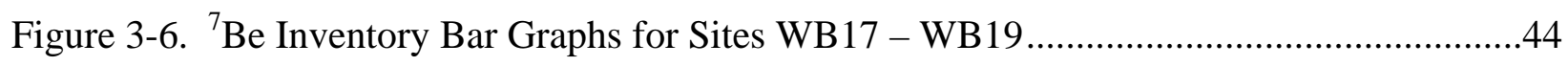

Figure 3-7. ${ }^{7}$ Be Inventory Bar Graphs for Sites WB21 \& WB22 _................................................45

Figure 3-8. ${ }^{7}$ Be Activity Profiles and X-Radiographs for Site WB01 ...........................................

Figure 3-9. ${ }^{7}$ Be Activity Profiles and X-Radiographs for Site WB02 ............................................48

Figure 3-10. ${ }^{7}$ Be Activity Profiles and X-Radiographs for Site WB03 ........................................49

Figure 3-11. ${ }^{7}$ Be Activity Profiles and X-Radiographs for Site WB04 …..................................50

Figure 3-12. ${ }^{7}$ Be Activity Profiles and X-Radiographs for Site WB05 ……................................51

Figure 3-13. ${ }^{7}$ Be Activity Profiles and X-Radiographs for Site WB06 ………............................52

Figure 3-14. ${ }^{7}$ Be Activity Profiles and X-Radiographs for Site WB07 ......................................53

Figure 3-15. ${ }^{7}$ Be Activity Profiles and X-Radiographs for Site WB08 ……….............................54

Figure 3-16. ${ }^{7}$ Be Activity Profiles and X-Radiographs for Site WB09 ……................................55

Figure 3-17. ${ }^{7}$ Be Activity Profiles and X-Radiographs for Site WB10 ………............................56

Figure 3-18. ${ }^{7}$ Be Activity Profiles and X-Radiographs for Site WB12 …................................57

Figure 3-19. X-Radiographs for Site WB13 …………….....................................................

Figure 3-20. ${ }^{7}$ Be Activity Profiles and X-Radiographs for Site WB15 …..................................59

Figure 3-21. ${ }^{7}$ Be Activity Profiles and X-Radiographs for Site WB17 ……................................60

Figure 3-22. ${ }^{7}$ Be Activity Profiles and X-Radiographs for Site WB19 .......................................61

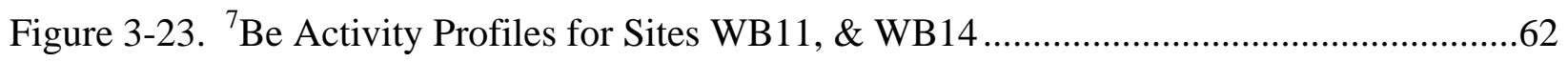

Figure 3-24. ${ }^{7}$ Be Activity Profiles for Sites WB21 \& WB22 ……………………………...........63

Figure 3-25. Median Grain Sizes for Site WB05.........................................................................64

Figure 3-26. Pre-construction Bathymetric Contours Measured in 2003 ......................................66

Figure 3-27. Post-construction Bathymetric Contours Measured in April 2006 ...........................67

Figure 3-28. Historical Mississippi River Flows at Tarbert Landing from 1977 to 2006 .............68 
Figure 3-29. Average Mississippi River Yearly Hydrograph at Tarbert Landing 69

Figure 3-30. Mississippi River Suspended Sediment Concentrations from 1977 to 2006 ...........70

Figure 3-31. Coarse and Fine Mississippi River Sediment Loads at Tarbert Landing................70

Figure 3-32. Yearly Averages of Flows and Sediment Concentrations at Tarbert Landing.........71

Figure 3-33. Yearly Averages of Flows and Sediment Percentages at Tarbert Landing..............72

Figure 3-34. Fine Sediment Concentration vs. River Flow at Tarbert Landing ........................73

Figure 3-35. Coarse Sediment Concentration vs. River Flow at Tarbert Landing ......................73

Figure 3-36. Mississippi River Flows at Belle Chase, LA ...................................................74

Figure 3-37. Coarse and Fine Mississippi River Sediment Loads at Belle Chase, LA ...............75

Figure 3-38. Measured Diversion Flows from Dec. '03 to Nov. '06.......................................76

Figure 3-39. Measured River Flows Upstream of Diversion from Dec. '03 to Nov. '06.............77

Figure 3-40. Diversion Flows vs. River Flows ...........................................................77

Figure 3-41. Hydrograph Results from LSU-CSI Flow Study in the Diversion Cut....................79

Figure 3-42. Turbidity Results from LSU-CSI Study in the Diversion Cut ..............................80

Figure 3-43. Calibration of Turbidity Sensor vs. Suspended Particle Matter (SPM) .................81

Figure 3-44. Estimated (SPM) in the Diversion Cut During LSU-CSI Flow Study.....................82

Figure 3-45. Estimated (SPM) at Mid-bay Site During LSU-CSI Bay Study ...........................83

Figure 3-46. Velocity Measurements at Mid-bay Site During 1st Deployment..........................85

Figure 3-47. Velocity Measurements at Mid-bay Site During 2nd Deployment........................86

Figure 3-48. Water Depths Recorded at Mid Bay ….........................................................87

Figure 3-49. Water Depths Recorded at Diversion..........................................................87

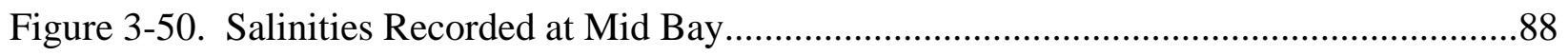

Figure 3-51. Average Monthly Wind Speeds from NDBC Station Burl 1 at Southwest Pass .....89

Figure 3-52. Composite Wind Rose Plot from NDBC Station Burl 1 at Southwest Pass ............90 
Figure 3-53. Wind Records from NDBC Station Burl 1 at Southwest Pass During Bay Study...92

Figure 3-54. Rainfall at New Orleans International Airport During Bay Study.... .93

Figure 3-55. Processed OCM Satellite Images ................................................................95

Figure 3-56. Radiance Contour Mapping .....................................................................97

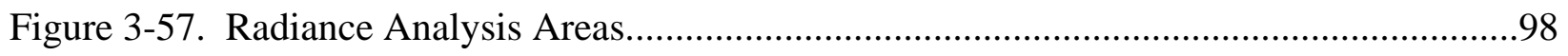

Figure 4-1. Estimated Sediment Loads Passing Through the Diversion .................................102

Figure 4-2. Conceptual Illustration of Five Major Stages in River Sediment Dispersal ............107

Figure 4-3. Illustration of Sediment Dispersal Considerations in the West Bay Study Area.....115

Figure 4-4. West Bay Flow and Total ${ }^{7}$ Be Inventory Analysis ..........................................116

Figure 4-5. Spatial Distributions of ${ }^{7}$ Be Inventories........................................................118

Figure 4-6. Track of Hurricane Katrina and Spatial Extent of Hurricane Force Winds .............120

Figure 4-7. Plan View of Volumetric Change Calculation Area ...........................................122

Figure 4-8. Tulane University Box Coring Study Conducted on Continental Shelf .................125

Figure 4-9. Location Map of Atchafalaya and Wax Lake Bayhead Deltas .............................128 


\begin{abstract}
Land-building sediment diversions, such as the Mississippi River Diversion at West Bay, can be used as important building blocks in the conservation and restoration of Mississippi Delta wetlands. Sediment deposition and retention patterns were studied in the West Bay diversion outfall area through analyses of sediment cores, hydrodynamics, and bathymetry. Cores and xray samples were collected at twenty stations in March 2004, August 2004, November 2005, and April 2006. Cores were analyzed for grain-size distributions and ${ }^{7}$ Be activities, in order to examine patterns of recent sediment deposition. In comparing ratios of total ${ }^{7}$ Be inventory to atmospheric ${ }^{7} \mathrm{Be}$ deposition rates, it was estimated that $10 \%, 60 \%$, and $30 \%$ of the cores experienced net accretion, net erosion, and no deposition, respectively. Turbidity and velocity data collected during instrument deployments along with historical Mississippi River flows and sediment loads were used to estimate an average sediment influx of $2.9 \times 10^{6}$ tons/year $\left(2.6 \times 10^{9}\right.$ $\mathrm{kg} /$ year). A sediment trapping efficiency of 25 - 50\% was estimated by comparing sediment influx with ${ }^{7} \mathrm{Be}$ penetration depths observed. This estimation could not be verified by bathymetric surveys conducted in April 2006 and compared to pre-construction surveys from 2003. Volumetric change calculations estimated a loss of over $4.16 \times 10^{6} \mathrm{yd}^{3}\left(3.18 \times 10^{6} \mathrm{~m}^{3}\right)$ of sediment from the bay bottom. It is speculated that these losses were caused by Hurricane Katrina which made landfall on August 29, 2005 approximately 15 nautical miles (28 km) from the study area. Potential deltaic growth rates of between 51 ac/year (21 ha/year) and 143 ac/year (59 ha/year) were estimated for the diversion by comparing delta growth parameters estimated in this study with the Wax Lake Delta. These estimates suggest that delta-building processes at West Bay may continue following a typical subdelta growth curve of 100 - 150 years, meaning peak development of deltaic wetlands could be decades away. Therefore, future planning for diversions should consider coastal process which could potentially counter environmental
\end{abstract}


benefits and engineering strategies should place as much focus on receiving area configuration and trapping efficiency as sediment delivery in order to maximize sediment retention. 


\section{INTRODUCTION}

In the modern Mississippi Delta, subdeltas represent important and dynamic components

of the landscape and sediment delivery system. In a general sense, we understand the processes that influence the growth and decay of subdeltas. However, our knowledge is insufficient to allow prediction of sediment deposition and retention within subdeltas, and so we cannot reliably model the processes and resultant dynamic geomorphology. This inadequacy is problematic, because subdeltas, like the one being built at West Bay, are being used as important building blocks in the conservation and restoration of Mississippi Delta lands and wetlands. The overall goal of this study is to elucidate our understanding of fluvial-marine sediment dispersal and retention within subdeltas, thus enhancing assessment, planning, and predictive capabilities for the West Bay Diversion and for future land-building projects of comparable design.

\subsection{Deltaic Processes of the Lower Mississippi River}

The geologic framework of the Lower Mississippi River (LMR) has evolved through actions of a number of riverine and coastal processes. The alluvial valley of the Mississippi River ranges from 25 to $125 \mathrm{mi}$ (40 to $201 \mathrm{~km}$ ) wide, is $600 \mathrm{mi}$ (965 km) long, and covers approximately $50,000 \mathrm{mi}^{2}\left(130,000 \mathrm{~km}^{2}\right)$. At the climax of the last glacial maximum, the alluvial valley began its formation as ice masses began to melt, increasing water flow. Development continued until sea level began to approach its present level between 5,000 and 8,000 years ago. During this time frame, the Mississippi River Valley was heavily braided in nature and deposited mostly gravel and coarse sands; fines were transported off the shelf. As sea level began to rise, deposition of finer sediments became more prevalent upstream, beginning the formation of Louisiana’s deltaic plain (Fisk, 1951). 
Today, the Mississippi River Drainage Basin covers more than 1,245,000 $\mathrm{mi}^{2}(3,225,000$ $\mathrm{km}^{2}$ ), and encompasses $41 \%$ of the contiguous United States and a portion of two Canadian provinces (Fig. 1-1). The Mississippi River has an annual average flow rate of 495,000 $\mathrm{ft}^{3} / \mathrm{s}$ $\left(14,000 \mathrm{~m}^{3} / \mathrm{s}\right)$ and a freshwater discharge onto the continental shelf of 470,000,000 ac-ft (580 $\mathrm{km}^{3}$ ) per year. The river discharge into the Gulf of Mexico is distinctly seasonal, with highest flows occurring between March and May and lowest flows occurring during August and October (USACE, 2004).

\section{Mississippi River Drainage Basin}

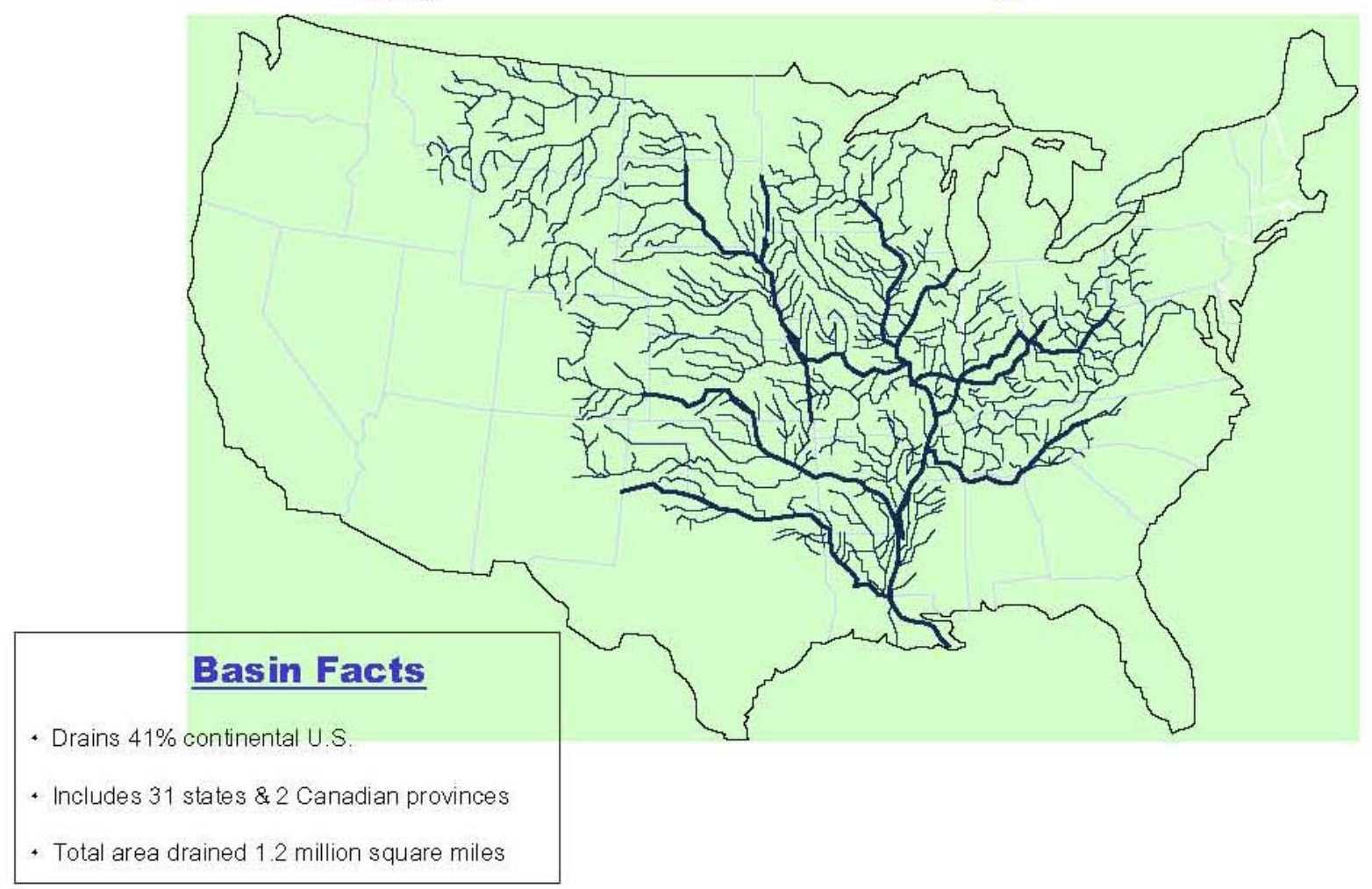

Figure 1-1. Mississippi River Drainage Basin

(USACE, 2004)

The present sea-level high stand has given rise to delta-building processes of the Mississippi River that are cyclic in nature and involve a wide array of depositional environments. 
Through alternating regressive (fluvial/depositional) and transgressive (marine/erosional) phases, the Mississippi River has occupied at least six major courses in the deltaic plain during the Holocene geologic period. The resulting major historic delta complexes of the Mississippi River are shown in Figure 1-2 (Roberts, 1997). The modern delta complex is the Balize delta, which is commonly referred to as the "birdfoot" delta.

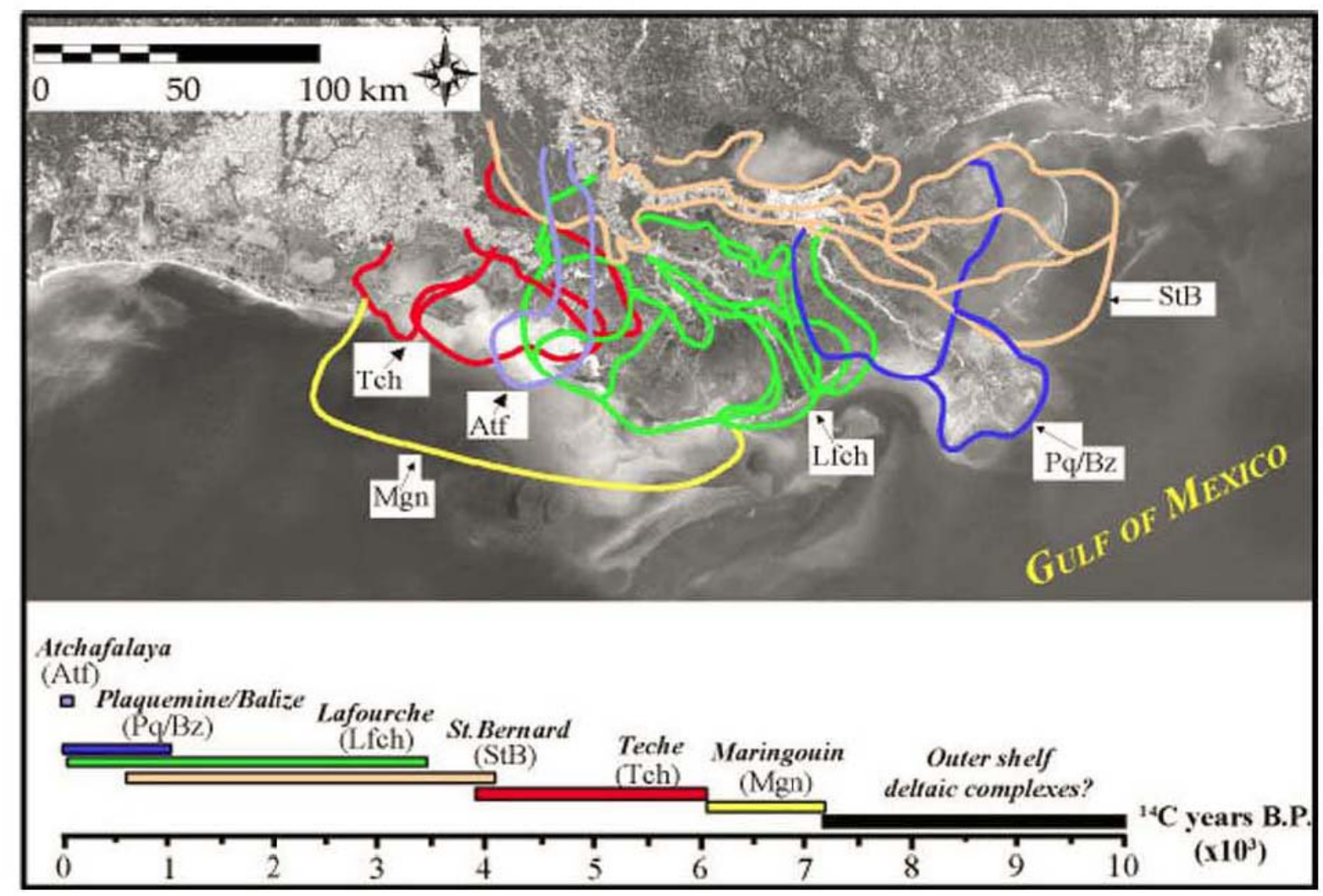

Figure 1-2. Historic Delta Complexes of the Mississippi River (Modified from Frazier, 1967)

Historic trends for these river courses include a duration of 1000-2000 years, an average depositional coverage of $5800 \mathrm{mi}^{2}\left(15,000 \mathrm{~km}^{2}\right)$, and sedimentary sequences of up to $100 \mathrm{ft}$ (30 m) thick (Roberts, 1997). Each new delta cycle begins with an epidode of avulsion, as the river seeks the most direct path to the Gulf of Mexico. A new route is carved through backswamp areas, often following old distributary channels, after which depositional processes initiate 
formation of lacustrine deltas, then bayhead and shelf deltas, as accommodation space fills in a downstream direction. Figure 1-3 shows a graphical representation of the growth and destructive phases of the Mississippi River delta cycle.

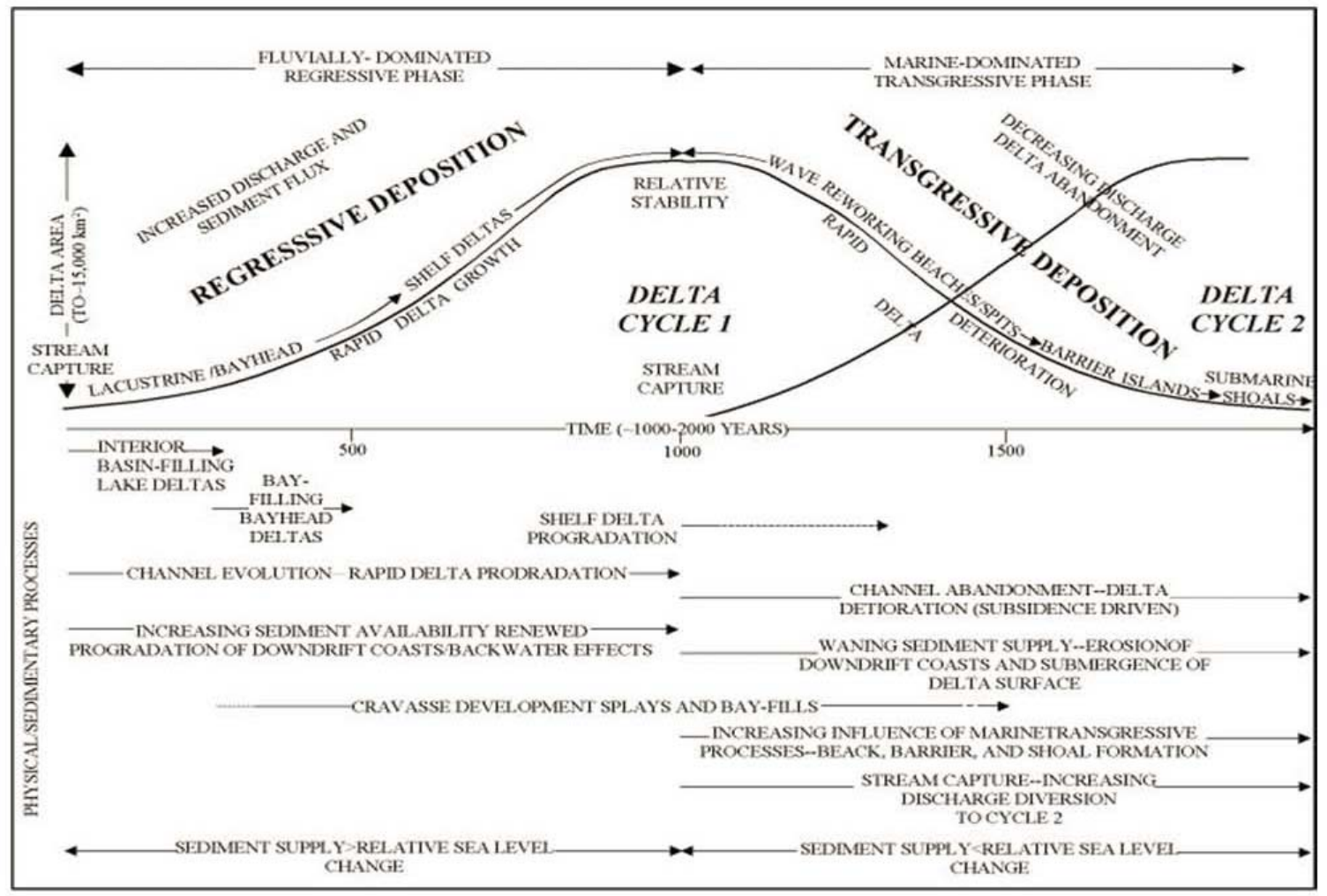

Figure 1-3. Mississippi River Delta Cycle Growth and Decay Curve (Roberts, 1997)

As available accommodation space in a deltaic receiving basin reaches a minimum, hydraulic efficiency decreases, thus hindering delivery of sediment to the floodplains and delta front. The decrease of sediment supply then allows marine processes to dominate. Erosion and subsidence lead to reworked sediments, changing habitats, retreating shorelines and eventual tributary detachment. Resulting barrier islands are then breached and overwashed and finally become submerged shoals. These transgressive delta phases are graphically depicted in Figure 1-4. 


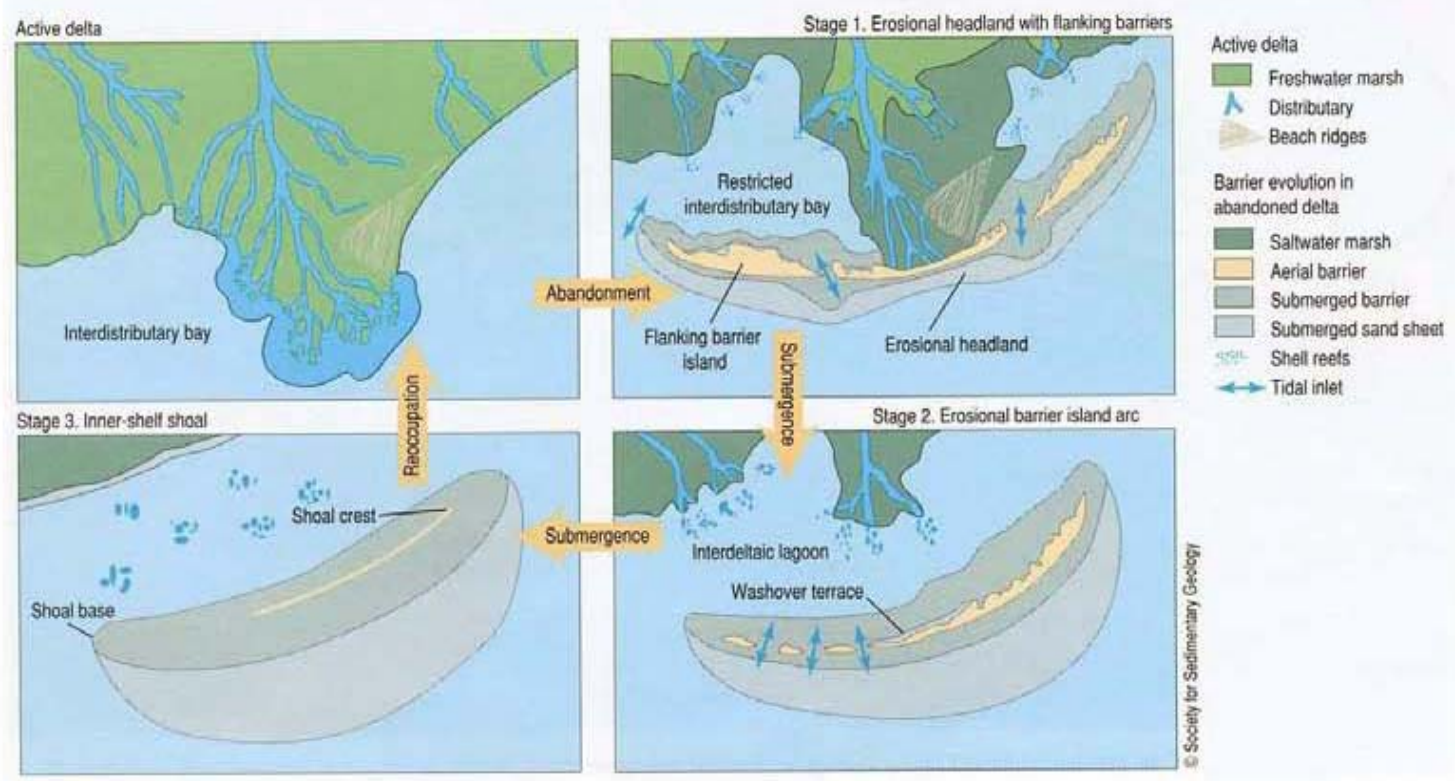

Figure 1-4. Regressive Depositional Model of the Mississippi River Deltaic Plain (Penland and Boyd, 1981)

\subsection{History of the West Bay Subdelta Complex}

During the first half of the delta cycle when fluvial-depositional processes are dominant, shelf deltas are built through repeated subdelta development. This pattern is similar to the larger delta cycle, but occurs over smaller spatial and temporal scales than the delta cycle. Natural levees of major distributaries are broken by overbank floods, creating crevasses that deliver sediment-laden waters to interdistributary bays and basins. Varying energy regimes tend to grade the sediments, delivering prodelta clays and detritus to the periphery of active deposition, followed by intermediate silts and clays that are colonized by marsh, and finally sands, which are deposited closest to the crevasse origination (Coleman and Gagliano, 1964). Subdelta deposits are generally less than $30 \mathrm{ft}(10 \mathrm{~m})$ thick and up to $115 \mathrm{mi}^{2}\left(300 \mathrm{~km}^{2}\right)$ in area. Life cycle development is on the order of 100 - 150 years from initiation to abandonment (Coleman and Prior, 1982). A subdelta is a microcosm of overall delta model shown in Figure 1-3 (Roberts, 1997). 
The West Bay Subdelta Complex is located in the Mississippi River Delta in Plaquemines Parish, Louisiana. It is one of the six subdelta complexes defined by Coleman and Gagliano (1964) comprising the most recent framework of the modern Birdfoot Delta as shown in Figure 1-5.

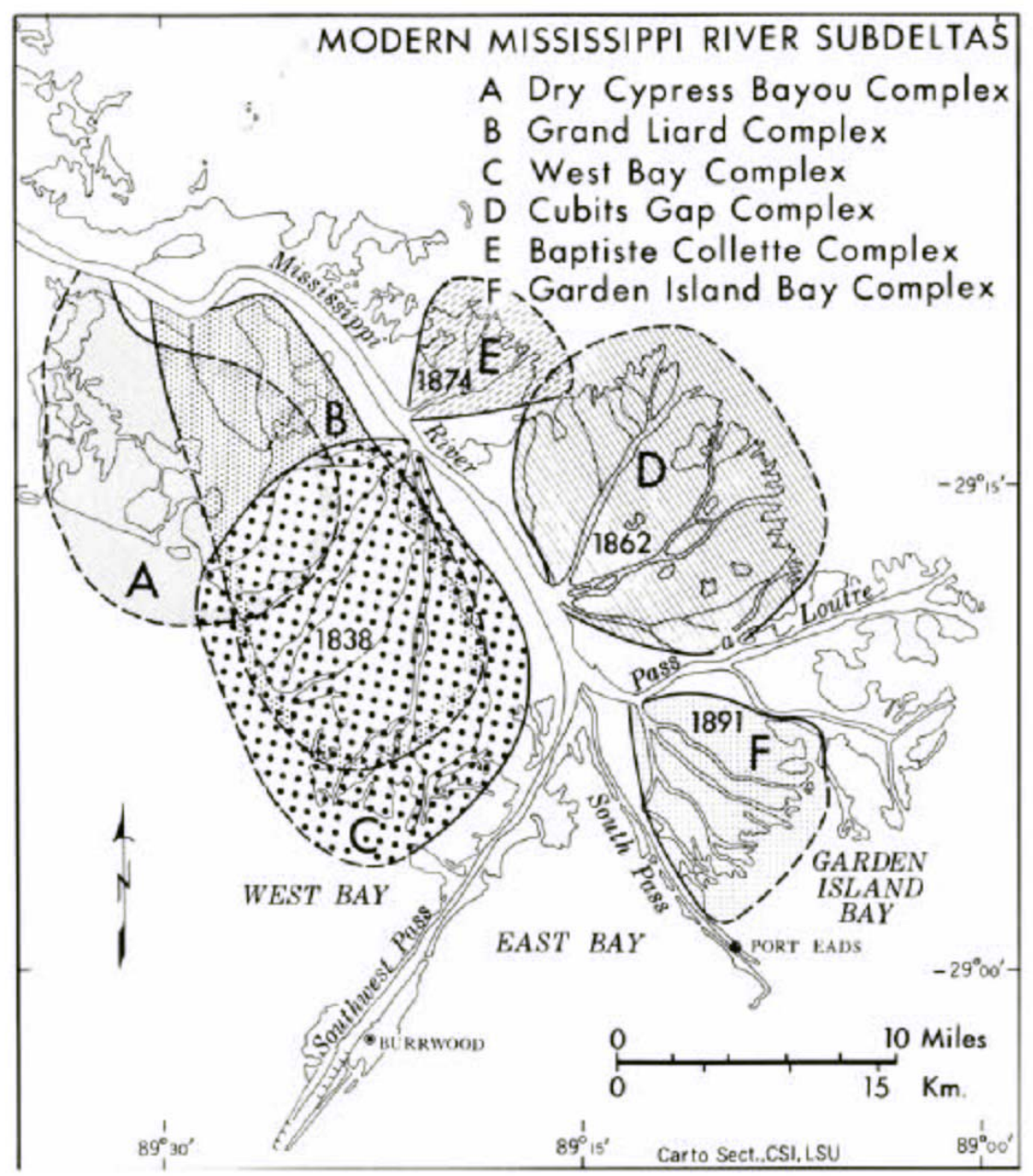

Figure 1-5. Modern Mississippi River Subdeltas

(Coleman and Gagliano, 1964)

Historical dating through map studies has shown that the West Bay subdelta originated around 1838 as a break in the natural Mississippi River levee during flood stage creating an intricate land-building crevasse splay. The location of this break, which is still hydraulically open, is just below the present day town of Venice, LA and is known as “The Jump”. Figure 1-6 
shows a progression of subdelta growth and initial stage of deterioration over a timescale from 1845 to 1958.

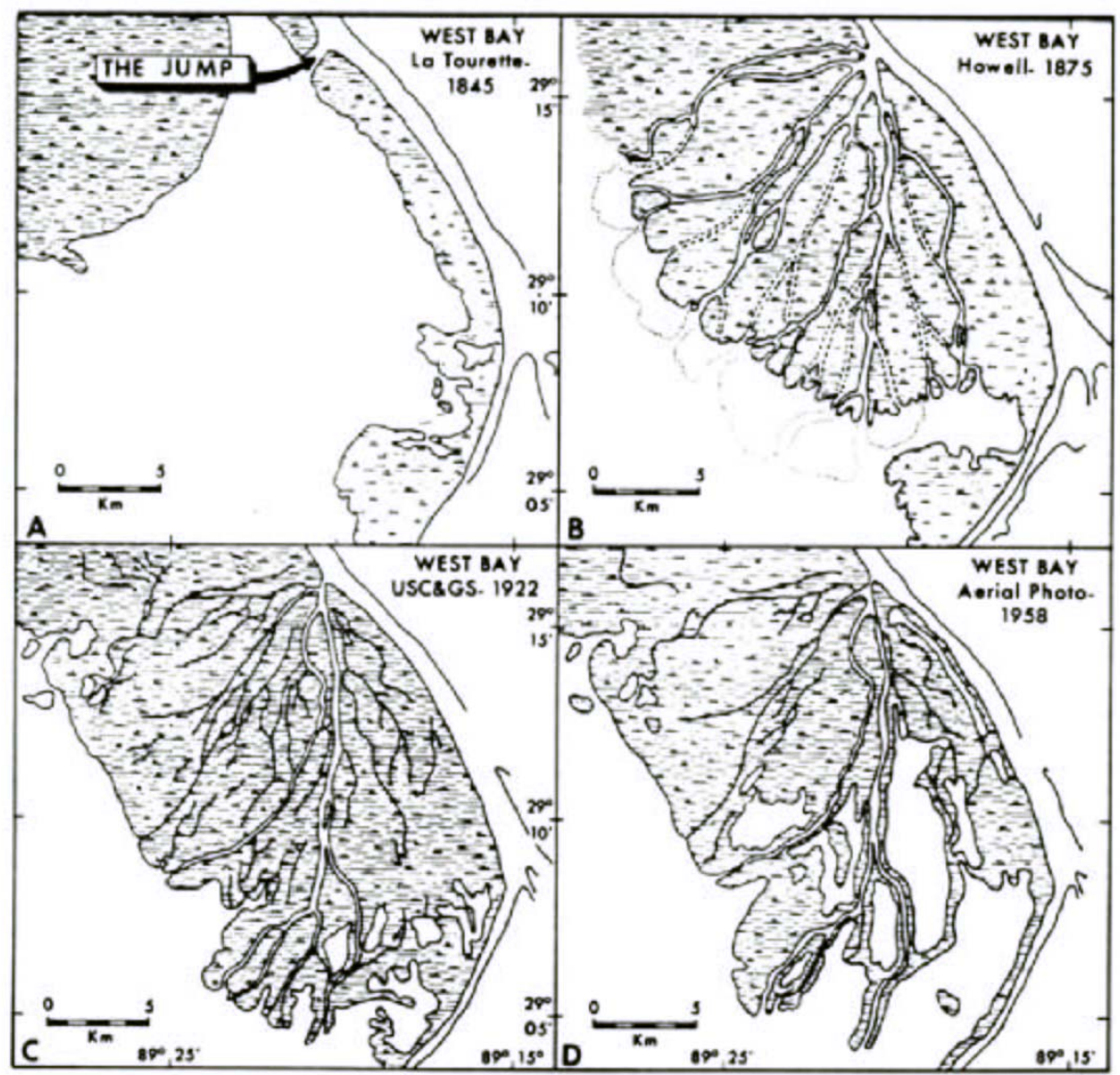

Figure 1-6. West Bay Subdelta Evolution (Coleman and Prior, 1982)

This original study of subdelta evolution on the Birdsfoot Delta, performed by Louisiana State University's Coastal Studies Institute (LSU CSI), can be extended to more recent conditions by comparing these past map studies with recent imagery. Figure 1-7 illustrates falsecolor IR imagery from 1998 of the West Bay/Head of Passes region, compared to a 1953 topographic map of the same area, at the same scale. Extensive regions mapped as marsh in 1953 are now open water. Our study area is outlined in black, west of the river. 

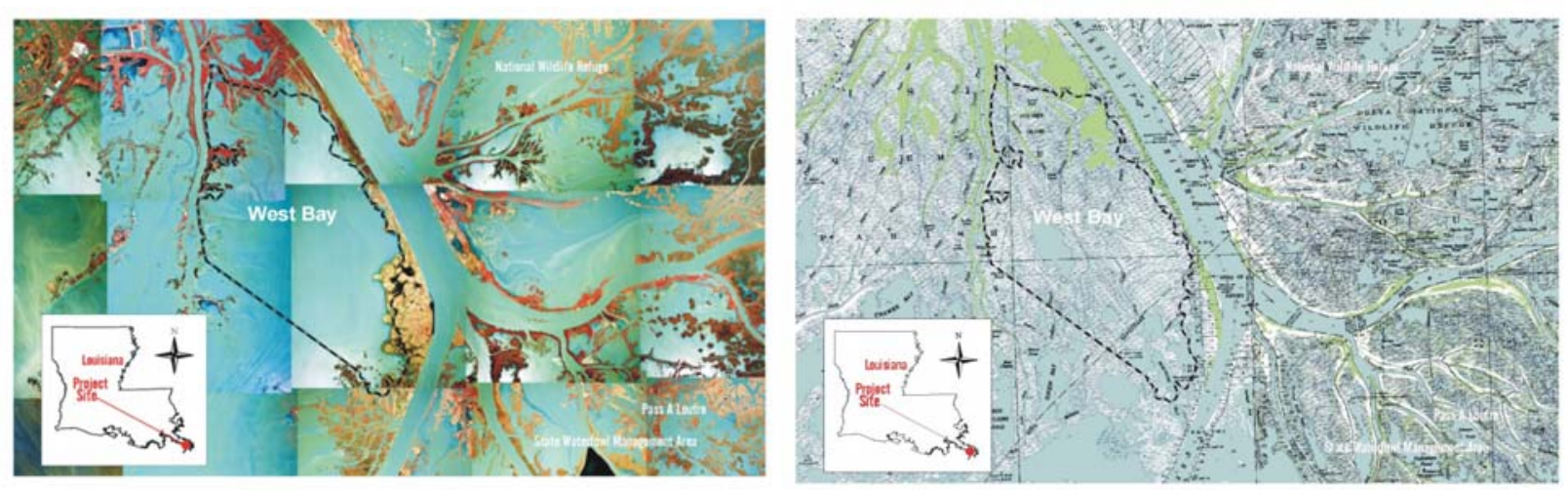

Figure 1-7. Project Area Marsh Loss Comparison

The extensive mapping study by LSU CSI is summarized in the subdelta life cycle curve shown in Figure 1-8 (Coleman, 2006). By the mid 1900's, the West Bay subdelta entered the natural deterioration phase of its life cycle that was possibly accelerated by river channelization, canal dredging, and decreased sediment loads in the Mississippi River. As hydraulic efficiency of the subdelta decreased, the valuable inputs of fresh water, nutrients, and sediment declined and the marsh succumbed to erosion and subsidence. Additional historic maps of the Mississippi River Delta that were used in the mapping study are presented in Appendix A.

\subsection{LLMC Restoration Feasibility Study}

The concept of large scale diversions of sediment from the Mississippi River was evaluated in a Reconnaissance Report produced in 1984 for the Land Loss and Marsh Creation (LLMC) study. Sediment diversions were determined to be potentially viable methods for marsh creation and were therefore carried over into a Feasibility Stage analysis conducted under the LLMC study (USACE, 2001).

Eight potentially favorable reaches were identified along the Mississippi River AHP to evaluate as sites for large-scale diversions of sediment-laden water. Five sites were above 


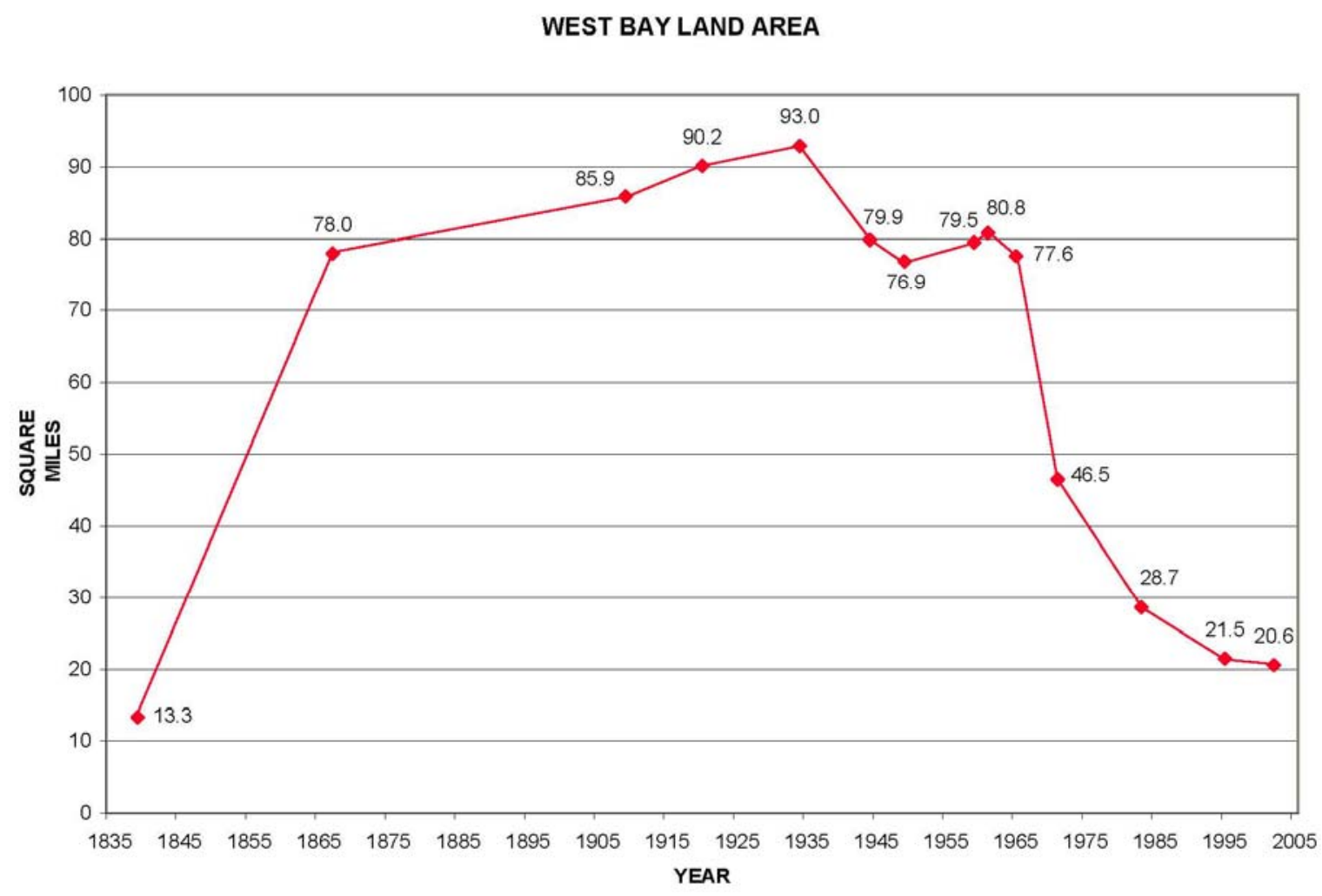

Figure 1-8. Land Extent in the West Bay Subdelta Complex

(Coleman, 2006)

Venice, LA and three were between Venice and Head of Passes. All locations were below the terminus of the mainline Mississippi River flood protection levee system which is at approximately River Mile 44 AHP on the east bank (Bohemia) and River Mile 10.5 AHP (Venice) on the west bank. Diversion structures and associated channels above the terminus of the levee system would require relocations of existing infrastructure such as highways, railroads, levees, drainage canals, and businesses and residences in many areas.

After a rigorous screening process, the West Bay and the Delta National Wildlife Refuge diversion sites were chosen as part of the tentatively selected plan in the draft LLMC study, because of their relatively low site development costs; their lack of potential impacts to active oyster producing areas; and the existing deteriorated condition (nearly all shallow, open water) in 
their receiving areas. The next design consideration after site location was diversion flow capacity. The upper flow limit was considered to be the maximum amount of water that could be diverted above Head of Passes without significantly impacting the Corps' ability to maintain the navigation channel in Southwest Pass. Engineering design criteria developed by the New Orleans District's senior hydrologists limited the maximum diversion at any one location to about $30 \%$ of the river's median discharge. This amounts to a maximum permissible design diversion of approximately $100,000 \mathrm{ft}^{3} / \mathrm{s}\left(2800 \mathrm{~m}^{3} / \mathrm{s}\right)$ when the total discharge of the river measured at Tarbert Landing, Mississippi, is about 380,000 $\mathrm{ft}^{3} / \mathrm{s}\left(3000 \mathrm{~m}^{3} / \mathrm{s}\right)$. The consensus was also that one diversion of this capacity would have more of a potential to progressively capture more and more of river flow over time, creating an unintended avulsion. Therefore, it was decided to study the feasibility of two 50,000 $\mathrm{ft}^{3} / \mathrm{s}\left(1400 \mathrm{~m}^{3} / \mathrm{s}\right)$ diversions, one at West Bay and one at Delta National Wildlife Refuge. Ultimately, the West Bay site was chosen as the most favorable because of its proximity to a large open water area unencumbered by landowners, wildlife management areas, oil and gas facilities, etc. (USACE, 2001).

\subsection{CWPPRA Restoration Project}

The Coastal Wetlands Planning, Protection, and Restoration Act (CWPPRA) was enacted by the U.S. Congress on November 29, 1990. This act directed the formation of the Louisiana Coastal Wetlands Conservation and Restoration Task Force, charged with developing a long term Restoration Plan for Louisiana's coastal wetlands. The Task Force submitted its first annual Priority Project List (PPL) to Congress in November of 1991. As part of the first PPL, the Mississippi River Sediment Diversion at West Bay was approved for planning, design, and construction funding and was sponsored by the Louisiana Department of Natural Resources (LDNR) and the U.S. Army Corps of Engineers (USACE). 


\subsubsection{Project Goals and Objectives}

The main goal set forth in the CWPPRA project monitoring plan was to create, nourish, and maintain 9,831 ac (3,978 ha) of emergent marsh within the project area over the 20 year project life by enhancing the natural process of delta growth and through the beneficial placement of material dredged during construction and maintenance (LDNR, 2003). It is predicted that this will result in tidal flats that are intermittently flooded and suitable for marsh development. The project could also have beneficial secondary impacts of erosion control, increased fisheries productivity, and wildlife benefits (USACE 2001).

\subsubsection{Project Features}

Project features consist of a large-scale, uncontrolled sediment diversion channel into West Bay through the west bank (right descending bank) of the Mississippi River at mile 4.7 Above Head of Passes (AHP). The diversion channel was planned to be constructed in two phases: 1) construction of an interim diversion channel to accommodate a discharge of 20,000 $\mathrm{ft}^{3} / \mathrm{s}\left(570 \mathrm{~m}^{3} / \mathrm{s}\right)$ at the $50 \%$ duration stage of the River, and 2) modification of the interim diversion channel design to accommodate $50,000 \mathrm{ft}^{3} / \mathrm{s}\left(1400 \mathrm{~m}^{3} / \mathrm{s}\right)$ at the $50 \%$ duration stage of the River immediately upon completion of a period of intensive monitoring of diversion operations.

Contingency plans for closing the diversion conveyance channel would be implemented if hydrographic monitoring of the Mississippi River navigation channel indicated any of the following: migration of the river thalweg toward the diversion channel, substantial shoaling in the navigation channel downstream of the diversion, or saltwater intrusion impacts on drinking water intakes upstream (USACE, 2001). There is also a concern, based on modeling studies, that the diversion may induce shoaling just upstream of the diversion in the Pilottown Anchorage 
Area. Therefore contingencies were included in the project budget to maintenance dredge this area over the 20-year project life.

During construction of the conveyance channel, a small amount of riverbank and adjacent wetlands were excavated. This material was used beneficially by pumping the hydraulically dredged sediment into the project area creating immediate subaerial habitat. West Bay has long been used as a beneficial use disposal site by the USACE for dredging of the Mississippi River navigation channel. These past disposal sites are depicted along with the CWPPRA project features in Figure 1-9.

\subsubsection{Design Considerations}

Once engineering began, design considerations including diversion angle (angle of the channel with respect to the bank and river thalweg) and sediment retention were contemplated. The angle of deflection between the direction of flow in the parent channel and the direction of flow in the diversion channel is generally called the "angle of diversion.” Egyptian engineers who studied the effect of angle of diversion called it the "angle of twist." They attached considerable importance to its effect on the amount of sediment directed into a diversion channel (USACE, 2001).

Any diversion at an angle with the flow in the parent channel becomes, in effect, a curve with curvature opposite to that of the parent channel. The higher velocity surface water requires a greater force to turn it than does the slower moving water near the stream bed. Consequently, the surface water, because of its higher momentum, tends to continue with the parent stream. Conversely, the slower moving water near the bed, that carries the greater concentration of sediment, tends to flow into the diversion channel. Therefore, the diversion channel receives the sweep of the bed load, which flows from the outside to the inside of a curve. For any angle of 


\section{WEST BAY PROJECT FEATURES}

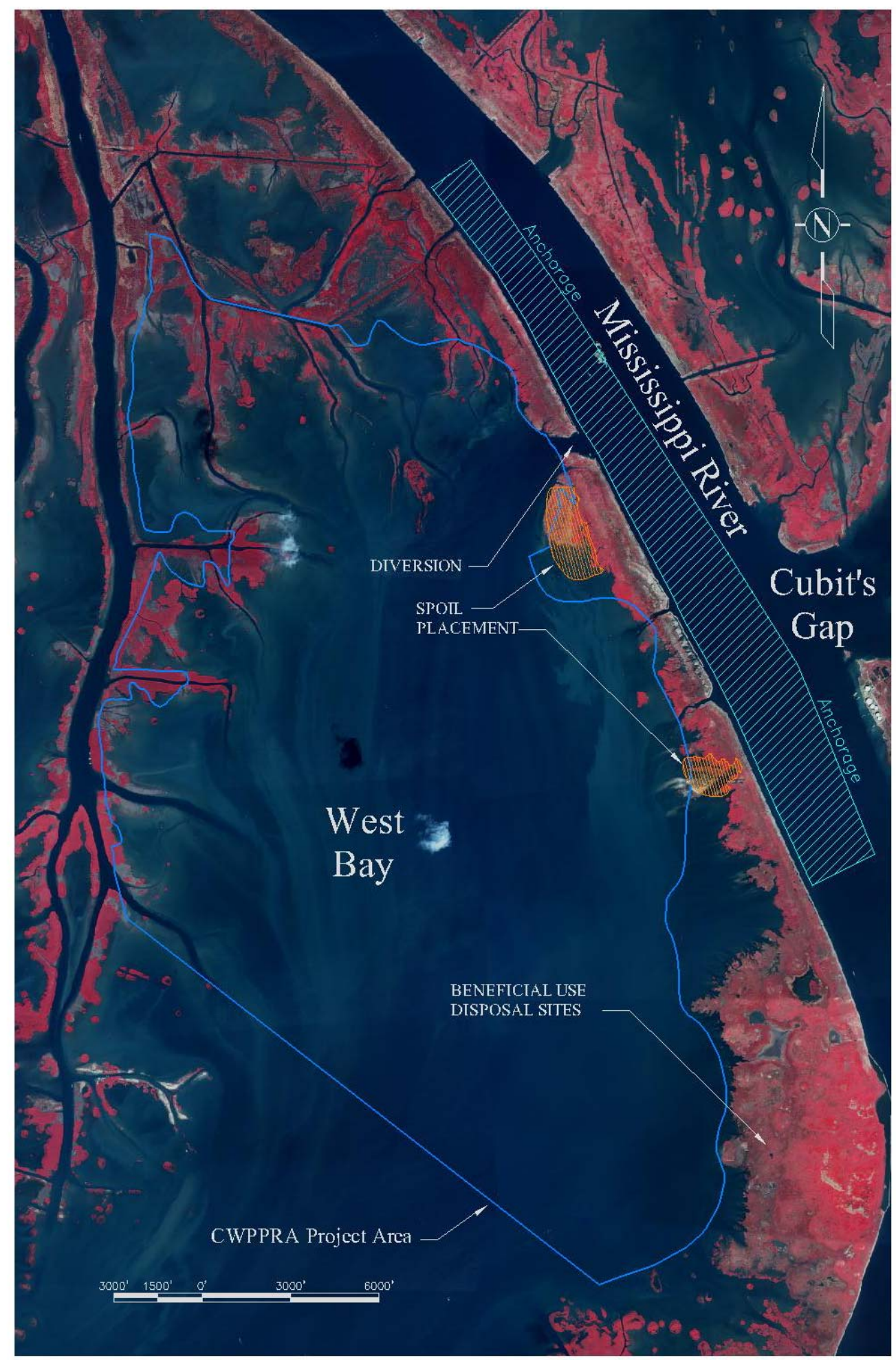

Figure 1-9. Project features of the West Bay CWPPRA Project MR-03 (2005 Aerial) 
diversion, the diversion takeoff is, in effect, on the inside of the curve created by the diversion (USACE, 2001).

Results of model studies by H. Bulle (1926), and independently by a A. Schoklitsch (1937), attempted to give some of the parameters necessary to determine the optimum angle of diversion. However, it was found that there is no one optimum angle. This angle varies with the position of the diversion to the discharge in the stream. The optimal angle also varies with the position of the diversion intake in a stream bed. The best solution to the problem is to select the diversion angle by model study for the dominant diversion ratio, or for the condition that produces the maximum bed-load discharge. In the absence of a model study, $120^{\circ}$, measured from the direction of the flow in the parent stream, is usually acceptable as the angle of the diversion channel that produces maximum bed load diversion (USACE, 2001).

The LLMC study also proposed the idea of improving sediment diversion performance through the use of Sediment Retention Enhancement Devices (SRED's). Two different SRED designs were evaluated as part of the study: an earthen dike with low-level weirs located at $1,000 \mathrm{ft}(305 \mathrm{~m})$ intervals, and a truck tire/filter screen system. Engineering evaluation of the two alternatives indicated that both were equally effective in promoting sediment retention. However, the truck tire/filter screen system was eliminated because its total cost over the life of the project was significantly higher.

After the earthen dike conceptual design shown in Figures 1-10 and 1-11 was chosen, the SRED's were evaluated to determine their cost effectiveness as part of the marsh development. Incremental cost increases of constructing the SRED's were compared in against predicted increases in marsh acreage. Generally, this preliminary evaluation showed that the benefits of implementing the SRED's outweighed the costs. 


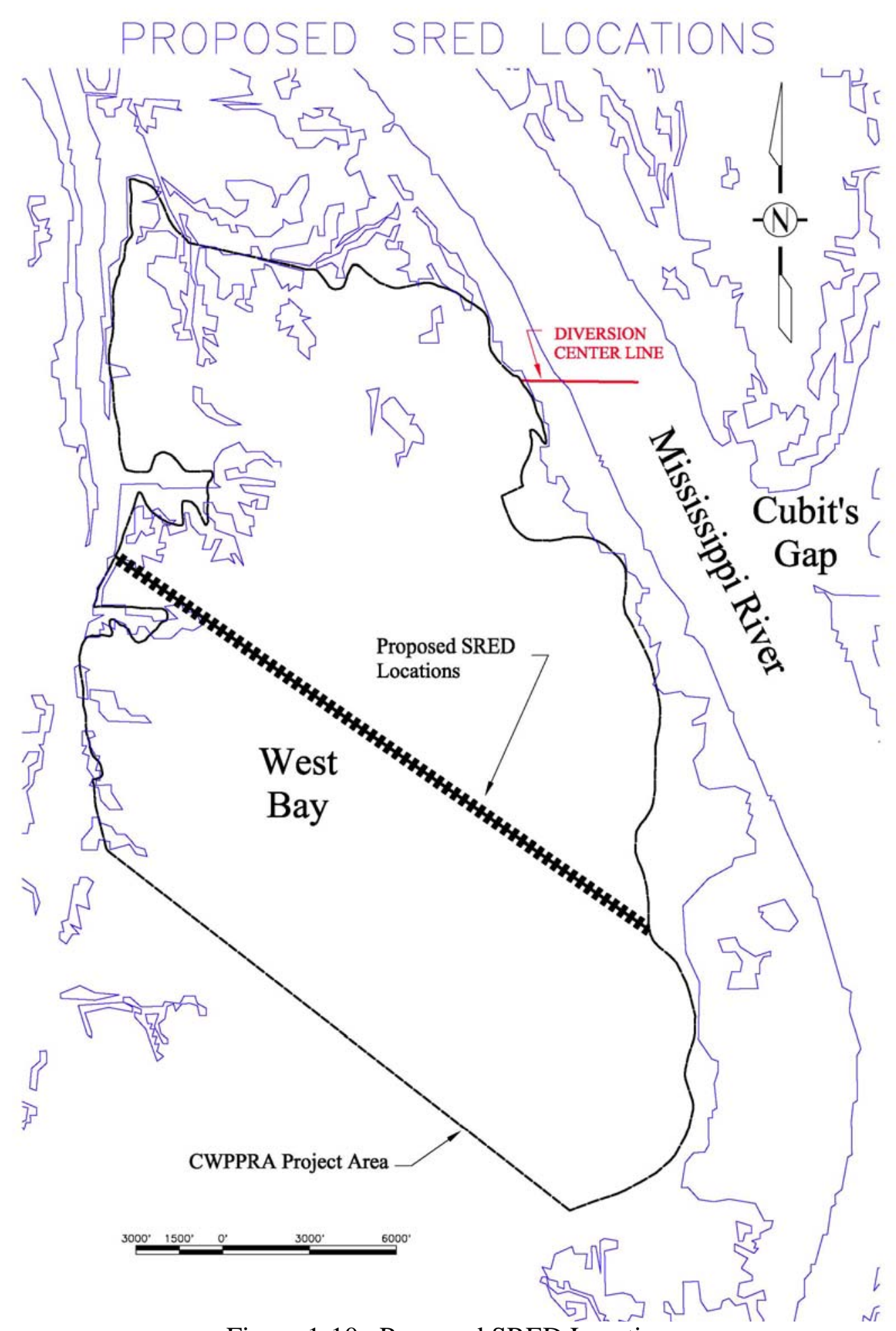

Figure 1-10. Proposed SRED Locations

(Modified from USACE, 2001) 


\section{EARTHEN SRED}

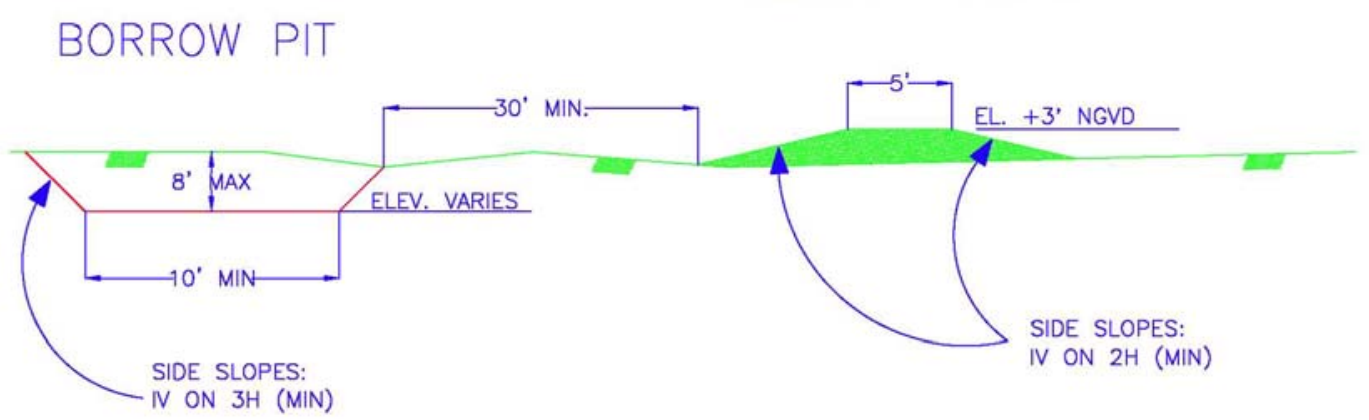

Figure 1-11. Proposed SRED Design

(Modified from USACE, 2001)

The 9,831 ac (3978 ha) of marsh estimated to be created by this sediment diversion was calculated without SRED's during the twenty-year project life. The need for construction SRED's will be determined from results of monitoring during the initial 20,000 $\mathrm{ft}^{3} / \mathrm{s}\left(570 \mathrm{~m}^{3} / \mathrm{s}\right.$ ) diversion phase. If the need for the SRED's is realized, their location will be determined to best enhance marsh building (USACE, 2001). Sediment deposition patterns observed as part of this study may offer some insight that could be used in this determination.

\subsubsection{Project Construction}

Because of navigation concerns and land rights negotiations, the project was not constructed until late 2003. In November of 2003 dredging of the diversion channel was completed and sediment-laden Mississippi River water once again flowed into West Bay. To achieve the initial design flow rate, the diversion was dredged $25 \mathrm{ft}$ (7.6 m) deep and $195 \mathrm{ft}$ (60 m) wide. This was accomplished with a hydraulic cutterhead dredging operation and pipeline transport system. Prior to commencing dredging operations, a small segment of rock-dike bank protection had to be removed. Figure 1-12 shows a theoretical cross section of the diversion cut through the rock dike and natural levee. Figure 1-13 also shows the theoretical dredge cut in a 
profile view. Figure 1-14 is a photograph of the construction in progress picturing the dredge and looking west into the bay. One of the beneficial use sediment disposal sites is captured in the top left corner of the photo.

\section{FORESHORE DIKE REMOVAL AND DISPOSAL THEORETICAL SECTION}

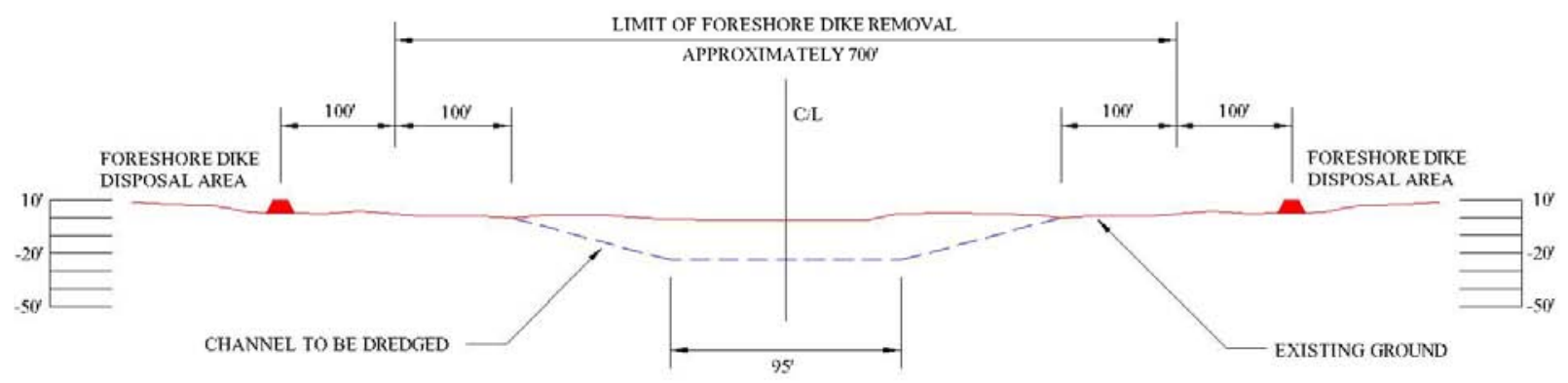

Figure 1-12. West Bay Diversion Theoretical Dredge Cut Section

(modified from USACE, 2003)

\subsubsection{Project Monitoring}

The existing CWPPRA project monitoring plan intends to assess this goal by measuring the project's effects on land/water ratios, bathymetry/topography, and emergent vegetation. No direct measurements or quantitative modeling of sediment flux and fate are included in the CWPPRA plan, and no elevation measurements are scheduled until 2008 (LA DNR, 2003). Diversion flows are currently being collected on a monthly basis and stage both in the river and the receiving basin are being collected continuously. Additionally, elevation surveys were conducted for pre-construction conditions and will be conducted again at years 5, 10, 15, and 20 after construction. Vegetation surveys will also be conducted every five years after construction for the duration of the project.

\subsection{Previous Studies of Engineered Diversions}

Few quantitative dynamical/sedimentological studies have been undertaken to study the 


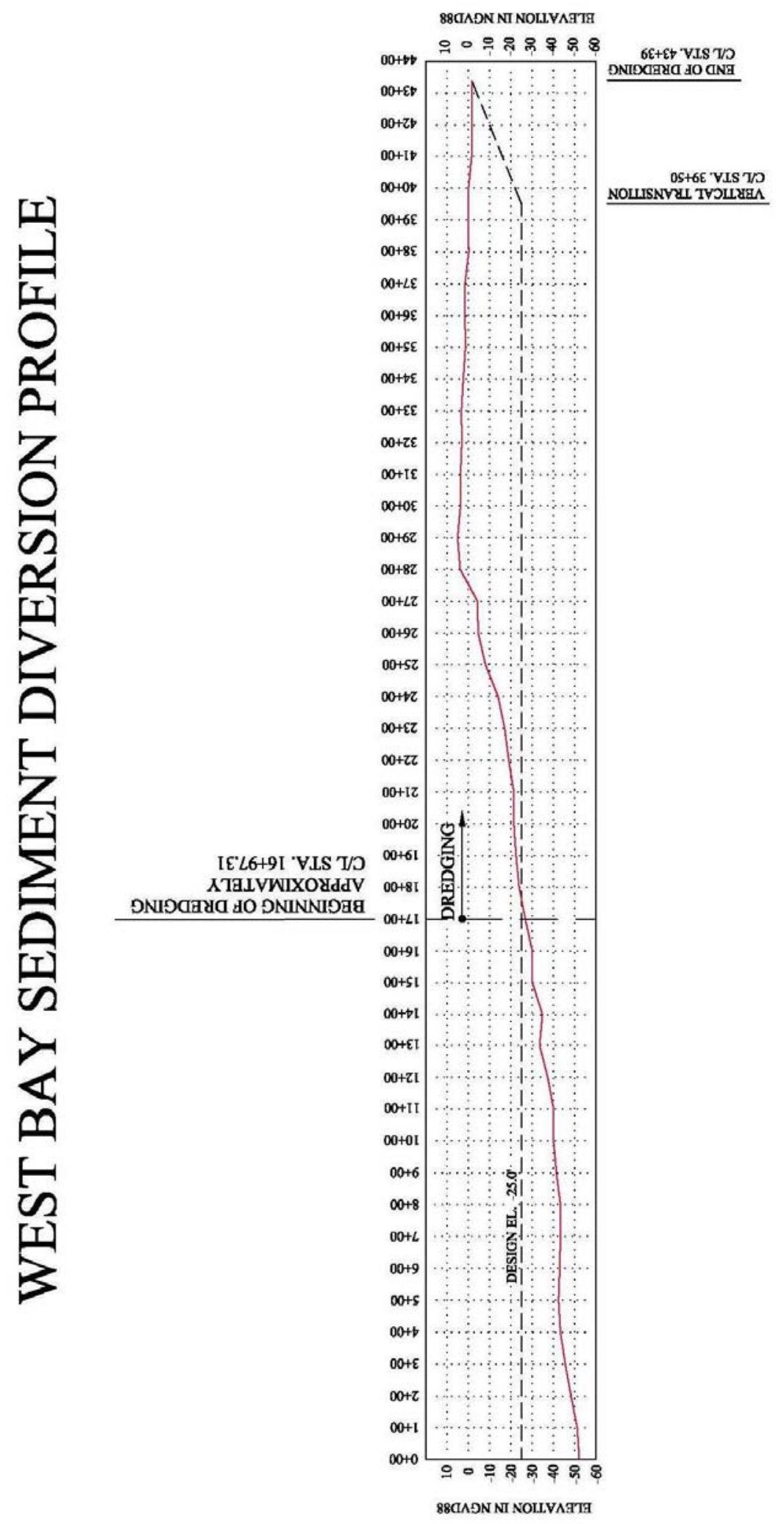

Figure 1-13. West Bay Diversion Theoretical Dredge Cut Profile (modified from USACE, 2003) 


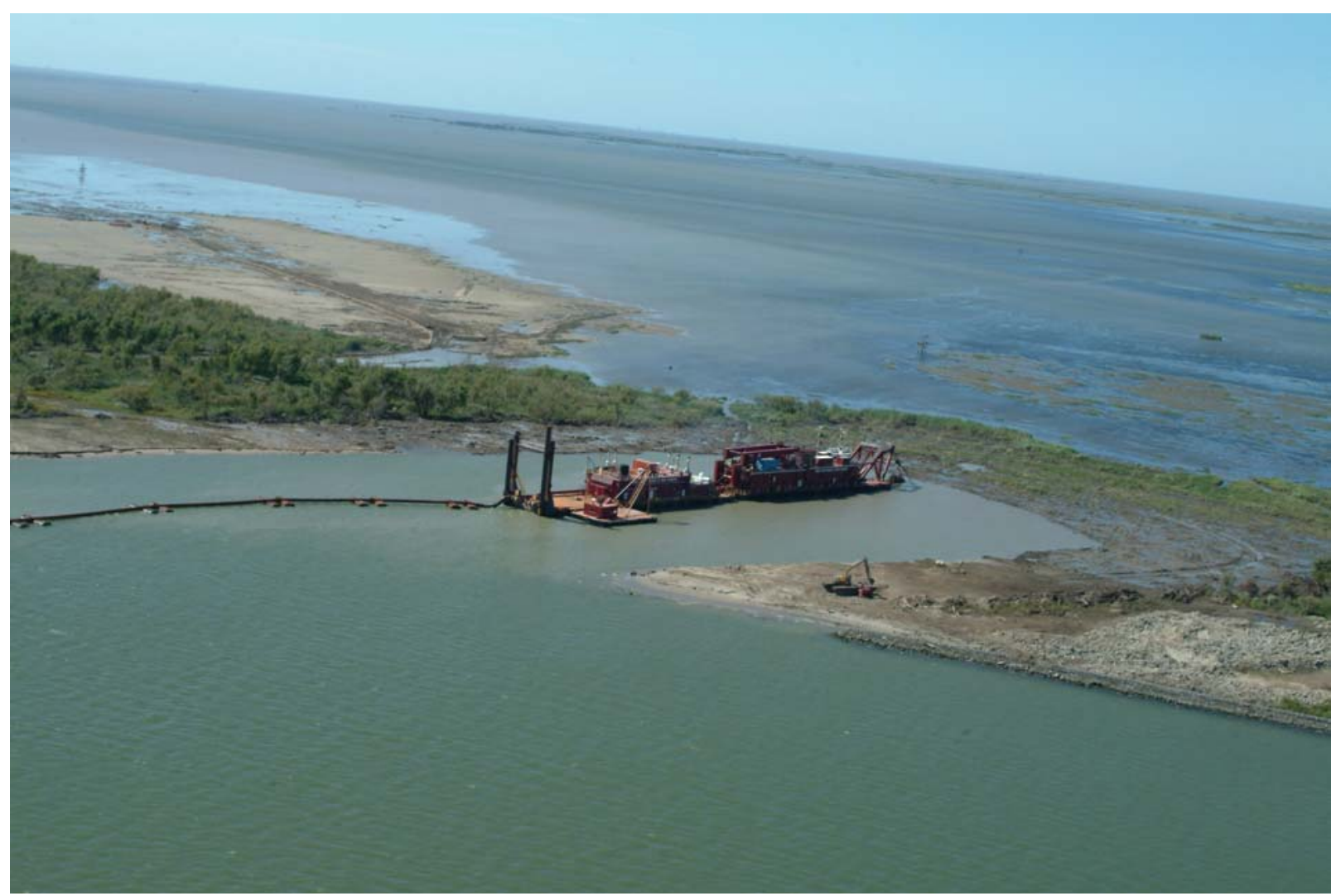

Figure 1-14. West Bay Diversion Under Construction

(Photo taken by USACE, 2003)

hydrodynamic processes that contribute to subdelta formation, even though a clear understanding of these processes is critical to forecasting the sediment retention and ultimate success of the West Bay Diversion, and other similar diversions in the future. Wheelock (2003) documented sediment deposition in association with diversion flow; Snedden et al. (2006) measured sediment flux and deposition vs. rates of relative sea level rise; and Boyer and Turner (1997) demonstrated that crevasse (i.e., diversion) construction can be an economical approach to land building near the river. A number of studies have shown that biogeochemical processes associated with diversion flow can improve river water quality (Lane et al., 2001).

Important lessons have been learned from sediment studies near the Wax Lake Outlet, an engineered diversion of the Atchafalaya River. The Atchafalaya River transports approximately 
$40 \%$ of sediment carried by the Mississippi River; this sediment has been building deltas in Atchafalaya Bay since the early 1970's (Roberts, 1997). Three decades ago, it was predicted that shallow bays near the Atchafalaya River would fill completely with sediment in less than twenty years (Roberts, 1997). Recent studies in the area have shown that strong wave-current regimes driven by cold front passages re-suspend sediment in the bays, and transport sediment onto the open shelf, where it is entrained in coastal currents. Efficiency of sediment bypassing is enhanced because intense wind-driven re-suspension coincides with peak sediment delivery in the Mississippi system (February-March), which actually precedes peak seasonal water discharge (April-May, on average). Sand and some mud remain behind, but most sediment delivered by the Atchafalaya River probably bypasses the bays, and is transported onto the open shelf, where it impacts coastal environments downstream (Roberts, 1997; Allison et al., 2000; Bentley, 2003).

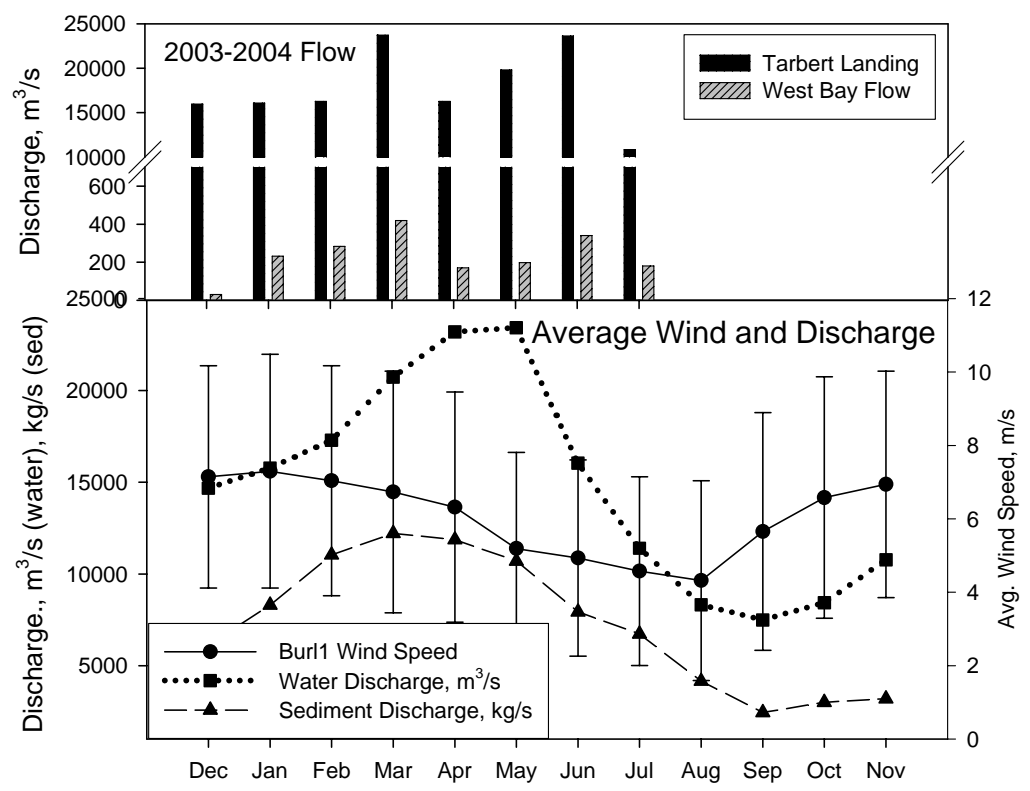

Figure 1-15. Comparison of River Flow, Wind and Sediment Discharge Peaks

Figure 1-15 compares river peak river flows with wind and sediment discharge peaks. The top of the figure displays 2003-2004 flow in the Mississippi River at Tarbert Landing, with 
estimated flow through the West Bay diversion. The bottom of the figure displays monthly wind speed at Southwest Pass (BURL1, mean $\pm 1 \sigma$ ), and average water and sediment discharge at Tarbert Landing. It is important to note that sediment discharge peaks early, when winds remain strong.

The exact balance between sediment retention in the bays and sediment bypassing to the shelf is not known, however. It is likely that identical bypassing processes are/will be active in present and future engineered land-building diversions like West Bay, and a complete quantitative understanding of such processes is essential to predicting the success of such enterprises (and to predicting impacts on down drift coastal environments). Although the work presented herein represents only a small step toward an ability to understand and predict subdelta evolution, these steps should provide important insights applicable to future efforts to manage river sediment and build land, particularly in settings where project design needs to be optimized for maximum sediment retention.

\subsection{Objectives of This Study}

Most coastal restoration efforts are designed to combat natural processes by engineering and constructing dredge and fill projects, shoreline protection projects, or re-planting native vegetation. These types of projects either directly restore lost habitat or protect existing habitat and are fairly predictable. Even hydrologic restoration projects are designed to restore or enhance existing marsh health through controlled diversions. The goal of the West Bay Sediment Diversion is to build land using natural hydraulic and geologic processes which are uncontrolled for this project and difficult to predict.

This study is intended to increase our understanding of sediment delivery by the diversion, sediment retention within the bay and, ultimately, the success of the diversion toward 
building land. Specific objectives are: (1) through hydrographic means, estimate sediment flux into West Bay from the Mississippi River over a two-year period; (2) determine short-term sediment accretion rates and describe seasonal sediment distribution patterns using radiochemical techniques and x-radiographic images of bay bottom samples; (3) estimate sediment retention over two years in West Bay by comparing pre and post-construction bathymetric surveys; and (4) identify coastal processes that may influence the efficiency of sediment retention within the project area by analyzing velocity, salinity, tide, turbidity, and wind data. 


\section{METHODS}

\subsection{Sediment Sampling and Analysis}

\subsection{1 $\quad{ }^{7}$ Be Dating}

Radioisotopes, such as Berillyum-7 ( ${ }^{7} \mathrm{Be}, 1 / 2$-life 53.3 days) can be used to reconstruct the recent sedimentation history of the coastal seabed, particularly in river-influenced settings. In this study, ${ }^{7} \mathrm{Be}$ is used to track sediment flux from the diversion and determine short-term sediment-accumulation rates. ${ }^{7} \mathrm{Be}$ is a naturally occurring radioisotope with a half-life of 53.3 days that is formed in the atmosphere by reactions between cosmic rays and nitrogen and oxygen. Atmospheric fluxes of ${ }^{7}$ Be have been shown to vary spatially with latitude and temporally with rainfall amount (Canuel et al., 1990; Baskaran et al., 1993). In fluvial-marine depositional systems, ${ }^{7}$ Be geochronology is a powerful tool to document and estimate sediment flux and deposition over seasonal timescales (Feng et al., 1999; Sommerfield et al., 1999; Allison et al., 2000; Rotondo and Bentley, 2003; Collis 2006; Palinkas et al., 2005). In fluvial marine systems where the catchment basin is larger than the region receiving sediment, (such as the Mississippi Delta), the cosmogenic, particle-reactive radioisotope ${ }^{7}$ Be can be used as a tracer of sediments recently derived from the fluvial source. Sediments that contain significant ${ }^{7}$ Be must have been deposited within several half-lives of ${ }^{7} \mathrm{Be}$, or $<200$ days, based on its 53-day half life.

\subsubsection{Sediment Collection}

Most of West Bay seabed is subtidal and $<3 \mathrm{ft}$ (1 m) deep, so cores were collected from shallow-draft vessels using pushcores. Coring was coordinated with the hydrographic surveys along established CWPPRA bathymetric survey lines at twenty stations as shown in Figure 2-1. Sample locations were evenly distributed throughout the study area including areas through the center of the bay both near the diversion and in deeper open water areas away from the diversion, 


\section{West Bay Sampling Locations}

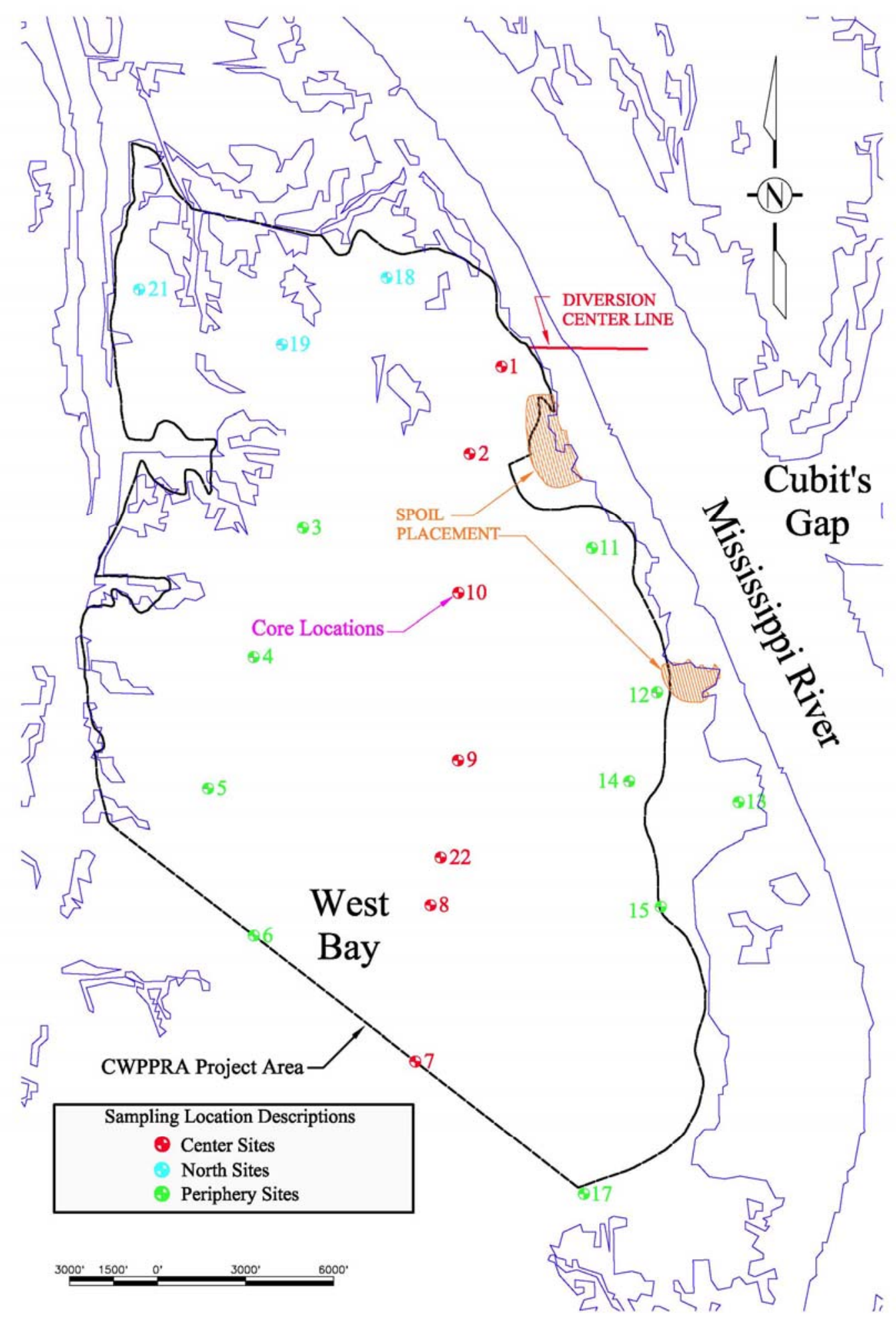

Figure 2-1. West Bay Sediment Sampling Plan 
shallower areas around the periphery of the bay, and semi-enclosed areas north of the diversion with less efficient hydraulic connections to diversion flows.

Samples were collected in four separate events from 2004 to 2006, intended to capture conditions just before and after annual high water. The first sampling event was conducted on March 18-19 (2004) and the second sampling event was conducted on August 23-24 (2004). LDNR provided an airboat and two field personnel at no cost for these efforts. Subsequently, funding was allocated through a grant from the Coastal Restoration and Enhancement through Science and Technology program (CREST) allowing for more robust data collection efforts. Funding for the CREST program is administered by the Louisiana Universities Marine Consortium (LUMCON) using funds provided by the National Ocean Service of the National Oceanic and Atmospheric Administration (NOAA). In the process of securing this funding, no sampling was conducted in the spring of 2005. The next two field collection events were undertaken by LSU CSI researchers and field support staff. Sampling was conducted from a shallow-draft bay boat that could access most sampling locations, with the exception of a semienclosed area that could only be reached by airboat. The third sampling event was conducted on November 3 (2005). It is important to note that this was approximately two months after Hurricane Katrina, which devastated lower Plaquemines Parish making logistics very challenging. The fourth sampling event was conducted on April 12-14 (2006).

Cores were collected using 3" diameter PVC core barrels. Because this study focuses primarily on short-term accumulation rates produced by recent fluvial processes, core barrels were cut in short lengths of approximately $3 \mathrm{ft}(1 \mathrm{~m})$ long. The CSI field staff constructed an efficient self-sealing coring device designed to allow core extraction with minimal effort. The suction head was constructed out of an aluminum billet with a shoulder cut as a bearing surface 
for core insertion. The barrel was sealed to the suction head with hose clamps and tape. Venting of captured air and water was accomplished with eight (8), $1.75 \mathrm{~cm}$ vents that seal with a spring loaded, rubber-faced aluminum plate. Spring tension was adjustable to account for different viscosities of material being vented. When core extraction was initiated, a suction was created to the interior of the core barrel, facilitating removal of the core with minimal material loss. Capping is done once the core was recovered.

X-ray samples were acquired using three-sided Plexiglas trays employing a sliding panel as the fourth side. The tray was initially pushed into the bay floor then the fourth panel was slid into place guided by grooves in the side panels, thereby shearing the sample from the adjacent sediments and enclosing within the tray. The sample was then pulled from the bay floor and capped and sealed for storage and travel. In locations deeper than $3 \mathrm{ft}(1 \mathrm{~m})$ this was accomplished using SCUBA gear. All field studies are further described in Appendix B.

\subsubsection{Laboratory Analyses}

X-radiographic subsamples were imaged soon after collection using a Thales Flashscan digital panel X-ray detector with 14 bit, $127 \mu \mathrm{m}$ pixel resolution. Images were then stored as 16bit TIFF files for subsequent study. Sediment grain size distributions were measured with a Micromeritics Sedigraph 5100 which uses $\mathrm{x}$-rays to sense changing concentrations of fine sediments settling in a suspension with time in accordance with Stoke's Law. Sediment samples were taken from the cores at $2 \mathrm{~cm}$ increments for sedigraph analysis and median grain size values were recorded for each sample. Activities of ${ }^{7} \mathrm{Be}$ were determined by gamma spectroscopy of dried sediment (477.7 $\mathrm{KeV}$ peak for ${ }^{7} \mathrm{Be}$ ) (Sommerfield et al., 1999). The sediment was weighed before and after drying for water content to be used in porosity calculations. A known mass of ground sediment was then placed in a $6 \mathrm{~cm}$ petri dish and sealed. 
The sealed samples were analyzed on a Canberra gamma detector. Beryllium activities were measured in decays per minute per gram of sediment $(\mathrm{dpm} / \mathrm{g})$. The detection limit for a $15 \mathrm{~g}$ sample is approximately $0.2 \mathrm{dpm} / \mathrm{g}$.

\subsubsection{Sediment Accumulation Rates (SAR)}

Changes in sedimentation rates in estuaries provide by far the strongest evidence for the effects of catchment sediment runoff on estuarine systems. Sedimentation rates are measured by calculating the thickness of sediment between dated layers in cores. These SAR are net values because cores integrate the effects of all the processes that influence sedimentation at a given location. At short time scales (ie., seconds-months), sediment may be deposited and then subsequently re-suspended by tidal currents and/or waves. Sediment mixing through physical processes and/or bioturbation can also affect the resolution of sediment dating profiles but these effects reduce as SAR increase (Nittrouer et al., 1984).

The maximum depth of ${ }^{7}$ Be occurrence is a useful indicator of short-term (months) sediment deposition and mixing because of its relatively short half life (53.3 days). Profiles of ${ }^{7}$ Be activity in the seabed were determined for each core sampling station in West Bay for the four sampling events. Beryllium activity at the time of field sampling (A) measured in dpm/g was calculated using the equation:

$$
A=A_{0} e^{-\lambda t}
$$

where $A_{0}$ is the activity at the time of detection, $\lambda=0.013 \mathrm{~d}^{-1}$ is the decay constant for ${ }^{7} \mathrm{Be}$, and $\mathrm{t}$ is the time elapsed between sample collection and detection. This equation may also be used to describe theoretical activity vs. depth profiles of ${ }^{7} \mathrm{Be}$ for steady-state sedimentation conditions 
where $\mathrm{A}_{0}$ is activity at initial deposition on the bay bottom or zero depth zero, $\mathrm{z}_{0}$, A is activity at penetration depth, $\mathrm{z}(\mathrm{cm})$, and $\mathrm{t}$ is the time elapsed between initial deposition on the bay bottom and ${ }^{7}$ Be being covered to penetration depth, z. Equation 1 can be re-written as:

$$
\mathrm{A}=\mathrm{A}_{0} \mathrm{e}^{-\lambda z / \mathrm{S}}
$$

where $\mathrm{S}$ is the sediment deposition or SAR in $\mathrm{cm} / \mathrm{yr}$. Therefore $\mathrm{S}$ can be calculated by the following equation (Nittrouer et al., 1979):

$$
\mathrm{S}=-\lambda \mathrm{z} / \ln \left(\mathrm{A} / \mathrm{A}_{0}\right)
$$

Because the slope of the natural $\log$ of measured ${ }^{7}$ Be activity vs. depth can be represented as the change in $\ln (\mathrm{A})$ divided by the change in depth $\mathrm{z}$, equation 4 can be derived by substituting the best fit of this linear slope, $\mathrm{m}$ for $\mathrm{z} / \ln \left(\mathrm{A} / \mathrm{A}_{0}\right)$ in equation 3 :

$$
S=-\lambda / m
$$

Best fit lines can be determined using a regression analysis where $\mathrm{R}^{2}$ values indicate "goodness of fit”.

\section{$2.2 \quad$ Elevation Surveys}

A total of three (3) elevation surveys were conducted in the West Bay project area. The first survey was conducted under the direction of LDNR in January and February of 2003, prior to the opening of the diversion in November of 2003. The survey lines established in the 2003 
pre-construction survey were then partially re-surveyed by LSU CSI in November 2005 and again in April 2006.

\subsubsection{Pre-Construction Survey}

As part of the West Bay CWPPRA project MR-03, LDNR hired Morris P. Hebert Inc. $(\mathrm{MPH})$ to perform an elevation survey within the project area to establish preconstruction conditions. The West Bay GPS survey consisted of establishing two (2) top-security monuments, MR-03-SM-01 and MR-03-SM-02, as part of DNR's Secondary GPS Network to be used as horizontal and vertical control for the elevations surveys. The field survey work commenced on January 21, 2003 and was completed on February 13, 2003.

Four (4) published National Geodetic Survey (NGS) High Accuracy Reference Network (HARN) Monuments which are part of the Louisiana Coastal Zone Primary GPS Network were utilized to establish the two (2) new secondary monuments for this survey. All survey monuments were referenced to the Lambert Conformal Conic Projection, Louisiana State Plane Coordinate System South Zone, the North American Datum of 1983 (NAD83), and the North American Vertical Datum of 1988 (NAVD88) modeled to Geoid 99. The newly established monuments consist of multiple four (4) foot lengths of 9/16” diameter stainless steel rods installed by driving to refusal. The monuments are encased in a six (6) foot long, 6" diameter, PVC pipe with cap. The pipe is filled with sand and held in place by concrete. MPH prepared a summary sheet of pertinent benchmark information for each monument installed, which are included in Appendix C. Each summary sheet includes a vicinity map, a description of the monument and its location, photographs of the monument, and a listing of the adjusted monument position in geodetic and Louisiana State Plane coordinates, and the adjusted elevation in the NAVD 88 Datum. 
Seventeen lines were surveyed using Real-Time Kinematic (RTK) GPS equipment. The survey lines were run in a northwest/southeast direction across the open water area in the sediment-receiving bay. For the first $5000 \mathrm{ft}(1525 \mathrm{~m})$ from the mouth of the diversion the lines were surveyed at $1000 \mathrm{ft}(305 \mathrm{~m})$ intervals. The remaining lines were surveyed at $1500 \mathrm{ft}$ (475 m) intervals with the southernmost line being the southern project boundary. Elevations are recorded at $200 \mathrm{ft}(60 \mathrm{~m})$ intervals along each cross section and at every prominent change in elevation of $0.3 \mathrm{ft}(0.1 \mathrm{~m})$ or more. Each cross section line terminates on land with the final elevation point collected approximately $50 \mathrm{ft}$ (15.2 m) from the water's edge (MPH, 2003). Preconstruction survey lines and benchmark locations are shown in Figure 2-2.

\subsubsection{Post-Construction Surveys}

Post-construction surveys were conducted by LSU CSI in November 2005 and April 2006. Lacking topographic land surveying equipment and expertise, CSI was only able to resurvey the water-based portions of the previously established CWPPRA survey lines. Bathymetric surveying was conducted using an Odom Hydrographic fathometer with a depthrecording transducer mounted on CSI’s $22 \mathrm{ft}$ Carolina Skiff fiberglass bay boat. The fathometer was interfaced with Wide Area Augmentation System (WAAS) Enabled GPS for position. This vessel was chosen for its capability of running in relatively shallow water, allowing depths to be recorded in as little of $2.0 \mathrm{ft}(0.6 \mathrm{~m})$ of water. In order to correct the bathymetric data for tidal variations, a tide gauge was deployed for the duration of both surveys on an existing piling near the middle of the bay at a location designated as "WB-Tide" (Figure 2-3). An aluminum benchmark was also installed on the piling to reference all bathymetric and tide data. This benchmark was later referenced back to the LDNR secondary benchmark MR-03-SM-02 so all of the elevation data could be presented in the NAVD 88 datum and compared to pre-constructions 


\section{West Bay Survey Tracklines}

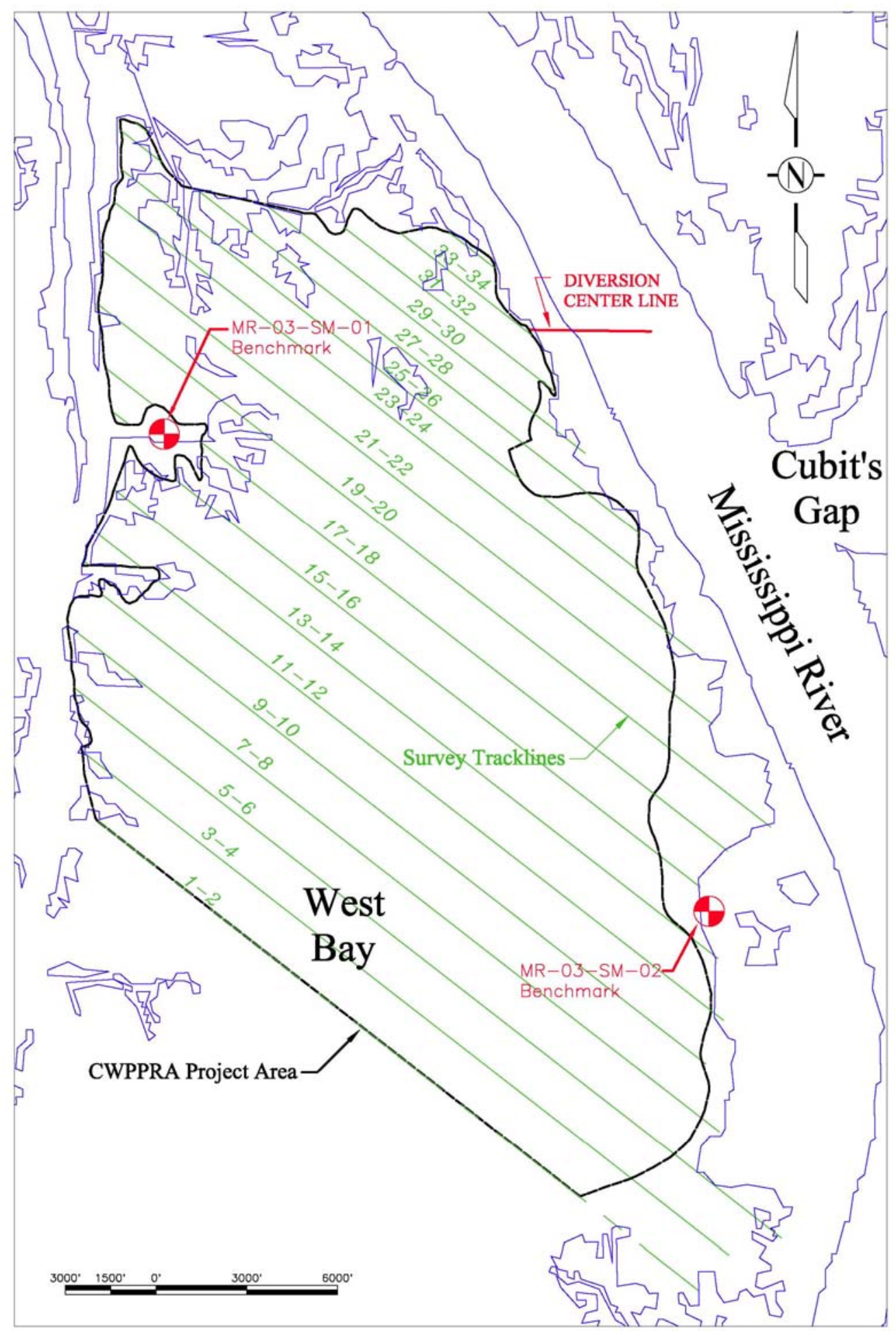

Figure 2-2. West Bay Pre-Construction Survey Layout 
surveys. Additional details regarding the bathymetric survey are presented in Appendix B Field Work Summary, included the survey lines that were run.

\subsection{Flow and Turbidity Measurements}

To appropriately link SAR to the engineered diversion, flow and turbidity studies were undertaken by deploying instrument packages at strategic locations in within the project area. Data collected from this field study was used in tandem with long term flow and sediment concentration data sets from the USACE and U.S. Geological Study (USGS) to broaden the analyses.

\subsubsection{Instrument Deployments}

Instrument packages were deployed at three different locations (Figure 2-3) during the field study from February 8, 2006 to April 14, 2006. The first location, designated as “WB-Cut”, was installed near the south bank of the diversion channel about midway into the cut. At this location a mounting platform had to be constructed for instrument installation. The water depth at the time of platform construction was measured at $12.5 \mathrm{ft}(3.8 \mathrm{~m})$. The instrument platform was constructed using three aluminum core tubes of 4" diameter installed in the seabed using a vibracore adaptor. After the three main legs of the platform were installed several cross-brace boards were installed between the verticals for stability. The instruments to be mounted on the platform were a Nortek Aquadopp Acoustic Doppler Current Profiler (ADCP) and an YSI 6600 sonde. The Nortek was placed a height of $6.0 \mathrm{ft}(1.8 \mathrm{~m})$ from the seabed looking out across the channel to the north. It was also set to collect velocity data at 30 minute intervals averaged over 2 minutes using 5 second bursts. The YSI sonde was mounted with the pressure sensor $7.2 \mathrm{ft}$ (2.2 $\mathrm{m})$ above the bottom. The conductivity and temperature from the sonde were set at $6.8 \mathrm{ft}$ (2.1 $\mathrm{m})$ and the turbidity Optical Backscatter (OBS) sensor at $6.5 \mathrm{ft}(2.0 \mathrm{~m})$ above the bottom. 


\section{West Bay Instrument Locations}

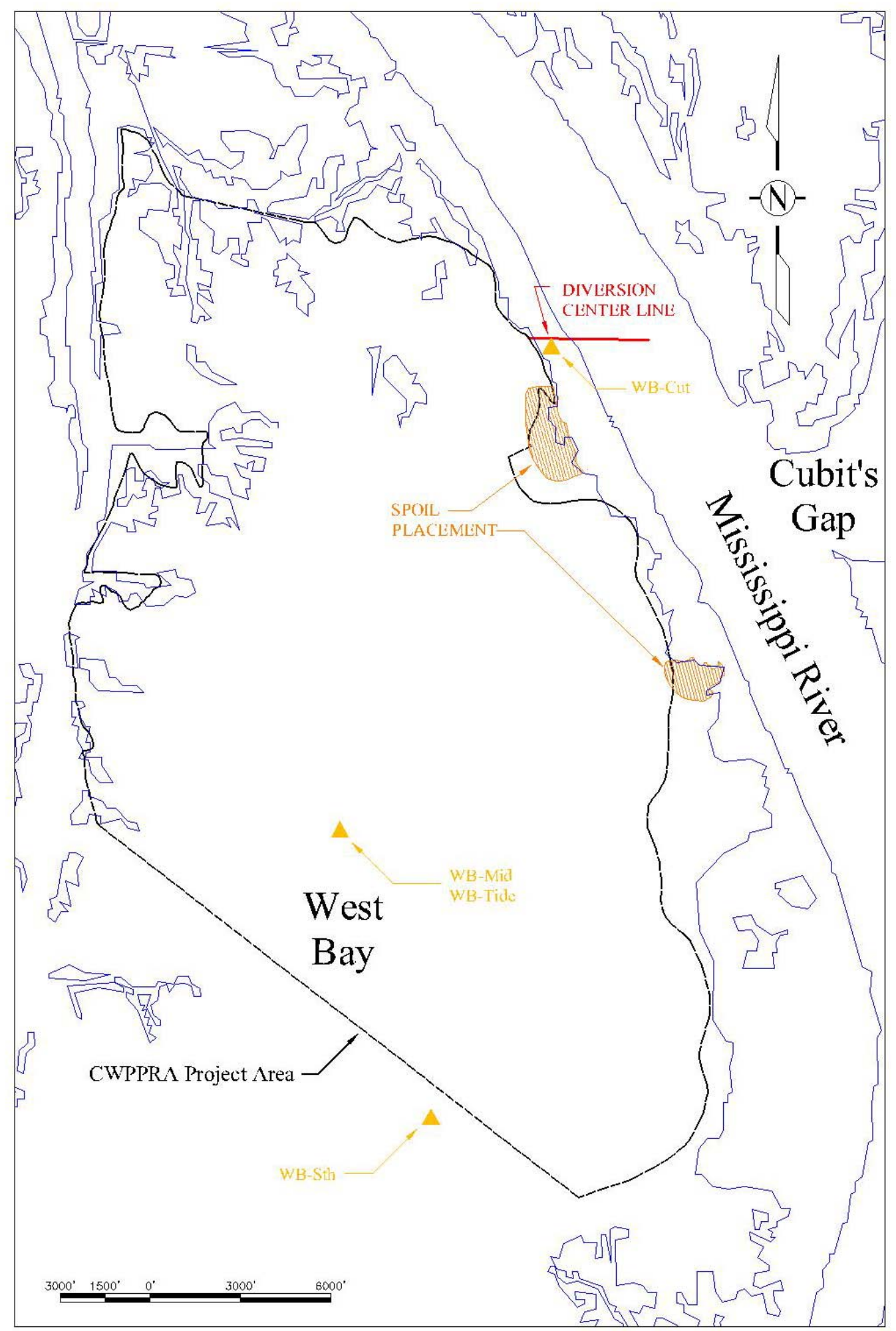

Figure 2-3. West Bay Instrument Locations 
The instruments installed at WB-Cut were left to collect data for one month. The flow data collected at this location was limited considering the diversion is over $200 \mathrm{ft}$ (60 m) wide. The Nortek ADCP measured velocities up to $17.2 \mathrm{ft}(5.23 \mathrm{~m})$ away from the instrument. Therefore, it was decided to collect simultaneous velocity measurements at various locations and depths in the cut to further characterize flows over a detailed channel cross section which could be related back to corresponding Nortek velocities. This was accomplished by boat mounting an RDI Workhorse ADCP looking downward and anchoring at five different locations, WB\#1 WB\#5, shown on Figure 2-4. The boat mounted ADCP survey was conducted on March 7, 2006 just prior to relocating the semi-permanent instrument package to the mid-bay location.

\section{West Bay Instrument Locations at the Diversion Cut}

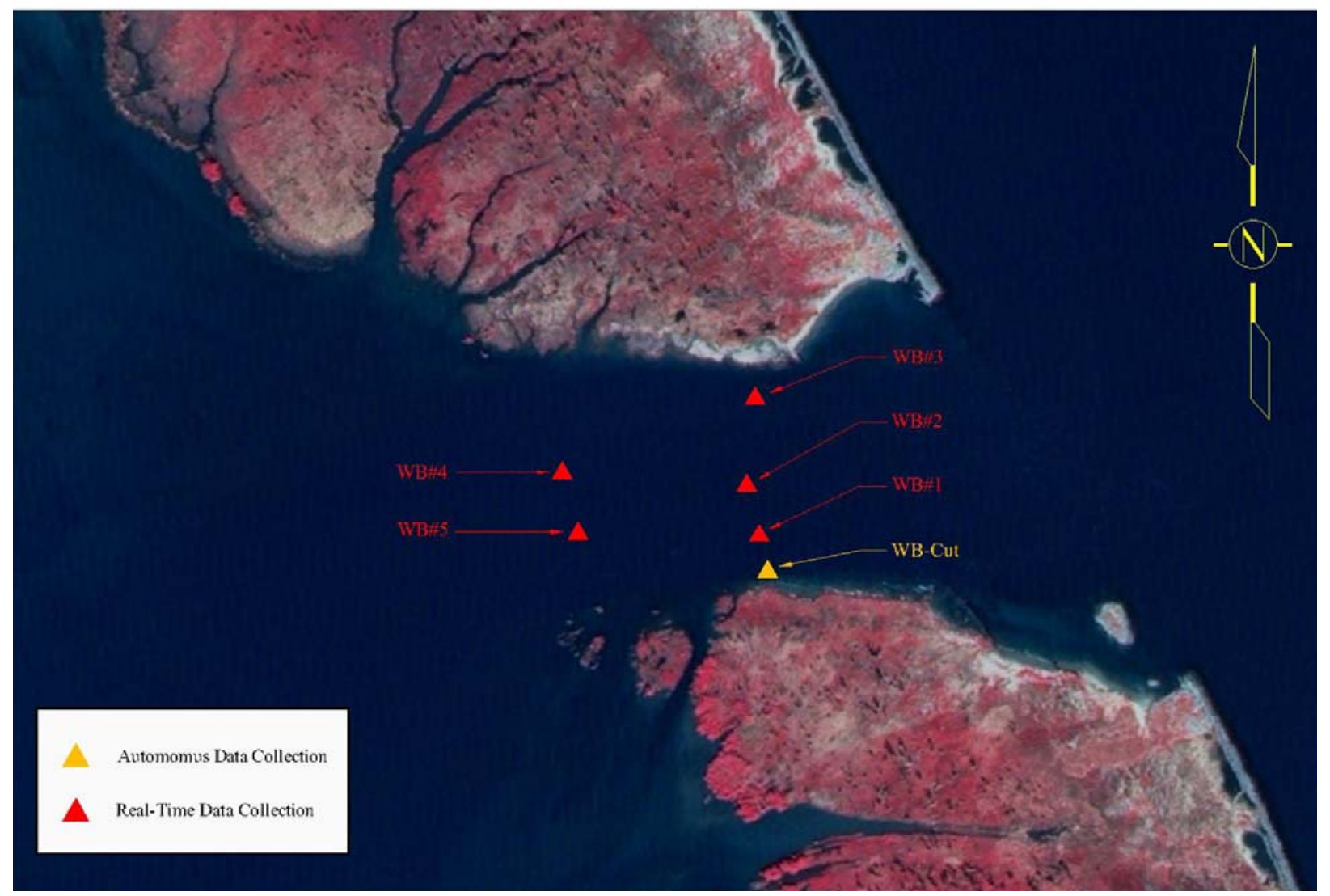

Figure 2-4. ADCP Survey Locations at West Bay Diversion Cut 
After the ADCP Survey on March 7, 2006, the instruments on the deployment platform in the diversion were removed from the mount and the data was downloaded and the battery replaced. The instruments were then relocated to an existing piling at the site previously used for the tide measurements during the first bathymetric survey in November 2005. The designation of the mid-bay instrument location is "WB-Mid". The changes made to the configuration of the Nortek consisted of orienting the sensor head downward, mounted at a height of $4.9 \mathrm{ft}(1.5 \mathrm{~m})$ from the bottom. It was also set to collect velocity data at 30 minute intervals averaged over 2 minutes using 0.5 second bursts. Wave data was collected at 1 hour intervals averaged over 17 minutes using 0.5 second bursts. The YSI sonde was mounted with the pressure sensor $2.6 \mathrm{ft}$ $(0.8 \mathrm{~m})$ above the bottom with the turbidity OBS sensor at $2.0 \mathrm{ft}(0.6 \mathrm{~m})$ above the bottom. The water depth at the time of deployment was $6.2 \mathrm{ft}(1.9 \mathrm{~m})$.

A crew from CSI returned to the site on March 21, 2006 with the intent of relocating the instruments to the south side of the bay at a site on an existing oilfield platform designated as "WB-Sth". The data from the Nortek instrument indicated that the battery only provided power for data collection for approximately 8 days. The YSI 6600 sonde was downloaded to the field computer. The sea state became too rough to safely deploy the Nortek current meter and the YSI sonde. These instruments were relocated back to the WB-Mid site with the YSI pressure sensor $2.5 \mathrm{ft}(0.8 \mathrm{~m})$ off the bottom and the Nortek $4.9 \mathrm{ft}(1.5 \mathrm{~m})$ from the bottom. The YSI 6600 sonde and the Nortek Aquadopp ADCP were removed from the mid-bay site on April 14, 2006. Additional details regarding the field instrumentation study are included in Appendix B - Field Work Summary.

\subsubsection{Long-Term Measurements}

As part of the monitoring program for the MR-03 CWPPRA project the USACE collects 
monthly river flows at Venice, LA, just above the diversion, and in the diversion cut itself. These flows have been measured using a boat mounted ADCP once a month since the opening of the diversion in November 2003. Much longer-term monthly flow and sediment concentration measurements have also been taken for years at Tarbert Landing, located at River Mile 306.3 above Head of Passes near the Old River Control Structure. These records are maintained by the USGS. Additional long-term sediment concentration data was obtained near Belle Chase, LA. These data sets will be compared to the more refined short-term flow and turbidity study conducted by CSI and used in combination to assess sediment flux in the diversion. 


\section{RESULTS}

\subsection{Sedimentary Processes}

Sedimentary processes in West Bay were analyzed using a number of techniques for the data collected during the study period. ${ }^{7}$ Be data were assessed by calculating total inventories and graphing activity profiles. These profiles were in turn used to generate Sediment Accumulation Rates (SAR) and also compared against x-radiograph images to aid in data interpolation.

\subsection{1 $\quad{ }^{7}$ Be Inventories}

As discussed in Section 2.1.4, Beryllium activity at the time of field sampling is measured in decays per minute per gram of sediment (dpm/g). ${ }^{7}$ Be activity can also be reported on a volumetric basis in $\mathrm{dpm} / \mathrm{cm}^{3}$, calculated as the product of the ${ }^{7}$ Be activity, the solids-volume fraction (1-porosity), and the average grain density of the sediment $\left(2.65 \mathrm{~g} / \mathrm{cm}^{3}\right)$. Total inventories were then calculated by integrating volumetric ${ }^{7} \mathrm{Be}$ activity with respect to total core depth for each sampling event resulting in units of $\mathrm{dpm} / \mathrm{cm}^{2}$. Table 3-1 presents the total inventories calculated for each sediment core for each sampling event. Site locations are shown in Figure 2-1 and were categorized by proximity to diversion. Figures 3-1 through 3-7 present bar graphs of total inventories separated by sampling event for representative sites from each category. The results will be used to analyze seasonal and spatial depositional patterns.

\subsection{2 $\quad{ }^{7}$ Be Activity Profiles and X-radiographs}

${ }^{7} \mathrm{Be}$ inventories discussed in the previous section are an indication of overall activities at each sampling location but do not clearly illustrate how the activities change with depth. The activity profiles shown herein were used to determine depth of ${ }^{7}$ Be penetration which is useful in analyzing the $\mathrm{x}$-radiographs also presented in this section. 
Table 3-1. Sediment Core ${ }^{7}$ Be Inventories $\left(\mathrm{dpm} / \mathrm{cm}^{2}\right)$

\begin{tabular}{|c|c|c|c|c|c|c|c|}
\hline Site ID & Spring 04 & Fall 04 & Fall 05 & Spring 06 & Average & Total & Category \\
\hline WB01* & 2.45 & 0.00 & 2.45 & 0.00 & 1.22 & 4.89 & Center \\
\hline WB02 & $\mathrm{NS}^{\star \star}$ & $\mathrm{NS}^{\star \star}$ & 0.49 & 0.33 & 0.41 & 0.82 & Center \\
\hline WB03* & 6.04 & 0.00 & 1.63 & 0.33 & 2.00 & 8.00 & Periphery \\
\hline WB04* & 1.98 & 0.00 & 0.76 & 0.00 & 0.69 & 2.74 & Periphery \\
\hline WB05* & 2.55 & 3.16 & 28.68 & 0.95 & 8.84 & 35.34 & Periphery \\
\hline WB06* & 0.86 & 0.00 & 26.52 & 0.26 & 6.91 & 27.64 & Periphery \\
\hline WB07* & 0.52 & 1.12 & 0.34 & 0.81 & 0.69 & 2.78 & Center \\
\hline WB08 & $\mathrm{NS}^{\star \star}$ & $N S^{\star \star}$ & 1.32 & 0.00 & 0.66 & 1.32 & Center \\
\hline WB09 & $\mathrm{NS}^{* *}$ & $\mathrm{NS}^{* \star}$ & 1.07 & 0.00 & 0.53 & 1.07 & Center \\
\hline WB10* & 0.00 & 1.74 & 0.33 & 3.28 & 1.78 & 5.35 & Center \\
\hline WB11 & 2.09 & 0.17 & NS & NS & 1.13 & 2.27 & Periphery \\
\hline WB12* & 2.96 & 1.40 & 0.64 & 0.56 & 1.39 & 5.56 & Periphery \\
\hline WB13 & 0.00 & 0.00 & $\mathrm{NS}^{\star \star}$ & $\mathrm{NS}^{\star \star}$ & 0.00 & 0.00 & Periphery \\
\hline WB14 & 1.15 & $N S^{\star \star}$ & $\mathrm{NS}^{* \star}$ & $\mathrm{NS}^{* \star}$ & 1.15 & 1.15 & Periphery \\
\hline WB15* & 1.38 & 0.50 & 0.48 & 0.00 & 0.59 & 2.35 & Periphery \\
\hline WB17 & 0.00 & 0.00 & $N S^{\star \star}$ & 1.00 & 0.33 & 1.00 & Periphery \\
\hline WB18 & 0.00 & 0.00 & $\mathrm{NS}^{\star \star}$ & $\mathrm{NS}^{\star \star}$ & 0.00 & 0.00 & North \\
\hline WB19 & 1.47 & 0.00 & $\mathrm{NS}^{* \star}$ & $\mathrm{NS}^{\star \star}$ & 0.73 & 1.47 & North \\
\hline WB21 & 1.92 & 0.33 & $\mathrm{NS}^{* \star}$ & $\mathrm{NS}^{\star \star}$ & 1.13 & 2.25 & North \\
\hline WB22 & 0.76 & 2.26 & $\mathrm{NS}^{* *}$ & $N S^{\star *}$ & 1.51 & 3.02 & Center \\
\hline
\end{tabular}

*Sites were sampled at each collection event.

${ }^{\star *} \mathrm{NS}=$ Not sampled 

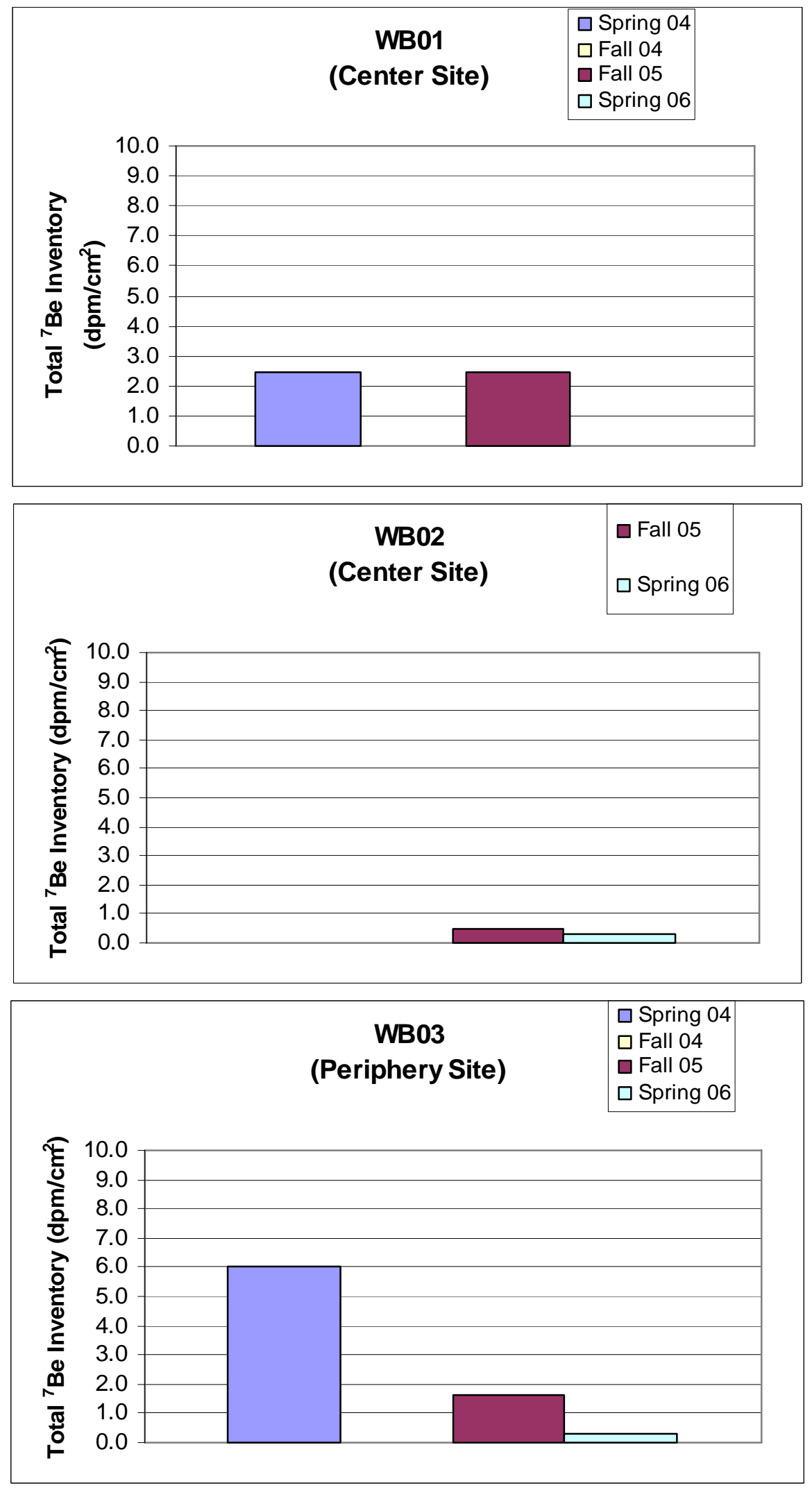

Figure 3-1. ${ }^{7}$ Be Inventory Bar Graphs for Sites WB01 - WB03 

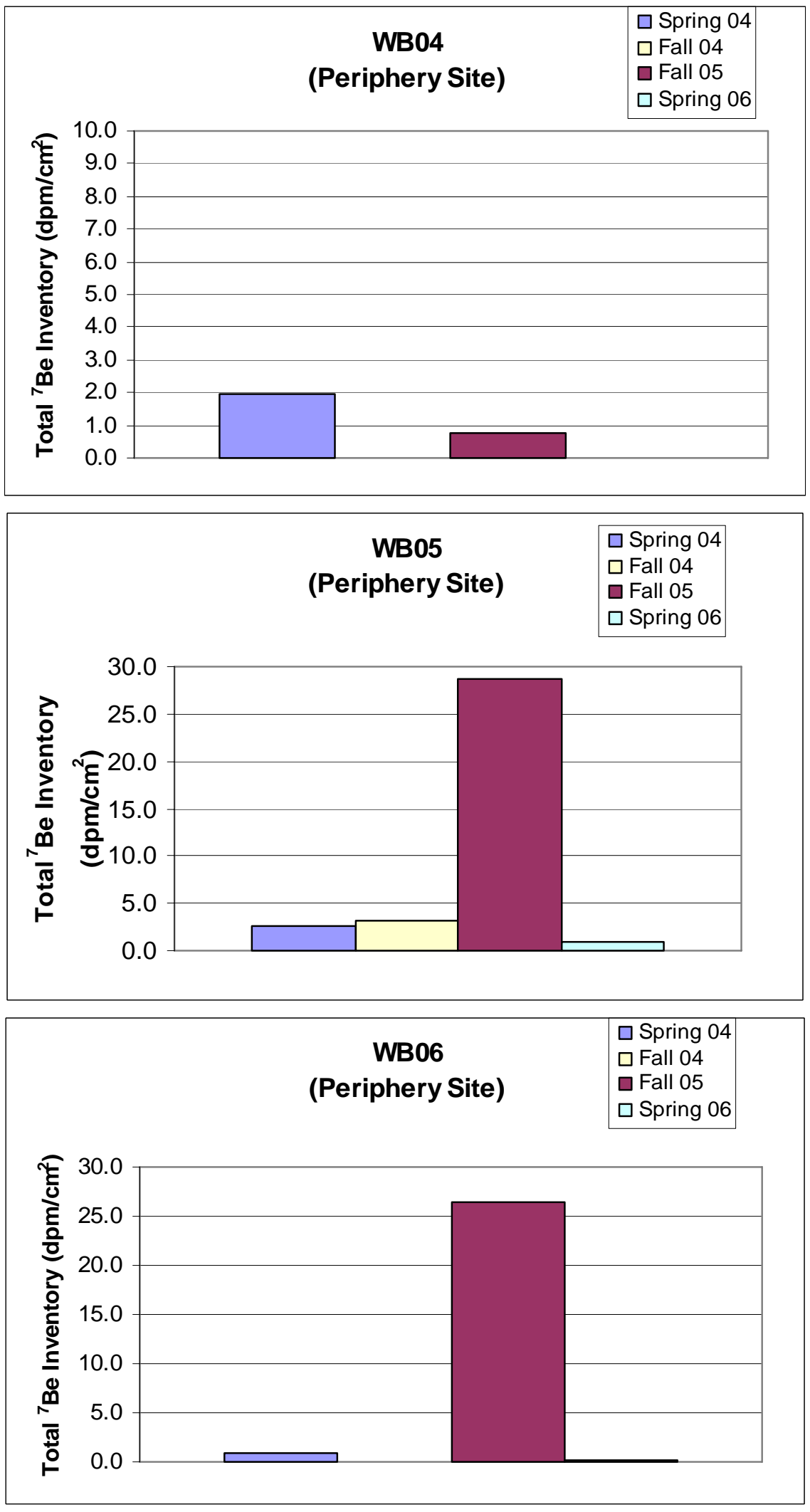

Figure 3-2. ${ }^{7}$ Be Inventory Bar Graphs for Sites WB03 - WB06 

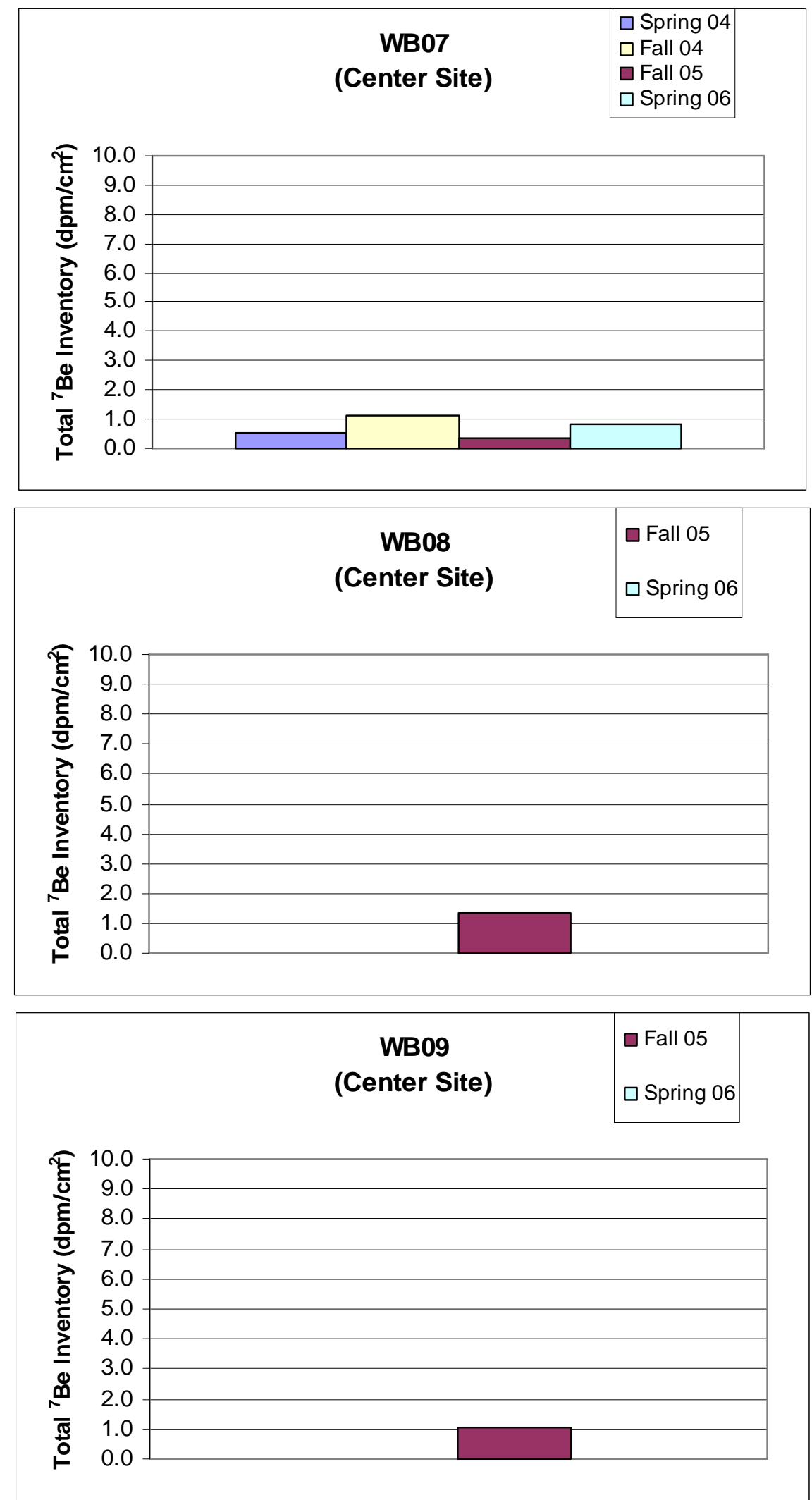

Figure 3-3. ${ }^{7}$ Be Inventory Bar Graphs for Sites WB07 - WB09 

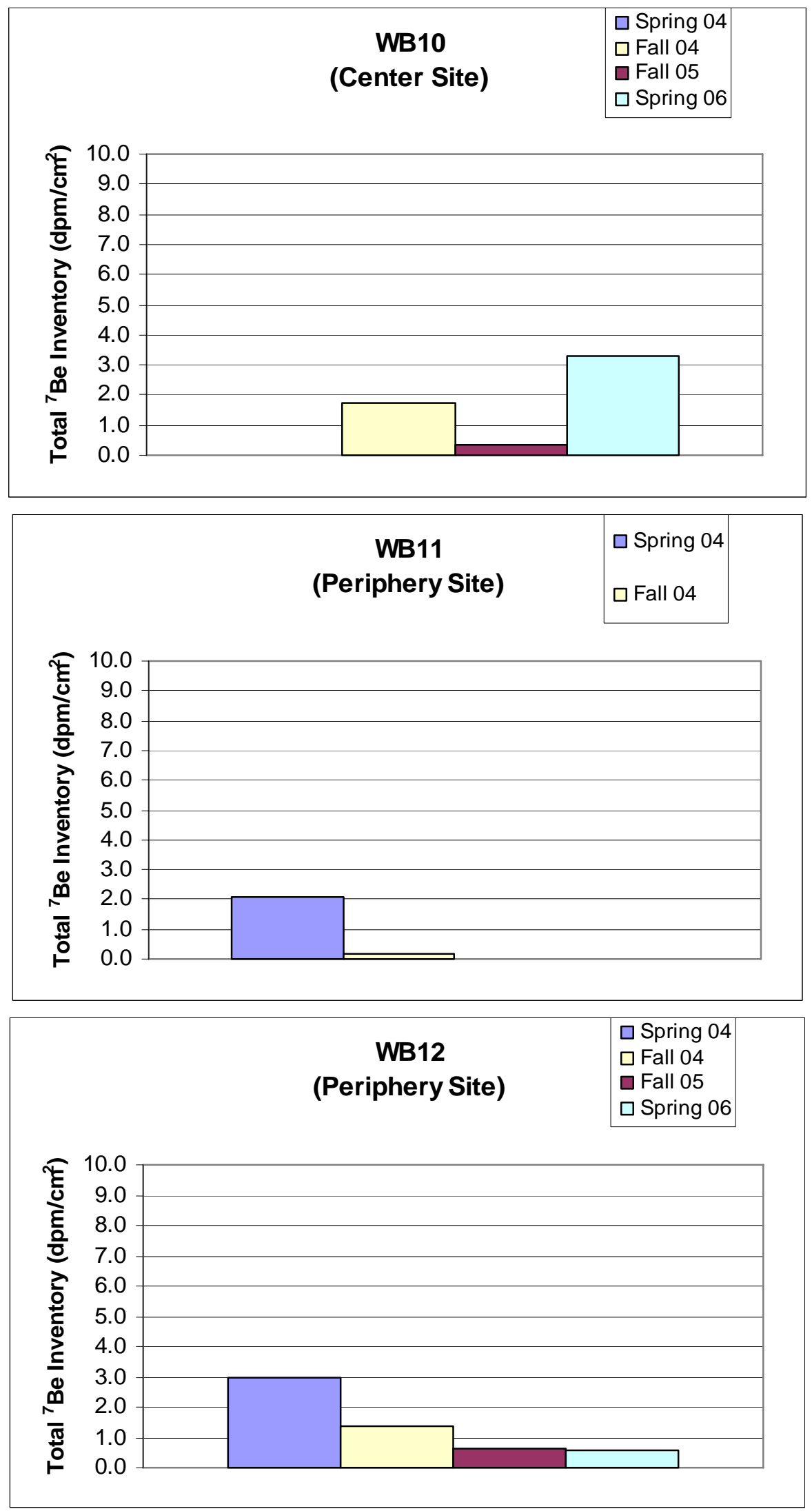

Figure 3-4. ${ }^{7}$ Be Inventory Bar Graphs for Sites WB10 - WB12 

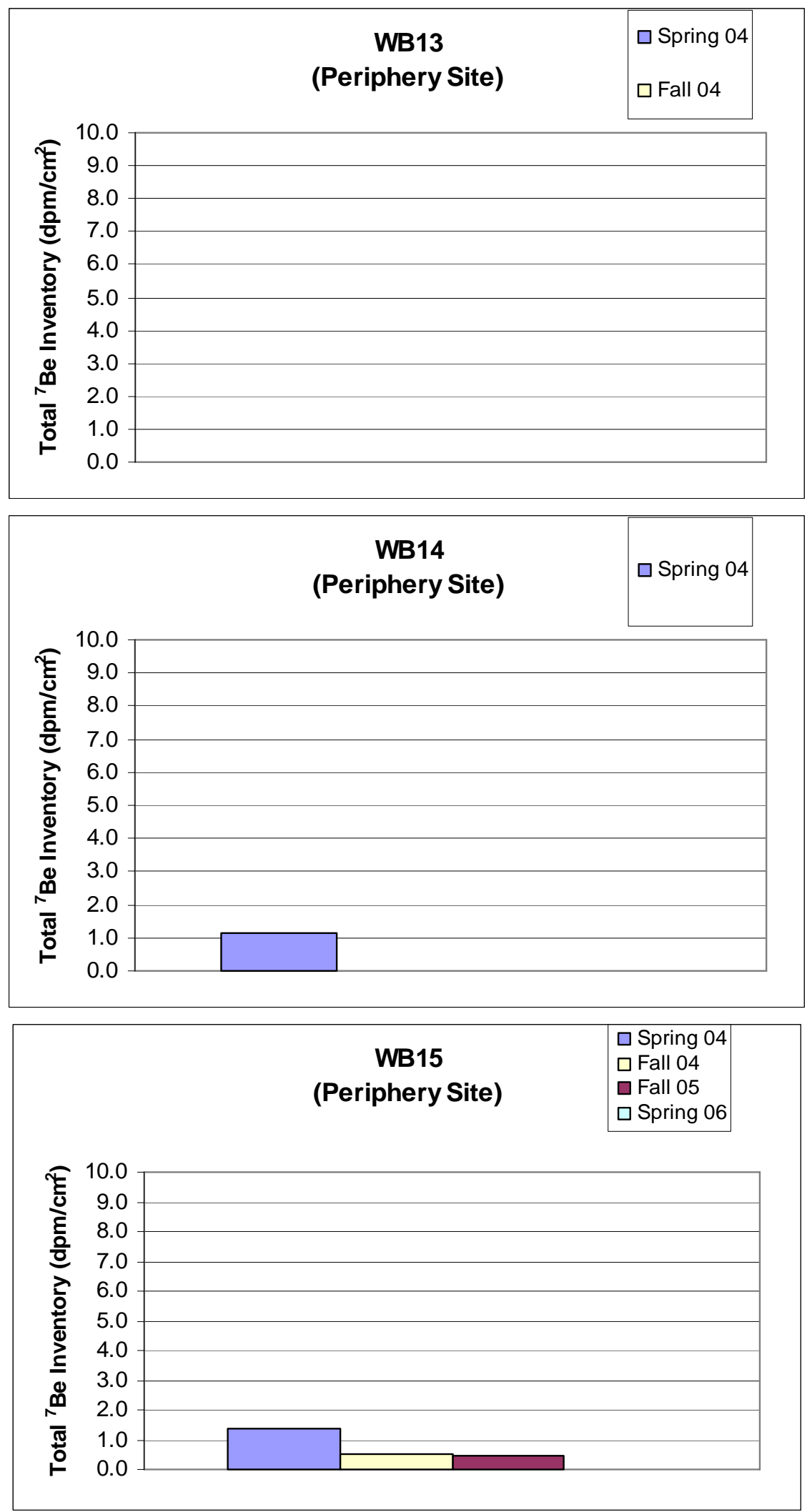

Figure 3-5. ${ }^{7}$ Be Inventory Bar Graphs for Sites WB13 - WB15 

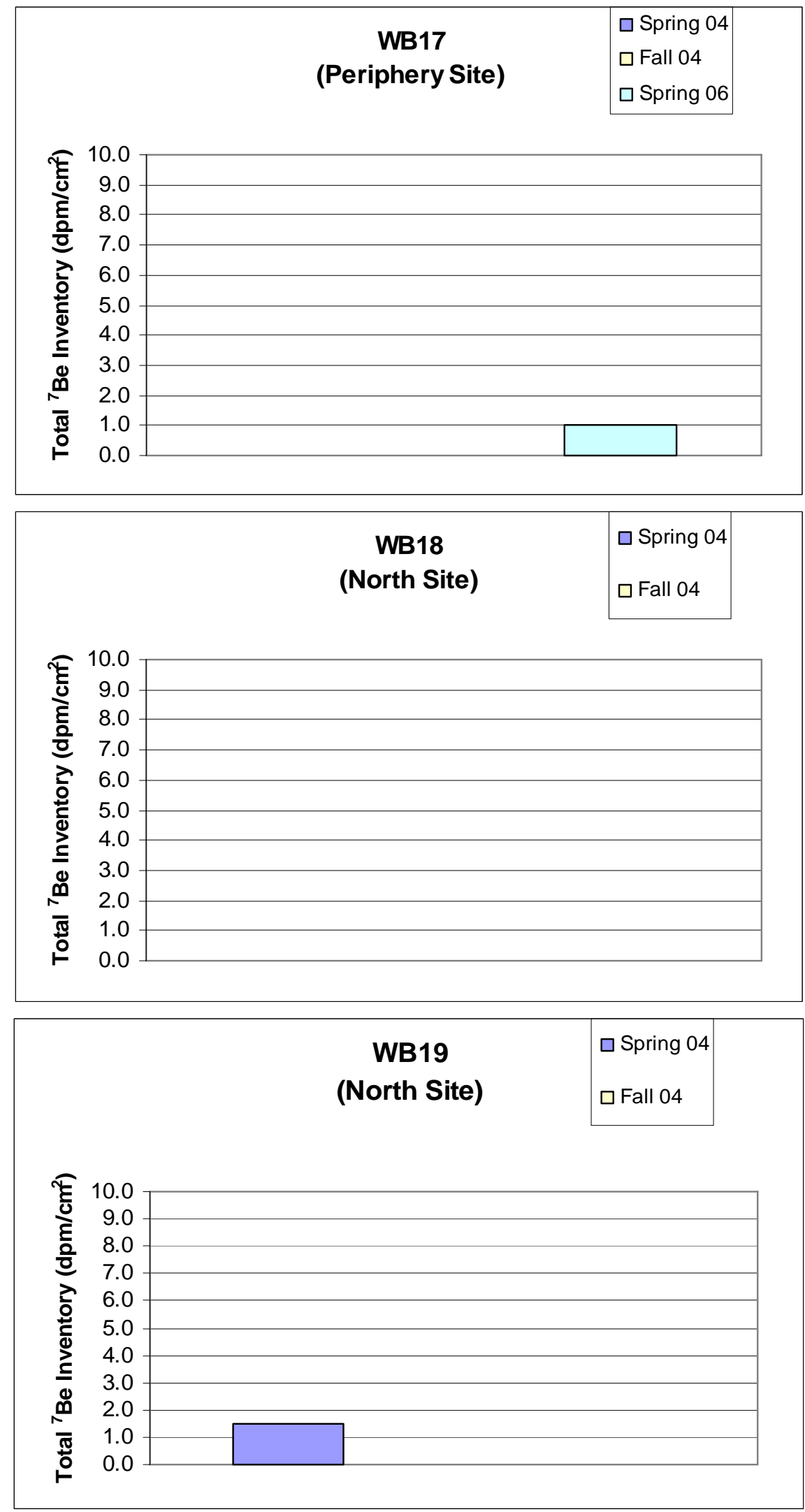

Figure 3-6. ${ }^{7}$ Be Inventory Bar Graphs for Sites WB17 - WB19 

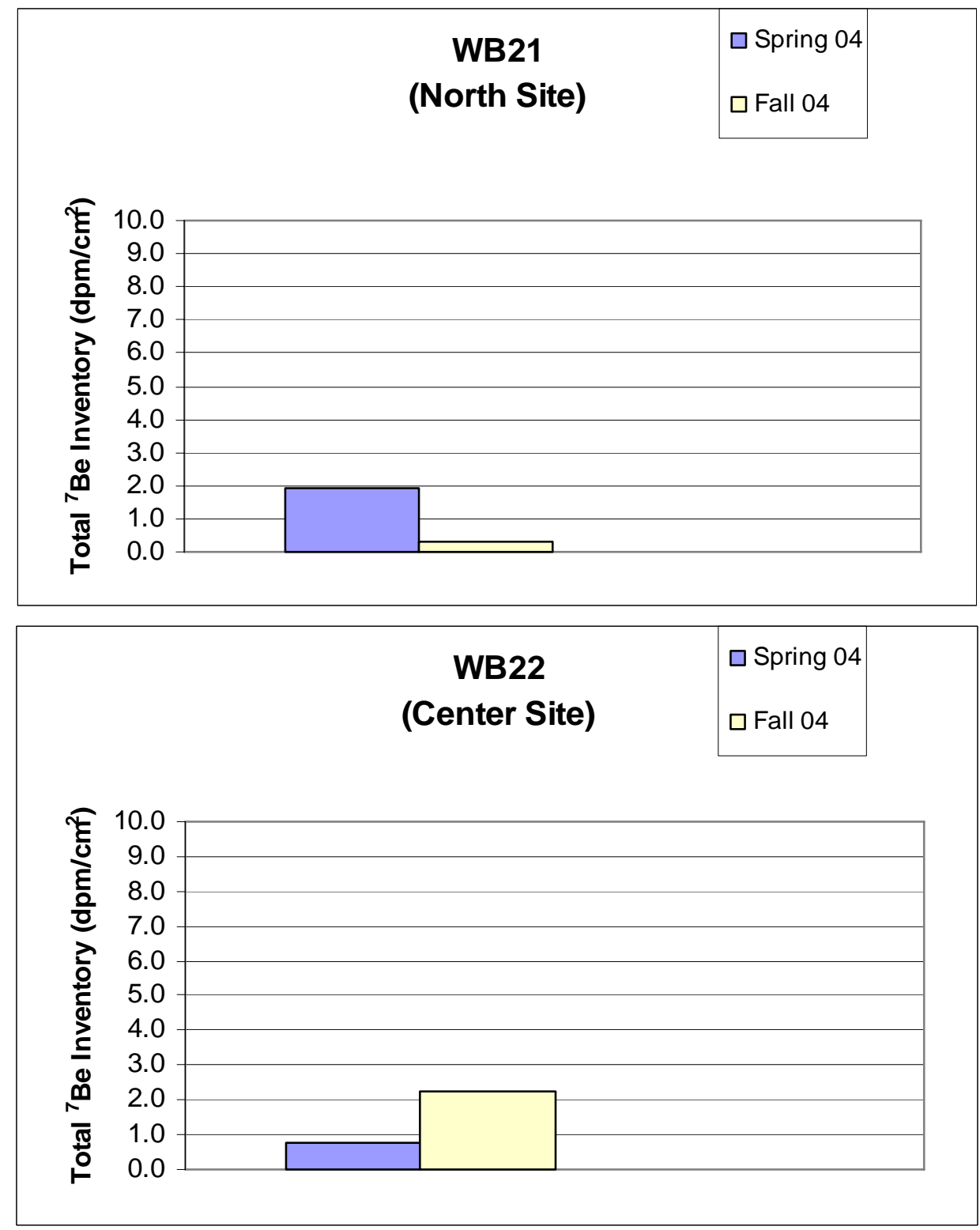

Figure 3-7. ${ }^{7}$ Be Inventory Bar Graphs for Sites WB21 \& WB22 
X-radiograph images of sediment samples were taken and analyzed for the purpose of interpreting sedimentary processes (i.e. contrasting light and dark shading in the x-radiographs can be produced by differences in sediment, grain size, organic content, and moisture contents). All x-radiographs are shown with denotations of ${ }^{7}$ Be penetration depths and interpreted event layers. In general, dark shades indicated finer grain sizes and/or higher water content, whereas lighter shades indicate coarser sediment and/or lower water content.

Figures 3-8 through 3-22 depict ${ }^{7}$ Be activity profiles in dpm/g and corresponding $\mathrm{x}$ radiograph images for individual sampling stations. The activity profiles consist of ${ }^{7} \mathrm{Be}$ measurements down to $10 \mathrm{~cm}$ and also display the range of error encountered during gamma detection. Notes on each figure describe sediment layering and bed forms seen in the $\mathrm{x}$ radiographs in comparison with ${ }^{7} \mathrm{Be}$ activities and penetration depths. Figures 3-23 and 3-24 depict ${ }^{7}$ Be activity profiles for stations where no $\mathrm{x}$-radiograph samples were collected.

\subsubsection{Grain Size Analyses}

Using methods described in Section 2.1.3, median sediment grain sizes were calculated at $2 \mathrm{~cm}(0.8 \mathrm{in})$ increments for the top $10 \mathrm{~cm}$ (3.9 in) of select cores that were sampled from the project area. Table 3-2 summarizes the cores that were analyzed for sediment grain size and the averages of the median grain sizes for the sea bed surface characterized as the top $10 \mathrm{~cm}$ (3.9 in).

Overall, grain sizes at the sea bed surface can be characterized as fine to medium silts (silts range from $2-62.5 \mu \mathrm{m}$ ). Averages of the median grain sizes were also calculated by sampling event. The average median grain sizes for Spring 2004 and Fall 2004 are 8.84 and 9.64 microns $(\mu \mathrm{m})$, respectively. These values are lower than the Fall 2005 and Spring 2006 values of 22.5 and $15.4 \mu \mathrm{m}$, respectively. 


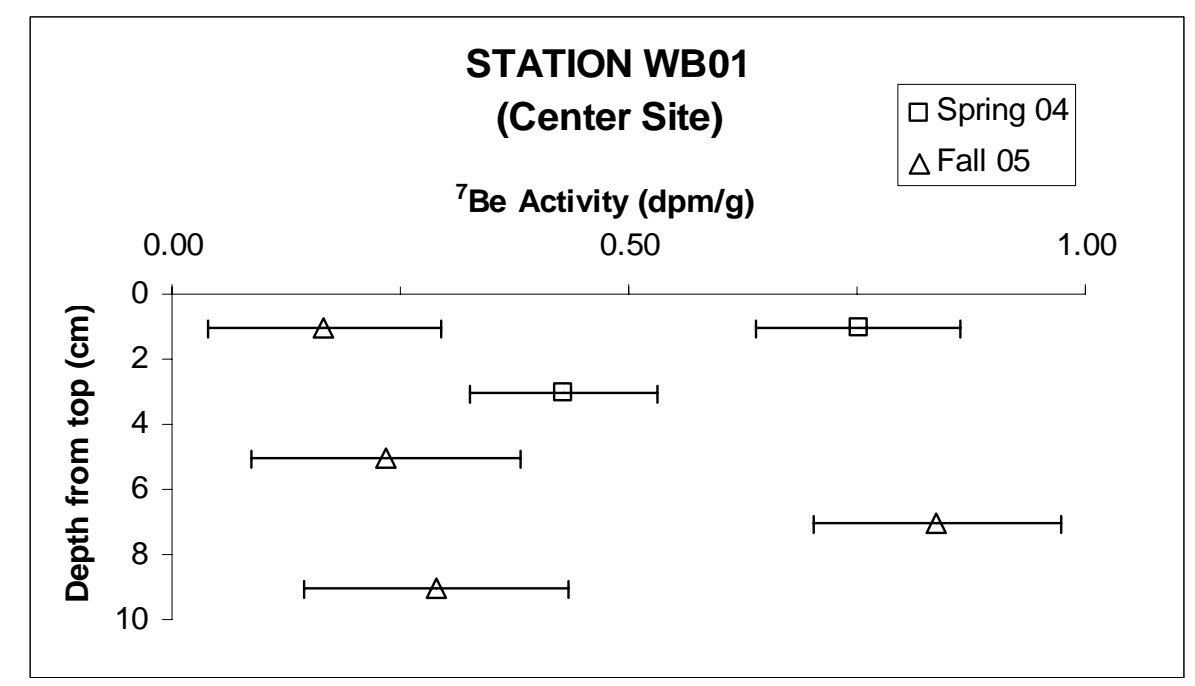

\section{WB01}

Spring 04

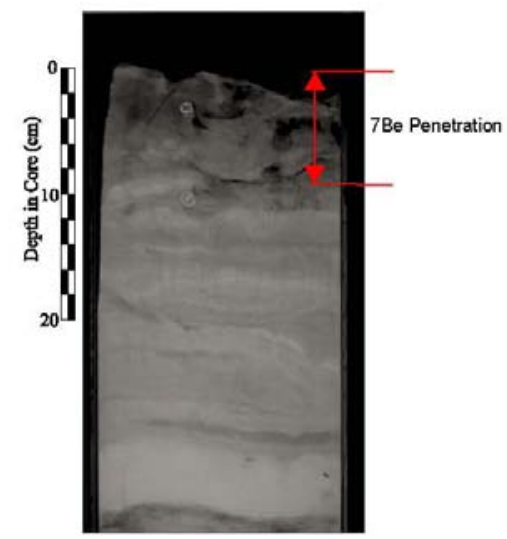

Fall 05

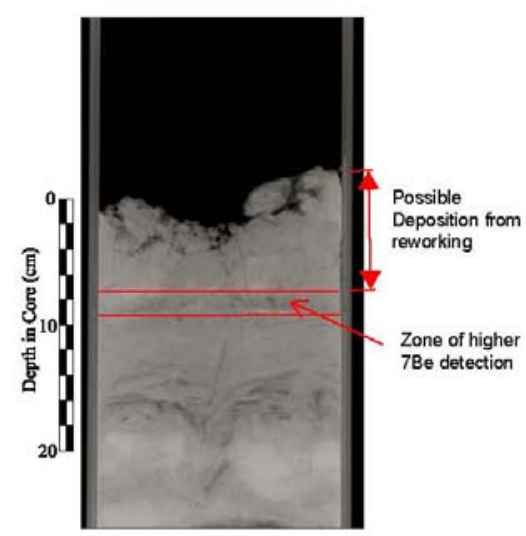

Fall 04
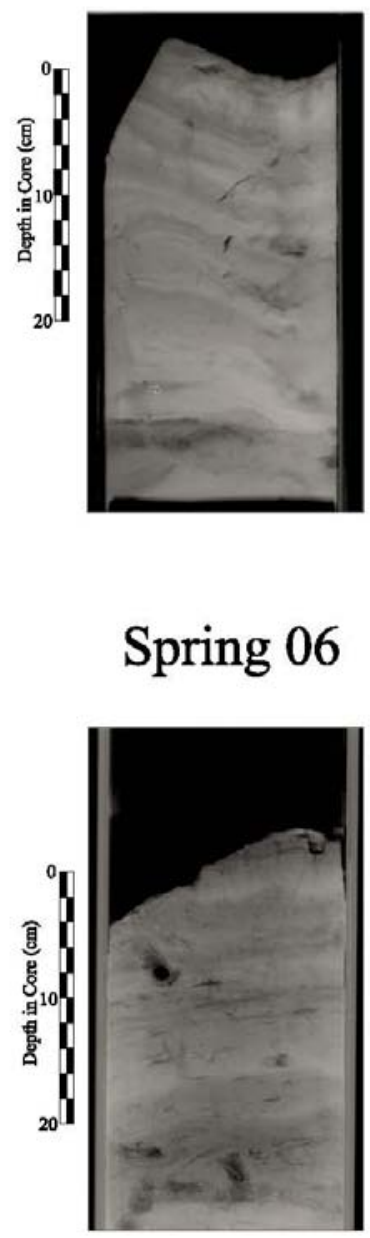

Note: The Spring 2004 image shows a dark bed of sediment at the top of the sample, indicative of newly deposited sediment with high water content It is less compacted than the sediments below and corresponds to $4 \mathrm{~cm}$ of ${ }^{7} \mathrm{Be}$ penetration. The Fall $2005{ }^{7} \mathrm{Be}$ data indicate a higher activity at around $8 \mathrm{~cm}$ deep which is associated with $a$ thin lamination of darker sediment in the $X$-radiograph with a thick homogeneous bed above. The Fall 2004 and Spring 2006 images indicate no recent depositional activity, consistent with the ${ }^{7} \mathrm{Be}$ results.

Figure 3-8. ${ }^{7}$ Be Activity Profiles and X-Radiographs for Site WB01 

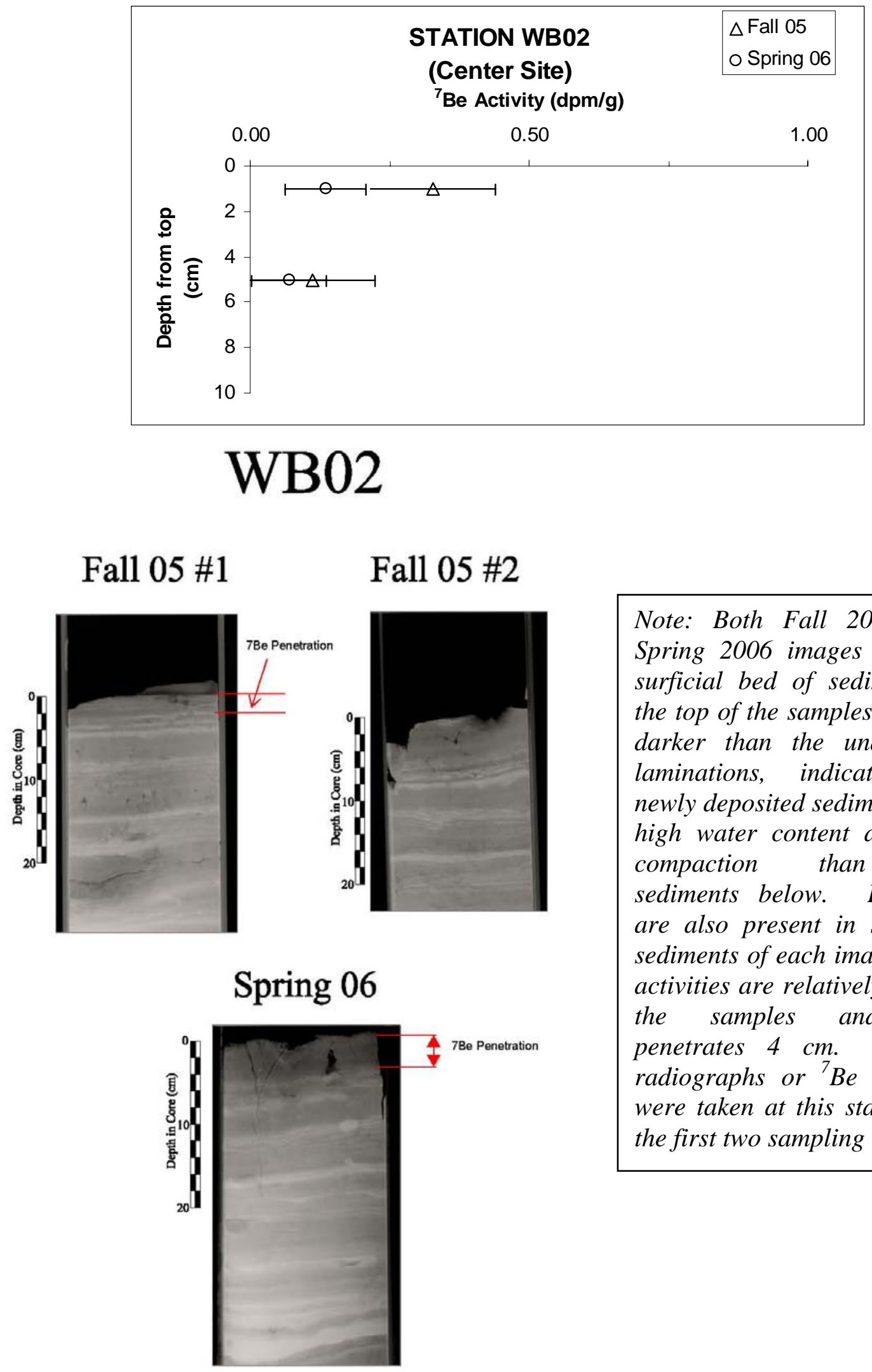

Note: Both Fall 2005 and Spring 2006 images show a surficial bed of sediment at the top of the samples slightly darker than the underlying laminations, indicative of newly deposited sediment with high water content and less compaction than the sediments below. Burrows are also present in surficial sediments of each image. ${ }^{7} \mathrm{Be}$ activities are relatively low in the samples and ${ }^{7} \mathrm{Be}$ penetrates $4 \mathrm{~cm}$. No $x$ radiographs or ${ }^{7} \mathrm{Be}$ samples were taken at this station for the first two sampling events.

Figure 3-9. ${ }^{7}$ Be Activity Profiles and X-Radiographs for Site WB02 


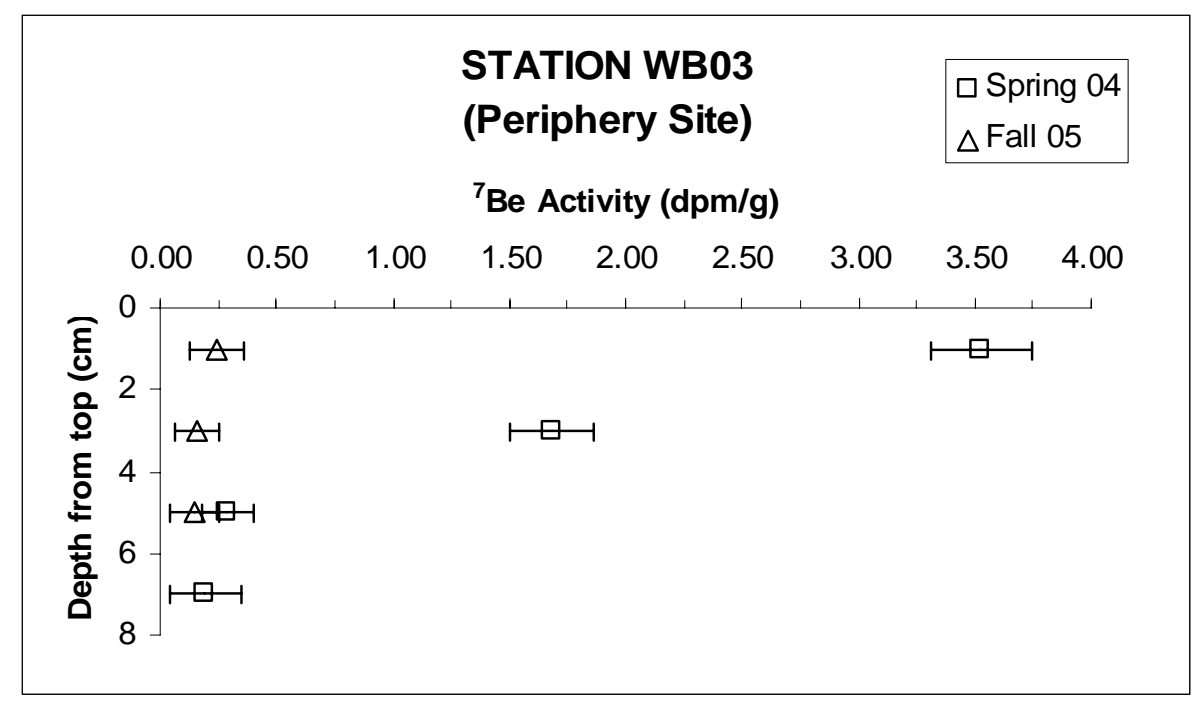

\section{WB03}

Spring 04

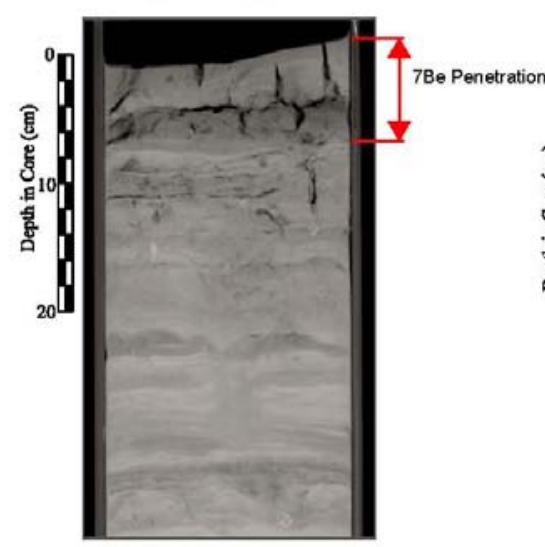

Fall 05

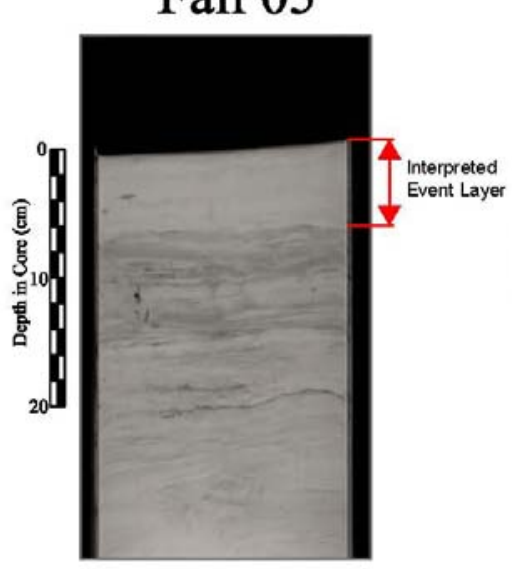

Fall 04

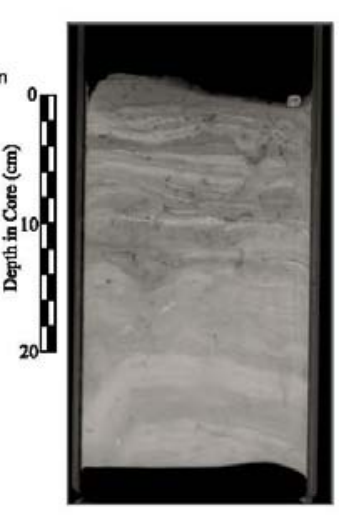

Spring 06

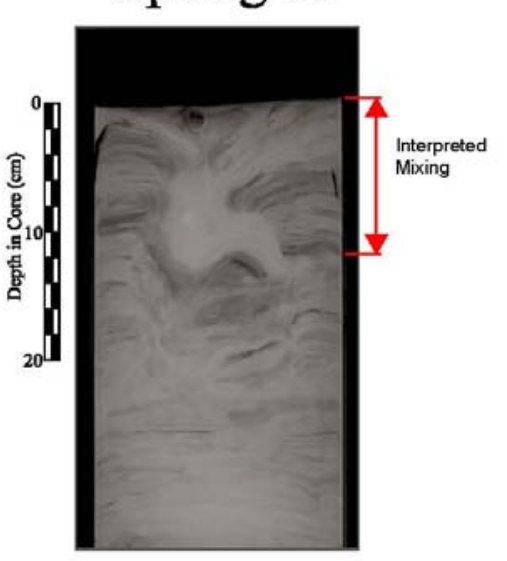

Note: The Spring 2004 image displays high water content evident in the dark pore spaces in the surface bed. This coincides with high ${ }^{7} \mathrm{Be}$ activity and $8 \mathrm{~cm}$ of penetration. The Fall 2004 image shows a series of thin laminations gradually lightening with depth and no detectable ${ }^{7} \mathrm{Be}$ activity. The Fall 2005 image shows a light surficial bed approximately $6 \mathrm{~cm}$ thick indicate of coarse sediments and/or low water content. Low ${ }^{7}$ Be activities were detected throughout this surficial bed. No ${ }^{7} \mathrm{Be}$ was detected in Spring 2006, although physical or biological mixing is evident in the image.

Figure 3-10. ${ }^{7}$ Be Activity Profiles and X-Radiographs for Site WB03 


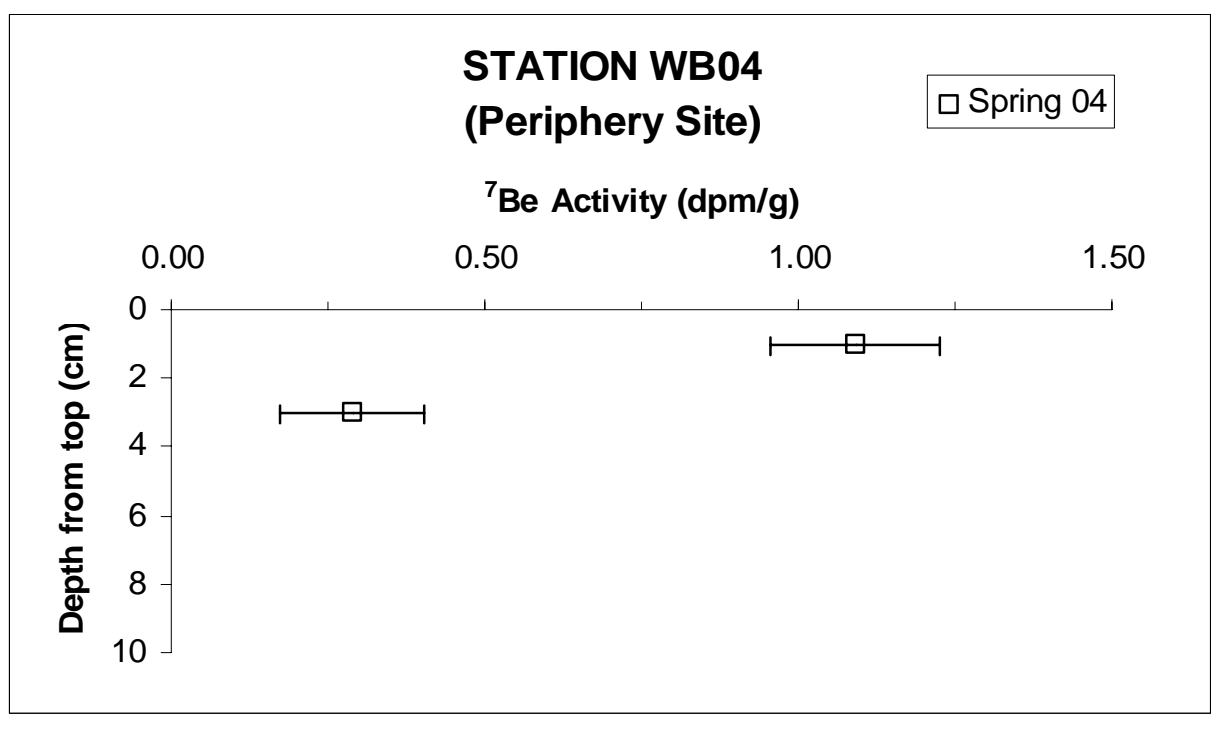

\section{WB04}

\section{Fall 05}
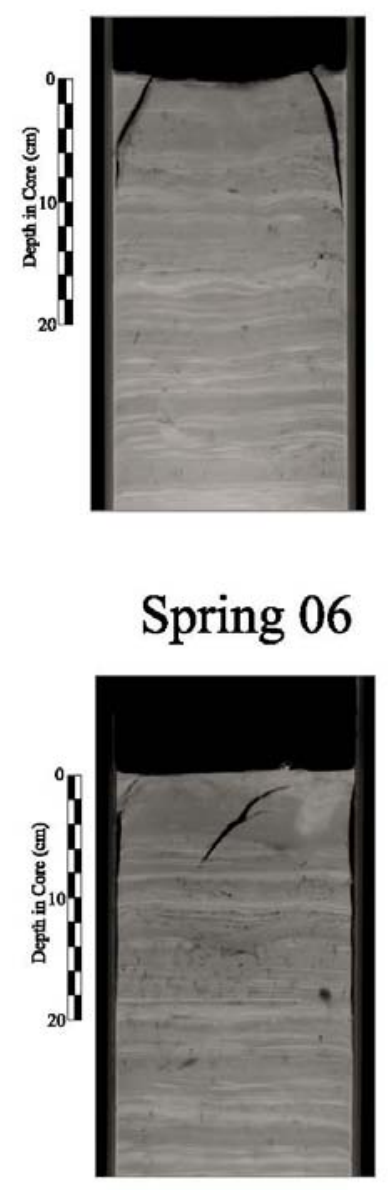

Note: The Fall 2005 image shows a dark surficial bed above $a$ multitude of laminations. The Spring 2006 image also displays this pattern but with some lighter sediments above the darker bed. No ${ }^{7}$ Be was detected for either of these events. ${ }^{7} \mathrm{Be}$ was detected down to $4 \mathrm{~cm}$ in Spring 2004. No $x$ radiographs were taken at this site for either of the first two sampling events.

Figure 3-11. ${ }^{7}$ Be Activity Profiles and X-Radiographs for Site WB04 


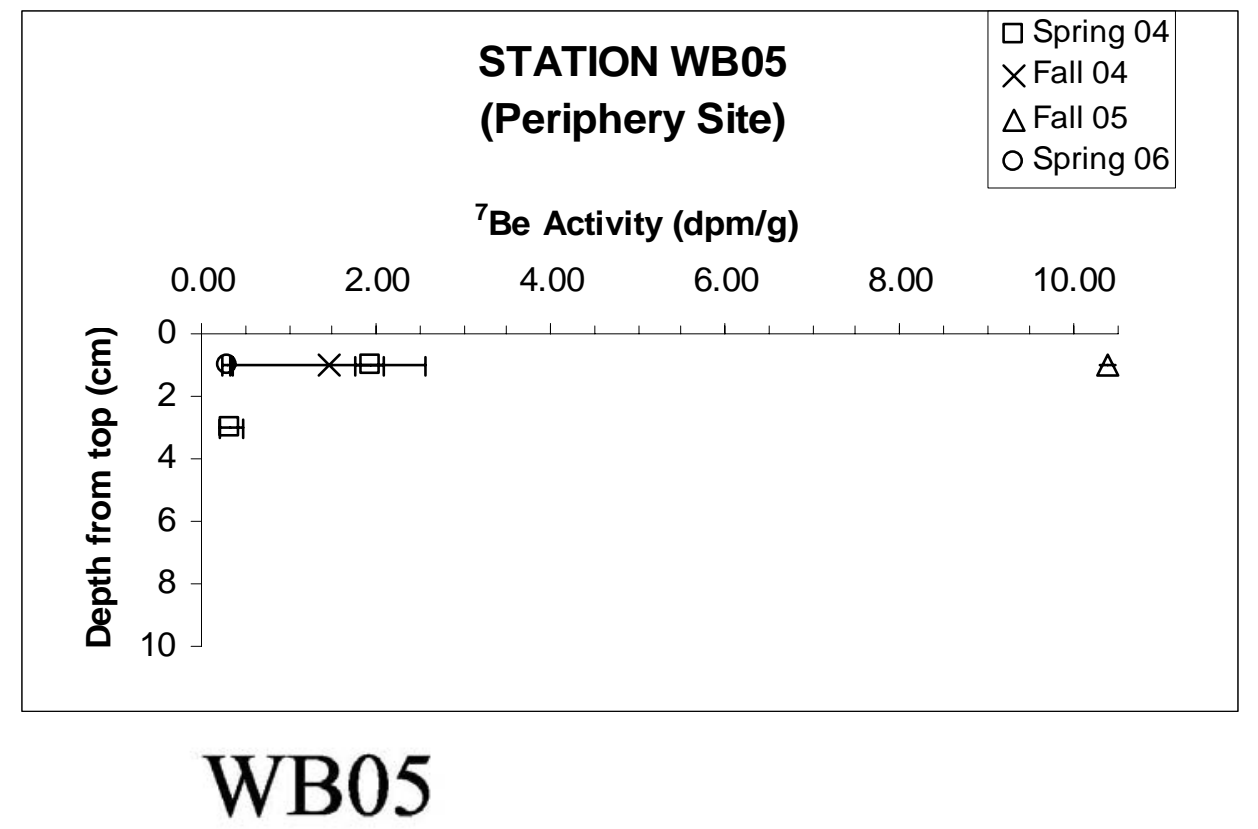

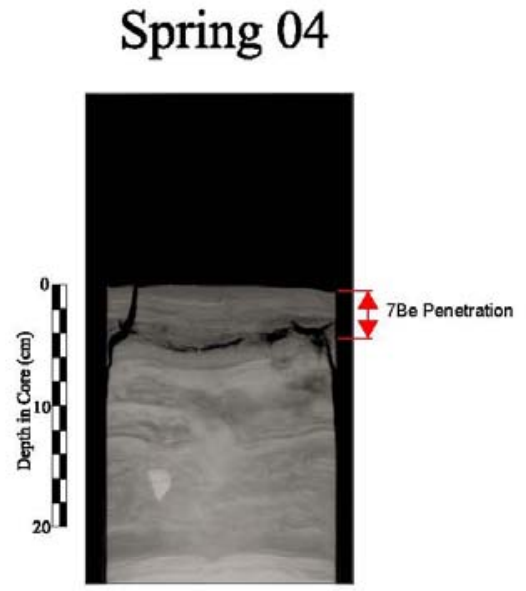

Fall 05

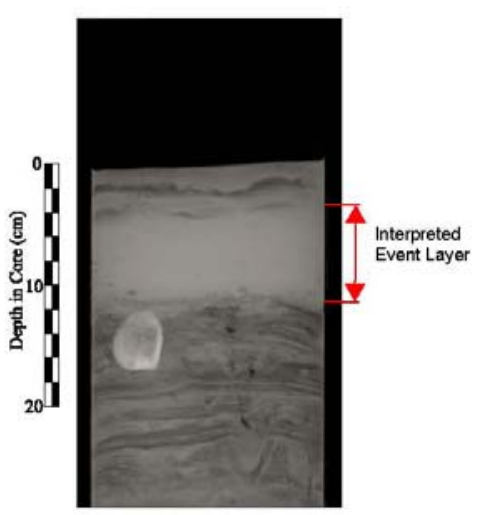

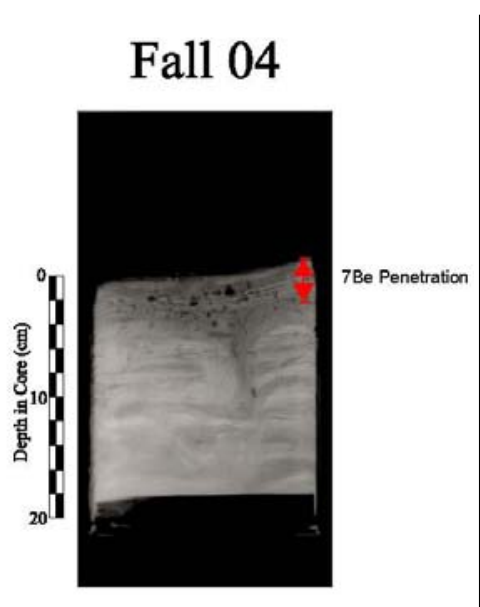

Spring 06

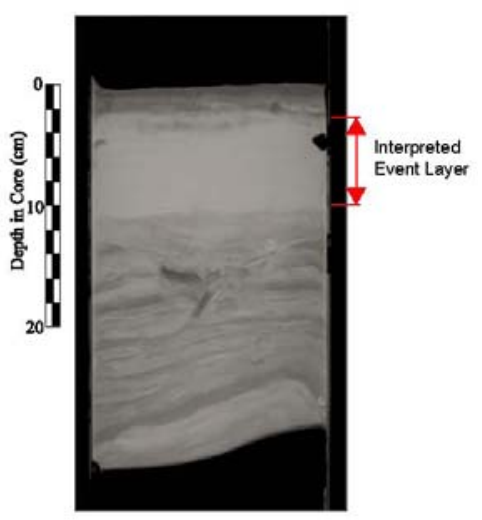

Note: The Spring and Fall 2004 images show thin, dark/transparent surface laminations corresponding to $4 \mathrm{~cm}$ and $2 \mathrm{~cm}$ of ${ }^{7} \mathrm{Be}$ penetrations, respectively. The Fall 2005 image shows a much thicker bed of relatively dense / coarse (bright) sediment above thin laminations of lower density sediment identified in previous sampling events. This layer also contains the highest ${ }^{7} \mathrm{Be}$ activity detected during any sampling event. Thin laminations of finer sediment become more evident above this layer in the Spring 2006 image, when the ${ }^{7}$ Be activity is lower.

Figure 3-12. ${ }^{7}$ Be Activity Profiles and X-Radiographs for Site WB05 


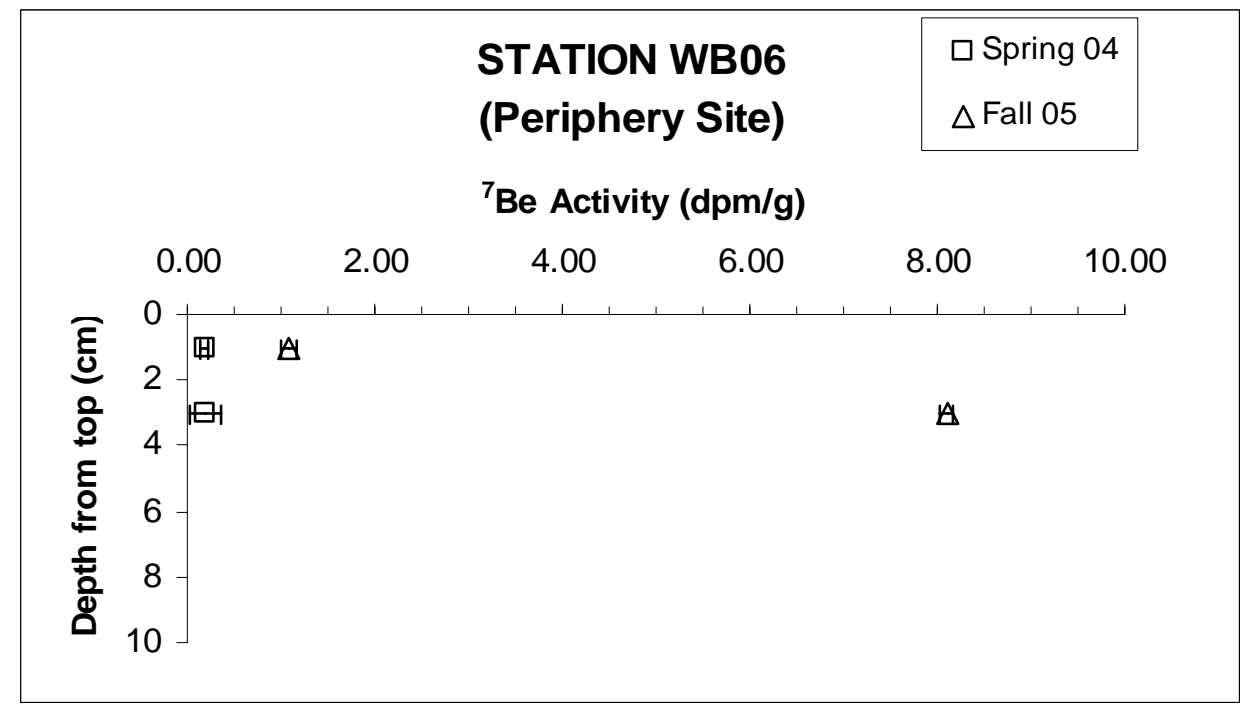
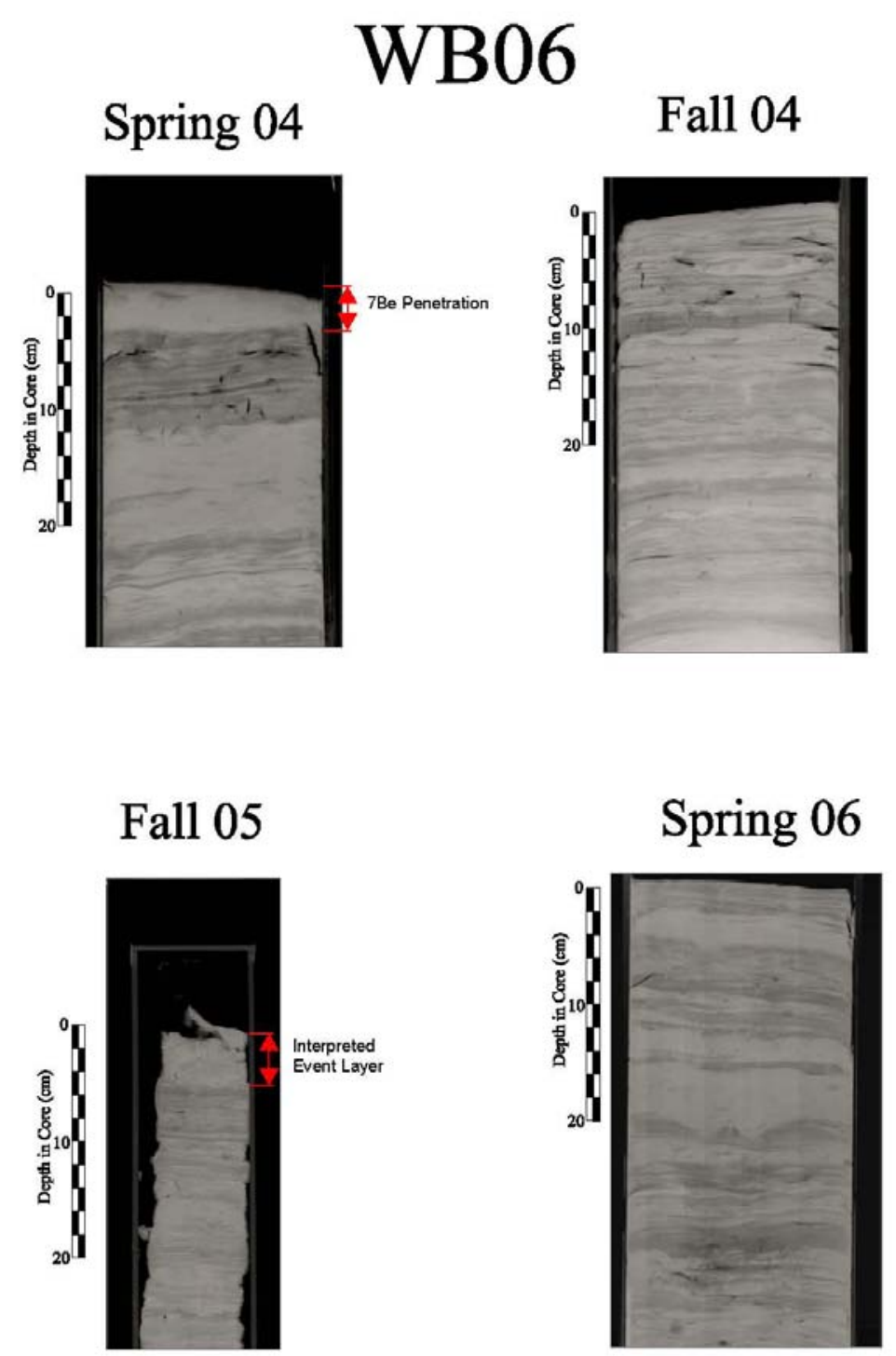

Note: The Spring 2004 image shows a bright surficial bed corresponding to $4 \mathrm{~cm}$ of ${ }^{7} \mathrm{Be}$ penetration and overlying thinner, darker laminations. This surficial layer is no longer evident in the Fall 2004 image, while the highly compacted thin laminations are still present. A surficial event layer is again present in the Fall 2005 image corresponding to very high ${ }^{7} \mathrm{Be}$ activities. Thin laminations again cover a lighter bed in the Spring 2006 image when no ${ }^{7} \mathrm{Be}$ was detected.

Figure 3-13. ${ }^{7}$ Be Activity Profiles and X-Radiographs for Site WB06 


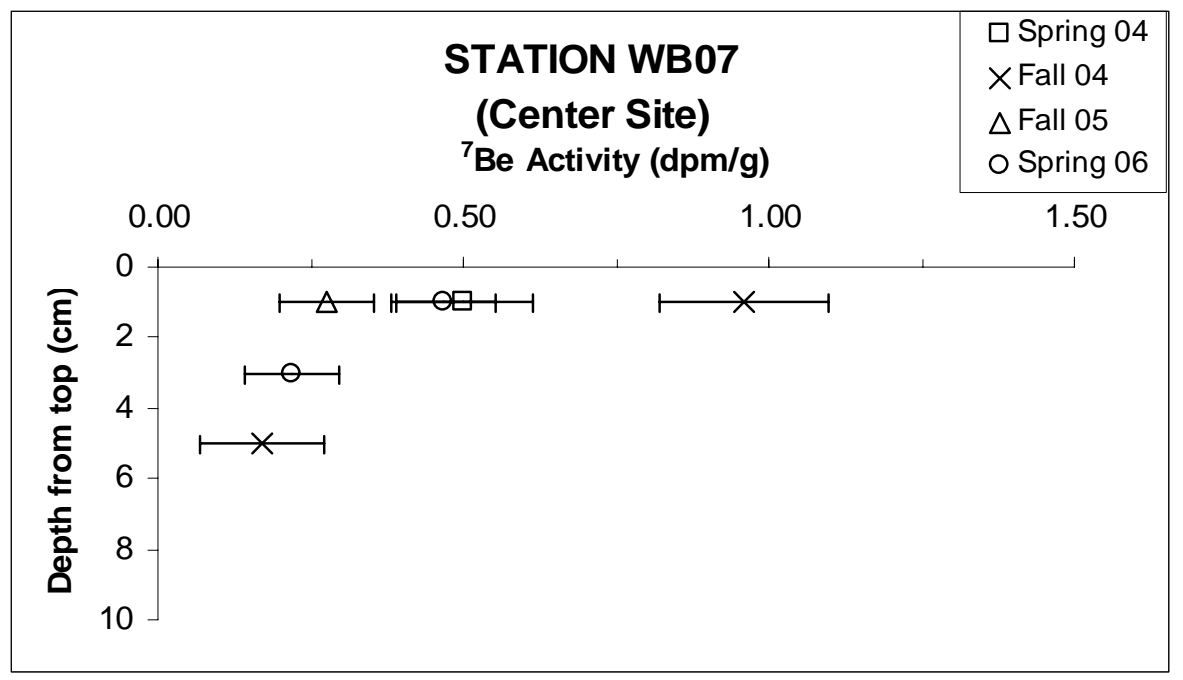

\section{WB07}
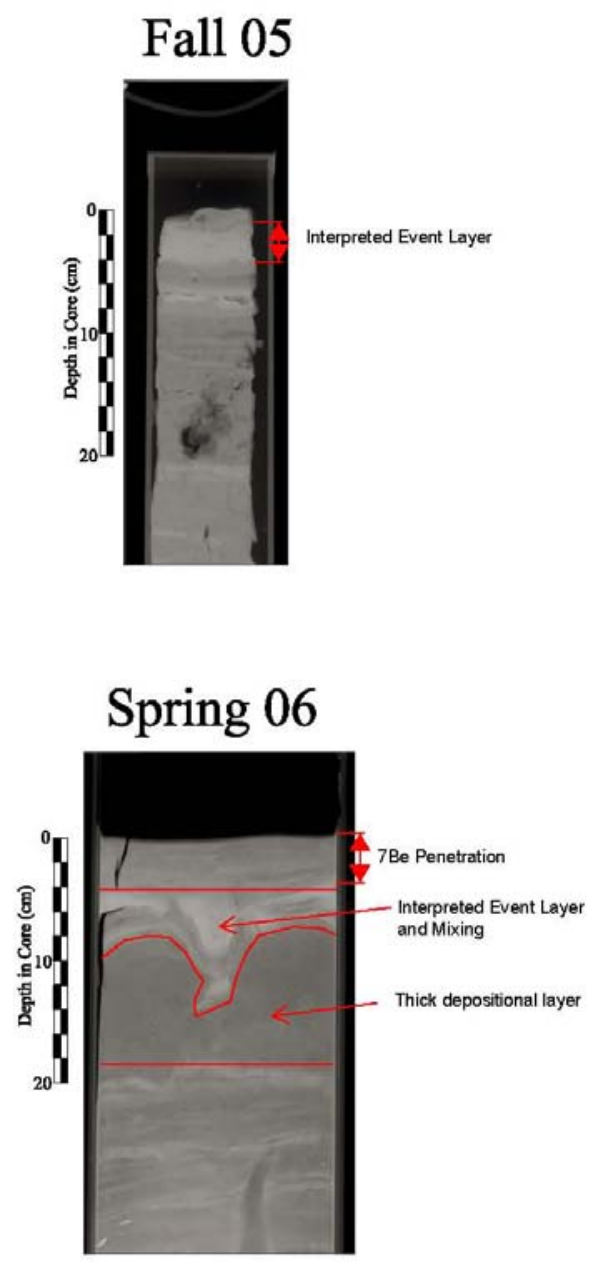

Note: Similar to stations WB05 and WB06, the Fall 2005 image for WB07 shows a surficial event layer but with lower amounts of detectable ${ }^{7} \mathrm{Be}$. The Spring $2006 X$-radiograph shows thin laminations corresponding to $4 \mathrm{~cm}$ of ${ }^{7} \mathrm{Be}$ penetration and overlying $a$ mixed bed, of potentially coarse sediments. Under this mixed bed lies an even thicker, darker bed. A SAR of $0.94 \mathrm{~cm} / \mathrm{mo}$ was estimated for Fall 2004 (Table 3-2). Underlying this thick layer are many thin laminations. No $x$-radiographs were taken at this station for the first two sampling events.

Figure 3-14. ${ }^{7}$ Be Activity Profiles and X-Radiographs for Site WB07 


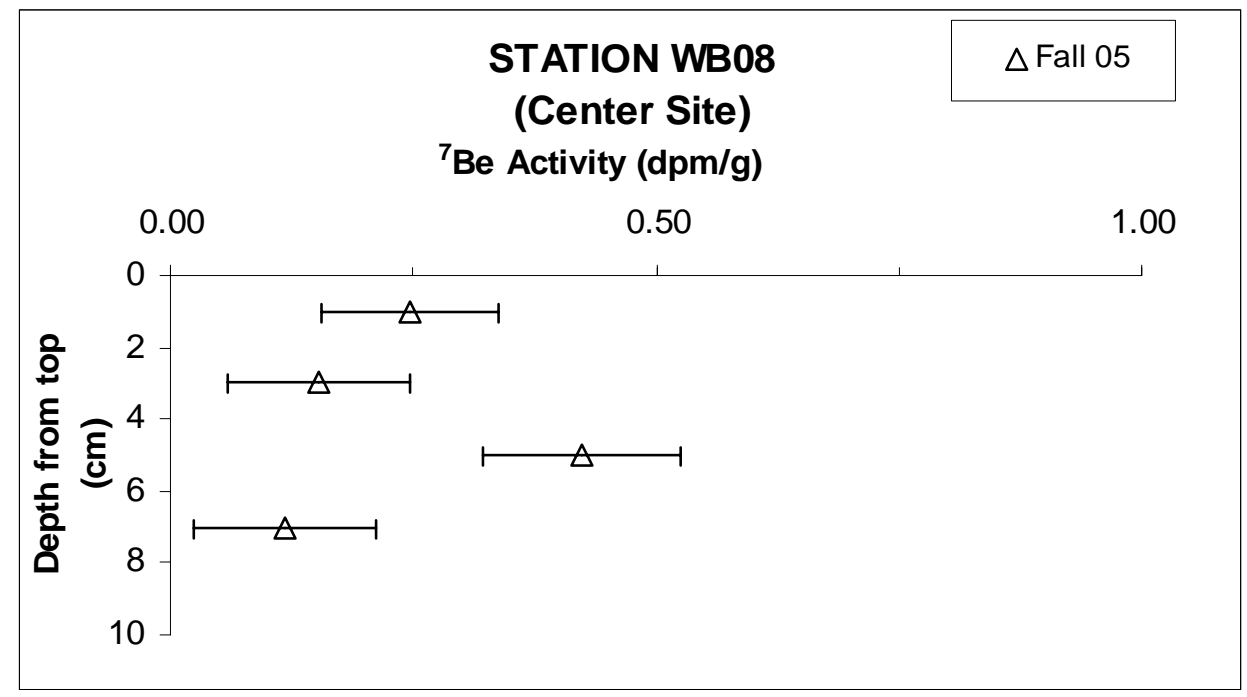

\section{WB08}

\section{Fall 05}
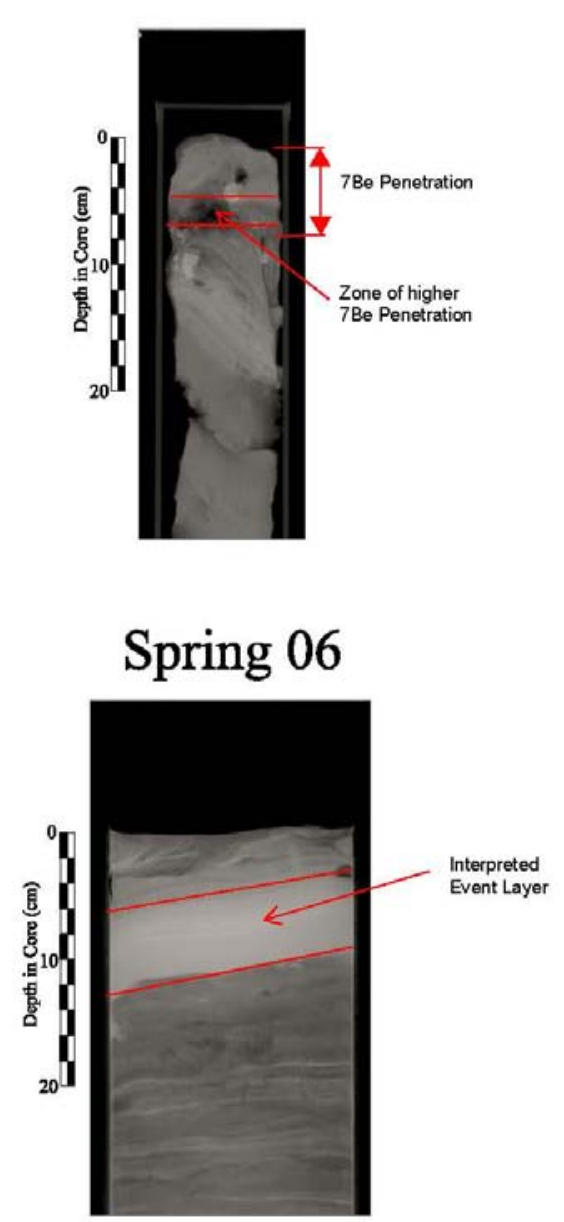

Note: Although disturbed during extraction in the field, the Fall 2005 image for shows a surficial event layer corresponding to detectable ${ }^{7} \mathrm{Be}$ down to $8 \mathrm{~cm}$ and $\mathrm{a}$ higher activity at $6 \mathrm{~cm}$. The Spring $2006 \quad X$-radiograph more distinctly shows this bedded layer of bright sediments. However, no ${ }^{7} \mathrm{Be}$ was detected for this sampling event. No $x$ radiographs or ${ }^{7} \mathrm{Be}$ samples were taken at this station for the first two samplina events.

Figure 3-15. ${ }^{7}$ Be Activity Profiles and X-Radiographs for Site WB08 


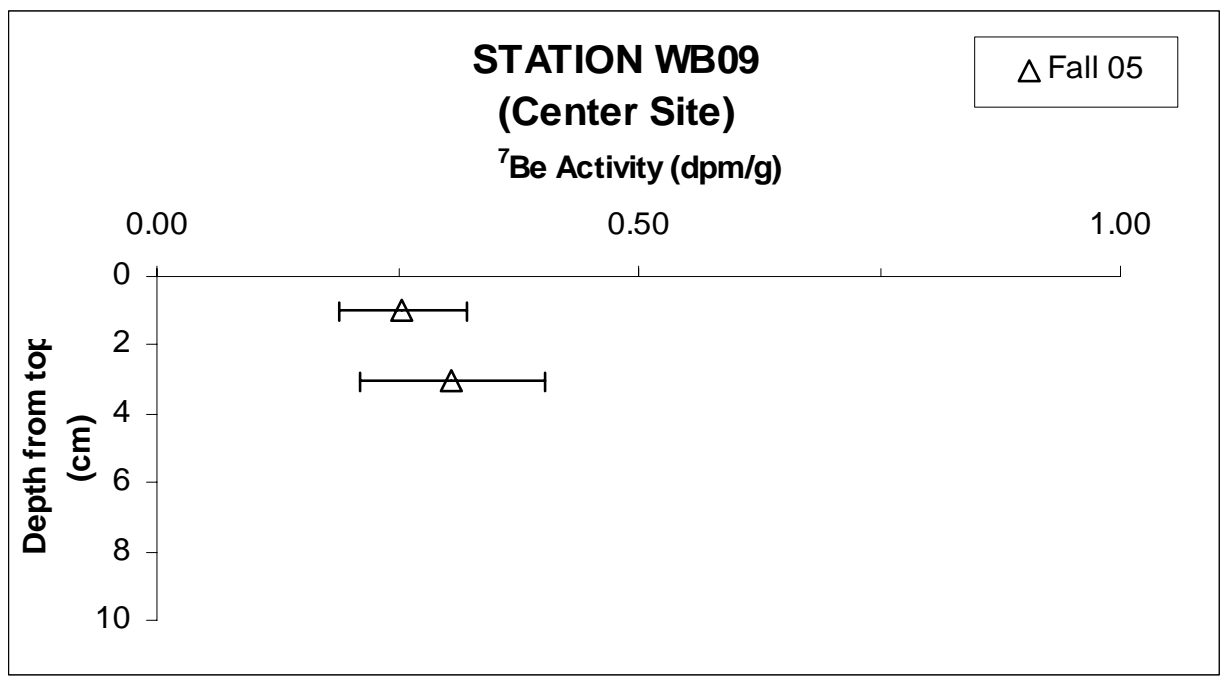

\section{WB09}
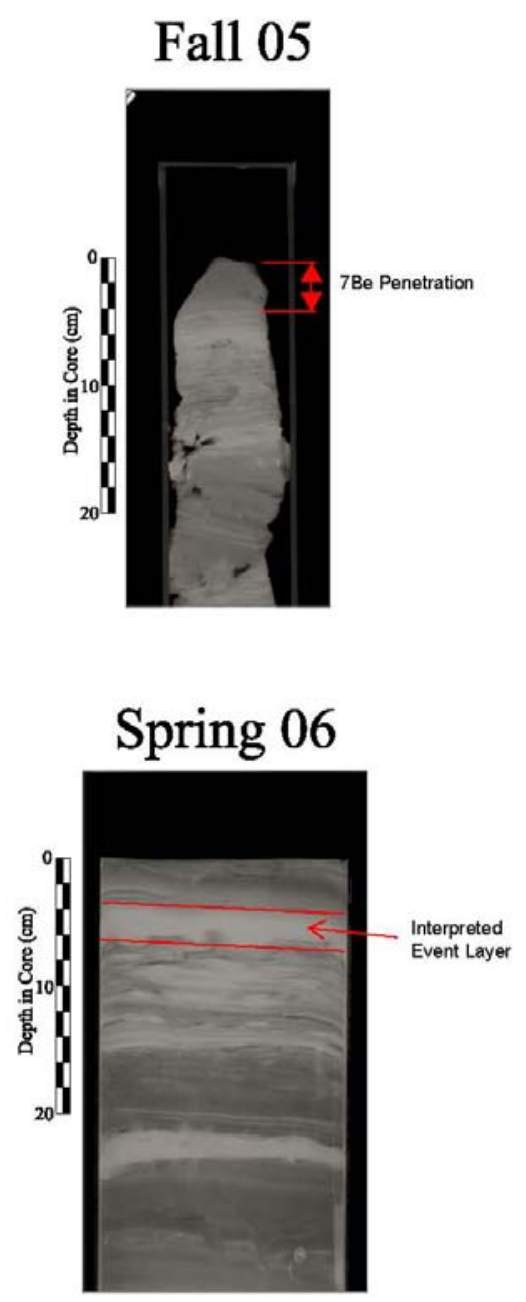

Note: WB09 shows very similar patterns with WB08, also located in the center of the bay. Although disturbed during extraction in the field, the Fall 2005 image for shows a surficial event layer corresponding to detectable ${ }^{7} \mathrm{Be}$ down to $4 \mathrm{~cm}$ and $\mathrm{a}$ higher activity at $4 \mathrm{~cm}$. The Spring 2006 X-radiograph more distinctly shows this bedded layer of bright sediments. However, no ${ }^{7} \mathrm{Be}$ was detected for this sampling event. No $x$ radiographs or ${ }^{7} \mathrm{Be}$ samples were taken at this station for the first two sampling events.

Figure 3-16. ${ }^{7}$ Be Activity Profiles and X-Radiographs for Site WB09 


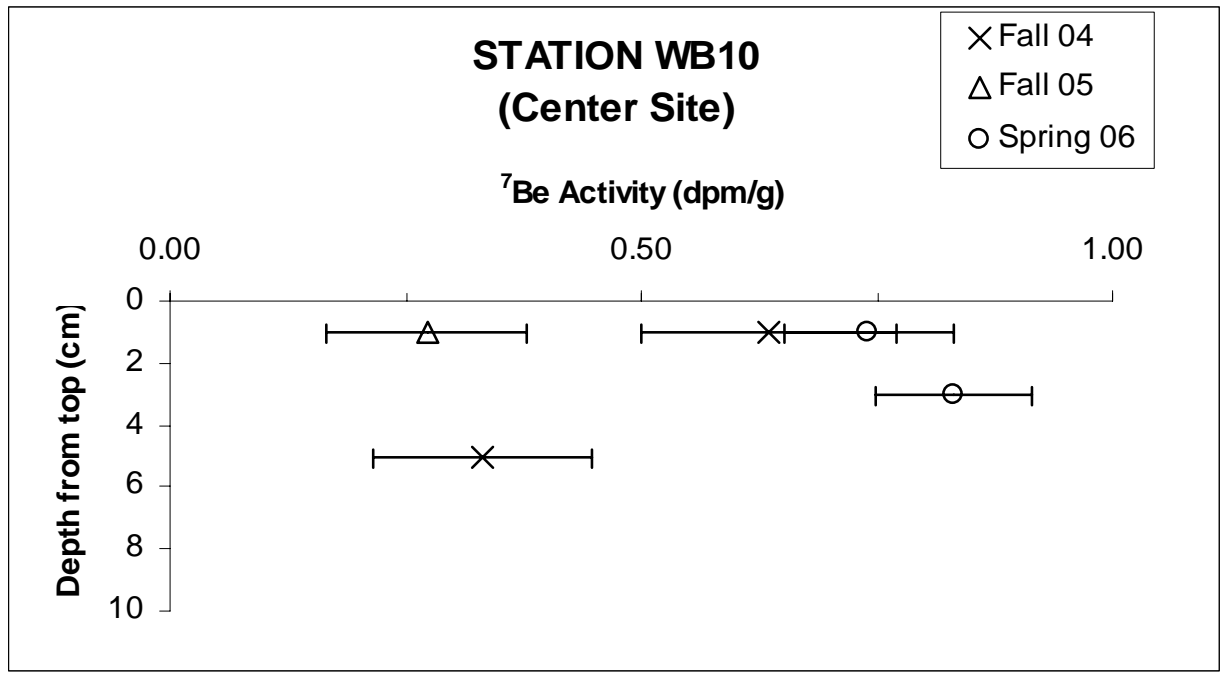

\section{WB10}

\section{Fall 05}
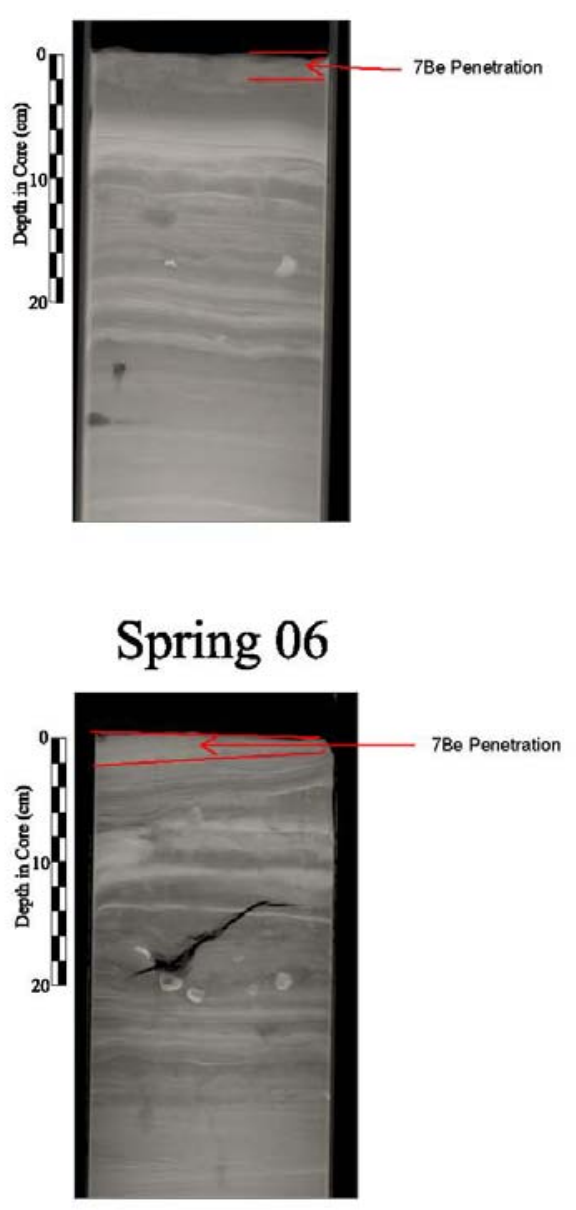

Note: The Fall 2005 image for shows multiple surficial beds overlying compacted thin laminations. The top bed is the most transparent and corresponds to $2 \mathrm{~cm}$ of ${ }^{7}$ Be penetration. The Spring 2006 image shows a single surficial bed corresponding to $4 \mathrm{~cm}$ of ${ }^{7} \mathrm{Be}$ penetration. 6 $\mathrm{cm}$ of ${ }^{7} \mathrm{Be}$ penetration was detected in Fall 2004. No xradiographs were taken at this station for the first two sampling events.

Figure 3-17. ${ }^{7}$ Be Activity Profiles and X-Radiographs for Site WB10 


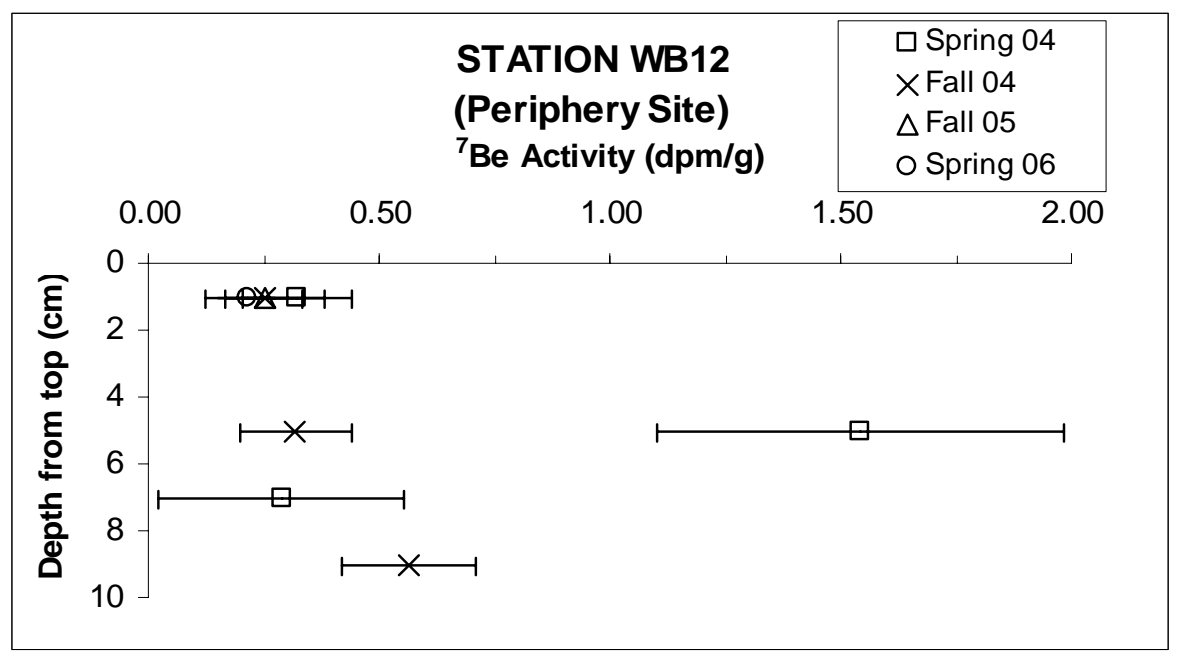

\section{WB12}
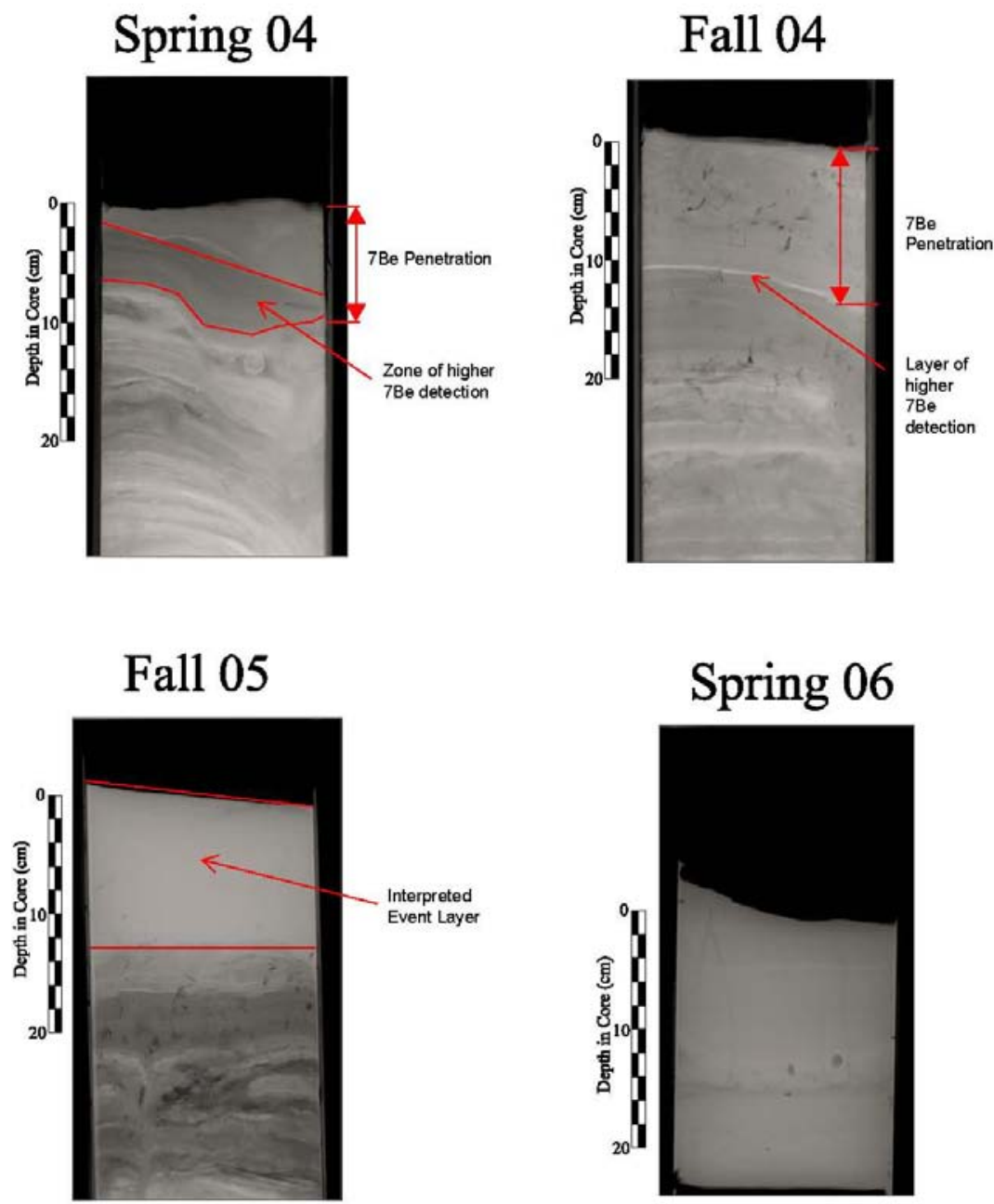

Note: The Spring 2004 image shows a thick surficial bed distinctly darker than the underlying sediments. This bed also corresponds to $8 \mathrm{~cm}$ of ${ }^{7} \mathrm{Be}$ penetration with a peak activity at $6 \mathrm{~cm}$. The Fall 2004 image also shows a thick surficial bed above a thin bright lamination which corresponds to a peak in ${ }^{7} \mathrm{Be}$ activity at $10 \mathrm{~cm}$. A surficial event layer is again present in the Fall 2005 and Spring 2006 images interpreted as bright, coarse sediment although little ${ }^{7} \mathrm{Be}$ activity was detected for either samplina event.

Figure 3-18. ${ }^{7}$ Be Activity Profiles and X-Radiographs for Site WB12 


\section{WB13}

\section{Spring 04}

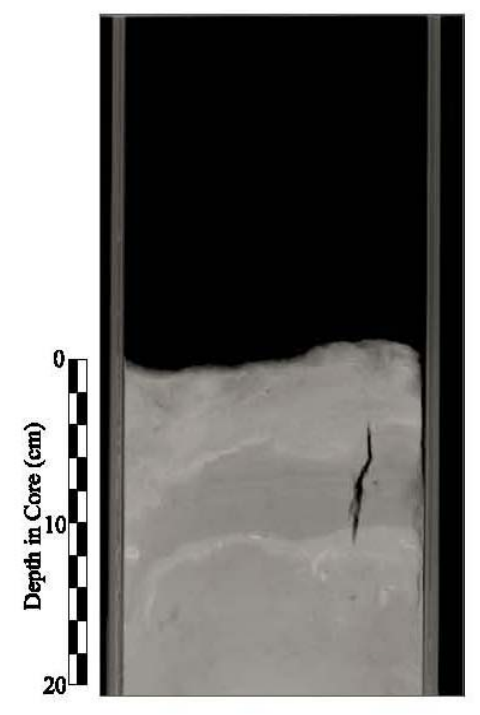

Note: The Spring and Fall 2004 images show a $20 \mathrm{~cm}$ thick, relatively homogeneous surficial bed. The Fall 2004 core penetrated deeper and the image shows multiple beds of darker sediments below the brigher surficial bed. ${ }^{7}$ Be was not detected for either event. No $x$ radiographs or ${ }^{7} \mathrm{Be}$ samples were taken at this station for the last two sampling events.

Figure 3-19. X-Radiographs for Site WB13 

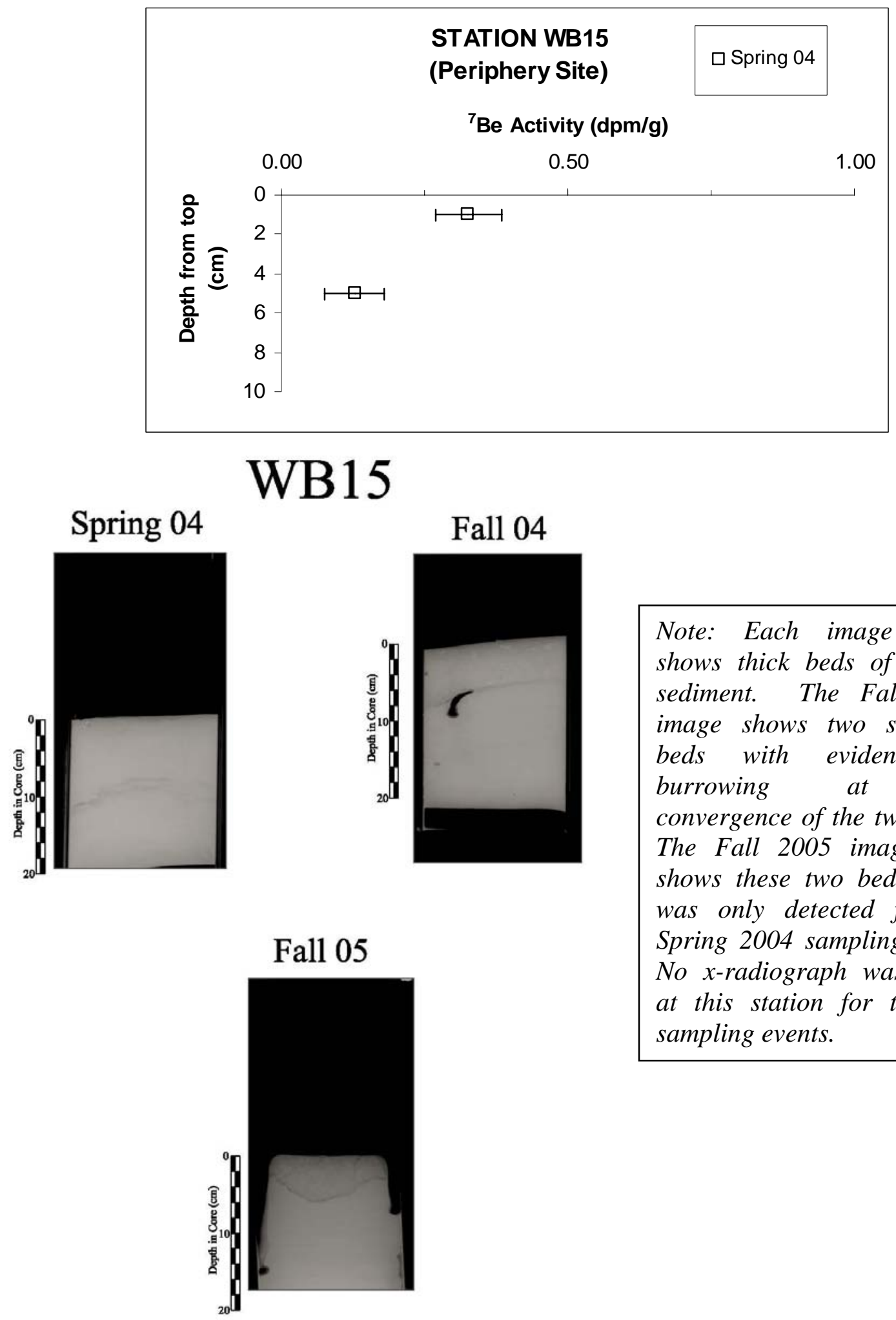

Note: Each image taken shows thick beds of coarse sediment. The Fall 2004 image shows two separate beds with evidence of burrowing at the convergence of the two beds. The Fall 2005 image also shows these two beds. ${ }^{7} \mathrm{Be}$ was only detected for the Spring 2004 sampling event. No $x$-radiograph was taken at this station for the last sampling events.

Figure 3-20. ${ }^{7}$ Be Activity Profiles and X-Radiographs for Site WB15 

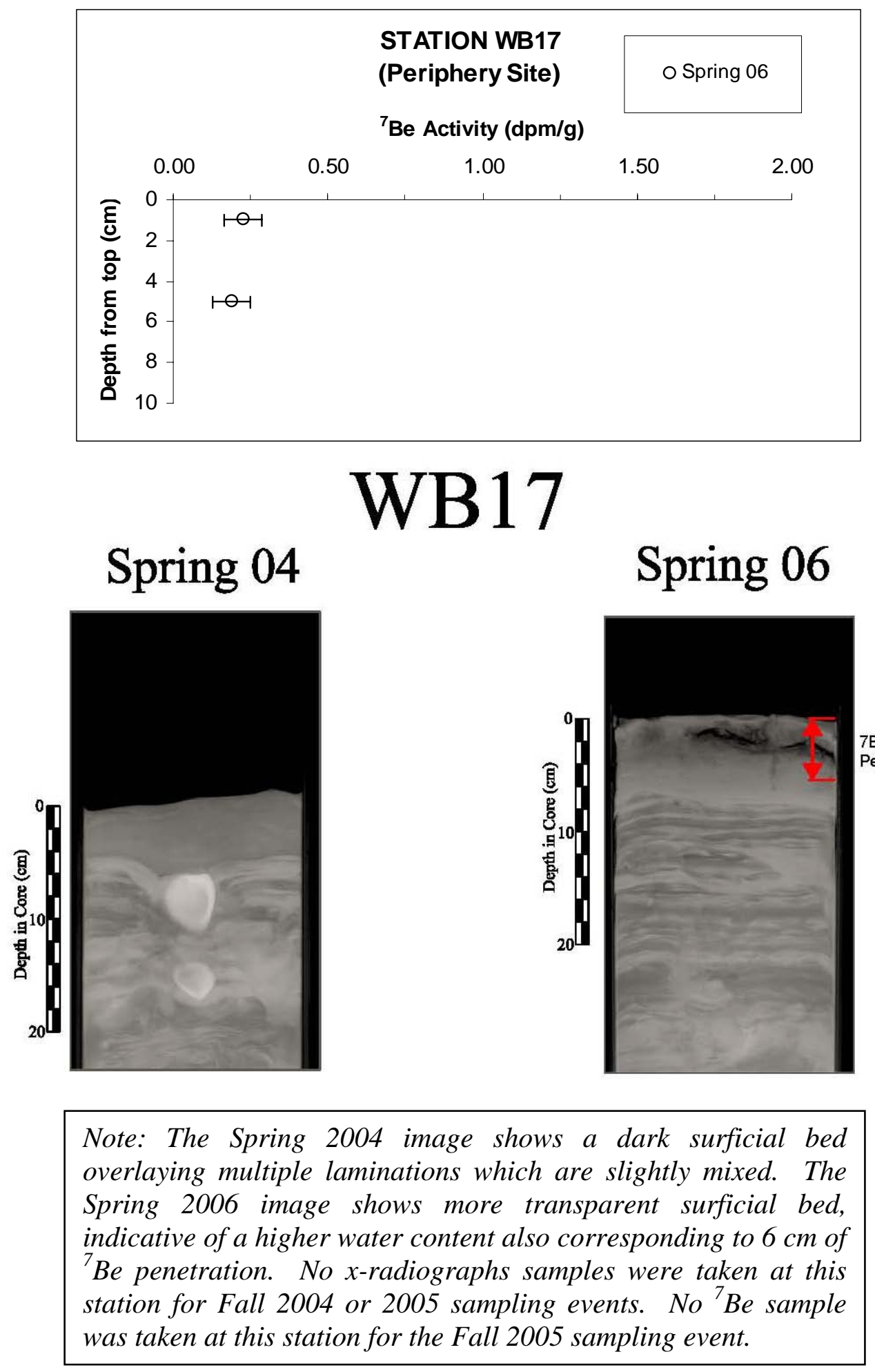

Figure 3-21. ${ }^{7}$ Be Activity Profiles and X-Radiographs for Site WB17 


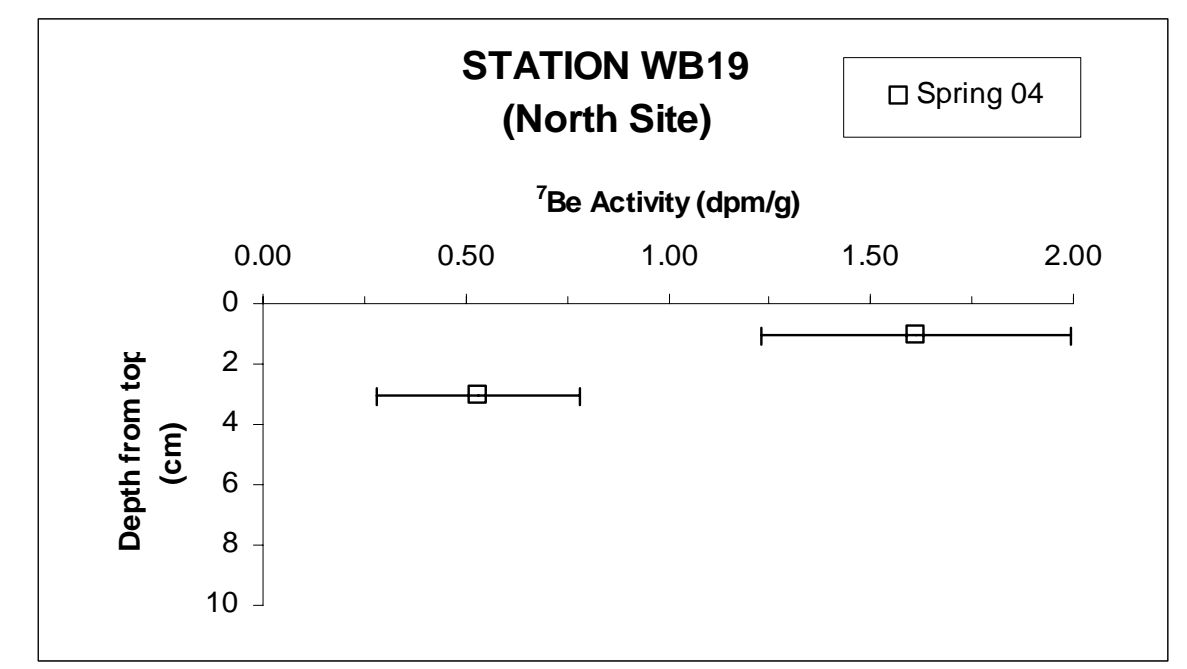

\section{WB19}

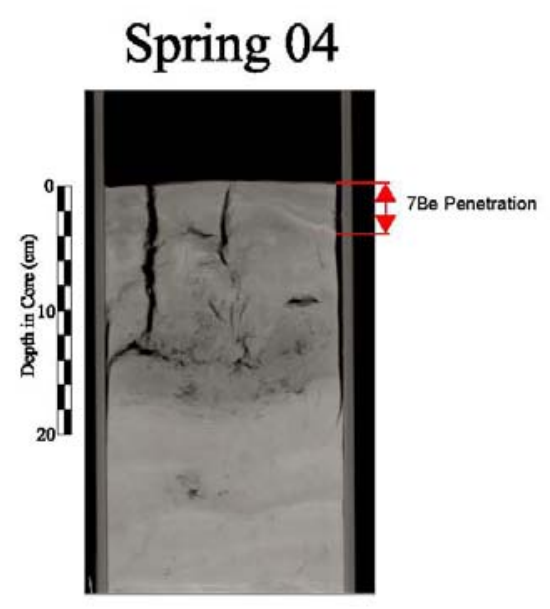

Fall 04

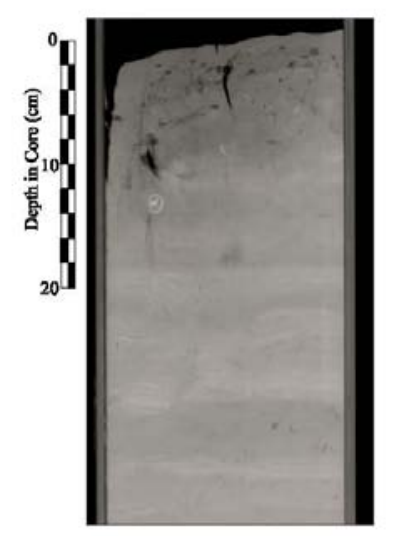

Figure 3-22. ${ }^{7}$ Be Activity Profiles and X-Radiographs for Site WB19
Note: The Spring $2004{ }^{7} \mathrm{Be}$ penetration is approximately $4 \mathrm{~cm}$ with surface laminations overlying a bed of organic material evident by darker color. Brighter (higher density, possibly coarser) laminations begin at approximately $18 \mathrm{~cm}$ below the sample surface. The darker less compact organicrich bed is also seen the Fall $2004 X$-radiograph with no ${ }^{7} \mathrm{Be}$ detected for this sampling event. No $x$ radiographs or ${ }^{7} \mathrm{Be}$ samples were taken at this station for the last two sampling events. 

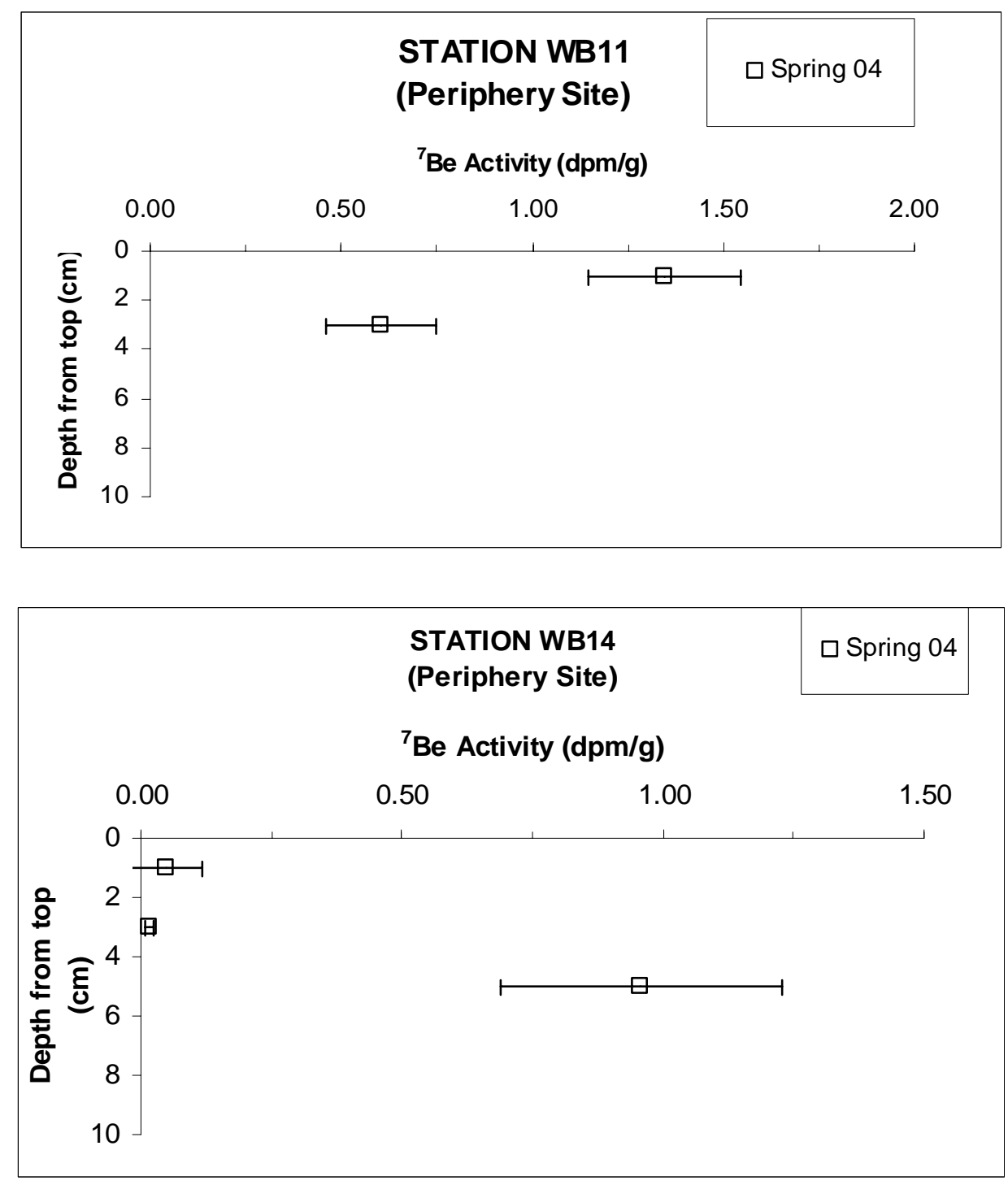

Note: ${ }^{7}$ Be samples were taken at station WB11 for the first two sampling events only. ${ }^{7}$ Be samples were taken at station WB14 for the first sampling event only. No x-radiographs samples were taken at either site for any sampling event.

Figure 3-23. ${ }^{7}$ Be Activity Profiles for Sites WB11, \& WB14 

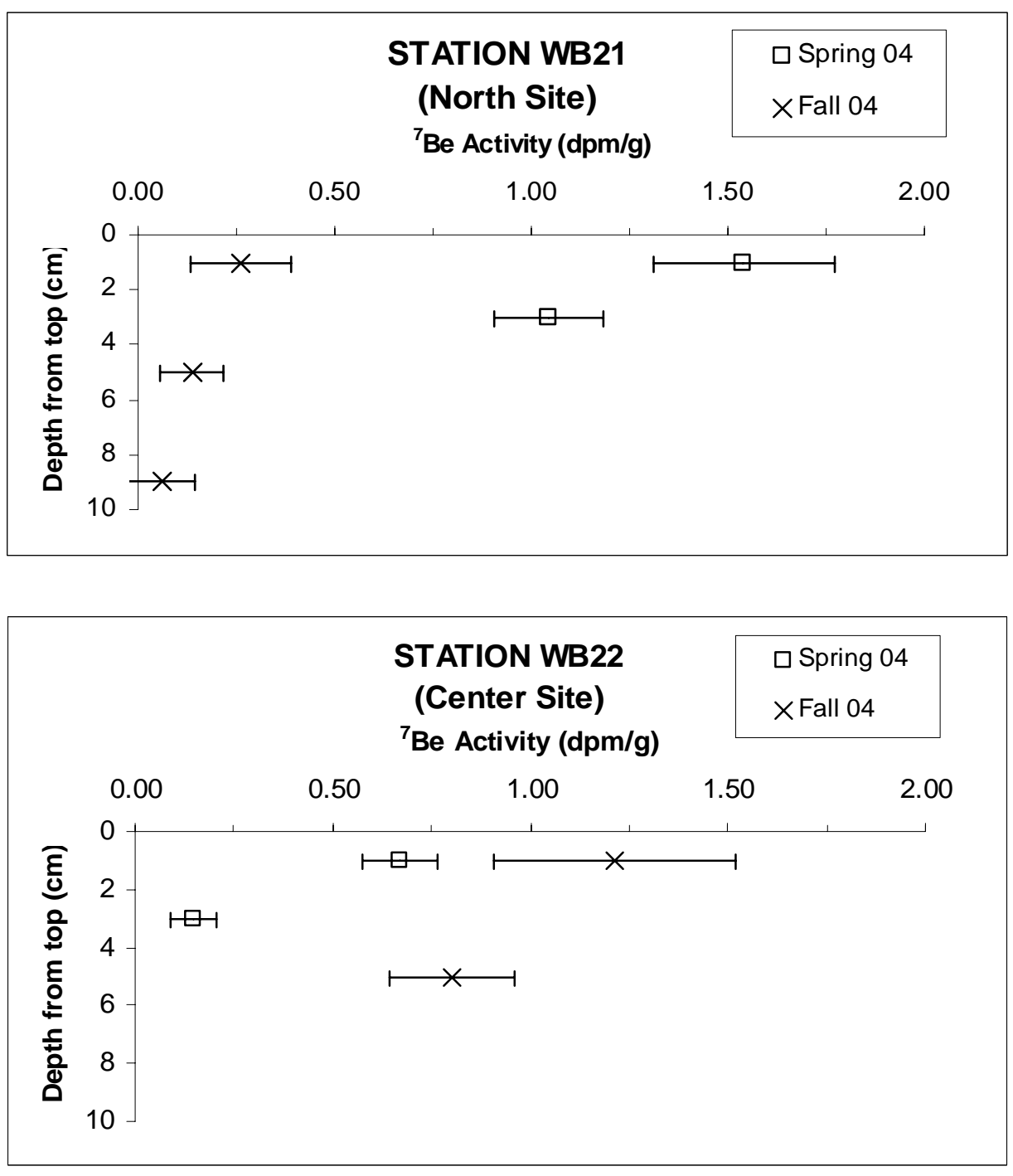

Note: ${ }^{7}$ Be samples were taken at station WB21 and WB22 for the first two sampling events only. No x-radiographs samples were taken at either site for any sampling event.

Figure 3-24. ${ }^{7}$ Be Activity Profiles for Sites WB21 \& WB22 
Table 3-2. Average Median Grain Sizes (microns) for Top $10 \mathrm{~cm}$.

\begin{tabular}{|c|c|c|c|c|c|}
\hline Site ID & Spring 04 & Fall 04 & Fall 05 & Spring 06 & Category \\
\hline WB01 & NS & NS & 4.36 & 2.31 & Center \\
\hline WB03 & 4.03 & NS & NS & 21.1 & Periphery \\
\hline WB04 & 9.12 & NS & 10.6 & 5.00 & Periphery \\
\hline WB05 & NS & 9.82 & 52.6 & 28.8 & Periphery \\
\hline WB06 & 13.4 & NS & NS & 16.6 & Periphery \\
\hline WB10 & NS & 15.9 & NS & 12.9 & Center \\
\hline WB17 & NS & 3.25 & NS & 21.0 & Periphery \\
\hline Average & 8.84 & 9.64 & 22.5 & 15.4 & \\
\hline
\end{tabular}

NS $=$ Not Sampled

Figure 3-25 shows the grain size plots for site WB05. The Fall 2004 WB05 sediment core decreases in median grain size from $14.5 \mu \mathrm{m}$ at $2 \mathrm{~cm}(0.8 \mathrm{in})$ to $5.79 \mu \mathrm{m}$ at $6 \mathrm{~cm}(2.4 \mathrm{in})$. In the Fall 2005, grain sizes increases from approximately $41.0 \mu \mathrm{m}$ at $2 \mathrm{~cm}$ (0.8 in) to above 62.5 $\mu \mathrm{m}$ (sand) at $4 \mathrm{~cm}$ (1.6 in) which is the upper detectible grain size limit of the Sedigraph. This layer of sandy material extended down to $8 \mathrm{~cm}$ (3.2 in), below which the grain size decreased to

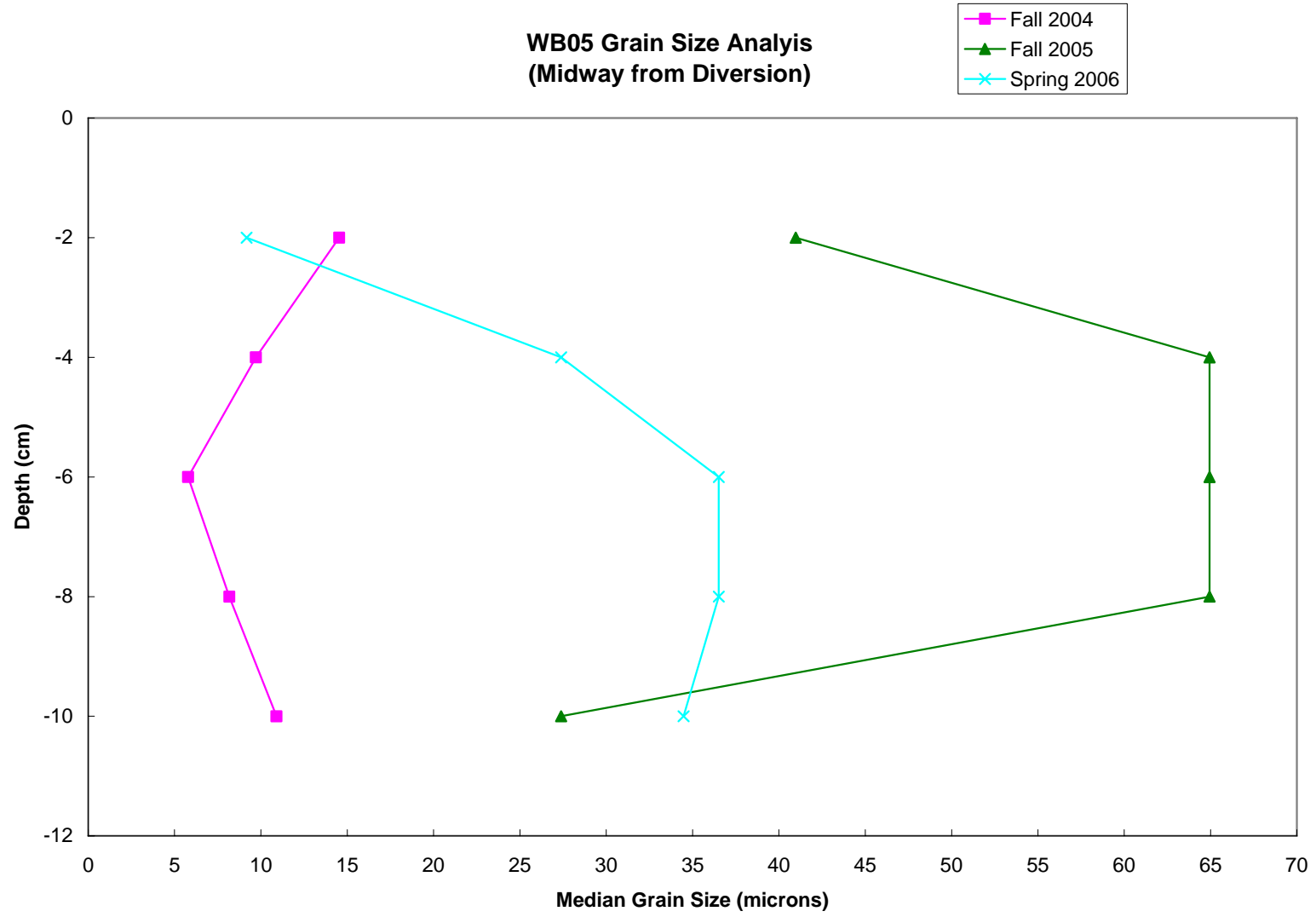

Figure 3-25. Median Grain Sizes for Site WB05 
$27.4 \mu \mathrm{m}$. In the Spring of 2006, grain sizes increase from $10 \mu \mathrm{m}$ at $2 \mathrm{~cm}(0.8 \mathrm{in})$ to $35 \mu \mathrm{m}$ at 6 to $10 \mathrm{~cm}$ (2.4 to $3.9 \mathrm{in})$. Additional grain size plots for the other sites analyzed are presented in Appendix D.

\subsection{Elevation Surveys}

Using methods described in Section 2.2, elevation surveys were conducted prior to diversion construction in 2003 and after construction in November 2005 and April 2006. Because of calibration issues and equipment malfunctions, the November 2005 data were deemed unreliable. Therefore, survey comparisons will be made between the 2003 preconstruction data and the 2006 post-construction data only.

All raw survey data were processed and plotted on cross-sections taken along survey lines common to the two surveys being compared. These lines are shown on Figure 2-2 and in Appendix B and all cross-sections are included in Appendix E. The southernmost commonly surveyed line from the diversion is line 1-2 and the northernmost and closest to the diversion is line 29-30. Appendix E also presents cross-sections for lines surveyed through the center of the bay and across the width of the diversion cut.

The raw data used to produce the cross-sections was also used to produce bathymetric contours of the bay bottom. Figures 3-26 and 3-27 show these contours in the NAVD 88 elevation datum for 2003 and 2006, respectively. In comparing the two figures, it is evident that a sub-aqueous channel has developed through the center of the bay following the preconstruction survey, delineated by the $-3.0^{\prime}$ contour. The $-4.0^{\prime}$ and $-5.0^{\prime}$ elevation contour positions remained virtually unchanged between 2003 and 2006, however -6.0' elevations have encroached into the bay. Deeper contours have also moved closer to the shoreline edges in most parts of the bay. 


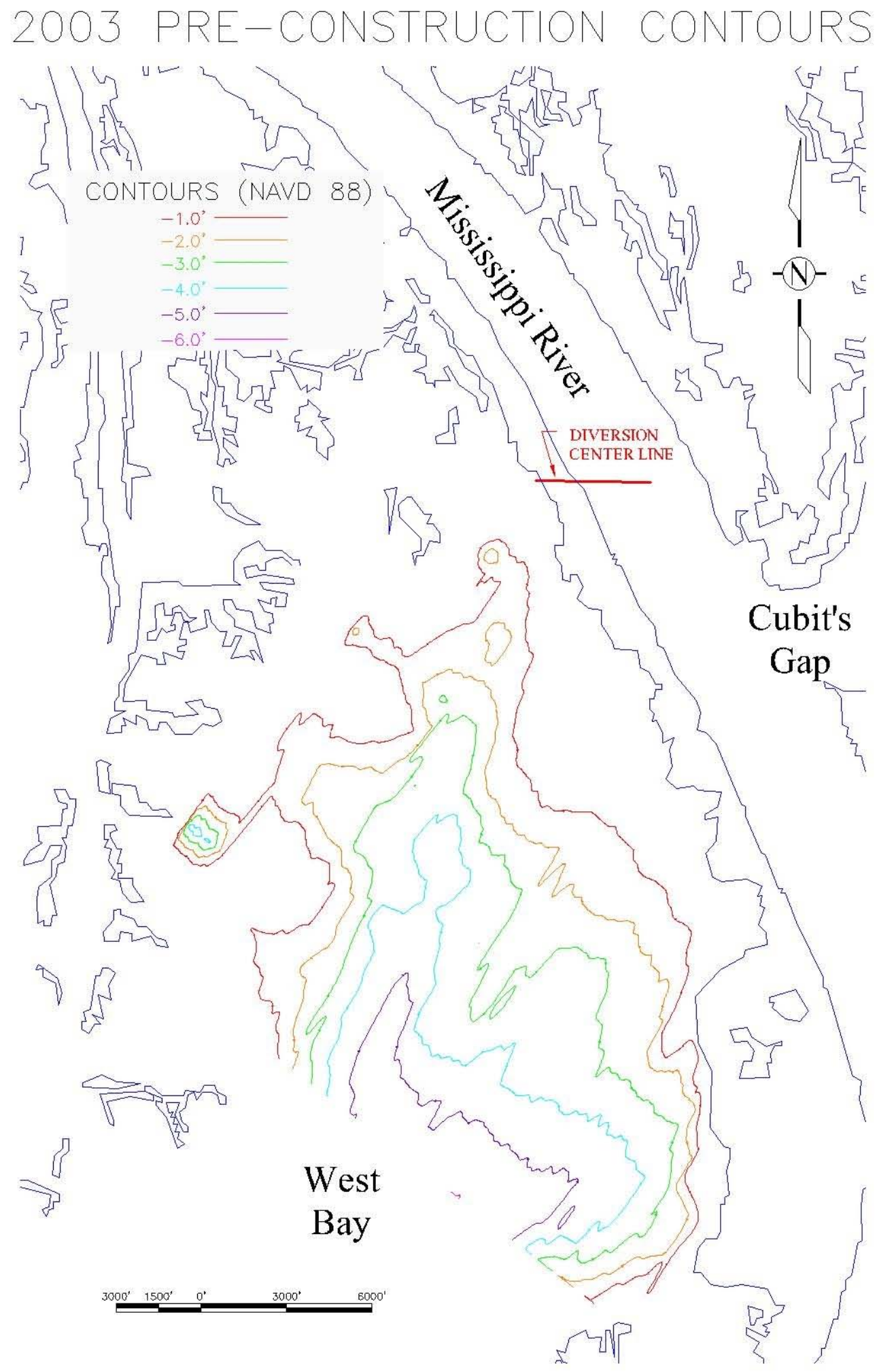

Figure 3-26. Pre-construction Bathymetric Contours Measured in 2003 


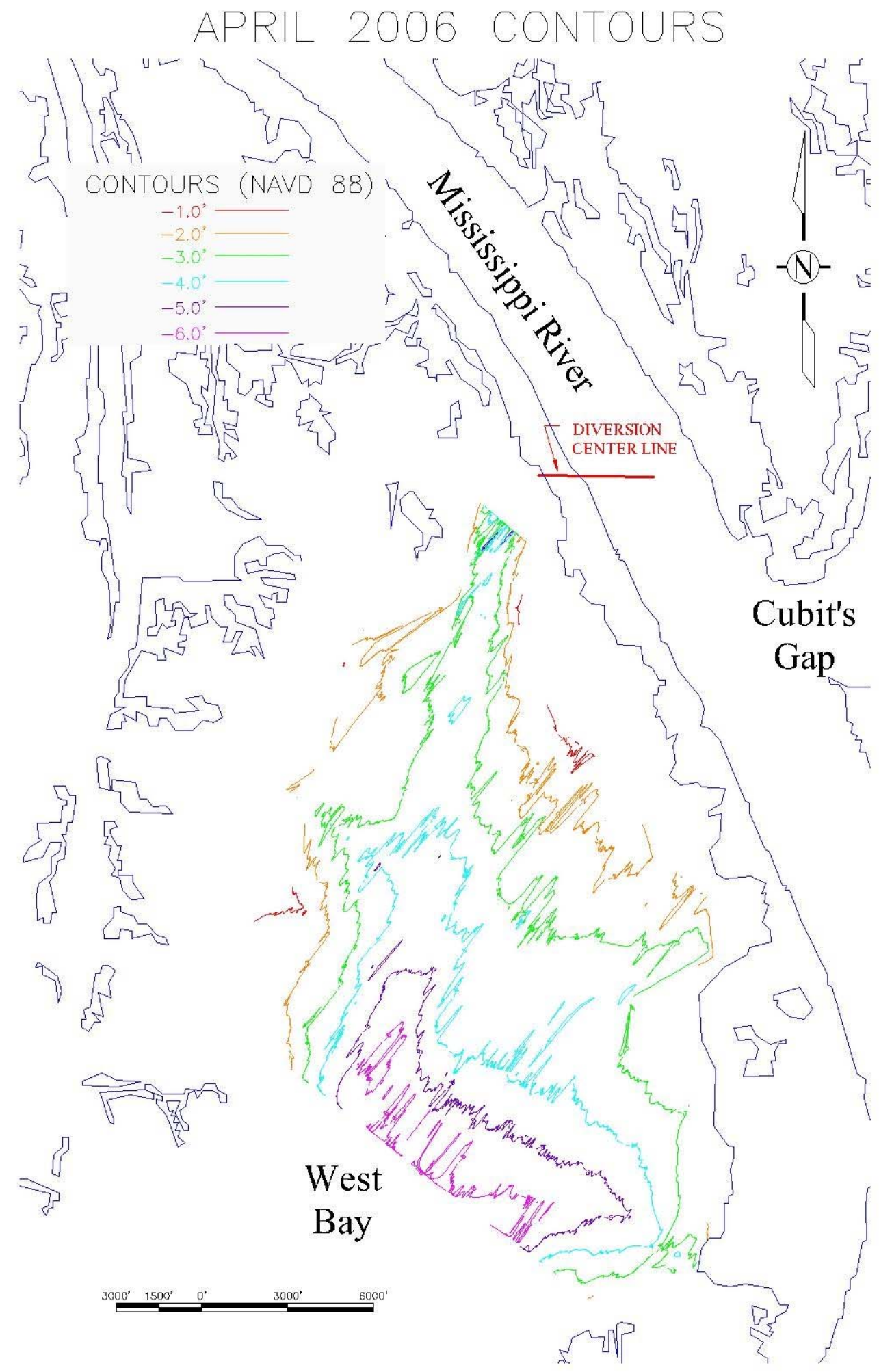

Figure 3-27. Post-construction Bathymetric Contours Measured in April 2006 


\subsection{Mississippi River Hydraulics}

Historical Mississippi River flow records and sediment loads were obtained from the USGS from the Tarbert Landing data collection station for the period of October 1977 through September 2006. These data were analyzed for yearly flow patterns and sediment concentrations of both fine and coarse loads.

\subsubsection{River Hydrograph}

River flows presented in Figure 3-28 ranged from lows of approximately 200,000 $\mathrm{ft}^{3} / \mathrm{s}$ $\left(5,600 \mathrm{~m}^{3} / \mathrm{s}\right)$ to peaks of approximately 1,400,000 $\mathrm{ft}^{3} / \mathrm{s}\left(39,600 \mathrm{~m}^{3} / \mathrm{s}\right)$ during 1977 to 2006 time frame. This data set was also used to create an average yearly hydrograph over the same time period which is presented in Figure 3-29. The average peak flow is approximately 775,000 $\mathrm{ft}^{3} / \mathrm{s}$

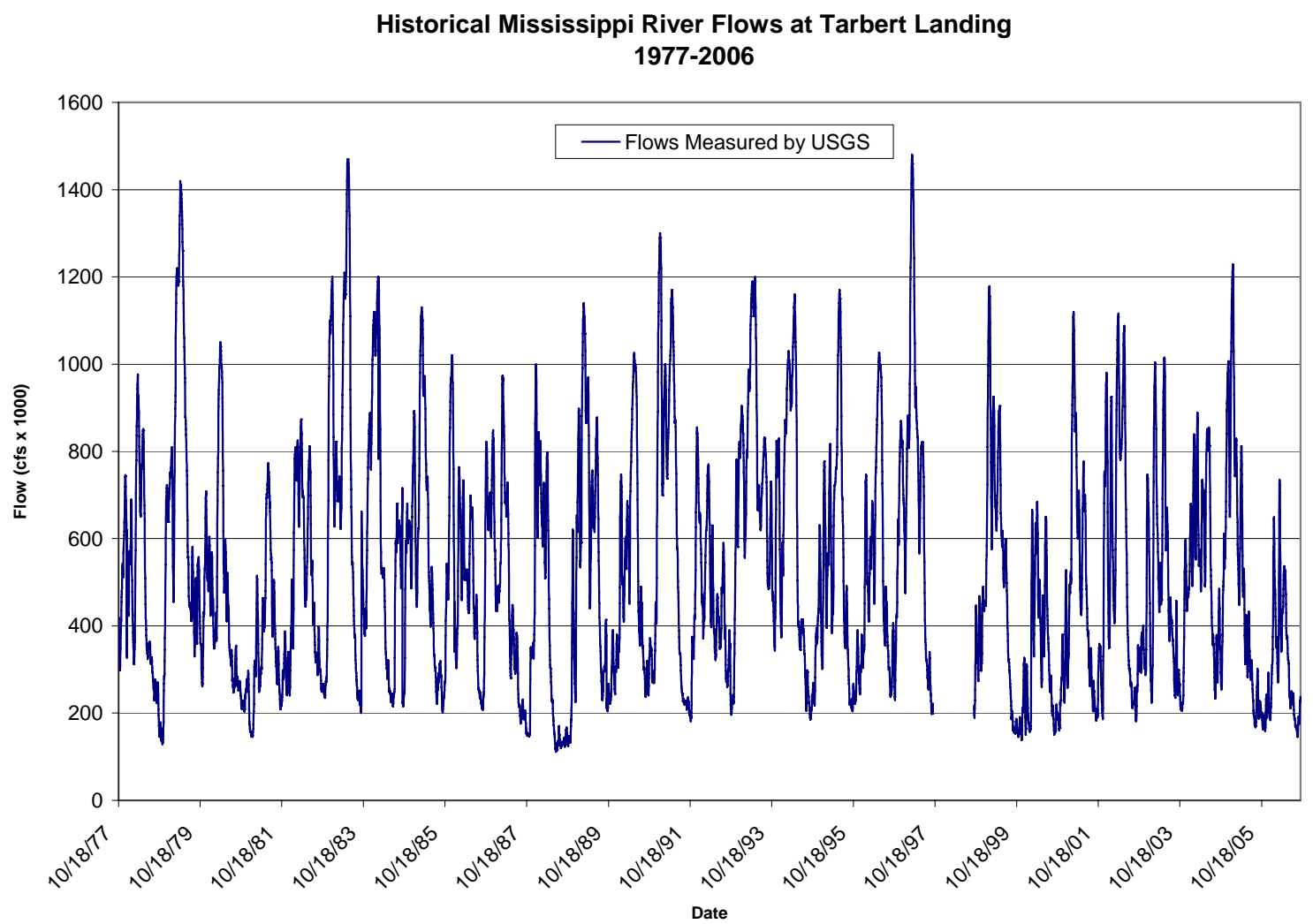

Figure 3-28. Historical Mississippi River Flows at Tarbert Landing from 1977 to 2006 
$\left(22,000 \mathrm{~m}^{3} / \mathrm{s}\right)$ and occurs in the spring between March and April. The average low flow is approximately 250,000 $\mathrm{ft}^{3} / \mathrm{s}\left(7,000 \mathrm{~m}^{3} / \mathrm{s}\right)$ and occurs in the Fall between September and October.

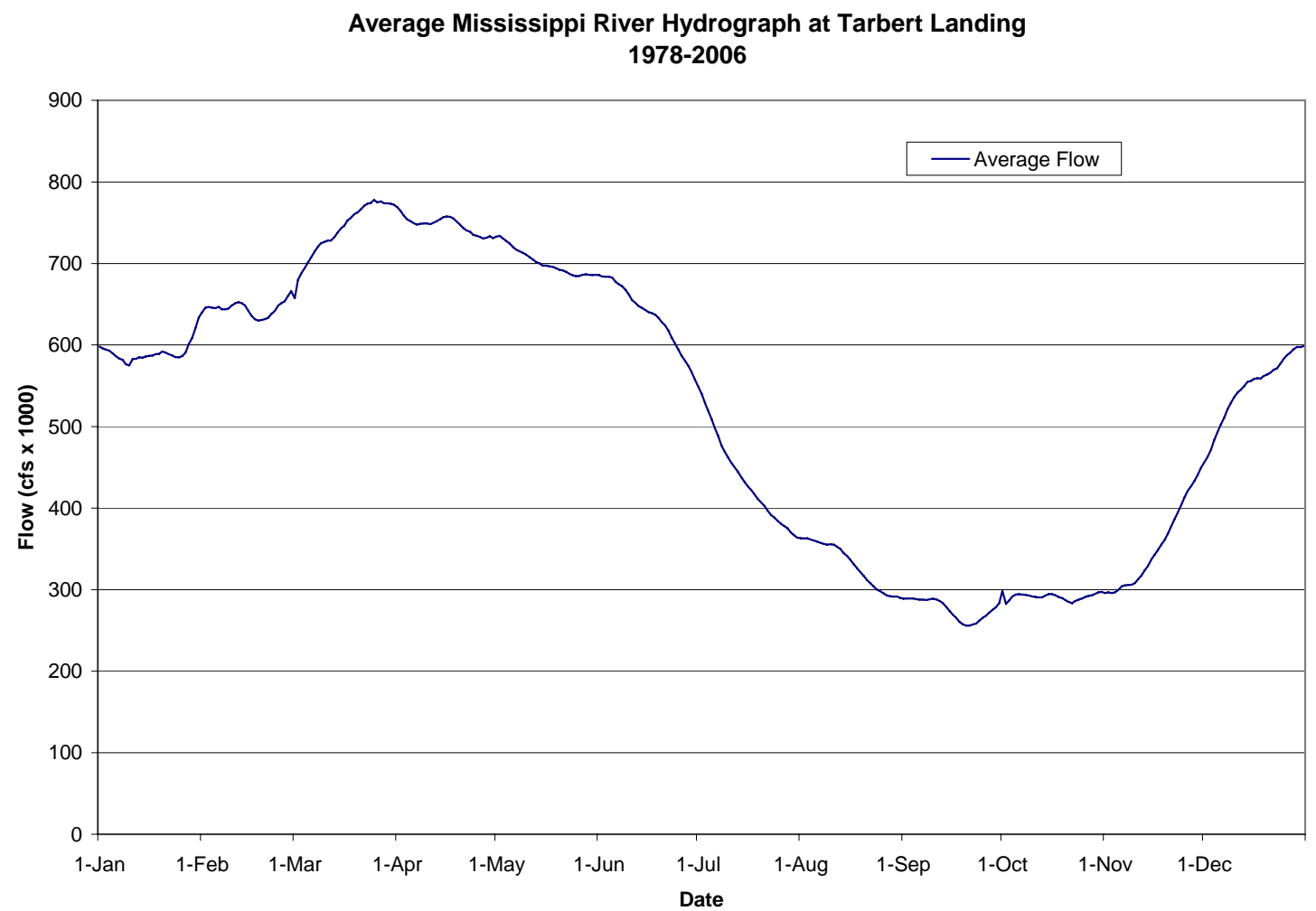

Figure 3-29. Average Mississippi River Yearly Hydrograph at Tarbert Landing

\subsubsection{Sediment Loads}

Suspended sediment concentrations are collected at Tarbert Landing typically two to three times per month by the USACE and USGS. The results from 1977 to 2006 presented in Figure 3-30 ranged from lows of approximately $100 \mathrm{ppm}$ and to peak concentrations ranging from $400 \mathrm{ppm}$ to $1000 \mathrm{ppm}$.

Figure 3-31 presents fine and coarse portions of the suspended sediment loads. Fines are considered to be grain sizes of less than $.0625 \mathrm{~mm}$ in diameter while coarse portions are greater than or equal to $.0625 \mathrm{~mm}$. On average, fines make up $83 \%$ of the total suspended sediment load while coarse sediments comprise $17 \%$. 


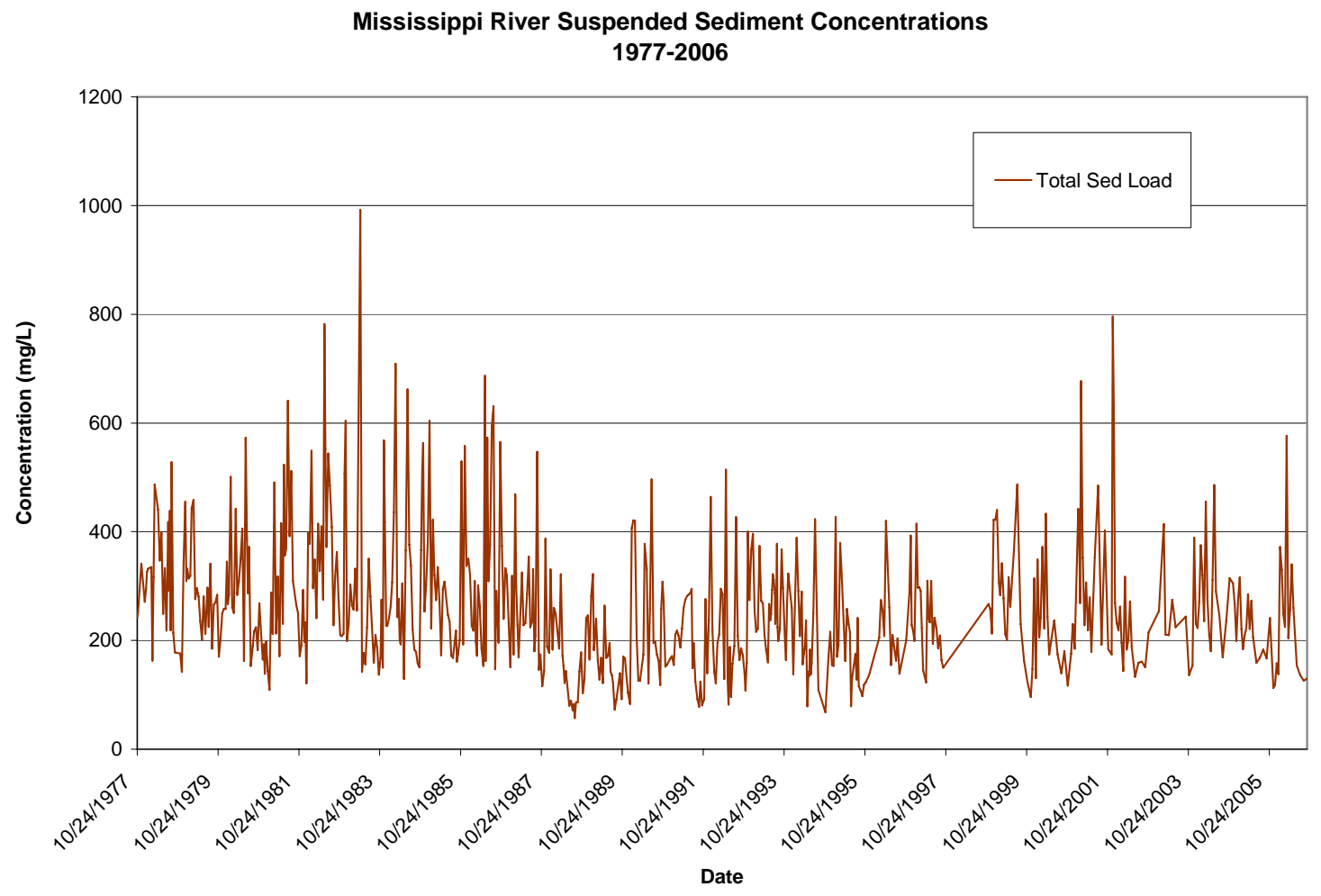

Figure 3-30. Mississippi River Suspended Sediment Concentrations from 1977 to 2006

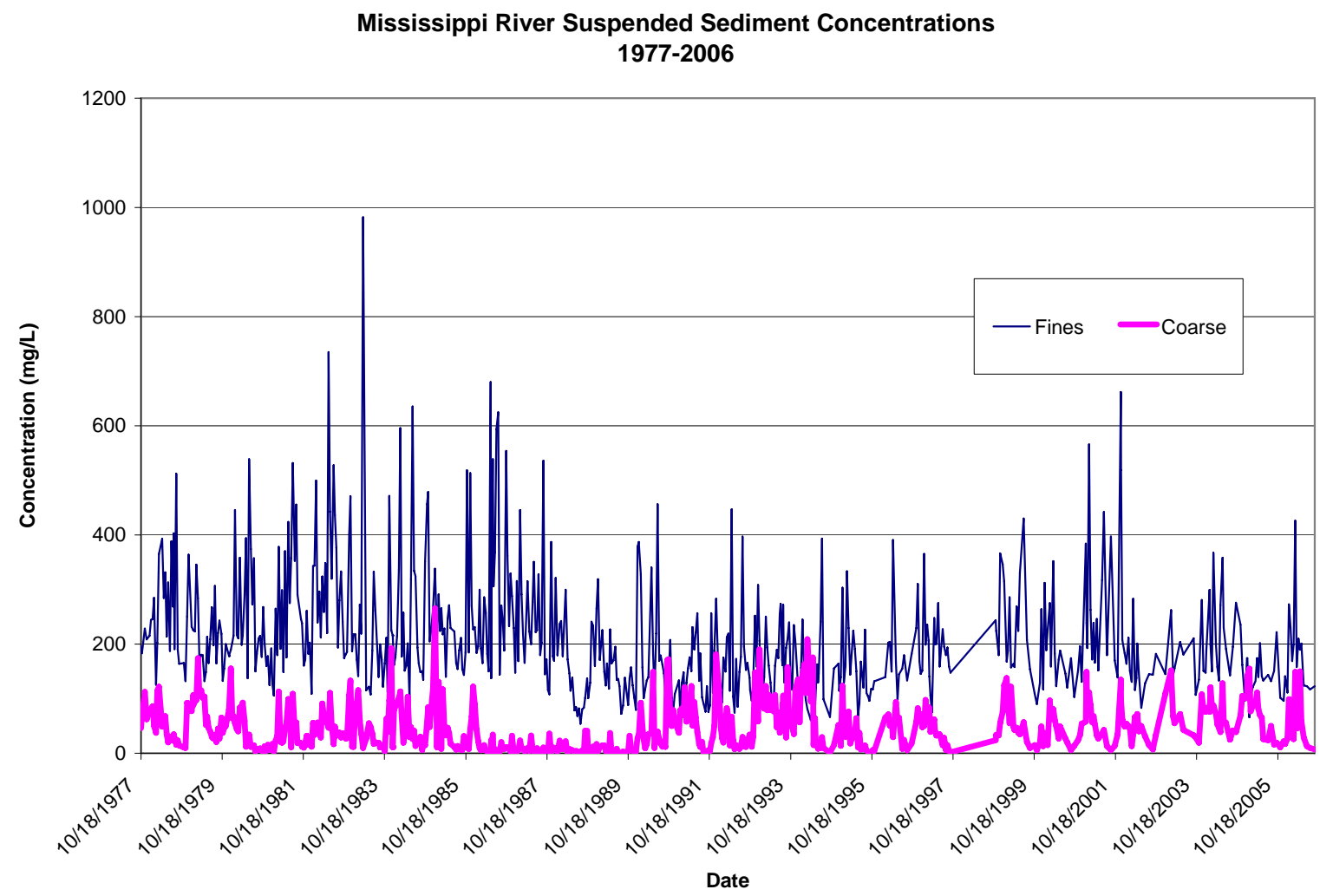

Figure 3-31. Coarse and Fine Mississippi River Sediment Loads at Tarbert Landing 
Sediment concentrations and percentages for fine and coarse portions were averaged on a monthly basis and plotted with the average yearly hydrograph in Figures 3-32 and 3-33, respectively. Concentrations of fine sediment average approximately $225 \mathrm{ppm}$ from January to June and peak in July at just over 250 ppm. After this peak, the concentration of fines drops sharply to below 200 ppm until December when the average hydrograph begins to rise again. Coarse sediment concentrations follow the average hydrograph more closely than fines, with peak concentrations of approximately $70 \mathrm{ppm}$ coinciding with peak flows in the Spring and minimum concentrations of approximately 20 ppm coinciding with minimum flows in the Fall. In general, at higher river flows, coarse sediments make up a higher percentage of the sediment load while fine sediments are at higher percentages during lower river flows.

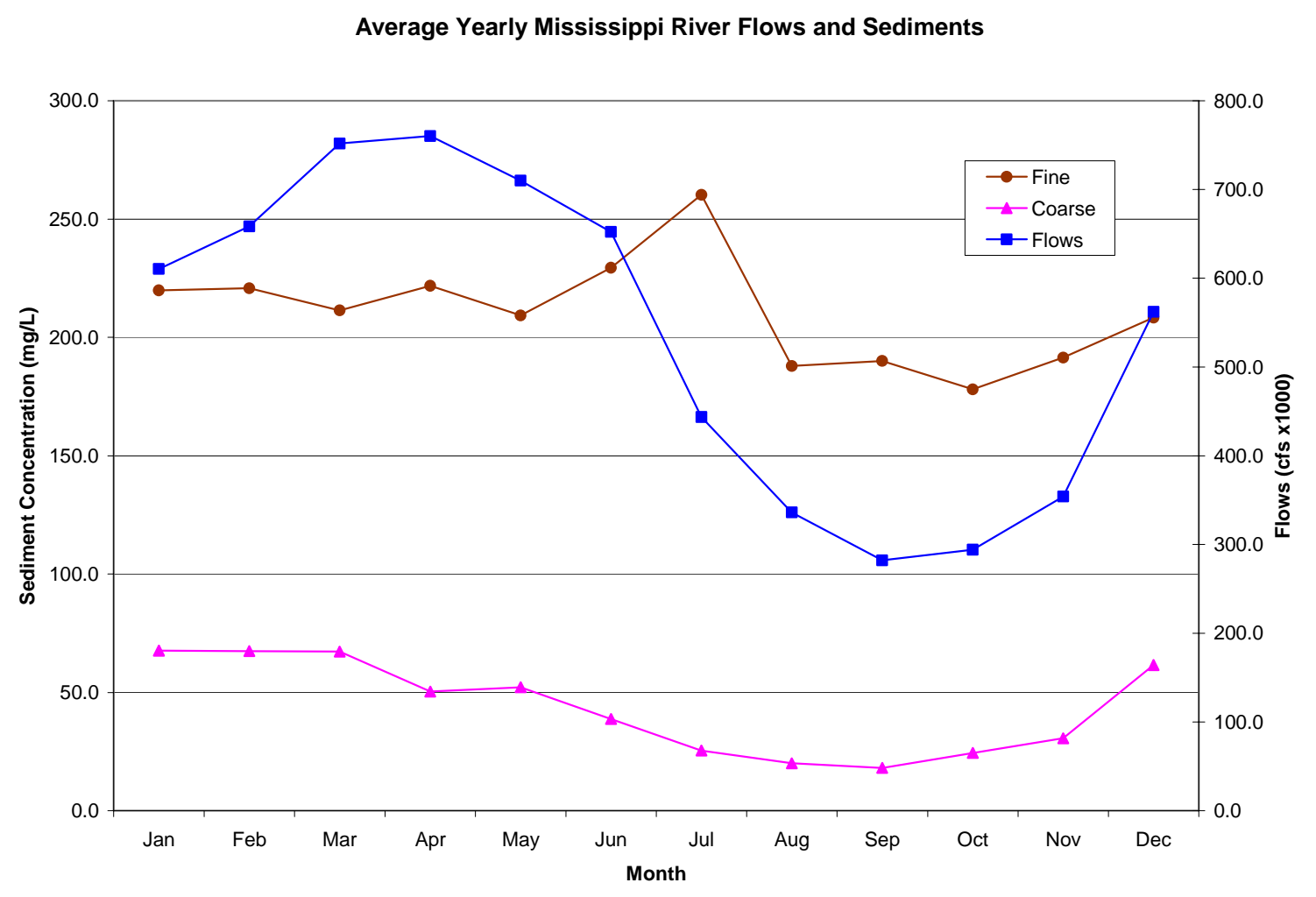

Figure 3-32. Yearly Averages of Flows and Sediment Concentrations at Tarbert Landing 


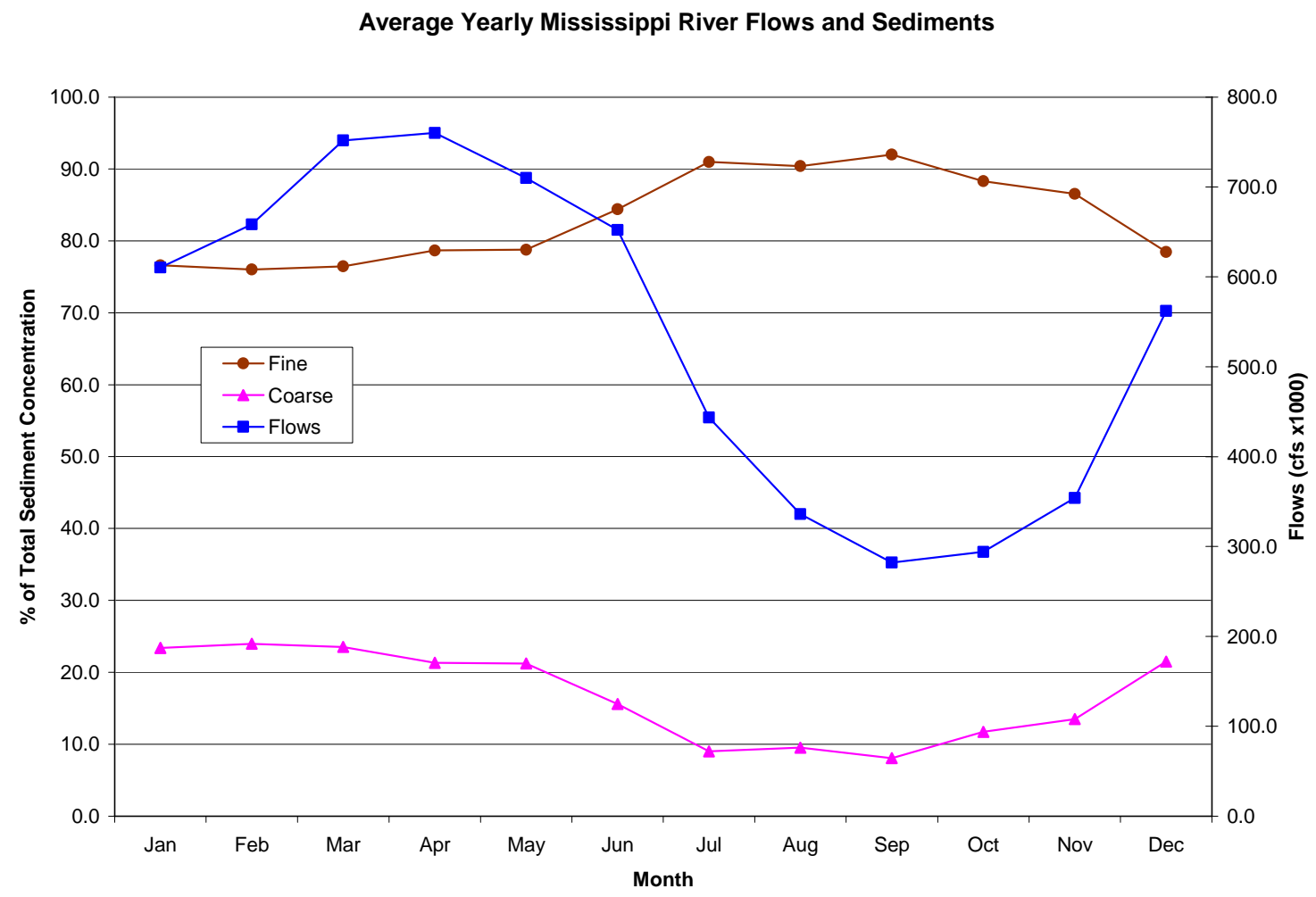

Figure 3-33. Yearly Averages of Flows and Sediment Percentages at Tarbert Landing

Presented in Figures 3-34 and 3-35 are X-Y scatter plots that relate sediment concentrations to river flow for fine and coarse fractions, respectively. Linear regression trend lines (red) and $\mathrm{R}^{2}$ values were added to the plots to convey the degree of dependency of sediment concentration to river flow. The $\mathrm{R}^{2}$ value for the fine concentrations is 0.0034 indicating a high degree of variability and little to no relationship between river flow and amount of fine suspended sediments. This is likely because finer particles rarely settle out of suspension in the main river channel even at lower velocities. Because the linear regression was such a poor fit, a polynomial regression trend line (green) was also added and resulted in an $\mathrm{R}^{2}$ value of 0.1051. This polynomial regression shows peak fine sediment concentrations at medium flows of approximately $600,000 \mathrm{ft}^{3} / \mathrm{s}\left(17,000 \mathrm{~m}^{3} / \mathrm{s}\right)$ (still accounts for only $\sim 10 \%$ of variability). 
Fine Sediment Concentrations

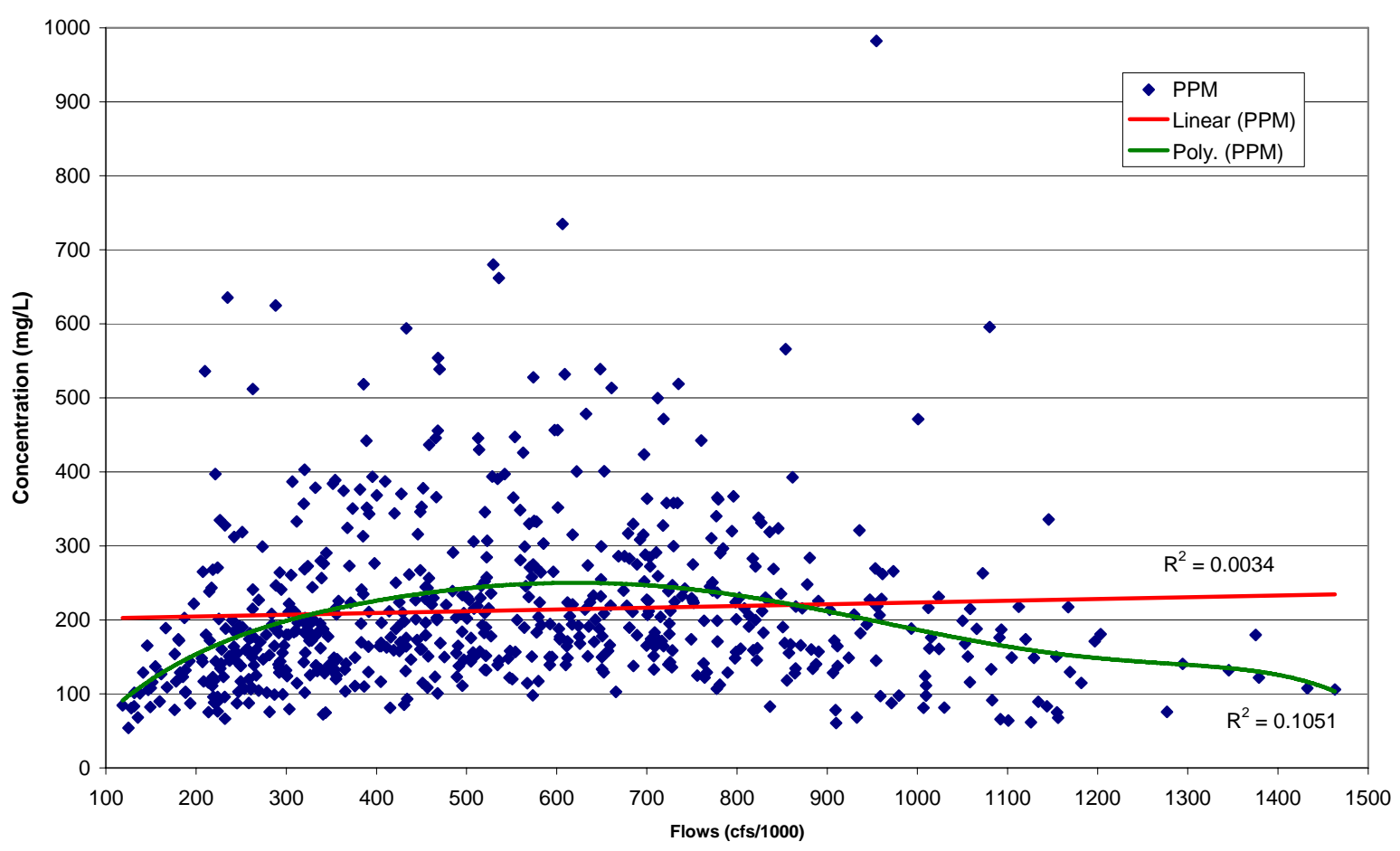

Figure 3-34. Fine Sediment Concentration vs. River Flow at Tarbert Landing Coarse Sediment Concentrations

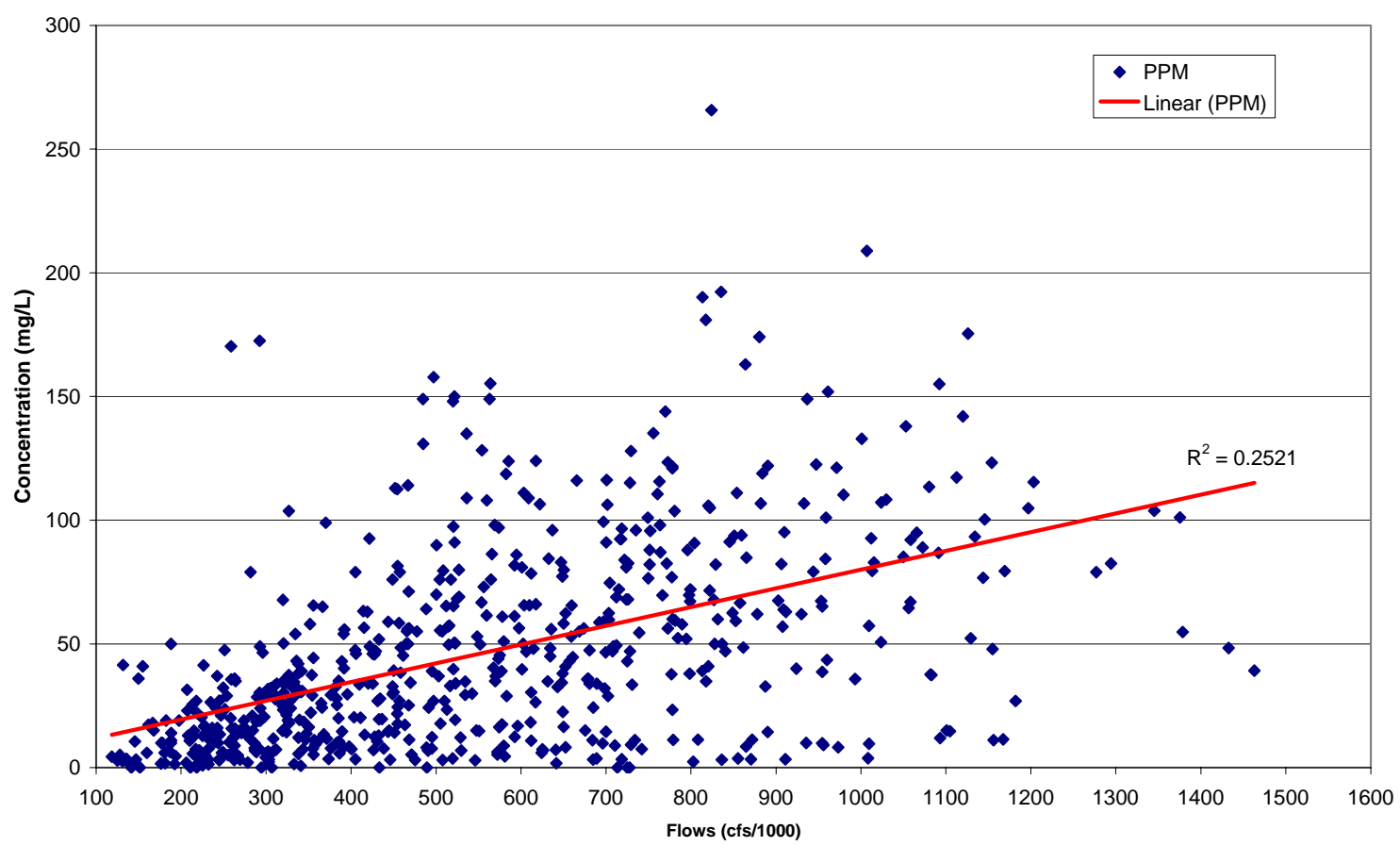

Figure 3-35. Coarse Sediment Concentration vs. River Flow at Tarbert Landing 
The relationship between coarse sediment concentrations and river flow corresponds better than for the fine sediment fraction. This is demonstrated by $\mathrm{R}^{2}$ value of 0.2521 shown in Figure 3-35. While there is still a considerable degree of variability, a general trend of increasing coarse sediment concentration with increasing river flows is evident.

Similar measurements were made by USGS in the Mississippi River downstream from Tarbert Landing at Belle Chase, LA between 1976 and 1998. River flows and sediment loads are presented in Figures 3-36 and 3-37, respectively. Flows ranged from lows of approximately $200,000 \mathrm{ft}^{3} / \mathrm{s}\left(5,600 \mathrm{~m}^{3} / \mathrm{s}\right)$ to highs of $1,000,000 \mathrm{ft}^{3} / \mathrm{s}\left(28,000 \mathrm{~m}^{3} / \mathrm{s}\right)$ and above. Concentrations of fine sediment average approximately $180 \mathrm{ppm}$ with a range of $5 \mathrm{ppm}$ to $600 \mathrm{ppm}$. Concentrations of coarse sediment average approximately $30 \mathrm{ppm}$ with a range of $0 \mathrm{ppm}$ to 170 ppm.

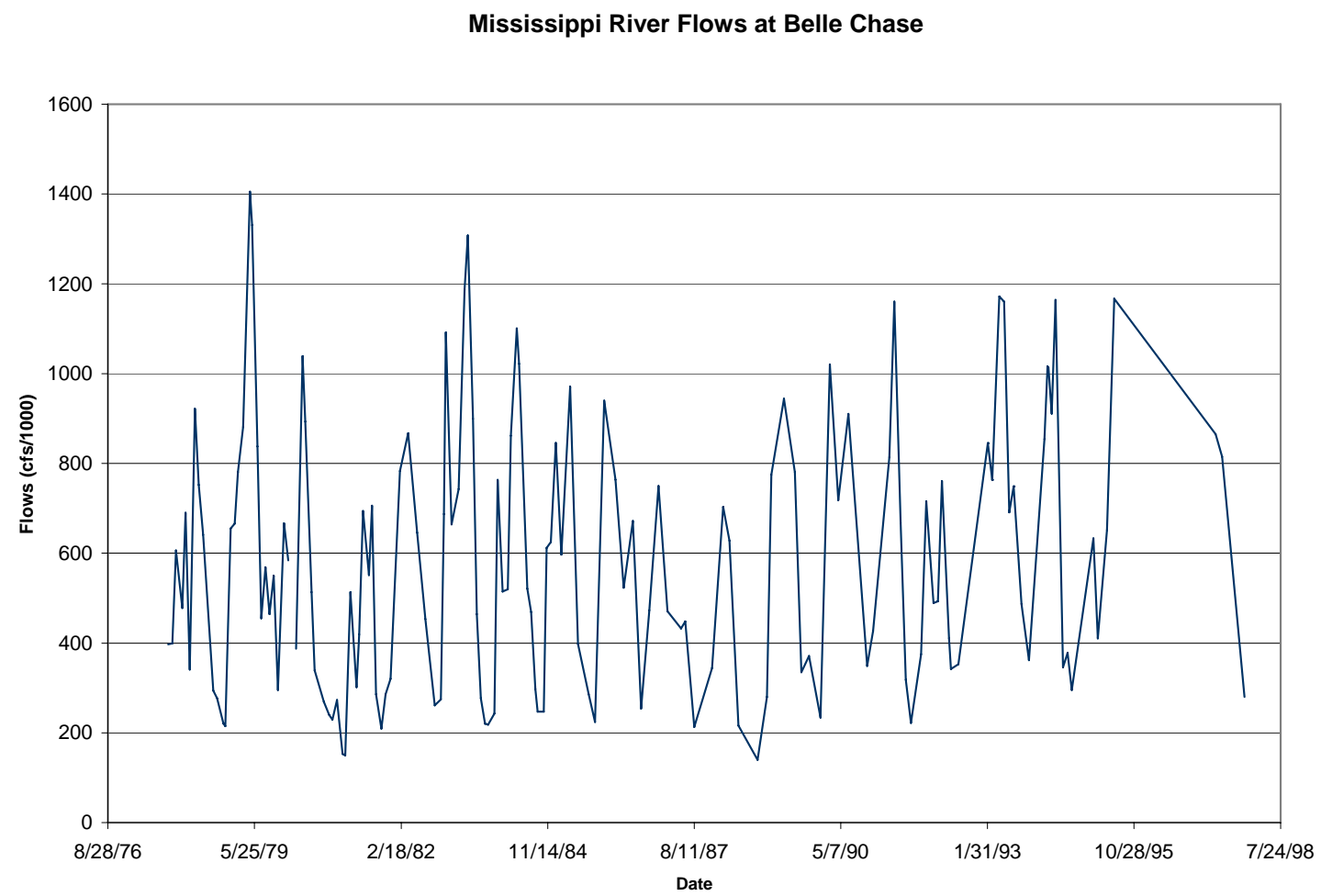

Figure 3-36. Mississippi River Flows at Belle Chase, LA 


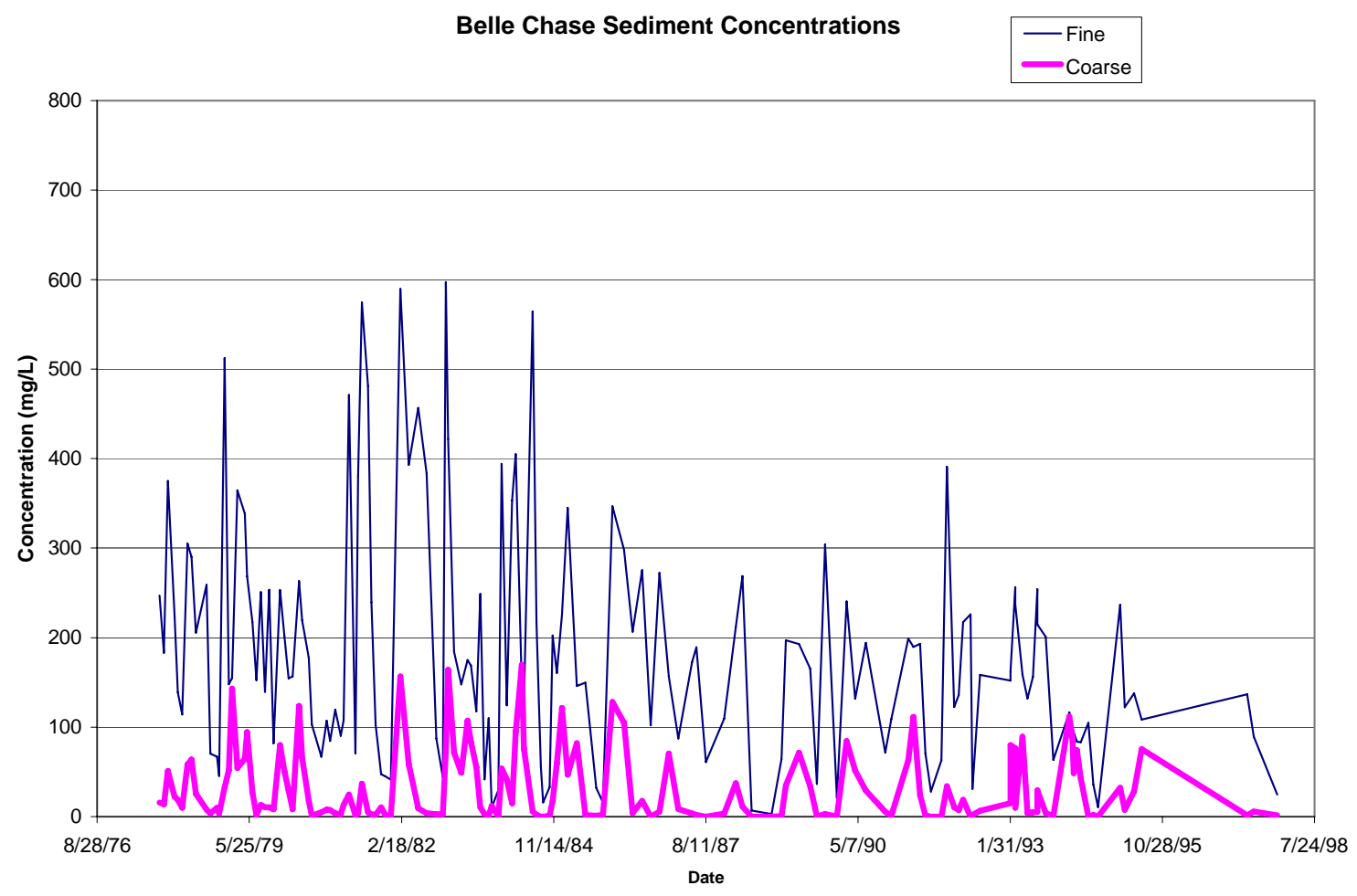

Figure 3-37. Coarse and Fine Mississippi River Sediment Loads at Belle Chase, LA

\subsection{Diversion Hydraulics}

\subsubsection{USACE Flow Measurements}

As part of the CWPPRA monitoring program, the USACE measures flows on a monthly basis within diversion and in the river just upstream of the diversion. Figures 3-38 and 3-39 are graphs of diversion flows and river flows above the diversion, respectively from December 2003 (1 month after diversion construction) to November 2006. Flows were not recorded from August 2005 to January 2006 because of restricted access to the area and limited resources available after Hurricanes Katrina and Rita.

While the flows from the diversion hydrograph are much lower in magnitude than the total river flow at this location, the hydrograph patterns of winter/early spring peaks and late summer lows are quite similar. This is further demonstrated by the X-Y scatter plot of diversion 
flow vs. river flow in Figure 3-40. The linear regression trend line has an $\mathrm{R}^{2}$ value of 0.5576 indicating a relatively strong correlation between river flow and diversion flow. As the diversion channel evolves and stabilizes this correlation should get stronger. Evidence of diversion channel enlargement through scour is seen as result of the Spring 2005 peak river discharge of approximately 750,000 $\mathrm{ft}^{3} / \mathrm{s}\left(21,200 \mathrm{~m}^{3} / \mathrm{s}\right)$ and corresponding peak diversion discharge of approximately $40,000 \mathrm{ft}^{3} / \mathrm{s}\left(1,100 \mathrm{~m}^{3} / \mathrm{s}\right)$. Before this peak, river flows of 350,000 to $500,000 \mathrm{ft}^{3} / \mathrm{s}$ (9,900 to $14,200 \mathrm{~m}^{3} / \mathrm{s}$ ) produced diversion flows of 5,000 to $15,000 \mathrm{ft}^{3} / \mathrm{s}\left(140\right.$ to $\left.425 \mathrm{~m}^{3} / \mathrm{s}\right)$. After this peak, river flows of 200,000 to $400,000 \mathrm{ft}^{3} / \mathrm{s}\left(5,600\right.$ to $\left.11,200 \mathrm{~m}^{3} / \mathrm{s}\right)$ produced diversion flows of 10,000 to $25,000 \mathrm{ft}^{3} / \mathrm{s}\left(280\right.$ to $\left.710 \mathrm{~m}^{3} / \mathrm{s}\right)$. It is also noteworthy that at the lowest river flow reached during the two year period was approximately 100,000 $\mathrm{ft}^{3} / \mathrm{s}\left(2,800 \mathrm{~m}^{3} / \mathrm{s}\right)$ which coincides with negative diversion flows (flow from West Bay into the river).

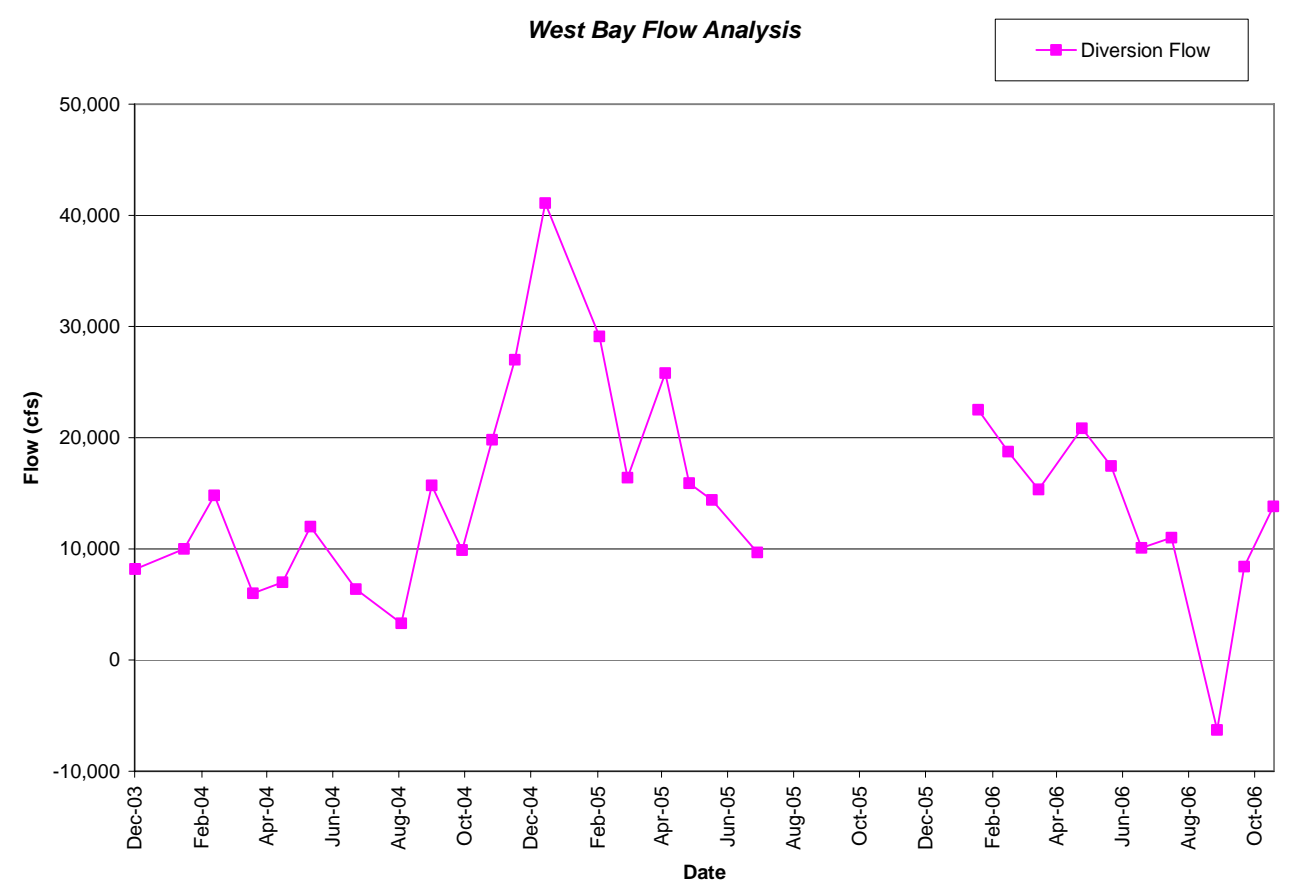

Figure 3-38. Measured Diversion Flows from Dec. ’03 to Nov. '06 


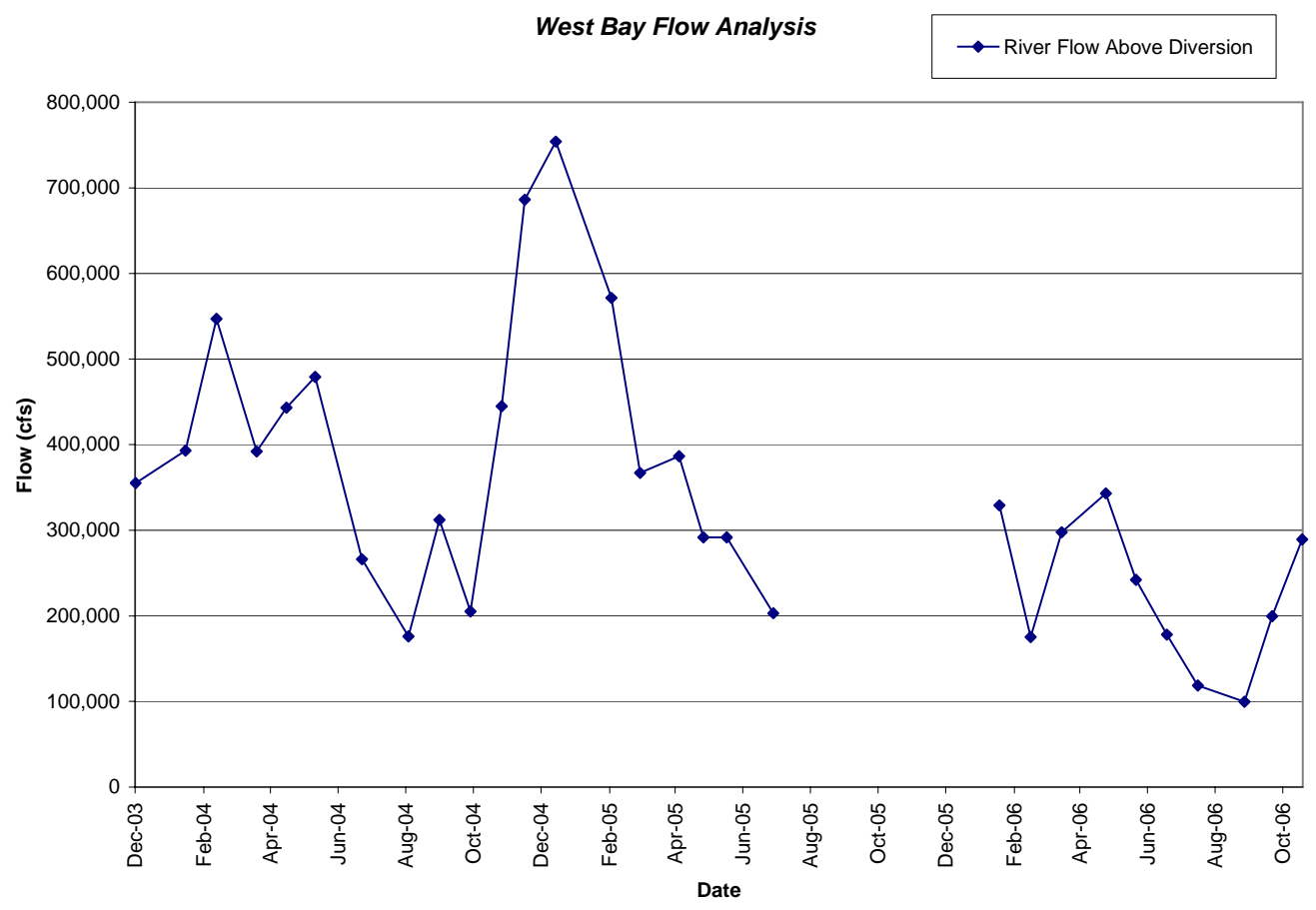

Figure 3-39. Measured River Flows Upstream of Diversion from Dec. '03 to Nov. '06

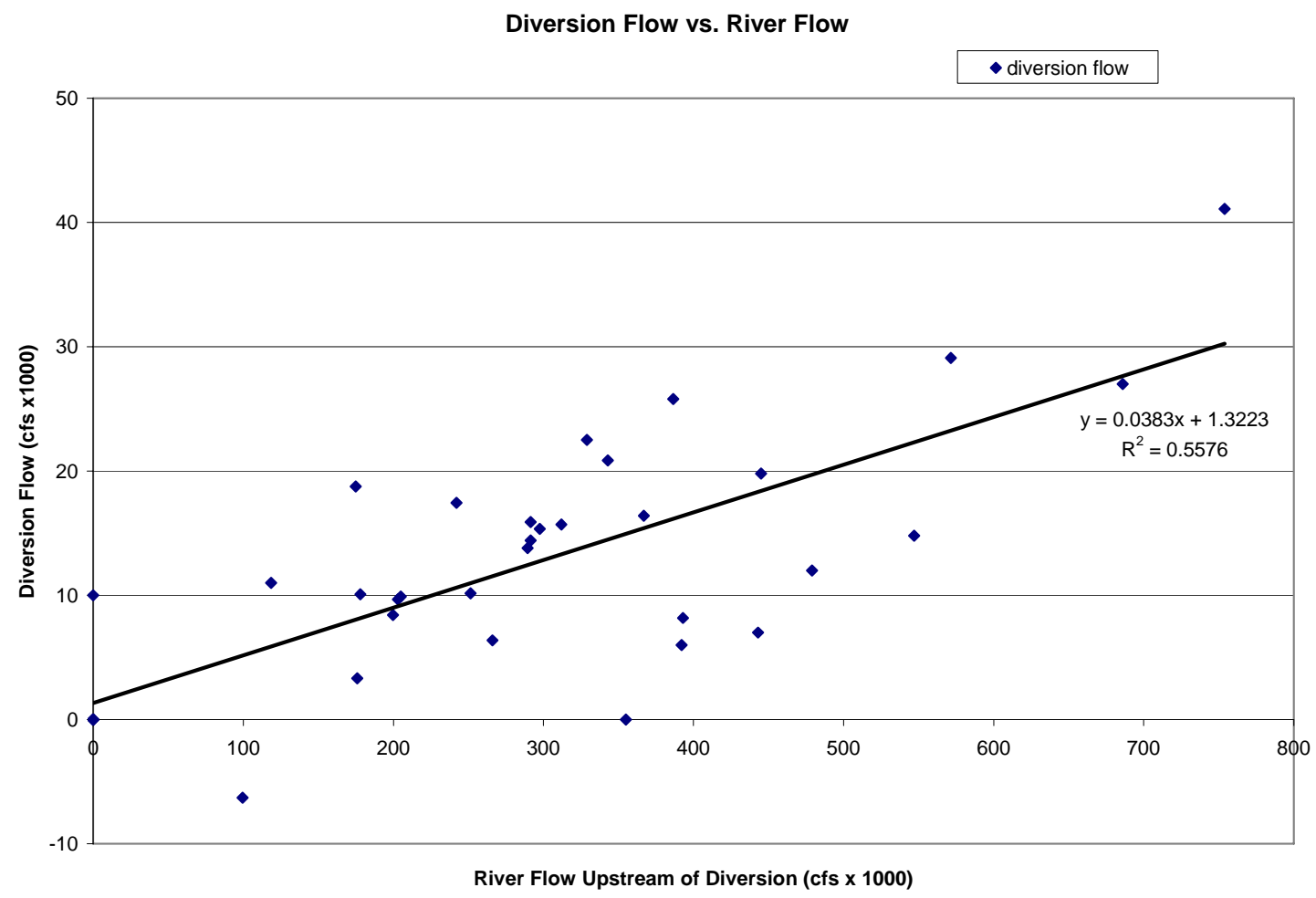

Figure 3-40. Diversion Flows vs. River Flows 


\subsubsection{LSU CSI Flow Measurements}

Using methods and instrumentation discussed in Section 2.3.1, velocities were collected by LSU-CSI in the diversion cut for one month from February 8, 2006 to March 7, 2006. These velocity data were used along with the cross sectional area of the diversion cut at the instrument location. The cross section shown in Appendix G was used for this calculation.

Because the fixed position ADCP measured velocities only up to $17.2 \mathrm{ft}$ (5.23 m) away from the instrument, an additional flow study was conducted to collect simultaneous velocity measurements at various locations and depths in the cut to acquire a more detailed velocity distribution across the diversion at this cross section. A boat mounted ADCP was used to acquire these additional velocity measurements at three lateral positions along the cross section with multiple depth locations at each position. The velocity data at each one of these positions was compared to the corresponding velocity measured at the fixed ADCP and used to calculate a correction factor for each position. An individual cross sectional area was also calculated for each of the positions and multiplied by the corrected velocities over the entire data set. Average daily flows for each position were summed to arrive at a diversion flow rate for each day during the month of collection.

These average daily flows are presented in Figure 3-41. Flows ranged from 16,000 to $30,000 \mathrm{ft}^{3} / \mathrm{s}$ (450 to $850 \mathrm{~m}^{3} / \mathrm{s}$ ) with most values falling between 20,000 and 25,000 $\mathrm{ft}^{3} / \mathrm{s}$ (560 to $710 \mathrm{~m}^{3} / \mathrm{s}$ ). On February 16, 2006 the USACE measured the diversion flow to be $22,500 \mathrm{ft}^{3} / \mathrm{s}$ $\left(640 \mathrm{~m}^{3} / \mathrm{s}\right)$ while the LSU-CSI study measured $24,660 \mathrm{ft}^{3} / \mathrm{s}\left(700 \mathrm{~m}^{3} / \mathrm{s}\right)$. This is a 2,160 $\mathrm{ft}^{3} / \mathrm{s}(60$ $\mathrm{m}^{3} / \mathrm{s}$ ) or $9.6 \%$ difference which is considered to be a good comparison given the environmental variables associated with the physical measurements. The average flow over the entire dataset was $22,976 \mathrm{ft}^{3} / \mathrm{s}\left(650 \mathrm{~m}^{3} / \mathrm{s}\right)$. 


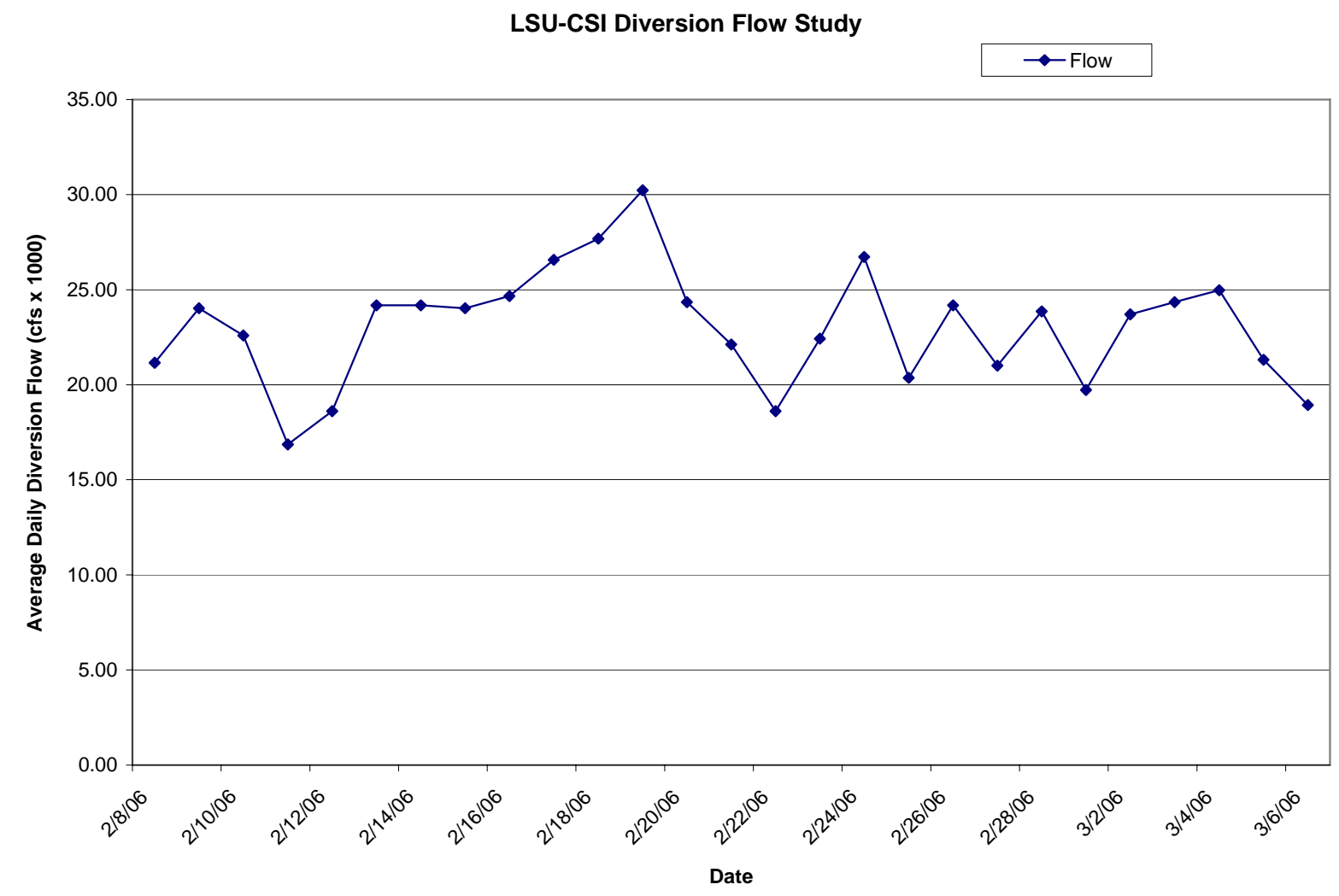

Figure 3-41. Hydrograph Results from LSU-CSI Flow Study in the Diversion Cut

\subsubsection{Turbidity Measurements}

Using methods and instrumentation described in Section 2.3.1, turbidity measurements were taken in the diversion cut at the same location and during the same time period as the velocity measurements. Turbidity was measured in nephelometric turbidity units (NTU) which is a measurement of optical backscatter or the scattering of light through water caused by materials in suspension or solution. The suspended and dissolved material can include clay, silt, finely divided organic and inorganic matter, soluble organic compounds, and plankton and other microscopic organisms. Figure 3-42 is a graph of turbidity measured in the diversion cut from February 8, 2006 to March 7, 2006. 


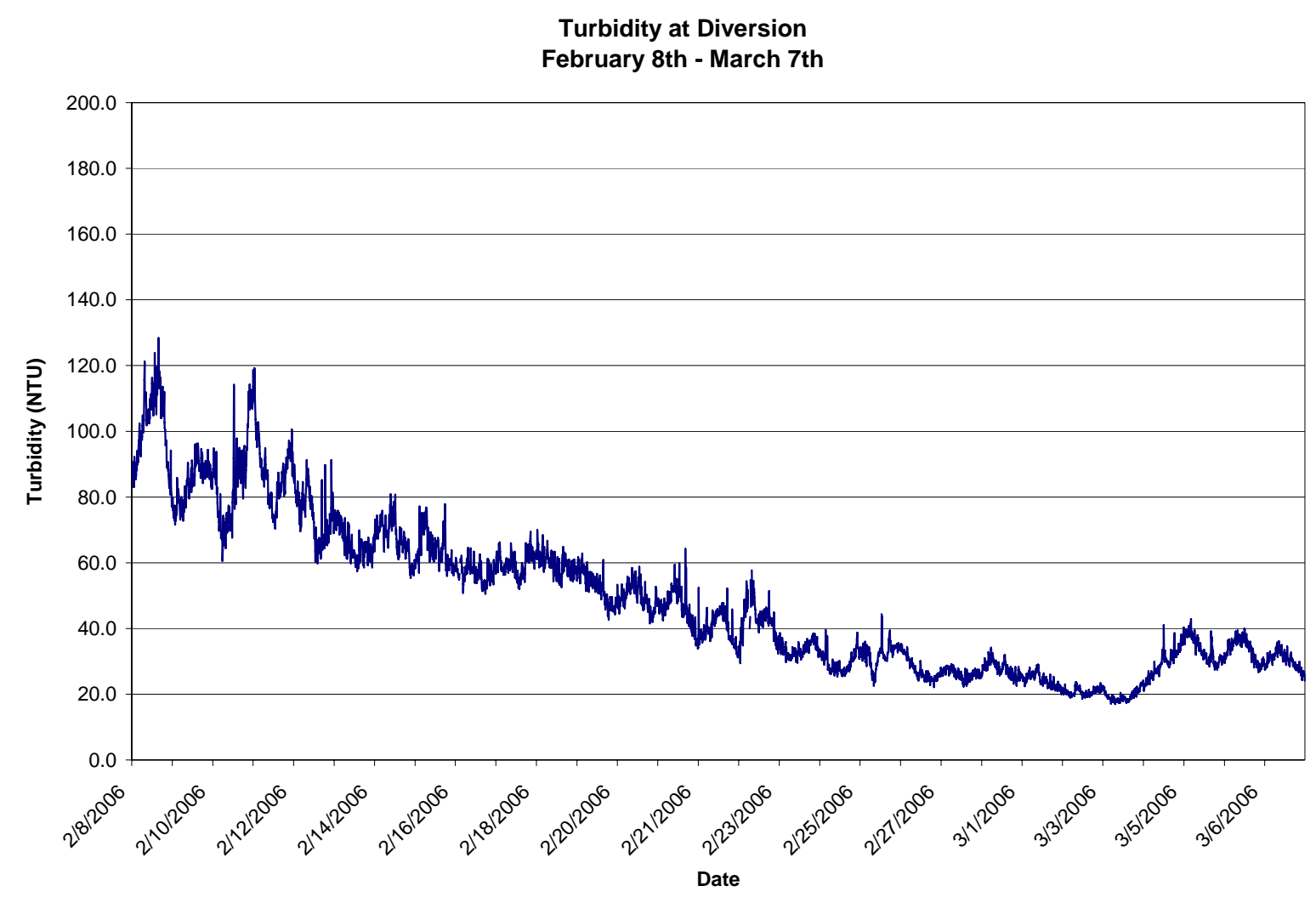

Figure 3-42. Turbidity Results from LSU-CSI Study in the Diversion Cut

For this study, the contribution of inorganic material, clay and silt in particular, on turbidity is of the most interest. To determine the effect of inorganic materials on turbidity measurements, a laboratory calibration of the turbidity sensor was performed using known concentrations of suspended particulate matter (SPM). The calibration was run using three water samples from the project area and nine water samples of mixed de-ionized water and known quantities of fine sediment taken from sampled cores. Using the sensor from the field study, turbidity of the water samples was measured from a centrifuge to keep the sediments in suspension. Following this test a standard suspended particle matter analysis was performed on each water sample by filtering a known quantity of water and drying and weighing the filtered sediment. Quantities of organic materials were then determined by ashing the dried sediments in 
a furnace and weighing them again. The details of SPM calculations are included in Appendix F. Figure 3-43 shows these SPM results plotted against turbidity measurements made in the laboratory for calibration.

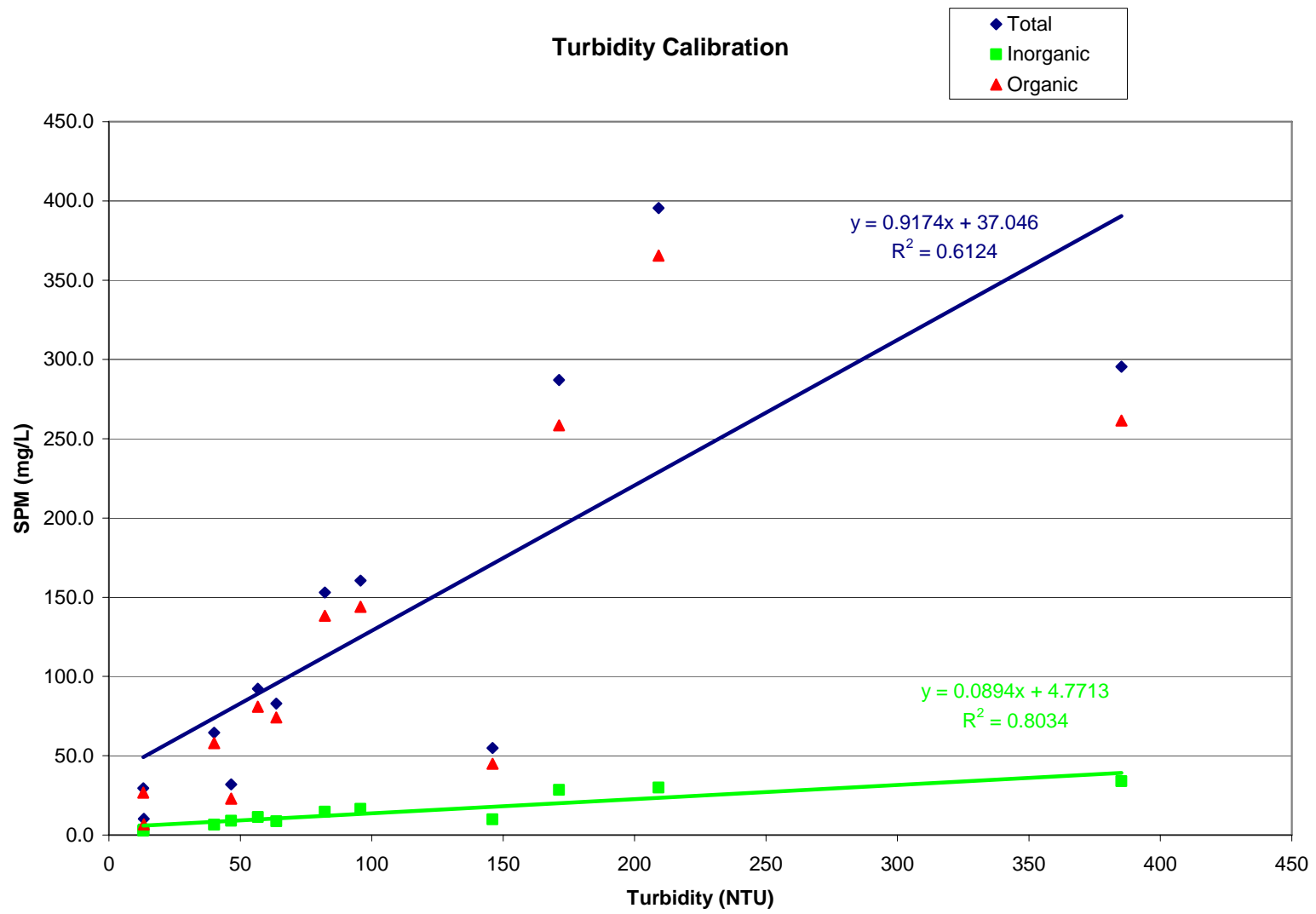

Figure 3-43. Calibration of Turbidity Sensor vs. Suspended Particle Matter (SPM)

The results of the calibration showed a relatively close relationship between total SPM and turbidity as indicated by an $\mathrm{R}^{2}$ value of 0.6124 . It is apparent that the majority of the total SPM is made up of organic material which is more variable than the inorganic percentage. Percentages of inorganic material ranged from $7.6 \%$ to $33.3 \%$ with an average of $14.3 \%$ and a standard deviation of 8.2. There is also a closer relationship between inorganic SPM and turbidity as indicated by an $\mathrm{R}^{2}$ value of 0.8034 . From the regression analyses, the equations of the linear trend lines yield the following relationships between turbidity and SPM: 
Total SPM $=0.9174 *$ turbidity +37.046

Inorganic SPM $=0.0894 *$ turbidity +4.7713

Estimates of total and inorganic SPM were calculated by applying equations 5 and 6 to the measured turbidity values. Figure 3-44 shows the results of these calculations as applied to month long data set collected at the diversion cut from February 8, 2006 to March 7, 2006. The estimations show that the pattern of total SPM tracks closely with turbidity, but inorganic SPM does not. Total SPM ranges from just above $150 \mathrm{mg} / \mathrm{L}$ to just below $60 \mathrm{mg} / \mathrm{L}$ with an average of $82 \mathrm{mg} / \mathrm{L}$ and a standard deviation of 21. Inorganic SPM ranges from just above $16 \mathrm{mg} / \mathrm{L}$ to just above $6 \mathrm{mg} / \mathrm{L}$ with an average of $9 \mathrm{mg} / \mathrm{L}$ and a standard deviation of 2 .

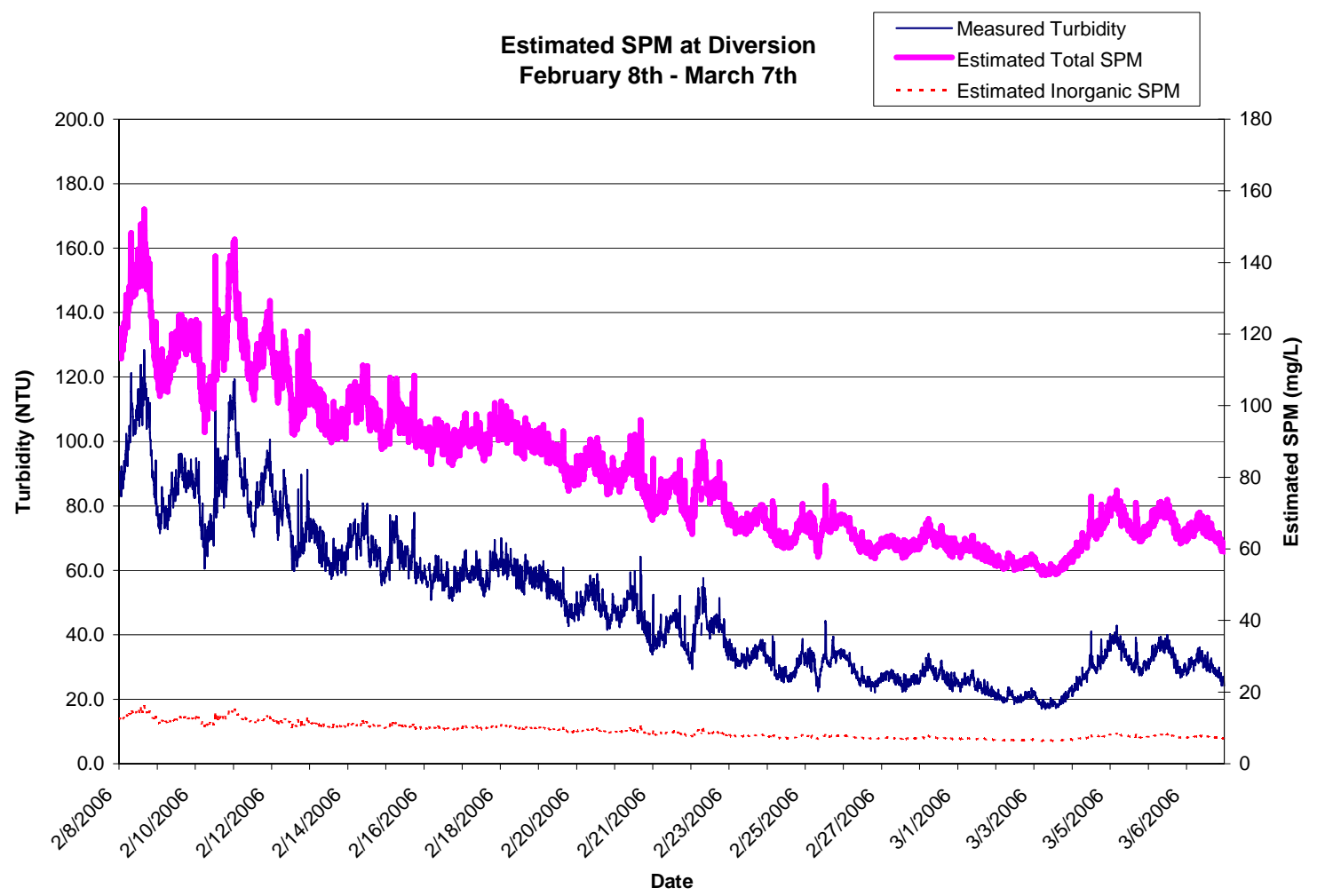

Figure 3-44. Estimated (SPM) in the Diversion Cut During LSU-CSI Flow Study 


\subsection{Bay Measurements}

\subsubsection{Turbidity Measurements}

Turbidity measurements were conducted at the mid-bay location between March 7, 2006 and April 14, 2006. Details of the instrument deployments are included in Section 2.3.1. Estimates of total and inorganic SPM were calculated by applying equations 5 and 6 to the measured turbidity values. Figure 3-45 shows the results of these calculations as applied to the field turbidity measurements. Total SPM ranges from just above $275 \mathrm{mg} / \mathrm{L}$ to just below 45 $\mathrm{mg} / \mathrm{L}$ with an average of $78 \mathrm{mg} / \mathrm{L}$ and a standard deviation of 30. Inorganic SPM ranges from 28 $\mathrm{mg} / \mathrm{L}$ to just above $5 \mathrm{mg} / \mathrm{L}$ with an average of $9 \mathrm{mg} / \mathrm{L}$ and a standard deviation of 3.

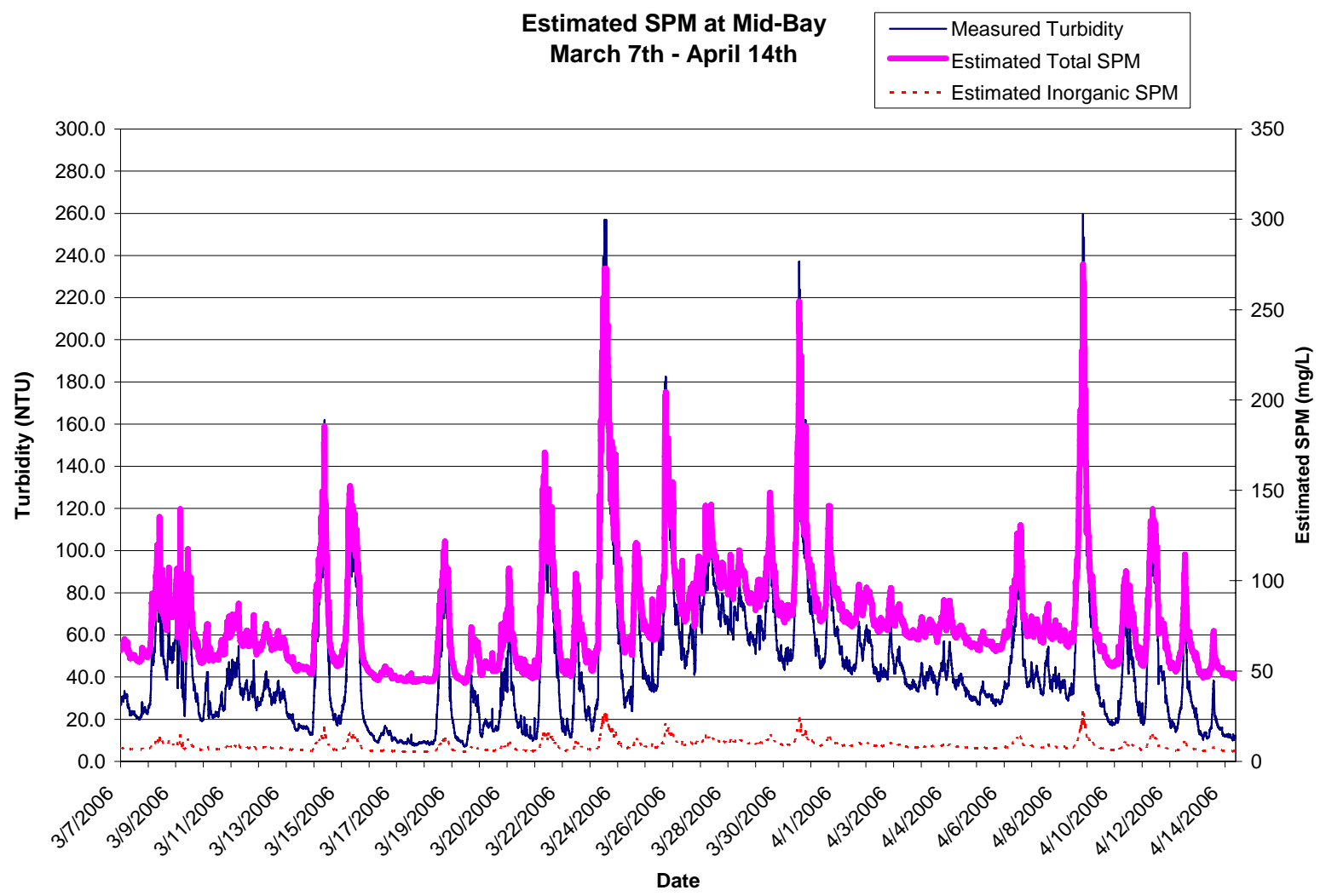

Figure 3-45. Estimated (SPM) at Mid-bay Site During LSU-CSI Bay Study 


\subsubsection{Velocity Measurements}

Velocity measurements were conducted at the mid-bay location between March 7, 2006 and March 15, 2006 and again between March 21, 2006 and April 4, 2006. Details of the instrument deployments and data collection methods are included in Section 2.3.1. Velocities were measured in two horizontal directions, $\mathrm{X}$ and $\mathrm{Y}$ with respect to instrument orientation measured by an internal compass. $\mathrm{X}$ and $\mathrm{Y}$ values were used to determine resultant horizontal velocity magnitudes and directions. Figures 3-46 and 3-47 display resultant horizontal velocities in feet per second and meters per second along with direction in degrees to the bearing shown for the first and second deployments, respectively.

\subsubsection{Tide Measurements}

Water depths were recorded during the instrument deployments at the mid-bay location and illustrated in Figure 3-48. The maximum diurnal tidal range measured was $2.5 \mathrm{ft}(0.8 \mathrm{~m})$ and the average tidal range was $0.9 \mathrm{ft}(0.3 \mathrm{~m})$. This data set was then compared to tidal measurements made at the diversion location shown in Figure 3-49. The maximum tidal range measured at the measured at the diversion was $1.9 \mathrm{ft}(0.6 \mathrm{~m})$ and the average tidal range was 0.6 $\mathrm{ft}(0.2 \mathrm{~m})$.

\subsubsection{Salinities}

Salinities were also recorded during the instrument deployments at the mid-bay location and illustrated in Figure 3-50. The maximum, minimum and average salinities measured were 8.81, 0.17, and 0.46 parts per thousand (ppt), respectively. The maximum, minimum and average salinities measured at the diversion were $0.45,0.17$, and $0.19 \mathrm{ppt}$, respectively. These values were recorded over very short time periods and should be used for relative comparison purposes within the study area only. One prolonged period of higher salinities occurred at the 

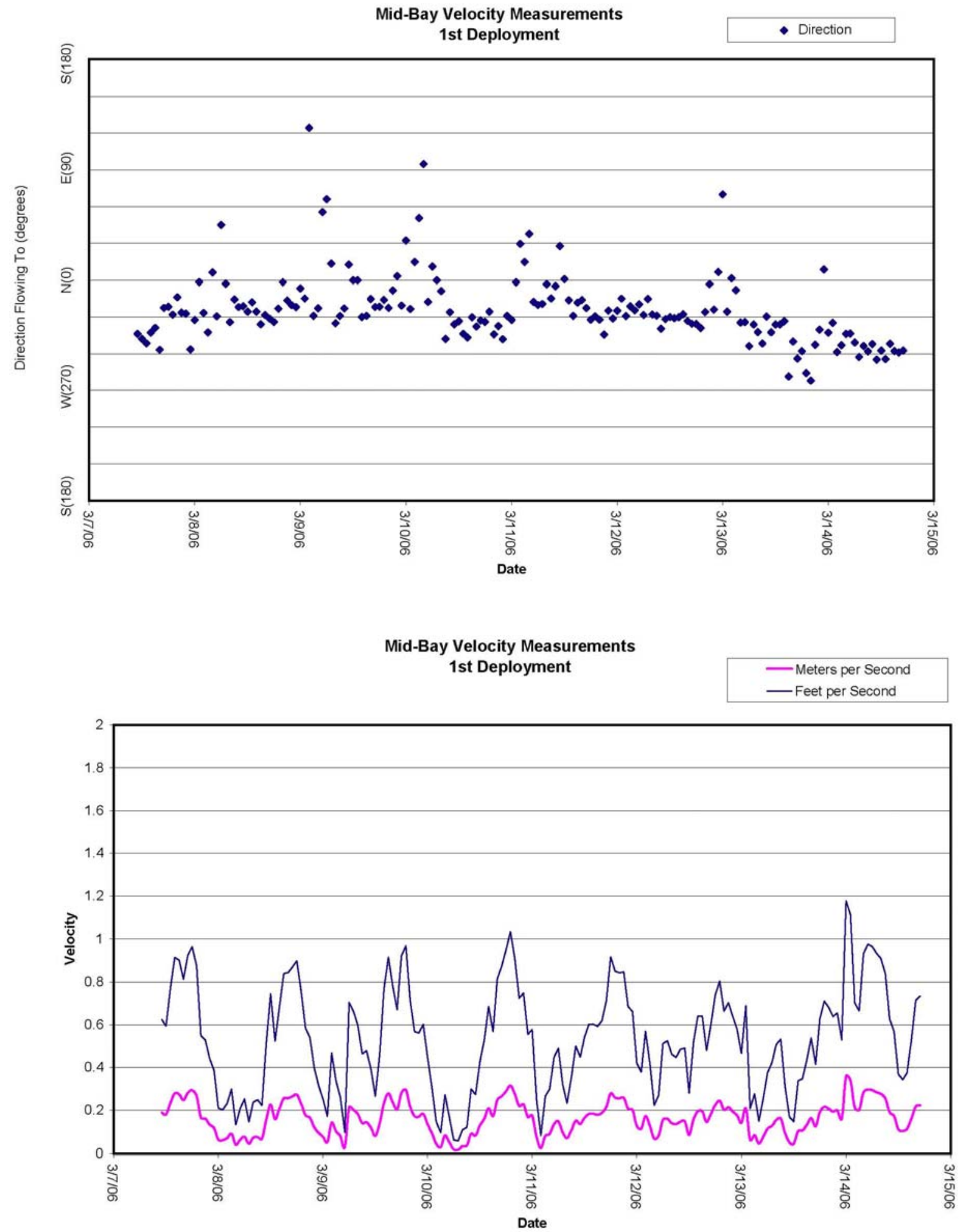

Figure 3-46. Velocity Measurements at Mid-bay Site During $1^{\text {st }}$ Deployment 

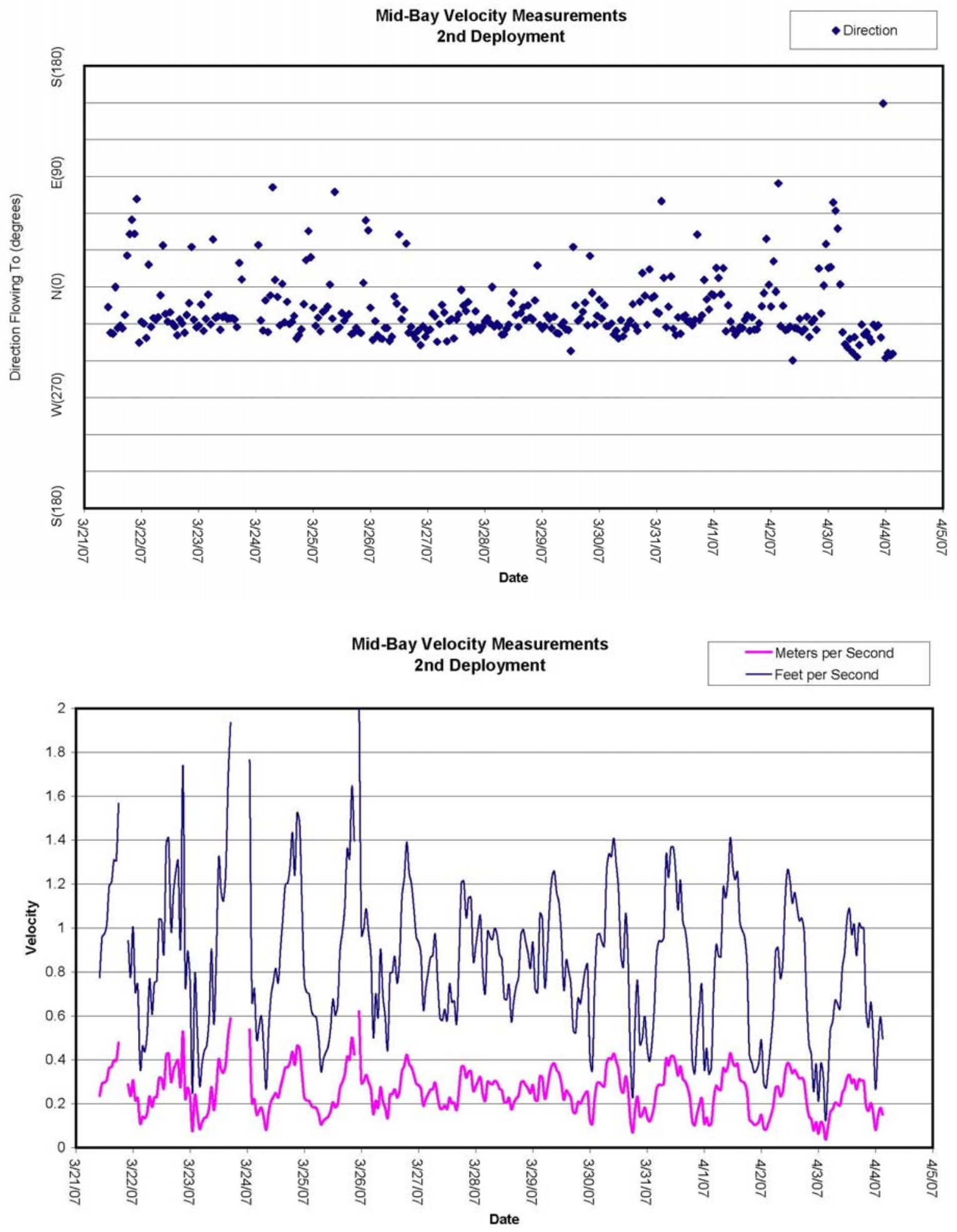

Figure 3-47. Velocity Measurements at Mid-bay Site During $2^{\text {nd }}$ Deployment 


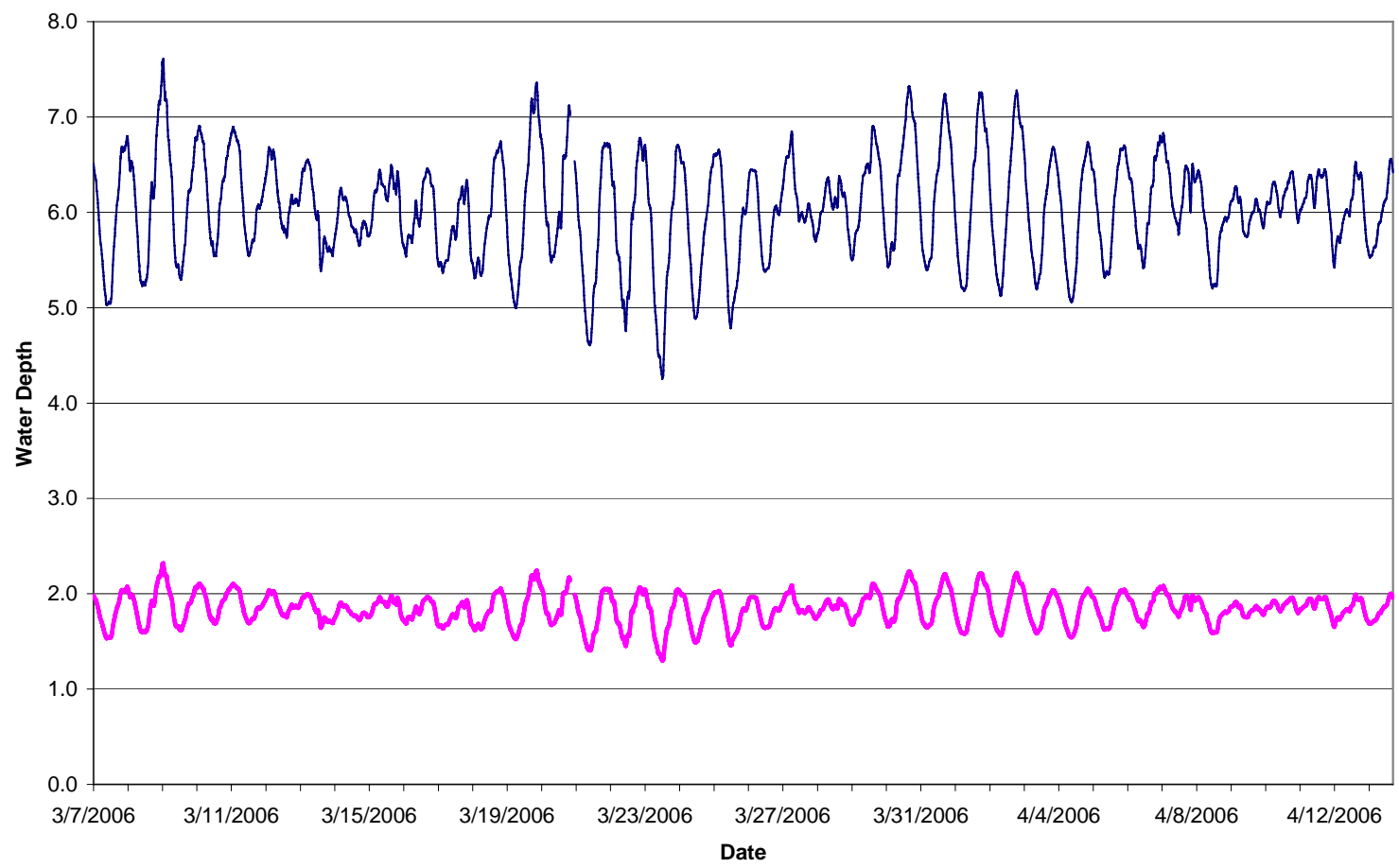

Figure 3-48. Water Depths Recorded at Mid Bay

Tidal Record at Diversion

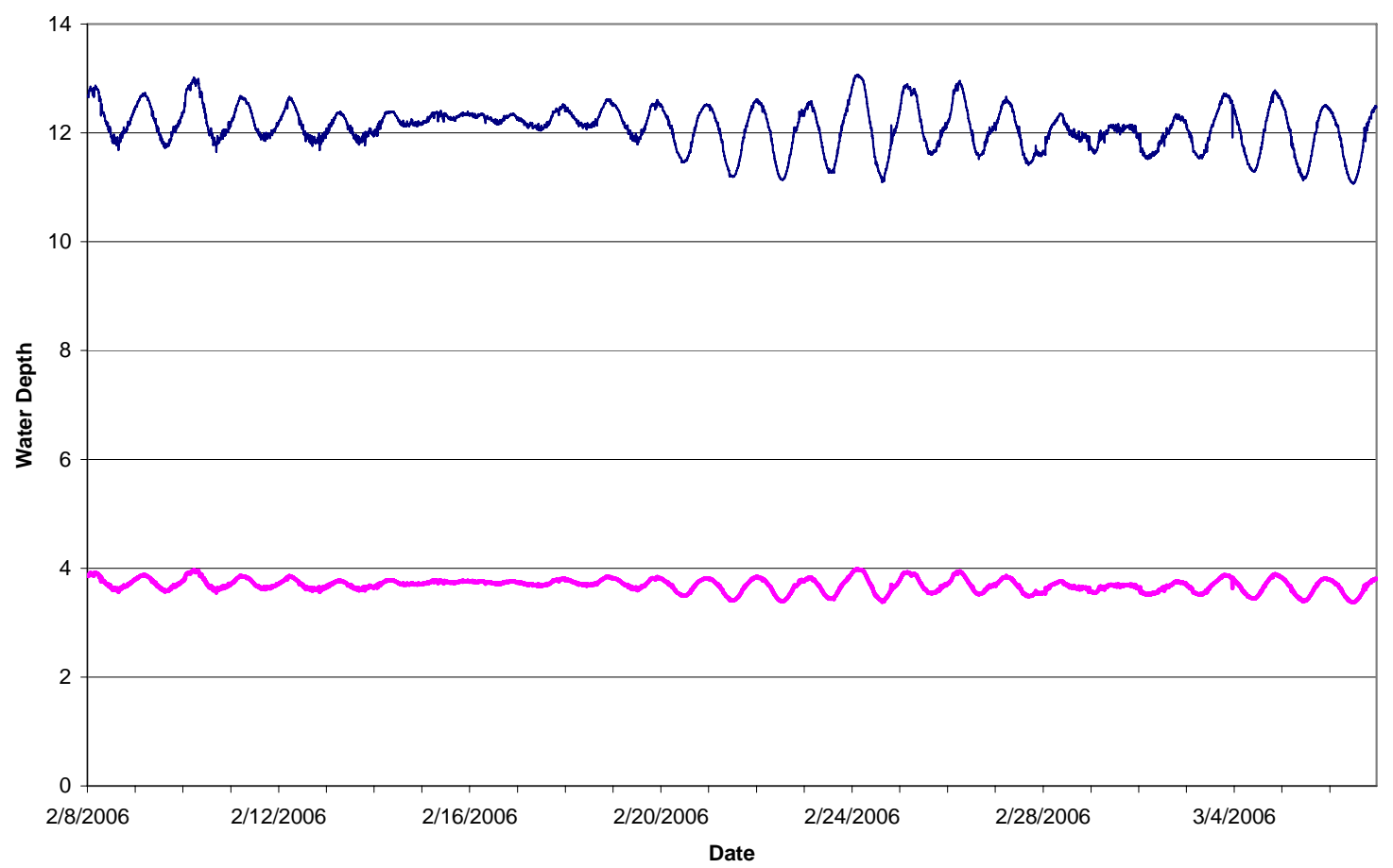

Figure 3-49. Water Depths Recorded at Diversion 


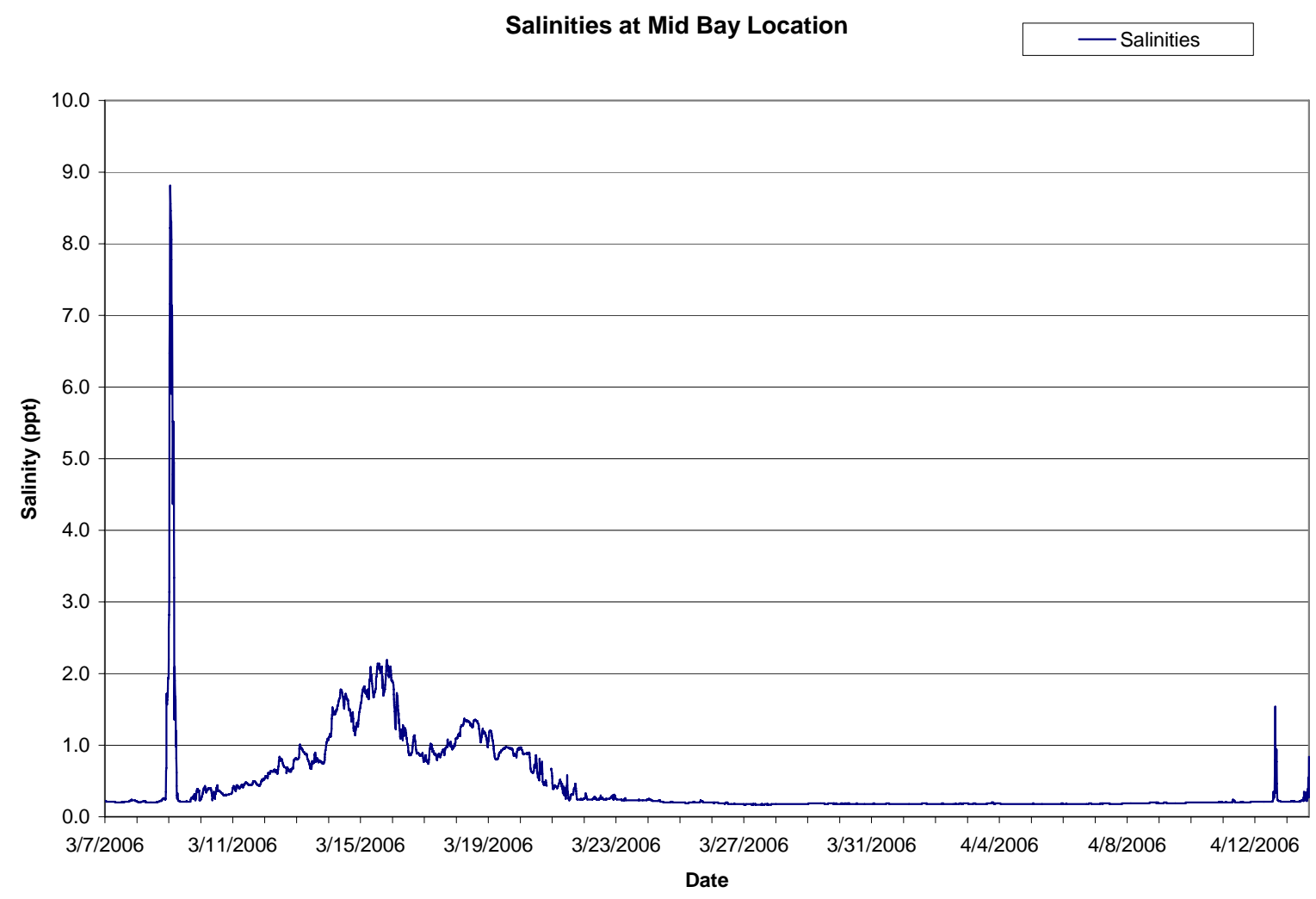

Figure 3-50. Salinities Recorded at Mid Bay

mid-bay location between March $8^{\text {th }}$ and March $23^{\text {rd }}$ with values of up to 2 ppt, while normal baselines values were near the minimum.

\subsection{Wind Measurements}

Wind measurements are recorded at hourly intervals by the National Data Buoy Center (NDBC) at the BURL 1 station located on Southwest Pass approximately 20 miles from the center of the Project area. Raw data were retrieved and analyzed for the years of 2003 through 2006. Average monthly wind speeds were calculated in meters per second for each year and over the entire data set. A summary for each year is presented in Appendix I and Figure 3-51 summarizes the monthly averages for the entire data set. The averages ranged from a low of 8.7 knots $(4.5 \mathrm{~m} / \mathrm{s})$ in August to 15.2 knots $(7.8 \mathrm{~m} / \mathrm{s})$ in December. Figure 3-52 illustrates a composite wind rose for the hourly wind records analyzed. The largest percentage of winds 
recorded blew from the southeast quadrant followed by the northeast. The southwestern quadrant recorded the third highest percentage of winds while the northwestern quadrant recorded the least. Wind roses were also produced for each quarter of during the field study and included in Appendix G. Table 3-3 summarizes these quarterly wind direction statistics. It is important to note that NDBC station was down for significant portions of the $3^{\text {rd }}$ and $4^{\text {th }}$ quarters of 2005 due to Hurricane Katrina.

A smaller subset of the wind data was also analyzed for the time period from March 7, 2006 to April 15, 2006 which coincides with collection of the turbidity and velocity data sets from the mid-bay location. Figure 3-53 summarizes the wind speeds in knots and directions in degrees. During this time period, winds ranged from 0.5 knots to 35 knots ( 0.3 to $18 \mathrm{~m} / \mathrm{s}$ ) with an average of 14 knots $(7.2 \mathrm{~m} / \mathrm{s})$ from $148^{\circ}$.

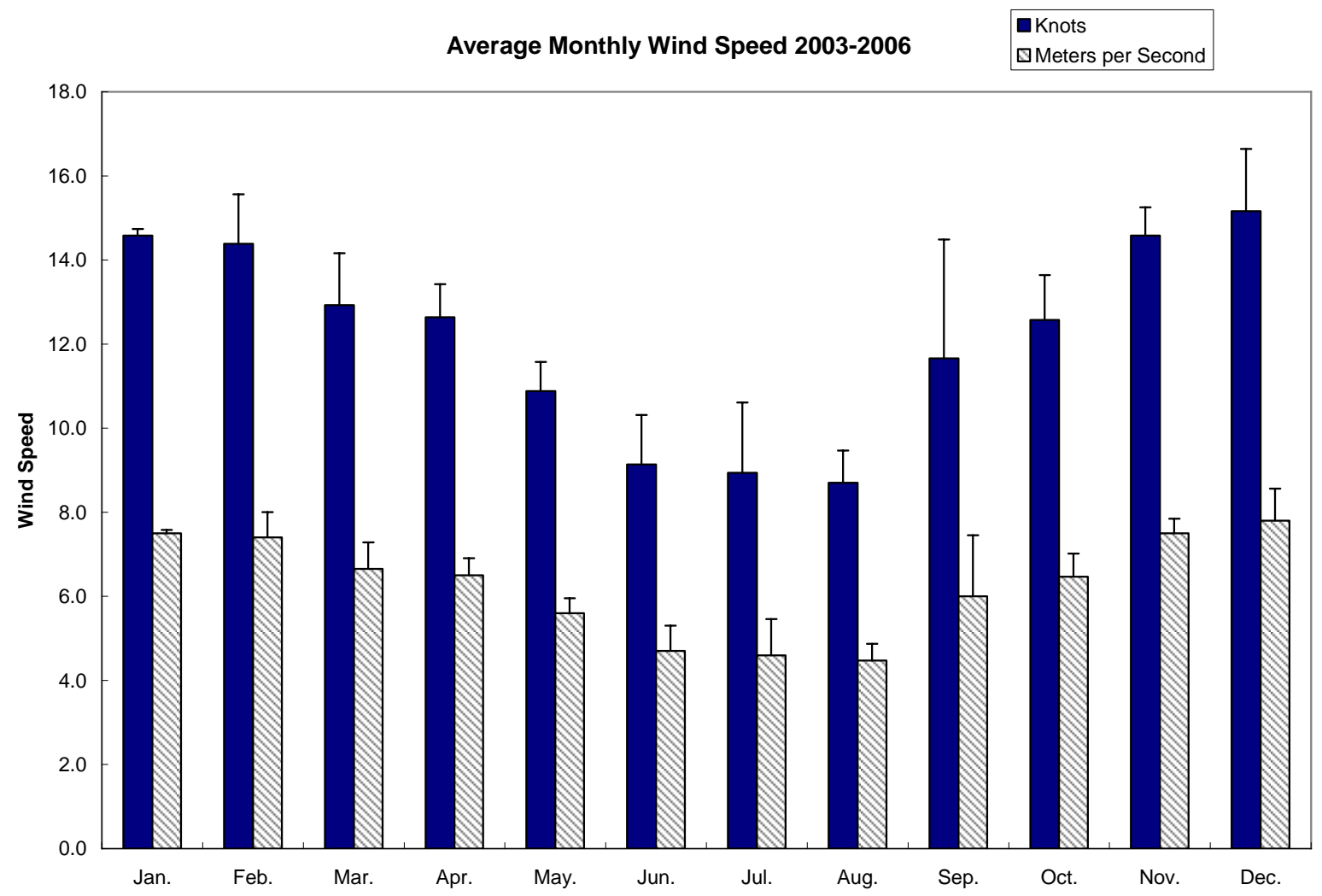

Figure 3-51. Average Monthly Wind Speeds from NDBC Station Burl 1 at Southwest Pass 


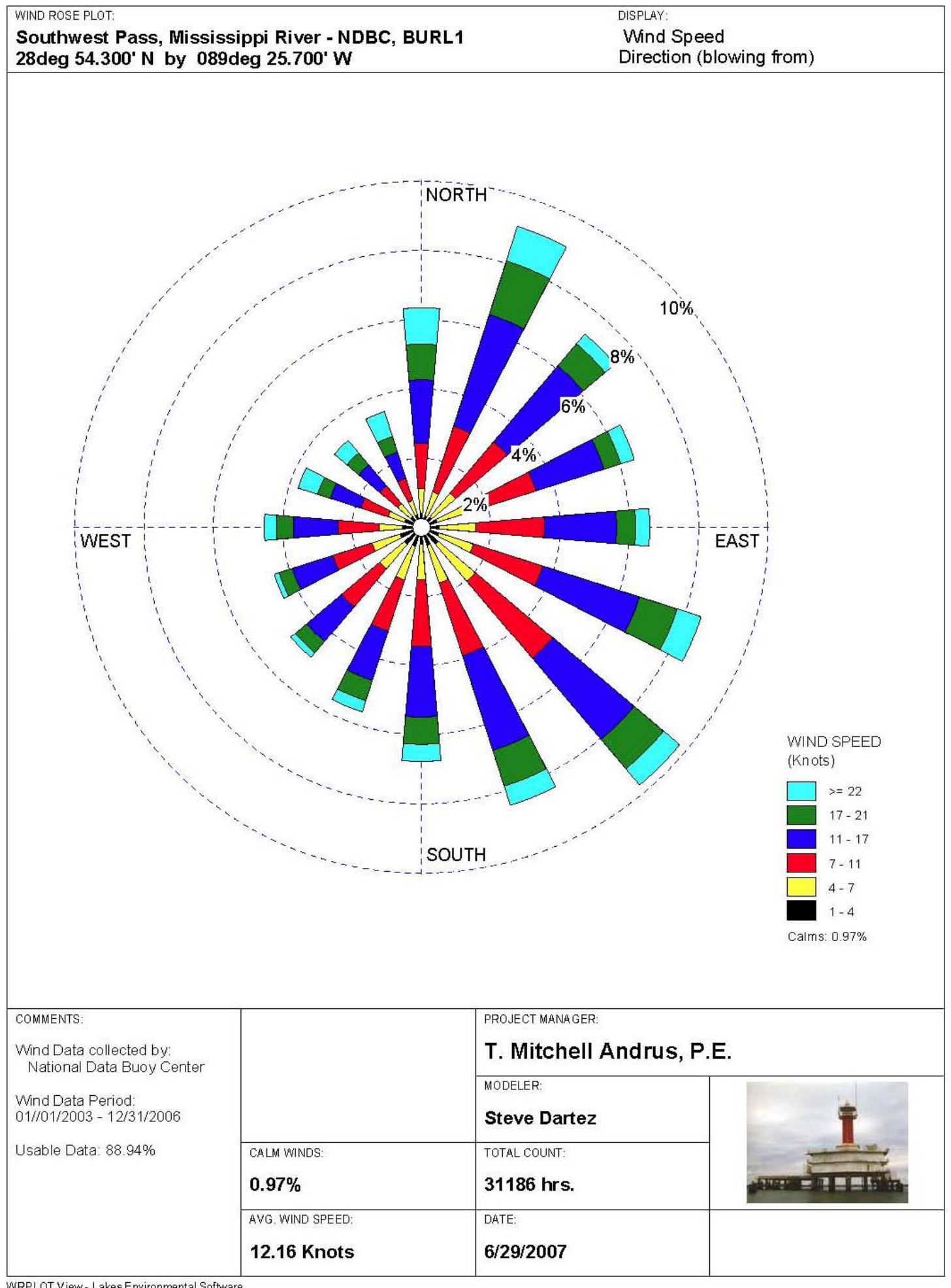

Figure 3-52. Composite Wind Rose Plot from NDBC Station Burl 1 at Southwest Pass 
Table 3-3. Quarterly Wind Direction Percentages - Burl 1 Weather Station at Southwest Pass.

\begin{tabular}{|l|c|c|c|c|}
\hline \multicolumn{5}{|c|}{$\mathbf{2 0 0 4}$} \\
\hline Wind Direction Range & 1st Qtr & 2nd Qtr & 3rd Qtr & 4th Qtr \\
\hline $315^{\circ}-45^{\circ}$ (NW to NE) & 32.1 & 10.3 & 23.4 & 29.8 \\
\hline $45^{\circ}-135^{\circ}$ (NE to SE) & 34.5 & 32.3 & 33.3 & 25.3 \\
\hline $135^{\circ}-225^{\circ}$ (SE to SW) & 21.4 & 45.4 & 19.4 & 30.4 \\
\hline $225^{\circ}-315^{\circ}$ (SW to NW) & 11.5 & 11.0 & 22.2 & 14.4 \\
\hline Calms & 0.4 & 1.0 & 1.6 & 0.2 \\
\hline Missing / Incomplete & 0.3 & 0.5 & 0.2 & 0.2 \\
\hline
\end{tabular}

\begin{tabular}{|l|c|c|c|c|}
\hline \multicolumn{5}{|c|}{ 2005 } \\
\hline Wind Direction Range & 1st Qtr & 2nd Qtr & 3rd Qtr & 4th Qtr \\
\hline $315^{\circ}-45^{\circ}$ (NW to NE) & 29.3 & 16.7 & 17.0 & 16.4 \\
\hline $45^{\circ}-135^{\circ}$ (NE to SE) & 30.1 & 40.8 & 27.0 & 19.7 \\
\hline $135^{\circ}-225^{\circ}$ (SE to SW) & 21.3 & 23.1 & 29.1 & 30.7 \\
\hline $225^{\circ}-315^{\circ}$ (SW to NW) & 19.0 & 18.6 & 24.8 & 28.3 \\
\hline Calms & 0.4 & 0.8 & 1.4 & 0.5 \\
\hline Missing / Incomplete & 0.2 & 0.1 & 35.7 & 89.0 \\
\hline
\end{tabular}

\begin{tabular}{|l|c|c|}
\hline \multicolumn{3}{|c|}{2006} \\
\hline Wind Direction Range & 1st Qtr & 2nd Qtr \\
\hline $315^{\circ}-45^{\circ}$ (NW to NE) & 28.2 & 13.8 \\
\hline $45^{\circ}-135^{\circ}$ (NE to SE) & 34.7 & 21.6 \\
\hline $135^{\circ}-225^{\circ}$ (SE to SW) & 32.8 & 46.5 \\
\hline $225^{\circ}-315^{\circ}$ (SW to NW) & 14.1 & 16.0 \\
\hline Calms & 0.2 & 2.1 \\
\hline Missing / Incomplete & 0.3 & 0.2 \\
\hline
\end{tabular}



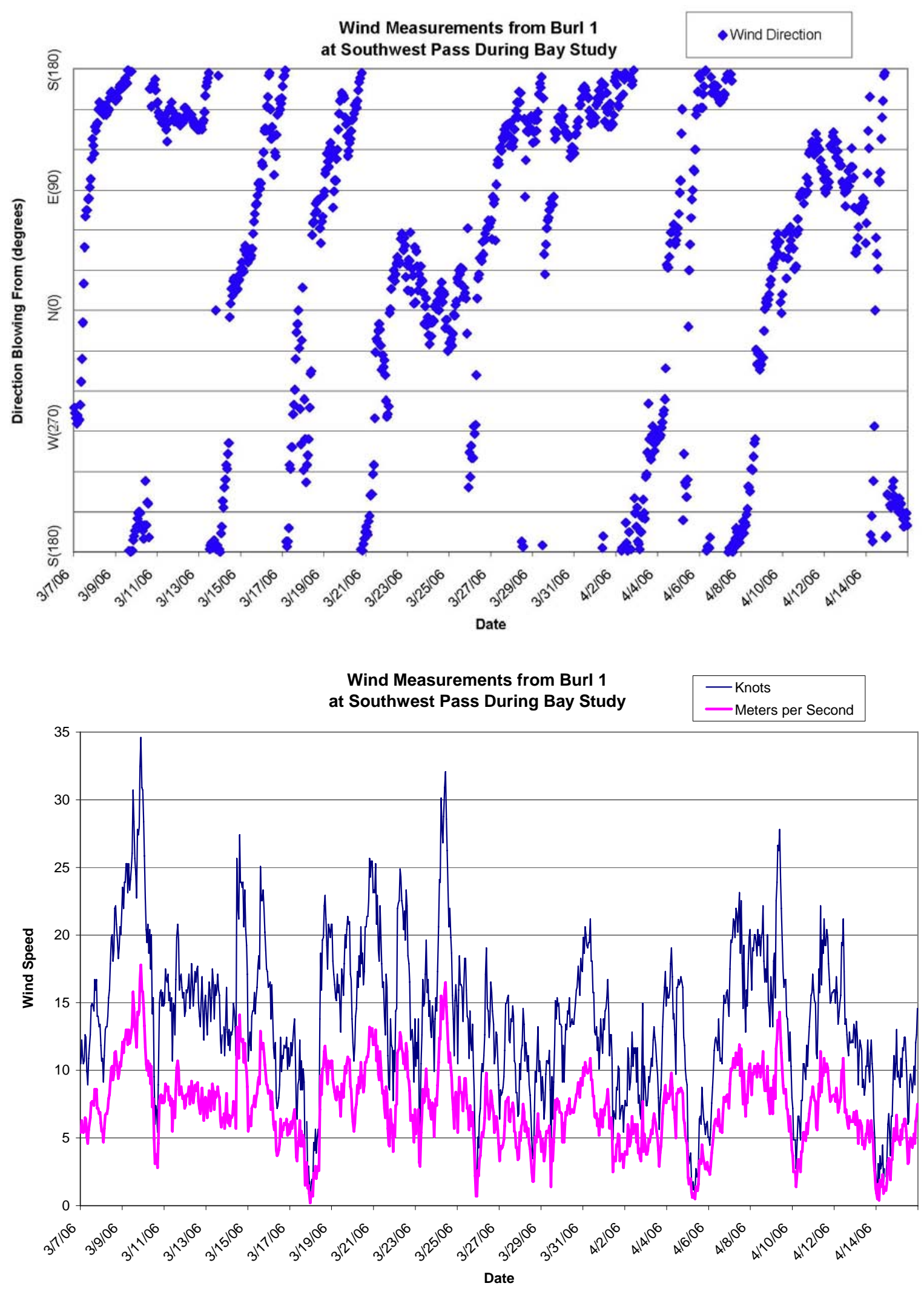

Figure 3-53. Wind Records from NDBC Station Burl 1 at Southwest Pass During Bay Study 


\subsection{Rainfall}

Rainfall data were acquired from the New Orleans International Airport during the study period from January 2004 to April 2006. Although the airport is approximately 80 miles from the study area, it was the closest continual record found for the study period. Figure 3-54 graphs monthly rainfall totals and difference from normal in inches. Average rainfall during the study period was 4.93 in $(12.5 \mathrm{~cm})$ with a maximum of 14.8 in $(37.6 \mathrm{~cm})$ occurring in March 2004 and a minimum of 0.04 in $(0.10 \mathrm{~cm})$ occurring in October 2005. No data were available from August 29 - 31 due to Hurricane Katrina.

Rainfall at New Orleans Intl. Airport - January 2004 to April 2006

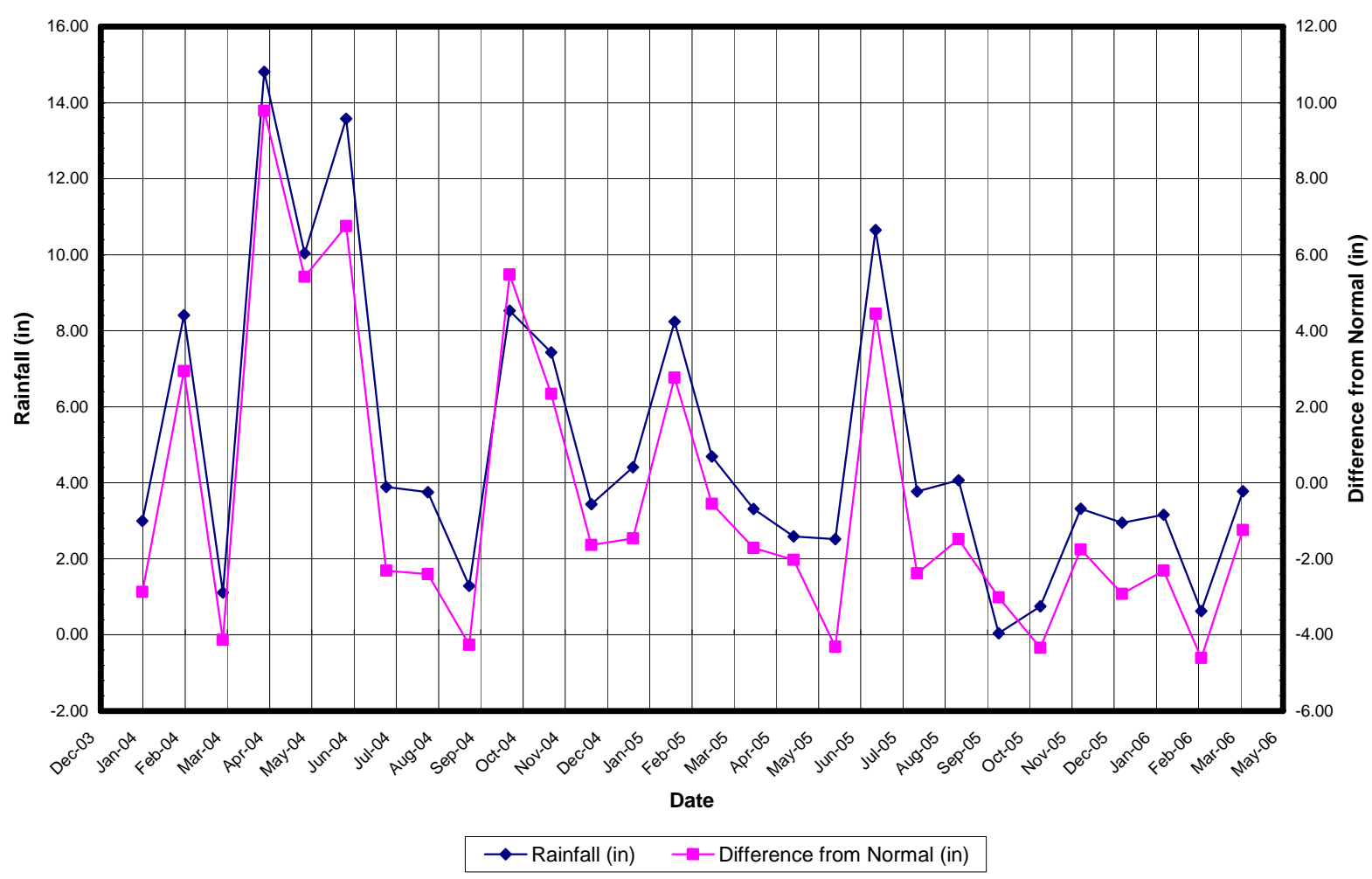

Figure 3-54. Rainfall at New Orleans International Airport During Bay Study 


\subsection{Satellite Imagery Analysis}

While in-situ measurements of various coastal parameters provide localized detail about sediment movement, the use of satellite imagery can give a more regional synopsis of river plume transport both temporally and spatially (Walker, 1996, Walker et al., 2005, Chauhan et al., 2005). Imagery from the Ocean Color Monitor (OCM) of the Oceansat-1 satellite was acquired from the LSU Earth Scan Laboratory (ESL) for use in the West Bay study. The OCM is designed to measure spectral variation of water leaving radiance that can be related to concentration of phytoplankton pigments, suspended sediment, colored dissolved organic matter, and aerosols. The OCM satellite was chosen because of its 360-meter pixel resolution which is critical for the relatively small study area as compared to regional coastal or open ocean studies. OCM collects data in eight spectral channels and has a return interval of every other day (Chauhan et al., 2005). Images were analyzed at the nLw 555 (normalized water leaving radiance) channel which collects data between 545-565 nm. Radiance values were used to assess broad sediment movement patterns within the project boundaries and adjacent areas affected by the diversion.

The ESL OCM archive was searched for usable daytime images over the Mississippi Delta region during the instrument deployment period from 2/8/06 to 4/14/06. Daytime images are taken by the OCM satellite for this region every other day and received and archived by the ESL. Some images were eliminated due to either cloud cover or unexplainably high reflectance values over West Bay which made assessment of sediment patterns unfeasible.

This elimination process yielded 6 useable images listed in Table 3-5 which were analyzed for radiance which is directly related to SPM. The images were processed using a variety of software packages available in the LSU ESL computer lab. Each image was geo-referenced to match the coastlines, registered to a pixel size of 360 meters, enhanced to appropriate reflectance 
ranges, and zoomed into the project area to perform a number of analyses. The final processed images are shown in Figure 3-55. The color schemes represent radiance magnitudes, blue values are the lowest and red values are the highest. Also shown on the images are the instrument deployment locations represented by black dots.

Table 3-4. Summary of Useable OCM Images

\begin{tabular}{|c|c|c|c|c|}
\hline Image & Calendar Date & Julian Date & Time (UTC) & Time (CST) \\
\hline 1 & $2 / 8 / 2006$ & 06039 & $18: 03$ & $12: 03$ PM \\
\hline 2 & $2 / 16 / 2006$ & 06047 & $18: 03$ & $12: 03$ PM \\
\hline 3 & $3 / 2 / 2006$ & 06061 & $18: 03$ & $12: 03$ PM \\
\hline 4 & $3 / 4 / 2006$ & 06063 & $18: 03$ & $12: 03$ PM \\
\hline 5 & $3 / 24 / 2006$ & 06083 & $18: 03$ & $12: 03$ PM \\
\hline 6 & $3 / 26 / 2006$ & 06085 & $18: 03$ & $12: 03$ PM \\
\hline
\end{tabular}

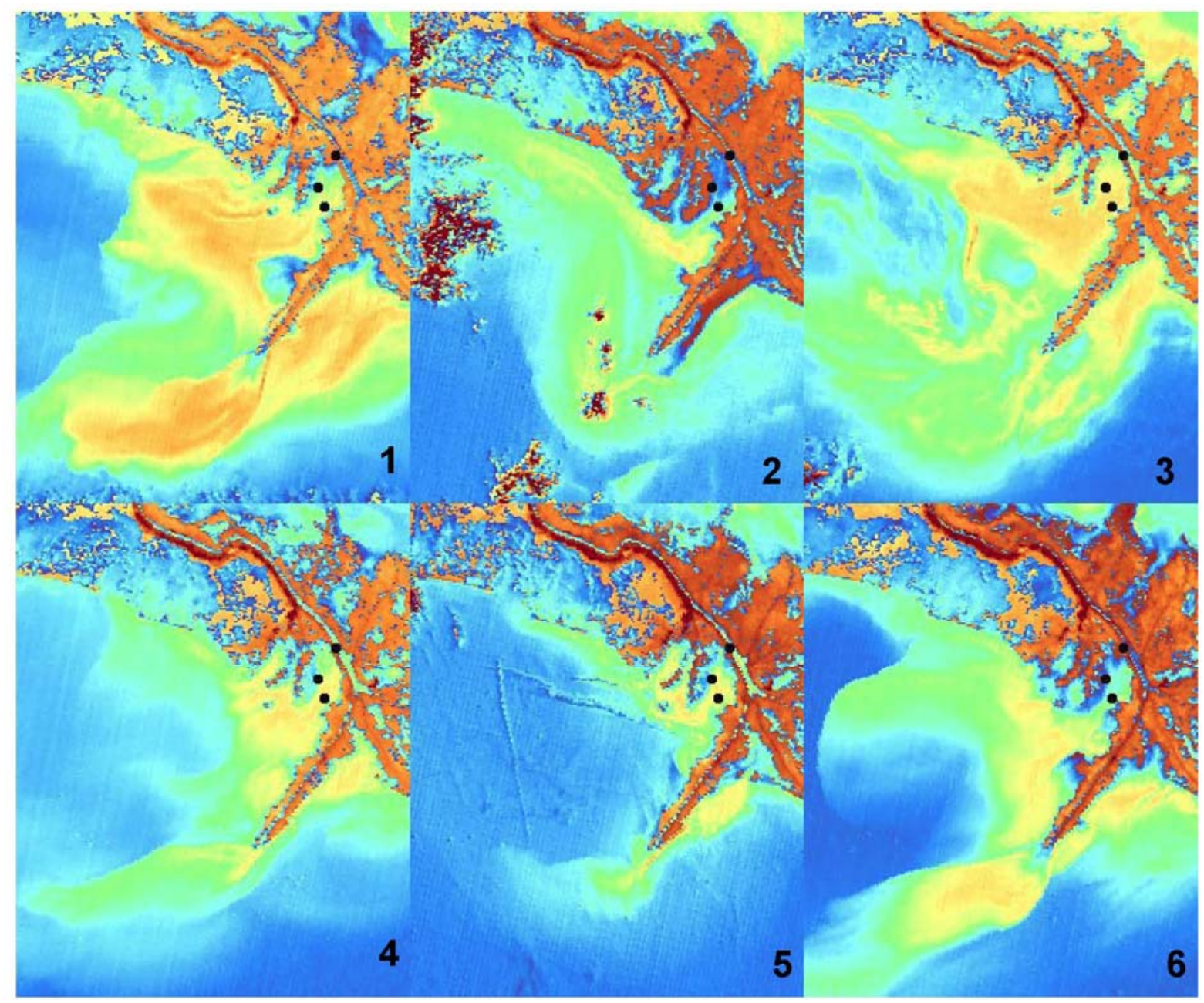

Figure 3-55. Processed OCM Satellite Images 
For more involved studies such as those conducted on the overall Mississippi River plume (Walker, 1996, Walker et al., 2005) and the Ganga-Brahmaputra River plume (Chauhan et al., 2005), suspended sediment concentrations can be calculated using algorithms developed for multiple radiance channels and calibrated with actual water samples. In this study, which only collected data in one channel, general radiance patterns were evaluated by comparing a range of values mapped as contours in Figure 3-56. Radiance values (over non-land portions of the images) ranged from near 0 (clear water) to a maximum of 11.4 in the West Bay study area. The contours mapped are radiance values of 5 and 7. Values above 7 (orange and yellow shades) are considered to be the core of the sediment plumes. The values between 5 and 7 (green shades) are considered to have more diluted sediment concentrations. Values less than 5 (blue shades) are considered to be less turbid waters on the outskirts of the plume. These contours help define the plume size and shape and give some indication of flow directions and intensity.

To assess the amount of the plume that passed through the diversion, the areas encompassed by reflectance contours above 7 were calculated for the portions of the plume north of Southwest Pass for each image. The results of the area calculations are shown in Table 3-5. The areas range from 13.5 to $152 \mathrm{mi}^{2}$ (35 to $394 \mathrm{~km}^{2}$ ) demonstrating a wide range of variability which could possibly be attributed to changes in wind patterns, river flow, and sediment concentrations.

Table 3-5. Area of Sediment Plume Passing Through Diversion (nLw $555>7$ )

\begin{tabular}{|c|c|c|c|}
\hline \multicolumn{4}{|c|}{ West Bay Sediment Plume Size } \\
\hline Image & Area (acres) & Area $\left(\mathbf{k m}^{\mathbf{2}} \mathbf{)}\right.$ & Area $\mathbf{( m i}^{\mathbf{2}} \mathbf{)}$ \\
\hline 1 & 97,359 & 394 & 152 \\
\hline 2 & 8,649 & 35 & 14 \\
\hline 3 & 75,367 & 305 & 117 \\
\hline 4 & 31,629 & 128 & 49 \\
\hline 5 & 8,896 & 36 & 14 \\
\hline 6 & 36,324 & 147 & 57 \\
\hline
\end{tabular}




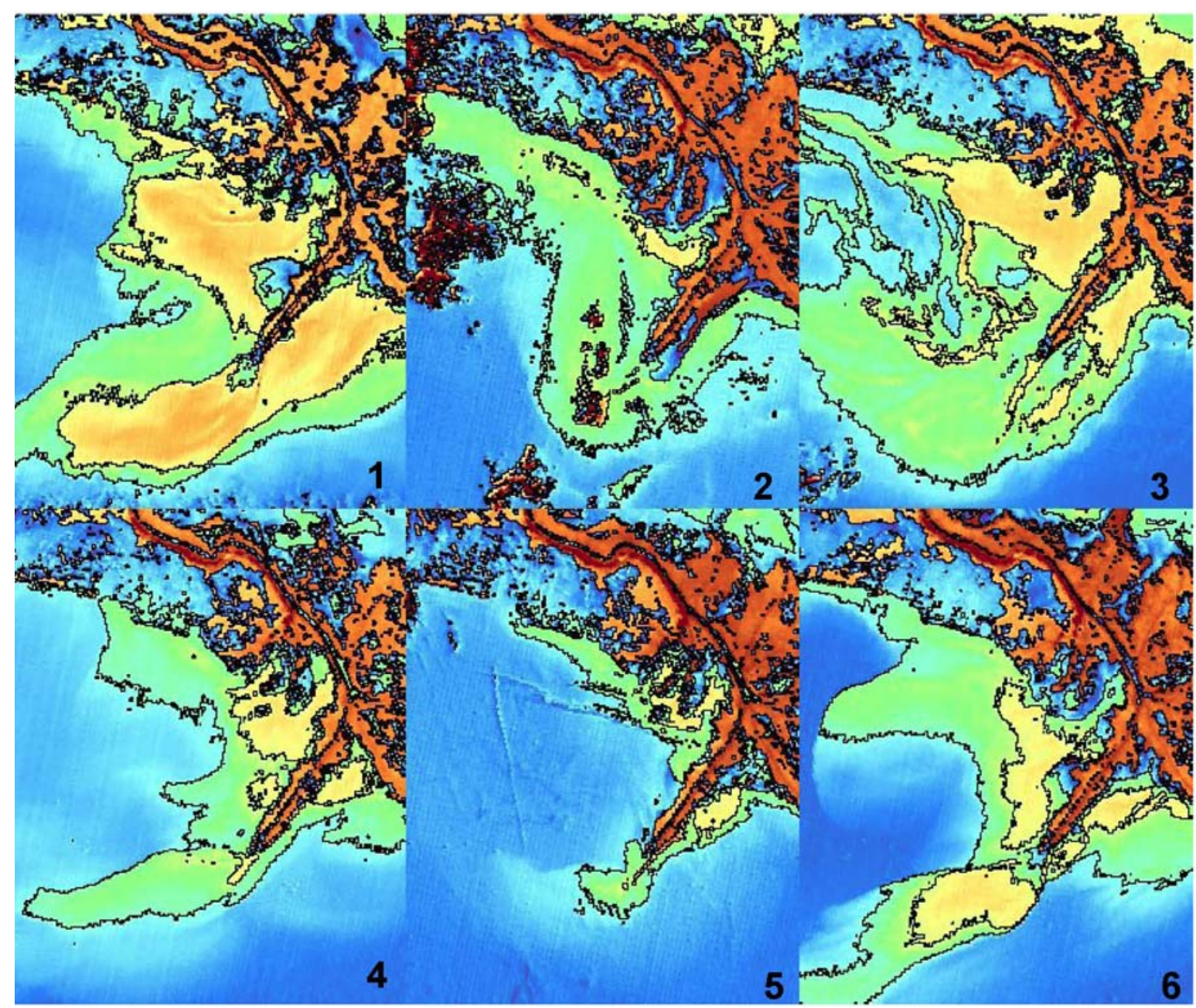

Figure 3-56. Radiance Contour Mapping

Further statistical evaluations were performed on the plume for the West Bay project area (near diversion - in the project area) and a portion of the plume as it entered the Gulf of Mexico (away from diversion - after exiting the project area). Figure 3-57 depicts two polygons (near and away) that were digitized for each image.

Statistical analyses on near and away polygons produced minimum, maximum, and mean reflectance values along with standard deviations. The results shown below in Table 3-6 show that the mean radiance for the near-diversion polygon is either below or very close in value to the away polygon. This would indicate that much of the sediment is remaining in suspension and exiting the project area into the Gulf. 


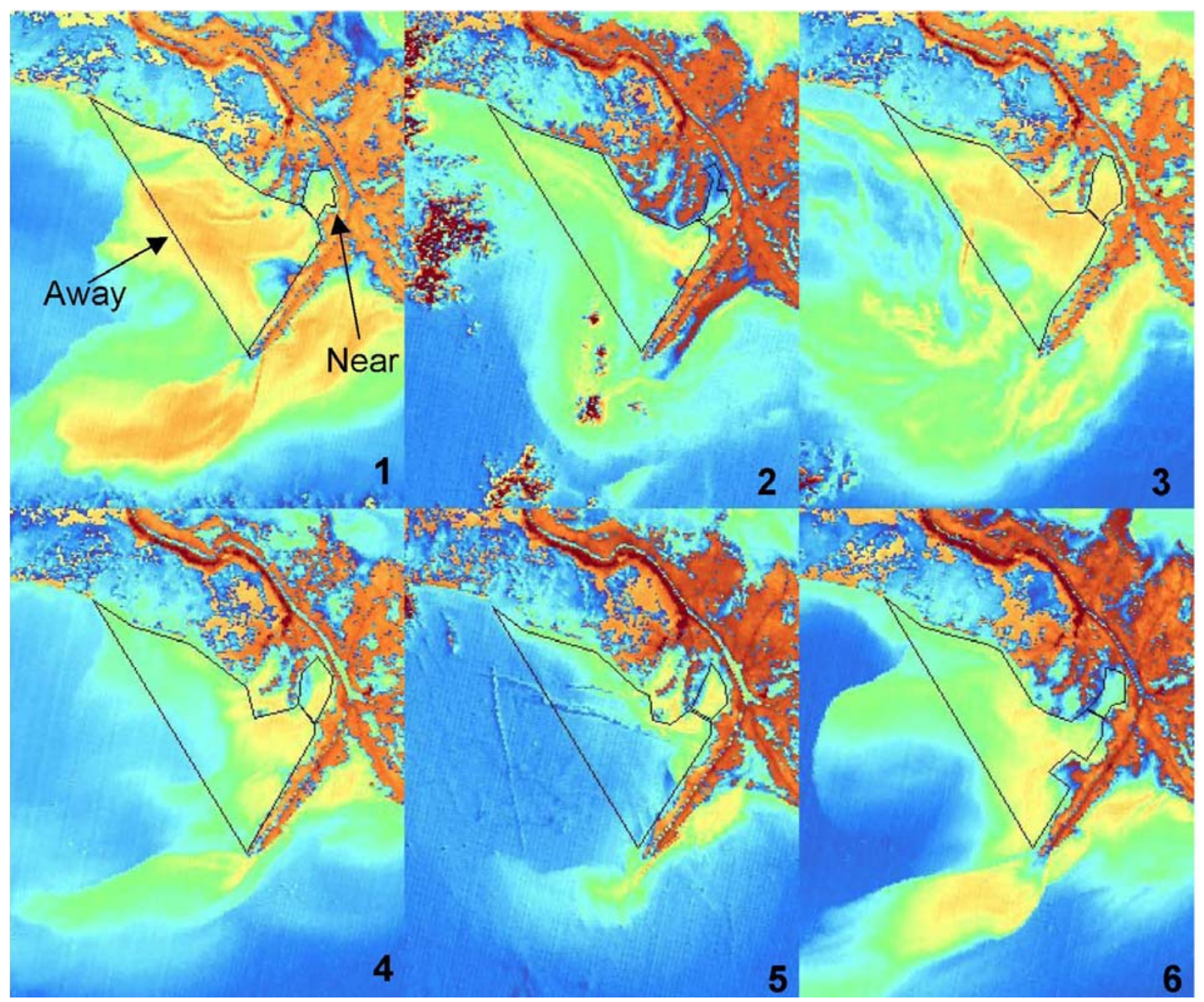

Figure 3-57. Radiance Analysis Areas

Table 3-6. Reflectance Polygon Statistics

\begin{tabular}{|c|c|c|c|c|c|}
\hline \multicolumn{6}{|c|}{ West Bay Sediment Plume Size } \\
\hline \multirow{2}{*}{ Image } & Polygon & $\begin{array}{c}\text { Mean } \\
\text { Radiance }\end{array}$ & $\begin{array}{c}\text { Min } \\
\text { Radiance }\end{array}$ & $\begin{array}{c}\text { Max } \\
\text { Radiance }\end{array}$ & $\begin{array}{c}\text { Standard } \\
\text { Deviation }\end{array}$ \\
\hline \multirow{2}{*}{1} & Near & 6.4 & 1.8 & 8.0 & 1.0 \\
\cline { 2 - 6 } & Away & 7.3 & 0.2 & 10.6 & 1.3 \\
\hline \multirow{2}{*}{2} & Near & 3.7 & 0.7 & 6.8 & 1.5 \\
\cline { 2 - 6 } & Away & 6.2 & 0.1 & 11.4 & 0.9 \\
\hline \multirow{2}{*}{3} & Near & 7.6 & 4.3 & 8.8 & 0.7 \\
\cline { 2 - 6 } & Away & 7.1 & 0.2 & 10.5 & 1.1 \\
\hline \multirow{2}{*}{4} & Near & 6.4 & 0.6 & 10.6 & 1.4 \\
\cline { 2 - 6 } & Away & 6.1 & 0.1 & 9.6 & 1.0 \\
\hline \multirow{2}{*}{5} & Near & 6.4 & 0.9 & 8.2 & 1.4 \\
\cline { 2 - 6 } & Away & 4.4 & 0.3 & 8.1 & 1.3 \\
\hline \multirow{2}{*}{6} & Near & 4.8 & 0.8 & 6.9 & 1.3 \\
\cline { 2 - 6 } & Away & 6.6 & 1.2 & 8.1 & 0.8 \\
\hline
\end{tabular}




\section{DISCUSSION}

\subsection{Sediment Flux}

The average annual water and sediment discharges of the Mississippi River were estimated by Milliman and Meade (1983) to be $470 \times 10^{6}$ ac-ft and $2.3 \times 10^{8}$ tons $/ \mathrm{yr}\left(580 \mathrm{~km}^{3}\right.$ and $2.1 \mathrm{x}$ $10^{11} \mathrm{~kg} / \mathrm{yr}$ ), respectively. Mississippi River sediment loads have decreased by as much as $70 \%$ since 1850 partly due to reservoir and dam construction on major upstream tributaries (Kesel, 1988). Combined with levee construction, this decline in sediment loads has contributed to accelerated land loss in the Louisiana coastal zone (Kesel, 1988).

Characterization of sediment flux patterns through the West Bay diversion is essential in evaluating diversion performance. The detailed profiles of flow and sediment distribution in the water column described at high and low water will provide boundary conditions for sediment flux estimates. Therefore, characterization of the behavior of suspended sediment loads as a function of river flow is critical.

In general, suspended sediment concentrations (SSC) increase with increasing river discharge (Fig. 3-32). Coarse sediments tend to compose higher percentages of SSC during winter and spring hydrograph maximums (Fig. 3-33). Coarse SSC also display less variability in relation to river discharge than fine sediments (Figs. 3-34 and 3-35) (Mossa, 1996; CH2M Hill et al., 2004). Silt-clay concentrations are more sensitive to sediment supply coming from catchment runoff which is a primary reason for variability in relation to flow. Initial floods occurring during the first major hydrograph rise at the beginning of each water year deliver easily erodible fine sediments from runoff and bank failures contributing to SSC peaks preceding discharge crests. Similar discharge values on falling limb of the hydrograph tend to produce lower SSC values because significant portions the initially eroded sediments are no longer 
present (referred to as hysteresis). In contrast, sand supply on the river bed remains abundant and maintains greater correlation with river discharge regardless of rising or falling hydrograph limbs. Leads in SSC peaks, or phase lags, increase with discharge maxima, with lead times of up to 85 days (Mossa, 1996). Generally, phase lags and hysteresis effects tend to diminish as flows propagate downstream causing SSC peaks and discharge crests to coincide (Mossa, 1996). Hence, for the purposes of this study, SSC is considered to be directly proportional to river / diversion discharge.

Also decreasing in the downstream direction is bed material grain size traveling along the river channel bottom (Fisk, 1951). In the final, low-gradient river section, bedload grain size evolves downstream from fine sand-dominated near Old River to silt-dominated at Head of Passes (Keown et al. 1981, 1986) while the disaggregated suspended load consists of about 65\% clay and 35\% silt, with some sand at higher discharge periods (Coleman, 1988). Observed sand percentages throughout the water year at Tarbert Landing from 1983 to 1998 ranged from 0 to 62\% with a median of 6\% (CH2M Hill et al., 2004). Maximum sand percentages generally occur between January and May and make up approximately 25\% of the SSC at higher flows (Figs. 3-32 and 3-33).

A number of flow and sediment data sets were discussed in Sections 3.3 and 3.4. A comparison of diversion flow measurements from the USACE long term monthly data set to the short term more detailed LSU-CSI diversion flow study revealed flow differences of less than 10\%. Therefore, the long term USACE flow data set can be used with reasonable confidence. Table 4-1 shows maximum, minimum, and average total suspended sediment concentrations (SSC) at Tarbert Landing, Belle Chase and West Bay. 
Table 4 - 1. Mississippi River Total Suspended Sediment Concentrations

\begin{tabular}{|l|c|c|c|}
\hline \multicolumn{5}{|c|}{ Sediment Concentrations (mg/l) } \\
\hline \multicolumn{1}{|c|}{ Location } & Maximum & Minimum & Average \\
\hline Tarbert Landing & 992 & 57 & 259 \\
\hline Bell Chase & 746 & 3 & 213 \\
\hline West Bay* & 155 & 53 & 82 \\
\hline
\end{tabular}

$*$ Values estimated from calibrated turbidity data.

Observations by Tulane University of the Lower Mississippi River channel at a low river discharge rate of 280,000 $\mathrm{ft}^{3} / \mathrm{s}\left(7,930 \mathrm{~m}^{3} / \mathrm{s}\right)$ measured at Tarbert Landing in November 2001 revealed SSC of 130-150 mg/l in the upper layers of outgoing river water near Venice (Galler and Allison, 2007). Calibrated satellite images by Walker (1996) observed SSC of approximately $400 \mathrm{mg} / \mathrm{l}$ at a high river discharge rate of 1,000,000 $\mathrm{ft}^{3} / \mathrm{s}\left(28,300 \mathrm{~m}^{3} / \mathrm{s}\right)$ measured at Tarbert Landing in April 1989. Similar SSC were seen in the Belle Chase data set presented in Figure 3-37. These flow ranges are just above and below maximum and minimum average river discharges at Tarbert Landing (Fig. 3-29).

To determine sediment loads, the average monthly flows in Figure 3-26 were converted to volumes of water passing through the diversion in liters. Then, total sediment flux was calculated for a range of sediment concentrations. The volumes were then multiplied by the average SSC of various data sets and converted to tons. Figure 4-1 illustrates estimated monthly sediment loads over the three year study period using the Belle Chase average of $213 \mathrm{mg} / \mathrm{L}$. By summing all of the monthly sediment loads it is estimated that a total $8.5 \times 10^{6}$ tons $\left(7.7 \times 10^{9}\right.$ kg) of sediment entered West Bay through the sediment diversion from December 2003 to November 2006 with an average of $2.9 \times 10^{6}$ tons $\left(2.6 \times 10^{9} \mathrm{~kg}\right)$ of sediment per year. It is also speculated that a significant amount of coarse material passed through the diversion during the Winter 2004/2005 peak river and diversion discharge. The estimated sediment flux through the diversion during this peak is approximately $0.70 \times 10^{6}$ tons $\left(0.64 \times 10^{9} \mathrm{~kg}\right)$ as shown in Figure 4- 
1. If $25 \%$ of this sediment flux were coarse, approximately $0.18 \times 10^{6}$ tons $\left(0.16 \times 10^{9} \mathrm{~kg}\right)$ of sand passed through the diversion during this peak. The estimate of total sediment flux increases by $88 \%$ to $1.3 \times 10^{6}$ tons $\left(1.2 \times 10^{9} \mathrm{~kg}\right.$ ) when a SSC of $400 \mathrm{mg} / \mathrm{l}$ (from Walker, 1996) is used in the calculation. Conversely, the estimate of total sediment flux decreases by approximately 35\% to $0.25 \times 10^{6}$ tons $\left(0.23 \times 10^{9} \mathrm{~kg}\right)$ when a SSC of $140 \mathrm{mg} / \mathrm{l}$ (from Galler and Allison, 2007) is used at lower diversion flows. Minimum, maximum and average sediment flux rates estimated during the diversion study are listed in Table 4-2.

As demonstrated by Mossa (1996) and Snedden et al. (2006), SSC loading varies with time depending on river discharge, location upstream or downstream within the river, and seasonal rising and falling of the river hydrograph. Therefore, the sediment fluxes presented in Table 4-2 may be underestimates during rising river stage conditions and over estimates during falling river stage conditions.

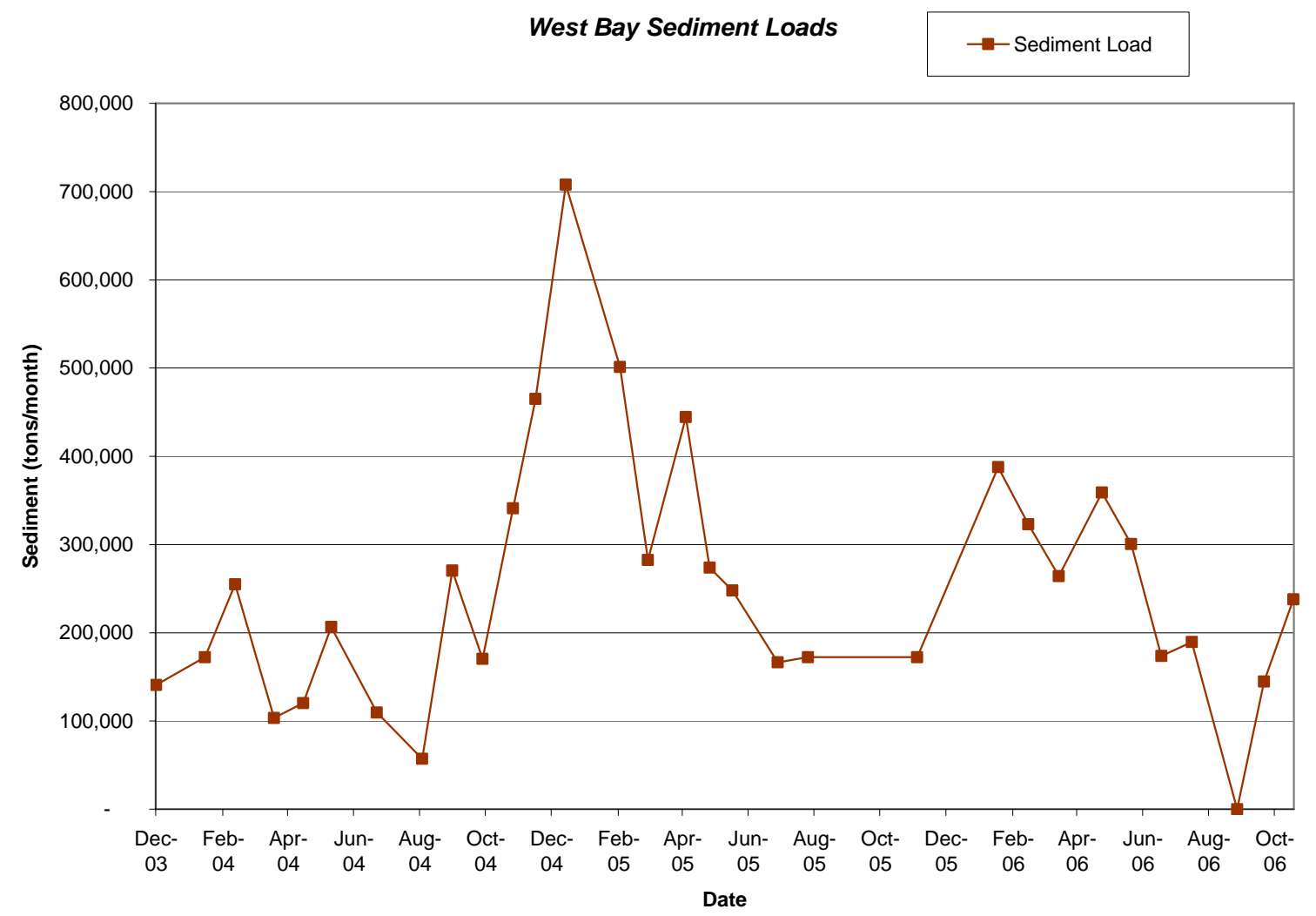

Figure 4-1. Estimated Sediment Loads Passing Through the Diversion 
Table 4 - 2. Sediment Flux Estimations Based on Observed Diversion Flows

\begin{tabular}{|l|c|c|c|c|c|}
\hline \multicolumn{1}{|c|}{ Range } & Date of Occurrence & $\begin{array}{c}\text { Diversion } \\
\text { Flow } \\
\left(\mathrm{ft}^{3} / \mathrm{s}\right)\end{array}$ & $\begin{array}{c}\text { Diversion } \\
\text { Flow } \\
\left(\mathrm{m}^{3} / \mathrm{s}\right)\end{array}$ & $\begin{array}{c}\text { Monthly } \\
\text { Sediment Flux } \\
(\text { tons } / \mathrm{mo})\end{array}$ & $\begin{array}{c}\text { Daily } \\
\text { Sediment Flux } \\
\text { (tons/day) }\end{array}$ \\
\hline Maximum & Feb 2005 & 41,100 & 1,160 & $1.33 \times 10^{6}$ & 44,300 \\
\hline Average & Jan 2004 - Nov 2006 & 13,800 & 390 & $0.24 \times 10^{6}$ & 8,050 \\
\hline Minimum & Sep 2004* & 3,310 & 94 & $0.04 \times 10^{6}$ & 1,250 \\
\hline
\end{tabular}

*Date of lowest observed positive flow (river to bay). A negative flow (bay to river) was observed in September 2006.

\section{2 $\quad{ }^{7}$ Be Sedimentation Analysis}

Sediment accumulation rates (SAR's) were calculated by dividing the ${ }^{7}$ Be decay constant by the slope of the best fit regression line of the natural log of the ${ }^{7}$ Be activity vs. depth at each sample location (equation 4 in Section 2.1.4). $\mathrm{R}^{2}$ values were also determined to indicate “goodness of fit”. Table 4-3 summarizes the results of these calculations.

SAR's calculated over the study period range from 0 to $2.5 \mathrm{~cm} / \mathrm{mo}$ (0 to $1.0 \mathrm{in} / \mathrm{mo}$ ) and average $0.6 \mathrm{~cm} / \mathrm{mo}(0.2 \mathrm{in} / \mathrm{mo})$ for sites that were sampled at each collection event. While these SAR's are valuable indicators for depositional comparisons within the data set, this data set is insufficient to produce a closely constrained sediment budget, primarily due to influences of hurricane-related resuspension, and variability of the river hydrograph and sediment supply, with respect to the timing of sample collection.

A more appropriate analysis is the comparison of the ratio of measured ${ }^{7}$ Be inventories to theoretical inventories derived from local atmospheric ${ }^{7}$ Be deposition rates (Booth et al., 2000). Locations with ${ }^{7} \mathrm{Be}$ inventory ratios $>1$ are interpreted as depositional and those $<1$ are considered as erosional/non-depositional. The portion of the ${ }^{7}$ Be sediment inventory that can be attributed to atmospheric deposition was measured at $3.10 \mathrm{dpm} / \mathrm{cm}^{2}$ by Baskaran et al. (1993) at Galveston, Texas. ${ }^{7}$ Be flux ratios were calculated by dividing the inventories from Table 3-1 by the atmospheric inventory and listed in Table 4-4. 
Table 4 - 3. Sediment Accumulation Rates (cm/mo)

\begin{tabular}{|c|c|c|c|c|c|c|}
\hline Site ID & Spring 04 & Fall 04 & Fall 05 & Spring 06 & Average & Category \\
\hline WB01* & 1.45 & 0.00 & $\mathrm{NF}^{\star \star \star \star}$ & 0.00 & 0.48 & Center \\
\hline WB02 & $N S^{* *}$ & $\mathrm{NS}^{* \star}$ & 0.17 & 2.43 & 1.30 & Center \\
\hline WB03* & 0.77 & 0.00 & 1.97 & 0.00 & 0.69 & Periphery \\
\hline WBO4* & 0.61 & 0.00 & 0.00 & 0.00 & 0.15 & Periphery \\
\hline WB05* & 0.46 & 0.00 & $\mathrm{NF}^{\star \star \star \star}$ & 0.00 & 0.15 & Periphery \\
\hline WB06* & 0.00 & 0.00 & $\mathrm{NF}^{\star \star \star \star}$ & 0.00 & 0.00 & Periphery \\
\hline WB07* & 0.00 & 0.94 & 0.00 & 1.07 & 0.50 & Center \\
\hline WB08 & NS** & $\mathrm{NS}^{* \star}$ & $\mathrm{NF}^{* \star \star *}$ & 0.00 & 0.00 & Center \\
\hline WB09 & $N S^{* *}$ & $\mathrm{NS}^{\star *}$ & $\mathrm{NF}^{\star \star \star \star}$ & 0.00 & 0.00 & Center \\
\hline WB10* & 0.00 & 2.50 & 1.00 & 2.00 & 1.25 & Center \\
\hline WB11 & 1.01 & 0.00 & NS & $N S^{* \star}$ & 0.50 & Periphery \\
\hline WB12* & $N F^{\star \star \star *}$ & $\mathrm{NF}^{\star \star \star \star}$ & 0.00 & 0.00 & 0.00 & Periphery \\
\hline WB13 & 0.00 & 0.00 & $N S^{* \star}$ & NS & 0.00 & Periphery \\
\hline WB14 & $\mathrm{NF}^{\star \star \star \star}$ & $\mathrm{NS}^{* \star}$ & $N S^{\star \star}$ & NS & 0.00 & Periphery \\
\hline WB15* & $N F^{\star \star \star *}$ & 0.00 & 0.00 & 0.00 & 0.00 & Periphery \\
\hline WB17 & 0.00 & 0.00 & $N S^{\star \star}$ & $\mathrm{NF}^{\star \star \star *}$ & 0.00 & Periphery \\
\hline WB18 & 0.00 & 0.00 & $N S^{* \star}$ & $N S^{* *}$ & 0.00 & North \\
\hline WB19 & 0.73 & 0.00 & $N S^{* \star}$ & $\mathrm{NS}^{* *}$ & 0.36 & North \\
\hline WB21 & 2.07 & 2.19 & $N S^{\star *}$ & $N S^{\star \star}$ & 2.13 & North \\
\hline WB22 & 0.54 & 0.56 & $N S^{\star \star}$ & $N S^{\star \star}$ & 0.55 & Center \\
\hline Average & 0.59 & 0.41 & 0.31 & 0.32 & 0.41 & \\
\hline $\begin{array}{c}\text { Average for } \\
\text { Common Sites }\end{array}$ & 0.55 & 0.43 & 0.33 & 0.13 & 0.36 & \\
\hline
\end{tabular}

*Sites were sampled at each collection event.

${ }^{* *} \mathrm{NS}=$ Not sampled

${ }^{* *} \mathrm{NF}=$ Not fit for $\mathrm{R}^{2}<1$.

${ }^{7}$ Be inventory ratios calculated over the study period range from 0 to 9.25 and averaged 0.87 for sites that were sampled at each collection event. Approximately $10 \%$ of the cores sampled are interpreted as experiencing net sediment accumulation (flux ratios $>1$ ). Approximately $60 \%$ of the samples are interpreted as receiving some sediment (i.e., ${ }^{7} \mathrm{Be}$ is detectable) but experiencing net erosion or non-deposition (flux ratios between 0 and 1). Approximately $30 \%$ of the cores sampled are interpreted as experiencing only erosion and no sediment input (flux ratios $=0$ ).

Although atmospheric ${ }^{7} \mathrm{Be}$ flux rates are relatively constant with latitude (Baskaran et. al, 1997), variations can be attributed to rainfall, seasonality, and water column mixing. Although 
Table 4 - 4. ${ }^{7}$ Be Flux Ratios

\begin{tabular}{|c|c|c|c|c|c|}
\hline Site ID & Spring 04 & Fall 04 & Fall 05 & Spring 06 & Category \\
\hline WB01* & 0.79 & 0.00 & 0.79 & 0.00 & Center \\
\hline WB02 & $\mathrm{NS}^{* *}$ & $\mathrm{NS}^{* *}$ & 0.16 & 0.11 & Center \\
\hline WB03* & 1.95 & 0.00 & 0.53 & 0.11 & Periphery \\
\hline WB04* & 0.64 & 0.00 & 0.25 & 0.00 & Periphery \\
\hline WB05* & 0.82 & 1.02 & 9.25 & 0.31 & Periphery \\
\hline WB06* & 0.28 & 0.00 & 8.55 & 0.08 & Periphery \\
\hline WB07* & 0.17 & 0.36 & 0.11 & 0.26 & Center \\
\hline WB08 & $N S^{\star \star}$ & $N S^{\star \star}$ & 0.43 & 0.00 & Center \\
\hline WB09 & $N S^{* *}$ & $\mathrm{NS}^{\star *}$ & 0.34 & 0.00 & Center \\
\hline WB10* & 0.00 & 0.56 & 0.11 & 1.06 & Center \\
\hline WB11 & 0.68 & 0.06 & NS & NS & Periphery \\
\hline WB12* & 0.96 & 0.45 & 0.64 & 0.56 & Periphery \\
\hline WB13 & 0.00 & 0.00 & $\mathrm{NS}^{* *}$ & $\mathrm{NS}^{* *}$ & Periphery \\
\hline WB14 & 0.37 & $\mathrm{NS}^{* *}$ & $\mathrm{NS}^{* *}$ & $\mathrm{NS}^{* *}$ & Periphery \\
\hline WB15* & 0.44 & 0.16 & 0.15 & 0.00 & Periphery \\
\hline WB17 & 0.00 & 0.00 & NS & 0.32 & Periphery \\
\hline WB18 & 0.00 & 0.00 & $\mathrm{NS}^{* \star}$ & $N S^{* *}$ & North \\
\hline WB19 & 0.47 & 0.00 & $\mathrm{NS}^{\star \star}$ & $N S^{* \star}$ & North \\
\hline WB21 & 0.62 & 0.11 & $\mathrm{NS}^{\star *}$ & $\mathrm{NS}^{* *}$ & North \\
\hline WB22 & 0.25 & 0.73 & $N S^{* *}$ & $N S^{* \star}$ & Center \\
\hline
\end{tabular}

*Sites were sampled at each collection event.

**NS = Not sampled

${ }^{7}$ Be generally has a short residence time in the water column of approximately 1 to 20 days (Baskaran et al. 1997), disturbances from caused by physical mixing can prolong the residence time of particle-bound ${ }^{7} \mathrm{Be}$ in the water column by as much as 50 days (Collis, 2006). Atmospheric ${ }^{7}$ Be concentrations have been also been found to vary temporally by season (Olsen et al., 1986; Baskaran et al., 1993; Rehfeld and Heimann, 1995). Decreased atmospheric transport of ${ }^{7}$ Be downward in the Fall could lead to a decrease in ${ }^{7}$ Be delivery to the Earth's surface (Dibb and Meeker, 1994; Baskaran, 1995).

Studies have also shown a direct correlation between ${ }^{7}$ Be fluxes from the atmosphere and precipitation events (Olsen et al., 1986; Vogler et al., 1996). Rainfall amounts just prior to the Fall 2004, Fall 2005, and Spring 2006 sampling events ranged from 1 to 4 inches $(2.5$ to $10 \mathrm{~cm})$ 
while the rainfall amount in the month prior to the Spring 2004 sampling event exceeded 14 inches $(35 \mathrm{~cm})$ (Fig. 3-54). This could have contributed to the higher ${ }^{7} \mathrm{Be}$ flux ratios seen in Table 4-4 and total inventory seen in Figure 4-4 as compared to the Fall 2004 and Spring 2006 sampling events. The extremely high values observed for the Fall 2005 event are likely due to influences from Hurricane Katrina as discussed in Section 4.6.

\subsection{Potential for Sediment Retention}

Using the project study area of 9,831 ac (3,978 ha) and an the estimated sediment influx of $2.9 \times 10^{6}$ tons $\left(2.6 \times 10^{9} \mathrm{~kg}\right)$ per year, potential yearly sedimentation rates can be estimated. Using a sediment porosity range of 55 to $75 \%$ and a dry sediment density of $2.27 \mathrm{t} / \mathrm{yd}^{3}$ (2,700 $\mathrm{kg} / \mathrm{m}^{3}$ ), potential yearly sedimentation ranges were calculated for $25 \%, 50 \%, 75 \%$, and $100 \%$ retention (also referred to as trapping efficiency) and presented in Table 4-5.

Table 4 - 5. Estimated Potential Sedimentation Rates

\begin{tabular}{|c|c|c|c|c|c|c|}
\hline \multirow{2}{*}{$\begin{array}{c}\% \\
\text { Retention }\end{array}$} & \multicolumn{2}{|c|}{ inches per year } & \multicolumn{2}{c|}{ cm per year } & \multicolumn{2}{c|}{$\begin{array}{c}\text { cm per month if } \\
\text { deposited over 6 months }\end{array}$} \\
\cline { 2 - 7 } & Minimum & Maximum & Minimum & Maximum & Minimum & Maximum \\
\hline $25 \%$ & 0.5 & 1.0 & 1.3 & 2.4 & 0.22 & 0.40 \\
\hline $50 \%$ & 1.1 & 1.9 & 2.7 & 4.8 & 0.45 & 0.81 \\
\hline $75 \%$ & 1.6 & 2.9 & 4.0 & 7 & 0.67 & 1.21 \\
\hline $100 \%$ & 2.1 & 3.8 & 5.4 & 10 & 0.90 & 1.61 \\
\hline
\end{tabular}

Comparison of these calculations with sediment accumulation patterns discussed in Section 4.2 suggests that retention of fine sediment entering West Bay from the diversion is on the order of $25-50 \%$ of the total sediment supply. Therefore, even though it is likely that most of the coarse sediment entering the project area is being retained, it is estimated that between $50 \%$ and $75 \%$ ( $25-50 \%$ trapping efficiency) of the total sediment load is bypassing the project area and possibly being transported out onto the shelf (Figs 3-55 through 3-57). This pattern is 
consistent with deltaic sequence described by Scruton (1960), where prodelta clays prograde out onto the shelf ahead of the delta front.

\subsection{Sediment Dispersal}

While characterization of riverine sediment supply to West Bay is essential, understanding sediment dispersal patterns is of equal importance. Estuarine sediment transport processes can be complex and affected by many factors such as sediment supply, water depth, salinity, water column velocities, bed shear stress, winds, and tides. Wright and Nittrouer (1995) recognize at least four stages (expanded to five stages by Rotondo, 2004) in the dispersal of sediment once it leaves the river mouth. Stage I is the initial deposition of bedload and flocculated sediments at the mouth of a river within an estuary or by such as West Bay. Stage II (a, b) is the supply of sediment via buoyant plumes (either positive or negative) and stage III is the initial deposition of the sediment on the shelf. Stage IV is re-suspension (by waves, currents, or slope failure mechanisms) and further transport of the recently deposited sediment, either in the water column (IVa) or as a gravity-driven flow (IVb). Stage IV may occur a number of times before finally arriving at stage V: long-term net accumulation of sediment.

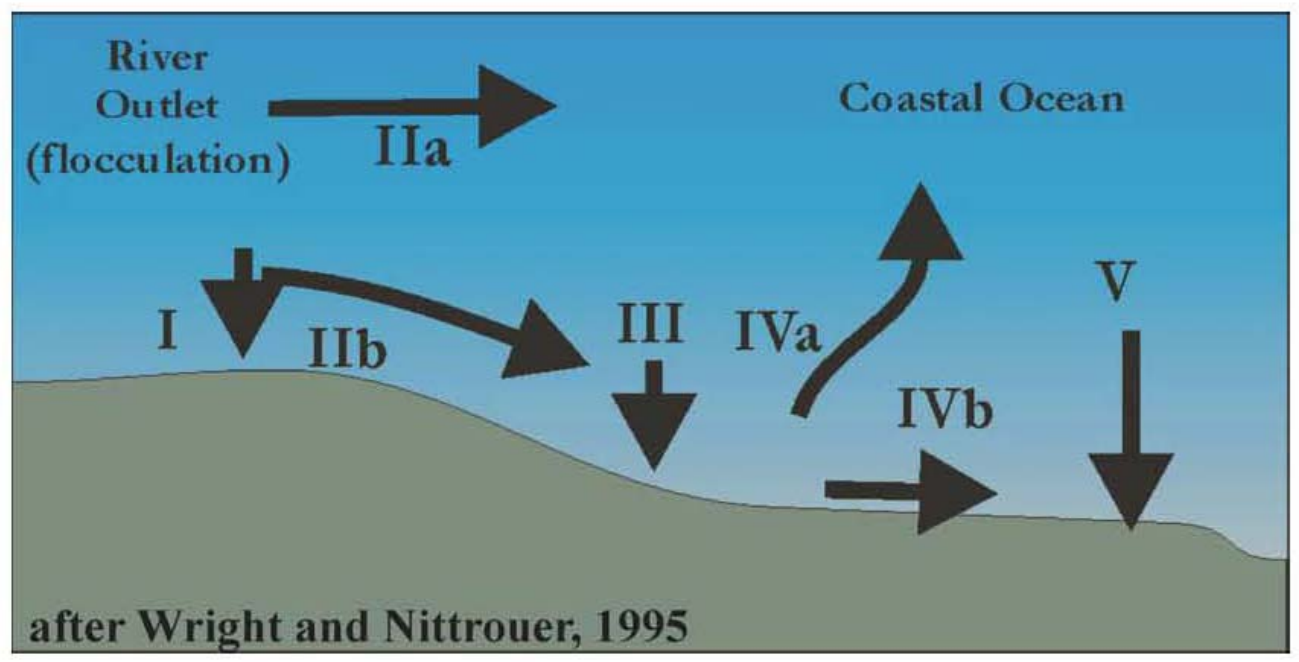

Figure 4-2. Conceptual Illustration of Five Major Stages in River Sediment Dispersal (Wright and Nittrouer, 1995; modified by Rotondo 2004) 
Wright and Nittrouer (1995) characterized initial plume dispersal for the Mississippi River as positively buoyant suspended sediment with low settling velocities resulting in initial deposition relatively far from the plume source. Walker (1989) observed the Mississippi River sediment plume $(>10 \mathrm{mg} / \mathrm{l})$ as far west as 60 miles $(97 \mathrm{~km})$. With the outer limits of the West Bay study area $<4.5$ miles $(7 \mathrm{~km})$ from the mouth of the diversion, it is likely that the majority of fine suspended sediments bypass the study area (Figs. 3-54 through 3-56). However, initial deposition of the coarsest material (fine sand, coarse silt) likely takes place roughly four channel widths (currently $2200 \mathrm{ft}$ or $670 \mathrm{~m}$ ) into the bay from the mouth of the diversion (Wright and Coleman, 1974). It is expected that the coarser deposits will move further out as the diversion distributary channel develops and progrades into the bay, for which evidence has already been seen (Fig. 3-27).

The Mississippi River plume represents a classic salt wedge, highly stratified estuary (Wright, 1971; Dyer, 1995) where the freshwater plume overlies denser coastal waters. A turbidity maximum can develop near the null point, or initial interface near the head of saltwater intrusion, where turbulent mixing occurs. Flocculation of cohesive sediments develops when positively charged cations present in salt water neutralize negative charges in freshwater, allowing molecular attractive van der Waals forces to dominate between clay particles. This process is also affected by the presence of organic matter which helps to hold flocs together (Dyer, 1995). This process could potentially occur in West Bay when salt water moves into the study area as seen in Figure 3-50.

Within the turbidity maximum zone, SSC can increase by orders of magnitude above background values, thereby increasing floc sizes and settling velocities. SSC and floc sizes within the turbidity maximum also vary with tidal range magnitudes and spring / neap cycles 
(Manning et al., 2006). Estuaries with small tidal ranges like in coastal Louisiana which has a maximum tidal range of 1.3 feet $(0.4 \mathrm{~m})$ (Wright et al., 1997) generally produce SSC on the order of 100 - $200 \mathrm{mg} / \mathrm{l}$ within turbidity maximums as opposed to macro tidal estuaries which have much higher concentrations, on the order of 1000 - 10,000 mg/l (Dyer 1995).

Flow through the diversion is considered fully turbulent as determined by the Reynolds number $R e$ for open channel flow (Roberson and Crowe, 1993):

$$
\operatorname{Re}=\mathrm{UR}_{\mathrm{h}} / \mathrm{v}
$$

Where velocities U measured during the LSU CSI flow study averaged $1.4 \mathrm{ft} / \mathrm{s}(0.4 \mathrm{~m} / \mathrm{s})$, the hydraulic radius $\left(\mathrm{R}_{\mathrm{h}}\right)$ (ratio of the cross sectional flow area to the wetted perimeter) is 22, and the kinematic viscosity $(\mathrm{v})$ is $10^{-5} \mathrm{ft}^{2} / \mathrm{s}\left(10^{-6} \mathrm{~m}^{2} / \mathrm{s}\right)$. Estimated $R e$ is on the order of $3 \times 10^{6}$ which is much greater than the critical Re of 750 for open channel flow, which indicates the transition between laminar and turbulent flow.

Critical current speeds to erode coarse silts / fine sands from the bay bottom are on the order of $0.004 \mathrm{ft} / \mathrm{s}(0.012 \mathrm{~m} / \mathrm{s})$ once deposited (van Rijn, 1984). Higher velocities are potentially needed to erode cohesive clays depending on bed shear stress, which could be highly variable. The quadratic stress law is used to approximate bed shear flow velocity (U*) using velocities at or just above the bottom boundary layer ( $\left.\overline{\mathrm{U}}_{100}\right)$ (1 m above the bed):

$$
\mathrm{U}^{*}=\mathrm{C}_{100}{ }^{1 / 2} \overline{\mathrm{U}}_{100}
$$

$\mathrm{C}_{100}$ is a dimensionless drag coefficient with a value of 0.0031 used in most applications 
(Sternberg, 1972). This results in a $\bar{U}_{100}$ velocity of $0.71 \mathrm{ft} / \mathrm{s}(0.22 \mathrm{~m} / \mathrm{s})$ for a critical bed shear velocity $\mathrm{U}_{*}$ of $0.004 \mathrm{ft} / \mathrm{s}(0.012 \mathrm{~m} / \mathrm{s})$. Based on the observed diversion velocities during the LSU CSI study, erosion occurred at the mouth of the diversion as indicated in the post-construction surveys (Fig. 3-27).

For sheet flow in estuaries such as West Bay, Re is given as (Leeder, 1982):

$$
R e=\mathrm{UL} / \mathrm{v}
$$

$\mathrm{L}$ is the depth of flow and the critical Re for turbulent flow is 2000. Using and average bay depth of $6.5 \mathrm{ft}(2 \mathrm{~m})$ the velocity $(\mathrm{U})$ which would achieve this critical $R e$ is $0.003 \mathrm{ft} / \mathrm{s}(0.001$ $\mathrm{m} / \mathrm{s}$ ) which is much less than the velocities seen in Figures 3-46 and 3-47. Therefore, flows seen at the mid-bay instrument are also considered turbulent.

Velocities measured approximately $3.3 \mathrm{ft}(1.0 \mathrm{~m})$ above the bottom at the instrument ranged from $0.06 \mathrm{ft} / \mathrm{s}(0.02 \mathrm{~m} / \mathrm{s})$ to $2.04 \mathrm{ft} / \mathrm{s}(0.62 \mathrm{~m} / \mathrm{s})$ with an average of $0.74 \mathrm{ft} / \mathrm{s}(0.22 \mathrm{~m} / \mathrm{s})$. The measured mid-bay velocities were compared against theoretical flows resulting from the diversion reaching this location in the bay by using the continuity equation in its simplest form (excluding bottom friction, hydraulic head differential, and other factors affecting velocity):

$$
\mathrm{Q}=\mathrm{VA}
$$

Where the maximum diversion flow $\mathrm{Q}$ is $41,100 \mathrm{ft}^{3} / \mathrm{s}\left(1,160 \mathrm{~m}^{3} / \mathrm{s}\right)$ (Table 4-2) and the cross-sectional flow area is $2.2 \times 10^{6} \mathrm{ft}^{2}\left(0.2 \times 10^{6} \mathrm{~m}^{2}\right)$ measured from post construction survey line 7-8 in Appendix E. This results in a theoretical velocity of $0.02 \mathrm{ft} / \mathrm{s}(0.006 \mathrm{~m} / \mathrm{s})$. Even 
though these velocities are lower than those observed at the mid-bay site, they are near the critical depositional velocity for coarse silt (Stoke's settling velocity is $\sim 0.003 \mathrm{~m} / \mathrm{s}$ for coarse silt). Therefore, at maximum diversion flows, not considering potential resuspension by waves, coarse silts could be transported to the mid-bay region. At less than at maximum diversion flows, other coastal forcing mechanisms such as tidal and wind driven currents dictate sediment transport patterns a relatively short distance from the mouth of the diverson due to the open geometry of West Bay.

Comparisons were also made between the mid-bay and diversion turbidity/SPM data sets (Figs. 3-44 and 3-45). Overall, the estimated SPM values compared well with those estimated from satellite measurements by Walker $(1996,2005)$ at similar river flows. It is possible that the gradual decrease in turbidities observed at the diversion could be a result of sensor fouling. However, it is more likely that the turbidity is decreasing with river flow measured upstream of the diversion which dropped over 100,000 $\mathrm{ft}^{3} / \mathrm{s}\left(2,830 \mathrm{~m}^{3} / \mathrm{s}\right)$ between January and February 2006 (Fig. 3-39). River flow then increased back up by over 100,000 ft³ $/ \mathrm{s}\left(2,830 \mathrm{~m}^{3} / \mathrm{s}\right)$ from February to March and peaking in April 2006. This subsequent flow increase likely caused the increase in turbidity seen at the end of the diversion data set (Fig. 3-44) which continued into the mid-bay data set (Fig. 3-45) and peaked in late March.

Initial measurements of turbidity at the mid-bay site on March 7, 2006 correlated very closely with turbidity measurements from the diversion on the same day just after relocation from the diversion to mid-bay. This is an indication that diversion flows are reaching the midbay location quickly and that baseline SPM values from the middle of the bay probably track closely with those entering the bay through the diversion without much lag time. Fluctuations in turbidity, and therefore estimated SPM, are however much more extreme at the mid-bay location 
than at the diversion. This indicates re-suspension of bay-bottom sediments resulting from tides and/or waves.

Winds over shallow waters can generate waves and significant sediment re-suspension. Maximum wave orbital velocities $\left(\mathrm{u}_{b \max }\right.$ ) occur at the top of the wave boundary layer and decrease as orbital velocities near the bed due to friction. Maximum wave orbital velocities near the bed ( $\left.\mathrm{u}_{b \max }\right)$ can be calculated using Equation 11 and then be used to determine the shear velocity due to wave action $\left(\mathrm{U}^{*} \mathrm{w}\right)$ (Wright, 1989).

$$
\mathrm{u}_{b \max }=\pi \mathrm{H} / \mathrm{T} \sinh (2 \pi \mathrm{h} / \mathrm{L})
$$

where: $\mathrm{L}$ is the wavelength, $\mathrm{H}$ is the wave height, $\mathrm{T}$ is the wave period, and $\mathrm{h}$ is the water depth. Deep-water fetch limited equations for wave height and period were modified to include bottom friction effects by Bretschneider and Reid (1954). Equations 3-39 and 3-40 in the USACE Shoreline Protection Manual (1984) can be used to calculate wave heights (H) and wave periods (T) for given wind speeds. The wavelength (L) can be determined by its relationship with the wave number $(k)$ given in Equation 12. The wavenumber $(k)$ varies for shallow and deepwater cases and can be determined through an explicit approximation suggested by Hunt (1979).

$$
k=2 \pi / L
$$

At any given location, critical wind speeds for sediment re-suspension can be determined by water depths and fetch, or unbroken wind distance. Wind speeds used to calculate $\mathrm{H}, \mathrm{T}$, and $\mathrm{L}$ are considered to be $10 \mathrm{~m}\left(\mathrm{U}_{10}\right)$ above the sea surface. Wind speeds measured at Southwest 
Pass (Fig. 3-52) were recorded at $30 \mathrm{~m}\left(\mathrm{U}_{30}\right)$ above the sea surface. Figure II-2-6 from the Coastal Engineering Manual (USACE, 2001) was used to convert $U_{30}$ to $U_{10}$ assuming air-sea air temperature difference is $0^{\circ} \mathrm{C}$. Predominant wind speeds at the study site from 2003 to 2006 originate from the NNE and the SE (Fig. 3-52). At the bay shoreline edges (Case 1) in water depths of 3 feet $(1 \mathrm{~m})$, fetches average around 18,500 feet $(5640 \mathrm{~m})$. In the middle of the bay (Case 2) where water depths average 6.5 feet $(2 \mathrm{~m})$, fetches average 12,000 feet $(3,660 \mathrm{~m})$. Using equations the Demonstration Sediment-Transport Applets made available by the USGS at http://woodshole.er.usgs.gov/staffpages/csherwood/sedx_equations/sedxinfo.html, maximum wave orbital velocities $\left(\mathrm{u}_{b \max }\right)$ and shear velocity due to wave action $\left(\mathrm{U}^{*} \mathrm{w}\right)$ were calculated for a range of wind speeds for Cases 1 and 2 and summarized in Table 4-6.

Table 4 - 6. Estimation of Near-Bottom Orbital Velocities for Various Wind Conditions

\begin{tabular}{|c|c|c|c|c|c|c|c|c|c|}
\hline \multicolumn{8}{|c|}{ Case 1: Bay Edges (Fetch $5.6 \mathrm{~km}$, Water Depth $=1 \mathrm{~m})$} \\
\hline $\begin{array}{c}\mathrm{U}_{30} \\
(\mathrm{knots})\end{array}$ & $\begin{array}{c}\mathrm{U}_{30} \\
(\mathrm{~m} / \mathrm{s})\end{array}$ & $\begin{array}{c}\mathrm{U}_{10} \\
(\mathrm{~m} / \mathrm{s})\end{array}$ & $\begin{array}{c}\mathrm{h} \\
(\mathrm{m})\end{array}$ & $\begin{array}{c}\mathrm{H} \\
(\mathrm{m})\end{array}$ & $\begin{array}{c}\mathrm{T} \\
(\mathrm{s})\end{array}$ & $k$ & $\begin{array}{c}\mathrm{L} \\
(\mathrm{m})\end{array}$ & $\begin{array}{c}\mathrm{U}_{\text {max }} \\
(\mathrm{m} / \mathrm{s})\end{array}$ & $\begin{array}{c}\mathrm{U}^{*} \mathrm{~W} \\
(\mathrm{~m} / \mathrm{s})\end{array}$ \\
\hline \hline 1 & 0.5 & 0.5 & 1.0 & 0.00 & 0.23 & 76.1 & 0.1 & 0.000 & 0.000 \\
\hline 4 & 2.1 & 1.9 & 1.0 & 0.05 & 0.89 & 5.08 & 1.2 & 0.002 & 0.000 \\
\hline 7 & 3.6 & 3.2 & 1.0 & 0.09 & 1.21 & 2.78 & 2.3 & 0.030 & 0.005 \\
\hline 11 & 5.7 & 5.1 & 1.0 & 0.15 & 1.51 & 1.86 & 3.4 & 0.100 & 0.013 \\
\hline 17 & 8.7 & 7.7 & 1.0 & 0.22 & 1.80 & 1.40 & 4.5 & 0.199 & 0.021 \\
\hline 21 & 10.8 & 9.5 & 1.0 & 0.26 & 1.95 & 1.23 & 5.1 & 0.267 & 0.023 \\
\hline
\end{tabular}

\begin{tabular}{|c|c|c|c|c|c|c|c|c|c|}
\hline \multicolumn{10}{|c|}{ Case 2: Mid Bay (Fetch $=3.7 \mathrm{~km}$, Water Depth $=2 \mathrm{~m})$} \\
\hline $\begin{array}{c}\mathrm{U}_{30} \\
(\mathrm{knots})\end{array}$ & $\begin{array}{c}\mathrm{U}_{30} \\
(\mathrm{~m} / \mathrm{s})\end{array}$ & $\begin{array}{c}\mathrm{U}_{10} \\
(\mathrm{~m} / \mathrm{s})\end{array}$ & $\begin{array}{c}\mathrm{h} \\
(\mathrm{m})\end{array}$ & $\begin{array}{c}\mathrm{H} \\
(\mathrm{m})\end{array}$ & $\begin{array}{c}\mathrm{T} \\
(\mathrm{s})\end{array}$ & $k$ & $\begin{array}{c}\mathrm{L} \\
(\mathrm{m})\end{array}$ & $\begin{array}{c}\mathrm{U}_{\text {bmax }} \\
(\mathrm{m} / \mathrm{s})\end{array}$ & $\begin{array}{c}\mathrm{U}^{*} \mathrm{~W} \\
(\mathrm{~m} / \mathrm{s})\end{array}$ \\
\hline \hline 1 & 0.5 & 0.5 & 2.0 & 0.00 & 0.23 & 76.1 & 0.1 & 0.000 & 0.000 \\
\hline 4 & 2.1 & 1.9 & 2.0 & 0.04 & 0.86 & 5.44 & 1.2 & 0.000 & 0.000 \\
\hline 7 & 3.6 & 3.2 & 2.0 & 0.09 & 1.17 & 2.94 & 2.1 & 0.001 & 0.000 \\
\hline 11 & 5.7 & 5.1 & 2.0 & 0.15 & 1.47 & 1.87 & 3.4 & 0.015 & 0.003 \\
\hline 17 & 8.7 & 7.7 & 2.0 & 0.24 & 1.75 & 1.33 & 4.7 & 0.061 & 0.008 \\
\hline 21 & 10.8 & 9.5 & 2.0 & 0.30 & 1.91 & 1.13 & 5.6 & 0.104 & 0.012 \\
\hline
\end{tabular}

The critical shear velocity $\left(\mathrm{U}^{*}\right)$ to re-suspend coarse silts / fine sands from the bay bottom are on the order of $0.004 \mathrm{ft} / \mathrm{s}(0.012 \mathrm{~m} / \mathrm{s})$ once deposited (van Rijn, 1984). For Case 1 at 
the bay edges, $\mathrm{U}^{*}$ is exceeded for an $11 \mathrm{knot}(5.7 \mathrm{~m} / \mathrm{s}) \mathrm{U}_{30}$ wind. For Case 2 at the middle of the bay, $\mathrm{U}^{*}$ is exceeded for a $21 \mathrm{knot}(10.8 \mathrm{~m} / \mathrm{s}) \mathrm{U}_{30}$ wind. The average wind speed observed at Southwest Pass (Fig. 3-52) during the study period was 12.2 knots $(6.3 \mathrm{~m} / \mathrm{s})$ which exceeds the critical wind speed needed for re-suspension of coarse silt / fine sand for Case 1 at the bay edges. For Case 2 in the middle of the bay, 21 knot $(10.8 \mathrm{~m} / \mathrm{s}) \mathrm{U}_{30}$ winds were exceeded during approximately 5-10\% of the study period (Hurricane Katrina not included).

Where finer sediments are present, bed shear stress can be higher than coarse silts and sands, due the cohesive nature of clay sediments. A typical range of critical shear stresses $\left(\tau_{c}\right)$ for surficial muds is between 0.06 and $0.1 \mathrm{~N} / \mathrm{m}^{2}$ (Dyer, 1995). A U* can be calculated to erode muddy sediment (Wright, 1989):

$$
\mathrm{U}^{*}=\left(\tau_{\mathrm{c}} / \rho_{f}\right)^{1 / 2}
$$

Where: $\rho_{f}$ is the density of water $\left(1,000 \mathrm{~kg} / \mathrm{m}^{3}\right.$ for freshwater). A intermediate value of 0.08 $\mathrm{N} / \mathrm{m}^{2}$ for $\tau_{\mathrm{c}}$ produces a $\mathrm{U}^{*}$ of $0.029 \mathrm{ft} / \mathrm{s}(0.009 \mathrm{~m} / \mathrm{s})$ to re-suspend fine cohesive sediments. This occurs under waves generated by winds with speeds between 7 and 11 knots ( 3.6 and $5.7 \mathrm{~m} / \mathrm{s}$ ) for Case 1 and 17 and 21 knots (8.7 and $10.8 \mathrm{~m} / \mathrm{s}$ ) for Case 2. Figure 4-3 illustrates a summary the factors affecting sediment transport in the study area as discussed in this section.

\subsection{Seasonal and Spatial Patterns of Fluvial Influence}

The sediment retention patterns explored in Section 4.4 warrant a closer look at seasonal river and diversion flows and spatial depositional patterns within the study area. The strategy of the initial study plan was to track two (2) normal cycles of the Mississippi River hydrograph by timing sampling events with rising and falling limbs of river flow. Figure 4-4 illustrates the river 


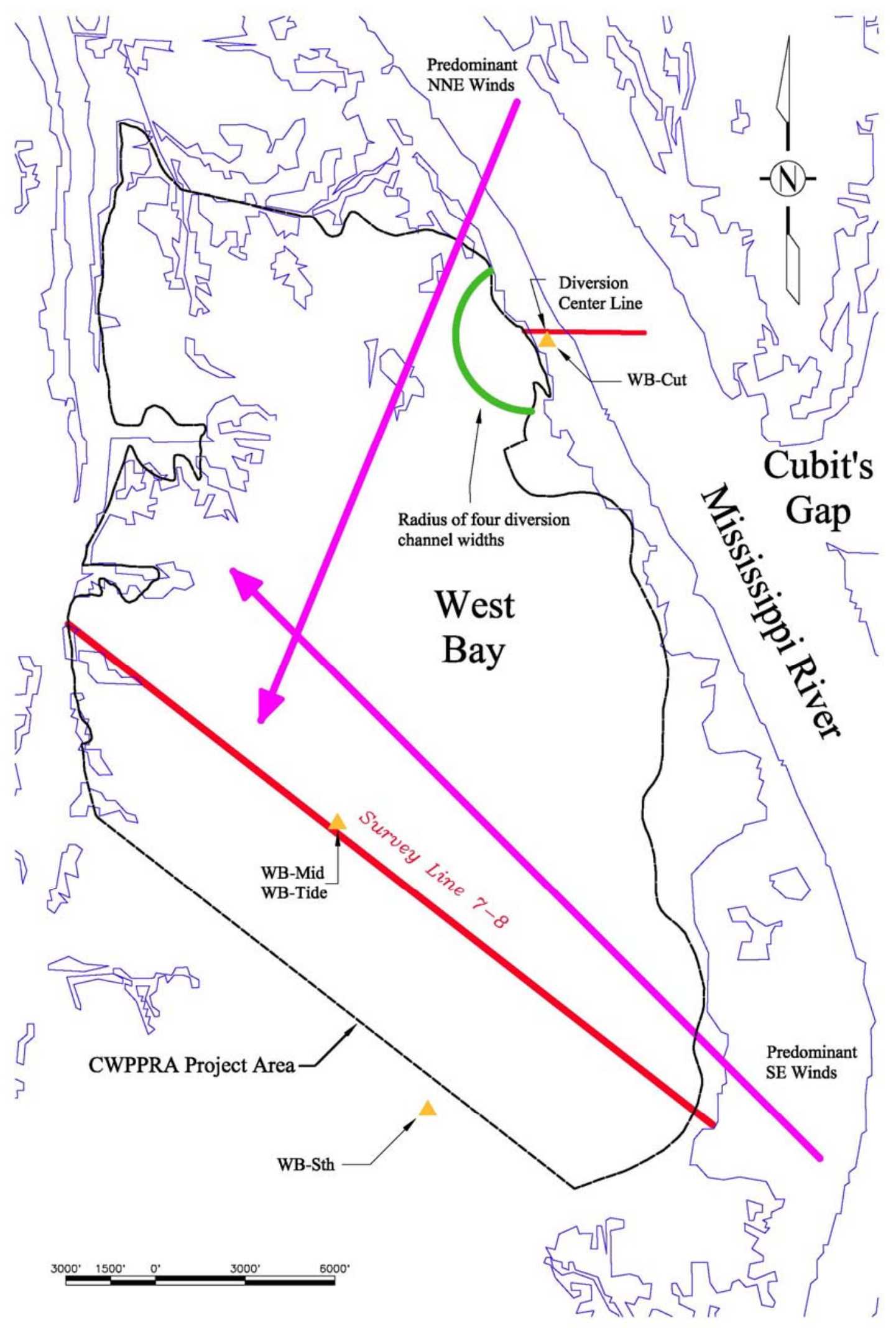

Figure 4-3. Illustration of Sediment Dispersal Considerations in the West Bay Study Area 


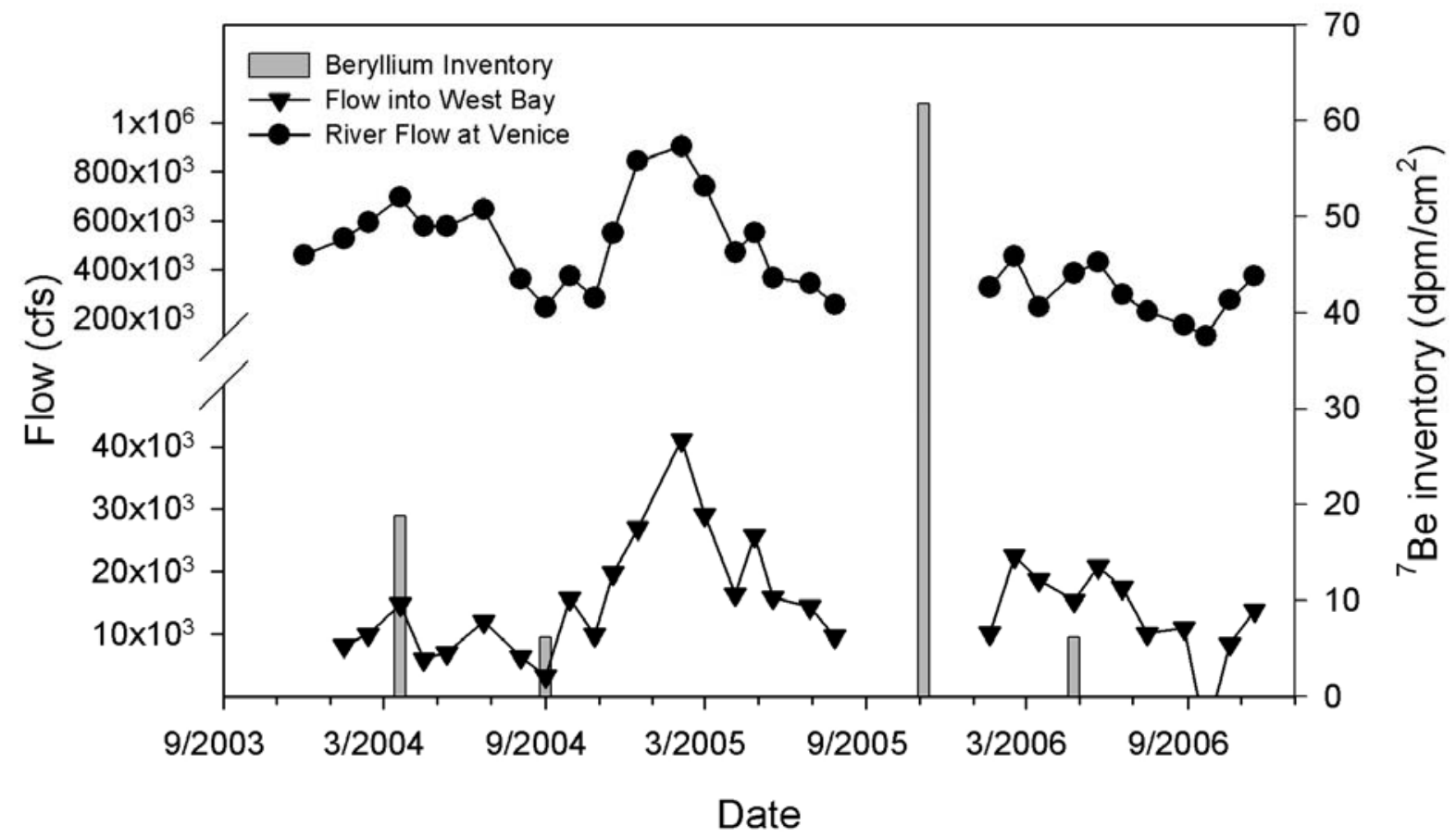

Figure 4-4. West Bay Flow and Total ${ }^{7}$ Be Inventory Analysis

Note: Total ${ }^{7}$ Be inventories were calculated by summing all inventories in cores from stations that were cored for each sampling event.

and diversion flow hydrographs (in cfs) along with total ${ }^{7}$ Be inventories in $\mathrm{dpm} / \mathrm{cm}^{2}$ for each sampling event. Total inventories were calculated by summing inventories from core sampling stations which were replicated for each sampling event. The 2004 river hydrograph displayed a predictable pattern comparable to the historical river hydrograph (Fig. 3-29), however during 2005 irregular flow patterns were encountered. The Spring 2005 flow peak was significantly higher than those of the 2004 and 2006 Spring seasons. No flow data were collected from August to December of 2005 due to Hurricane Katrina. However, the highest total ${ }^{7}$ Be inventory was calculated during this time period, suggesting the combined effects of enhanced atmospheric ${ }^{7}$ Be scavenging, sediment resuspension, deposition, and physical mixing. The total inventories from the Spring 2004, Fall 2004, and Spring 2006 appear to track river flows and to a lesser 
extent, diversion flows. For example, the Spring 2004 samples resulted in more than twice the ${ }^{7}$ Be inventory than that of the Spring 2006 samples which were taken during higher diversion flows but a lower river stage. This supports the hypothesis that river flows and sediment loads are entering the study area through more avenues than just the diversion. River flows were measured at Venice near "the Jump" where a portion of the flow is diverted to Grand Pass which borders the study area on the western margin.

Figure 4-5 shows maps of ${ }^{7}$ Be inventories for each station from all four sampling events. In the figure, the sizes of the circles centered at the core sites are proportional to the ${ }^{7} \mathrm{Be}$ inventory amounts detected. The highest inventories are interpreted to represent the most rapid sediment deposition. The magnitudes and distribution patterns appear to be related to the river hydrograph and corresponding diversion flows summarized in Figure 4-4 as well as hurricane related deposition and mixing. The Spring 2004 samples were taken after a river hydrograph peak of approximately $550,000 \mathrm{ft}^{3} / \mathrm{s}\left(15,500 \mathrm{~m}^{3} / \mathrm{s}\right)$. Results for this sampling event suggest fresh sediment deposition along the western margin of the bay and show the highest ${ }^{7}$ Be inventories of our study, with the exception of the Fall 2005 samples which were taken approximately two months after Hurricane Katrina. The Fall 2004 and Spring 2006 samples were collected after river hydrograph lows of less than $200,000 \mathrm{ft}^{3} / \mathrm{s}\left(5,600 \mathrm{~m}^{3} / \mathrm{s}\right)$. These results support previous observations that at relatively low river levels, deposition still occurs in the middle of the bay which continues to be influenced by diversion flows. It is also evident throughout all sampling events that the majority of the sediment deposition is focused from the middle of the bay to the western margin. Coriolis forces could be playing a role in diverting inflowing river plumes toward the western edge of the bay, (Wright, 1995, p. 73) a pattern probably enhanced by winds blowing from the NE and SE quadrants (Fig. 3-52). This is also consistent with velocity flow 
SPRING 2004 BERYLLIUM INVENTORIES

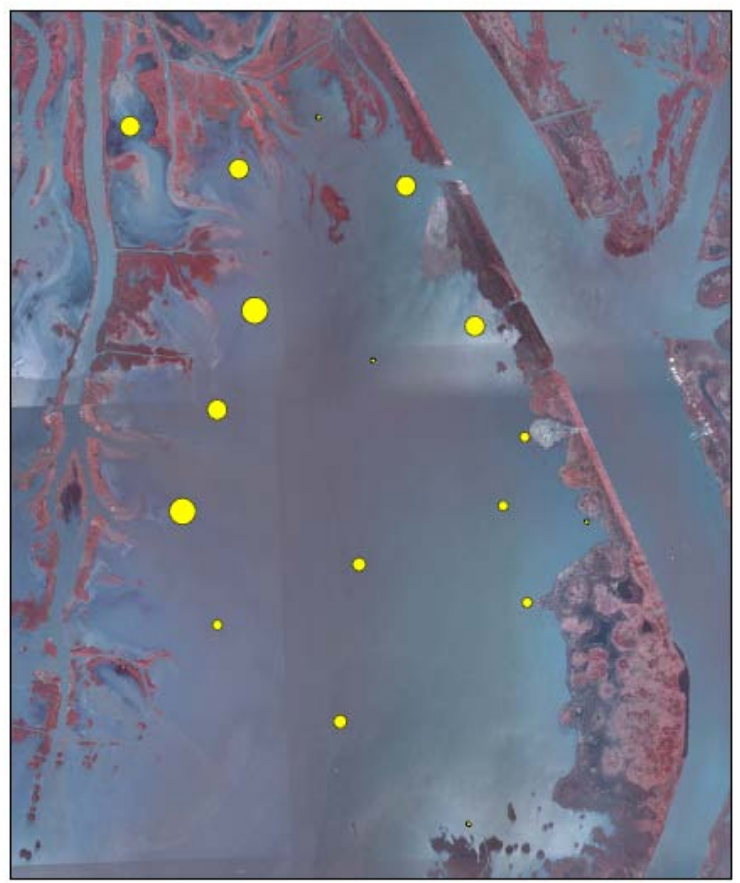

FALL 2005 BERYLLIUM INVENTORIES

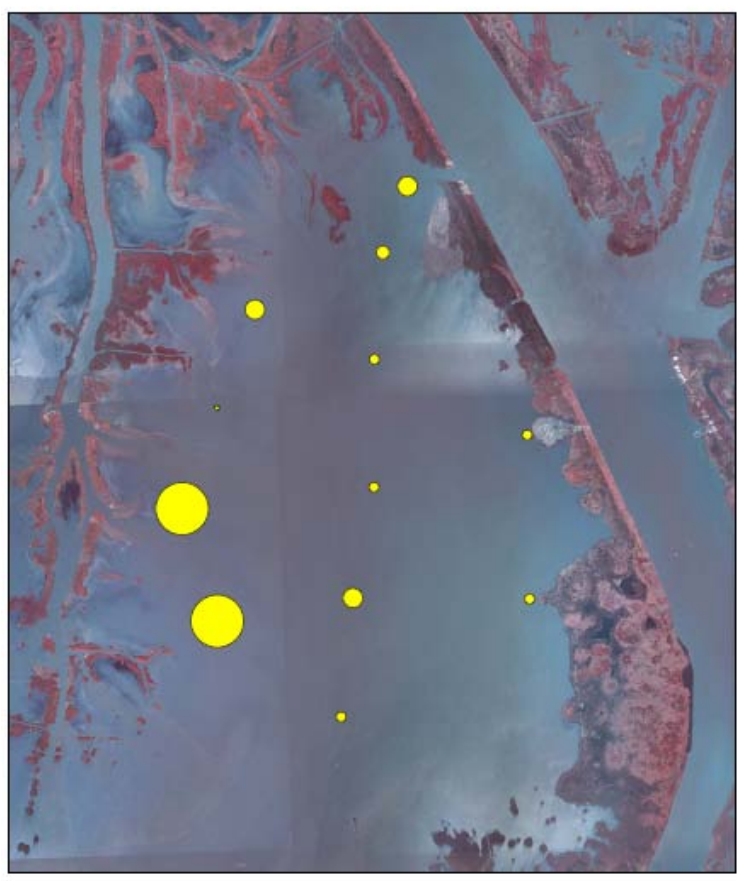

FALL 2004 BERYLLIUM INVENTORIES

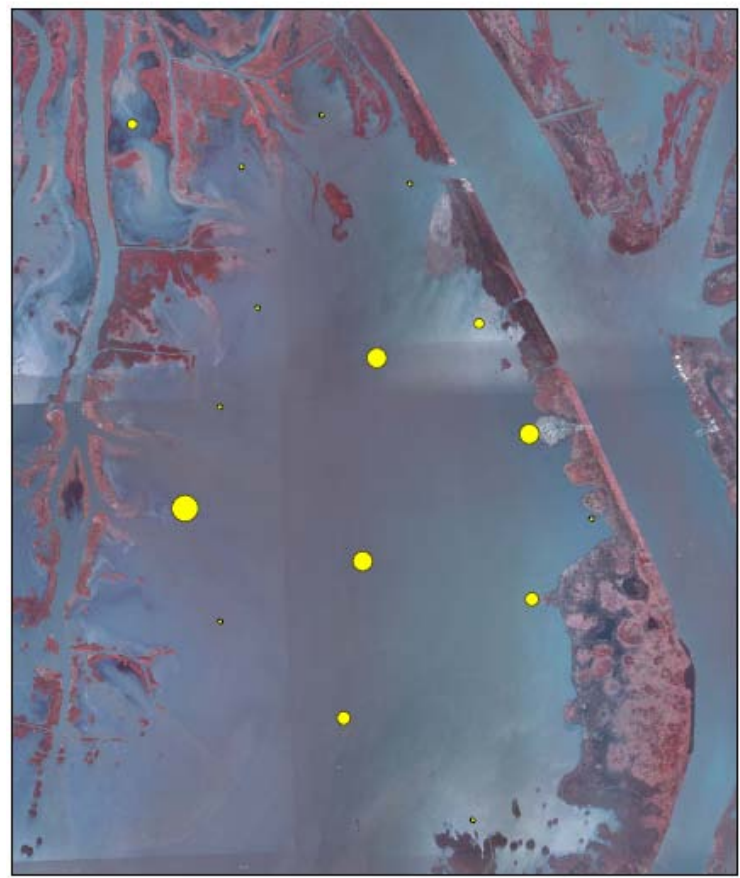

SPRING 2006 BERYLLIUM INVENTORIES

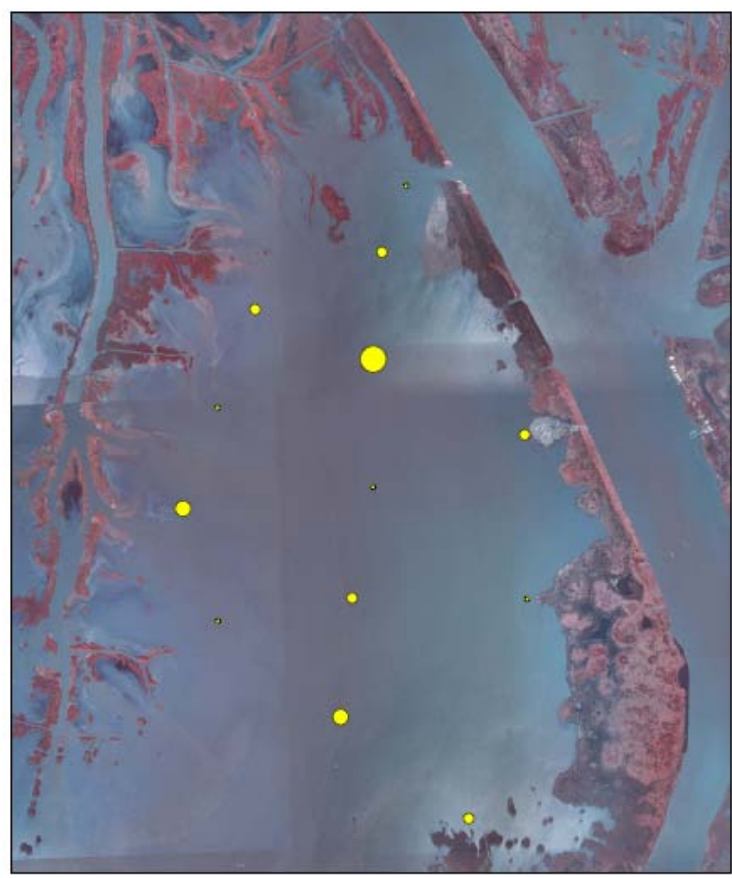

Figure 4-5. Spatial Distributions of ${ }^{7}$ Be Inventories 
directions (mostly to between 300 and 360 degrees in Figs. 3-46 and 3-47) recorded during the mid-bay instrument deployment.

\subsection{Storm Influences on Depositional Record}

Hurricane Katrina struck the Louisiana coast on August 29, 2005 transitioning from a Category 4 to a Category 3 storm on the Saffir-Simpson scale, with winds at landfall estimated at 110 knotts (57 m/s) (Sallenger et al, 2007). Prior to landfall, Katrina reached Category 5 status in the central Gulf of Mexico. Figure 4-6, illustrates the path of Hurricane Katrina through southeastern Louisiana and Mississippi as well as the spatial extent of hurricane force winds calculated by NOAA’s Hurricane Research Division in Miami, Florida. According to the track shown, the eye of storm passed approximately 15 nautical miles (28 km) to the west of the West Bay study area.

Because of the devastation to lower Plaquemines Parish, flow records were not recorded for six months following the hurricane, however the study team did manage to conduct a coring trip in November 2005. The results from these samples produced ${ }^{7}$ Be inventories of much greater proportions than those of the other three coring trips (Fig. 4-4). From this data and evidence of a substantial deposition layer seen in a number of the x-radiograph images taken during in the Fall 2005 and Spring 2006 (Figures 3-12 through 3-18), it is evident the extreme energy of the hurricanes transported copious amounts of sediment with coarser grain size than the sediment being delivered by the diversion or other sources. This is supported by grain size data presented in Section 3.2.5. The larger grain sizes seen in the Fall 2005 averages are likely attributable to an influx of coarse material transported and deposited by Hurricane Katrina. As this coarse material was re-worked and covered by sedimentation, the average median grain size 
dropped in Spring 2006, but was still higher than pre-hurricane averages. This pattern is best illustrated at site WB05 in Figure 3-25.

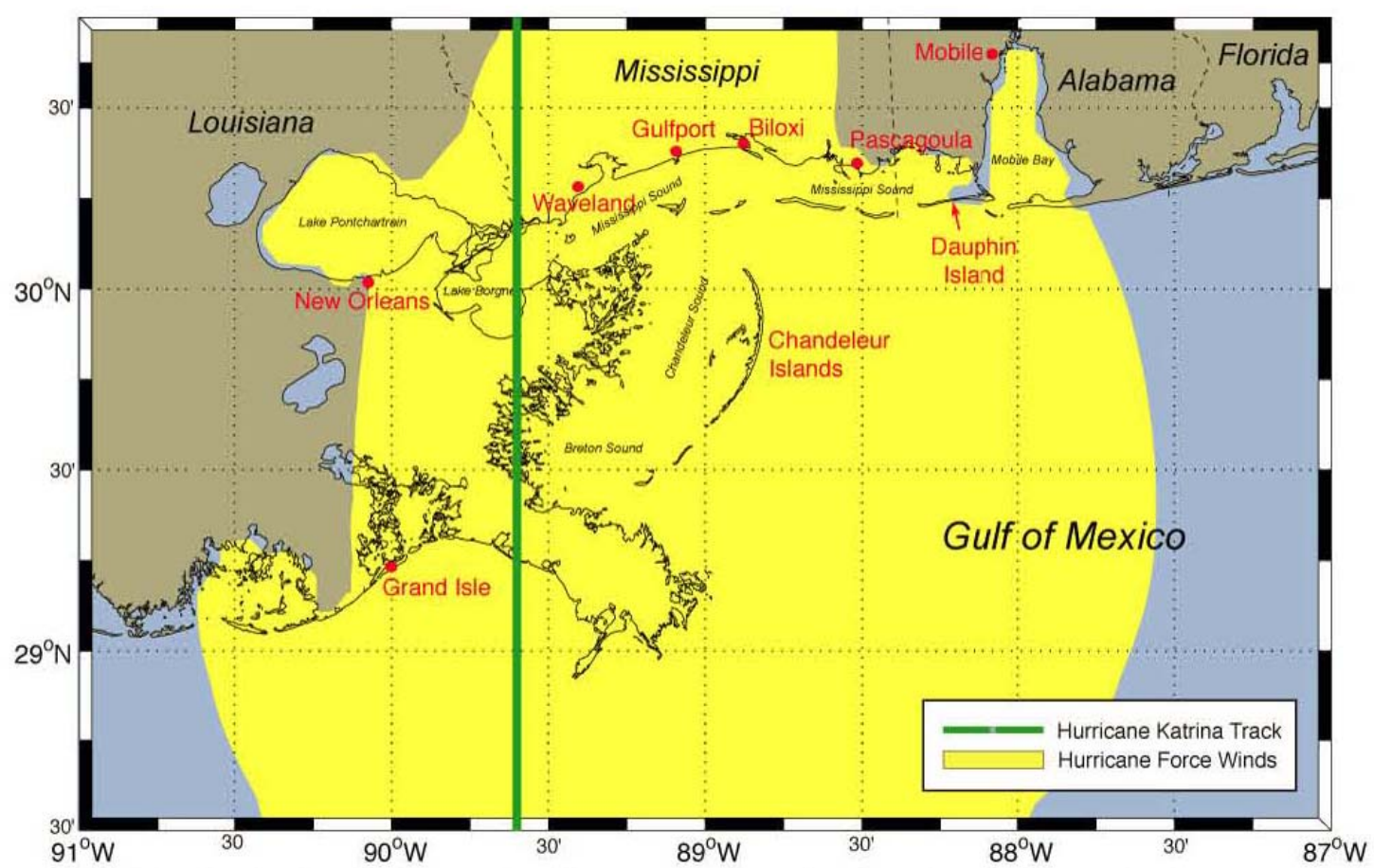

Figure 4-6. Track of Hurricane Katrina and Spatial Extent of Hurricane Force Winds (Sallenger et al., 2007)

This depositional layer followed massive amounts of erosion induced by storm surge currents and maximum wave heights. Comparison of pre and post storm cross sections in Appendix $G$ and bathymetric contours from Figures 3-26 and 3-27, respectively, indicate significant bay bottom erosion as deeper contours encroached inland and erosion of bay shorelines is evident. It is speculated that the majority of this erosion resulted from the hurricane, but this cannot be proven because no survey was conducted between the time of diversion construction and the time of Katrina’s landfall.

Erosional losses were further confirmed by performing a volumetric change analysis between the 2003 and 2006 surveys. Volumetric changes were calculated by overlaying cross sections from the two surveys that were acquired along the same profile lines. The area between 
the two cross sections was then measured using AutoCAD software. The difference area from each profile line was then averaged with adjacent profile lines and multiplied by the length between the lines. This results in volumetric changes between each line which are totaled resulting in an overall change volume for the calculation boundary shown in Figure 4-7. This is commonly referred to as the end area method (ASCE, 1998; ASCE, 2006; Breed and Hosmer, 1908) and is summarized in Table 4-7.

The calculations resulted in an estimated loss of $4.16 \times 10^{6} \mathrm{yd}^{3}\left(3.18 \times 10^{6} \mathrm{~m}^{3}\right)$ of sediment between 2003 and 2006. Assuming a sediment porosity of $65 \%$ and a dry sediment density of $2.27 \mathrm{t} / \mathrm{yd}^{3}\left(2,700 \mathrm{~kg} / \mathrm{m}^{3}\right)$, the estimated volume loss equates to $3.3 \times 10^{6}$ tons $\left(3.0 \times 10^{9}\right.$ $\mathrm{kg}$ ) of sediment. This estimated volume lost is greater than yearly average sediment influx of 2.9 x $10^{6}$ tons $\left(2.6 \times 10^{9} \mathrm{~kg}\right)$ estimated in Section 4.1. It is evident in Figure 3-27 that some of the calculated erosion can be attributed to diversion flows and channel evolution through the center of the bay. Additional erosional losses were likely caused by hurricane forces and the passage of winter cold fronts. Quantifying the differences between these causes of erosion could not be done because no survey data was collected between diversion construction and Hurricane Katrina.

The surveys and volume calculations also did not capture evidence of the sediment retention estimated in Section 4.2. Therefore, the sediment retention estimates could not be confirmed as near-surface depositional records were erased by the storm. The only location where erosion was not apparent was between survey lines 11-12 and 13-14. Table 4-7 indicates a post-storm accretion of just over $23,000 \mathrm{yd}^{3}\left(17,500 \mathrm{~m}^{3}\right)$ at that location. Even though this is less than $1 \%$ of the overall change volume estimated, it is an indicator that this area in the middle of the bay is likely a depositional focal point where diversion flows slow below critical settling 


\section{West Bay Erosional Volume Calculation Area}

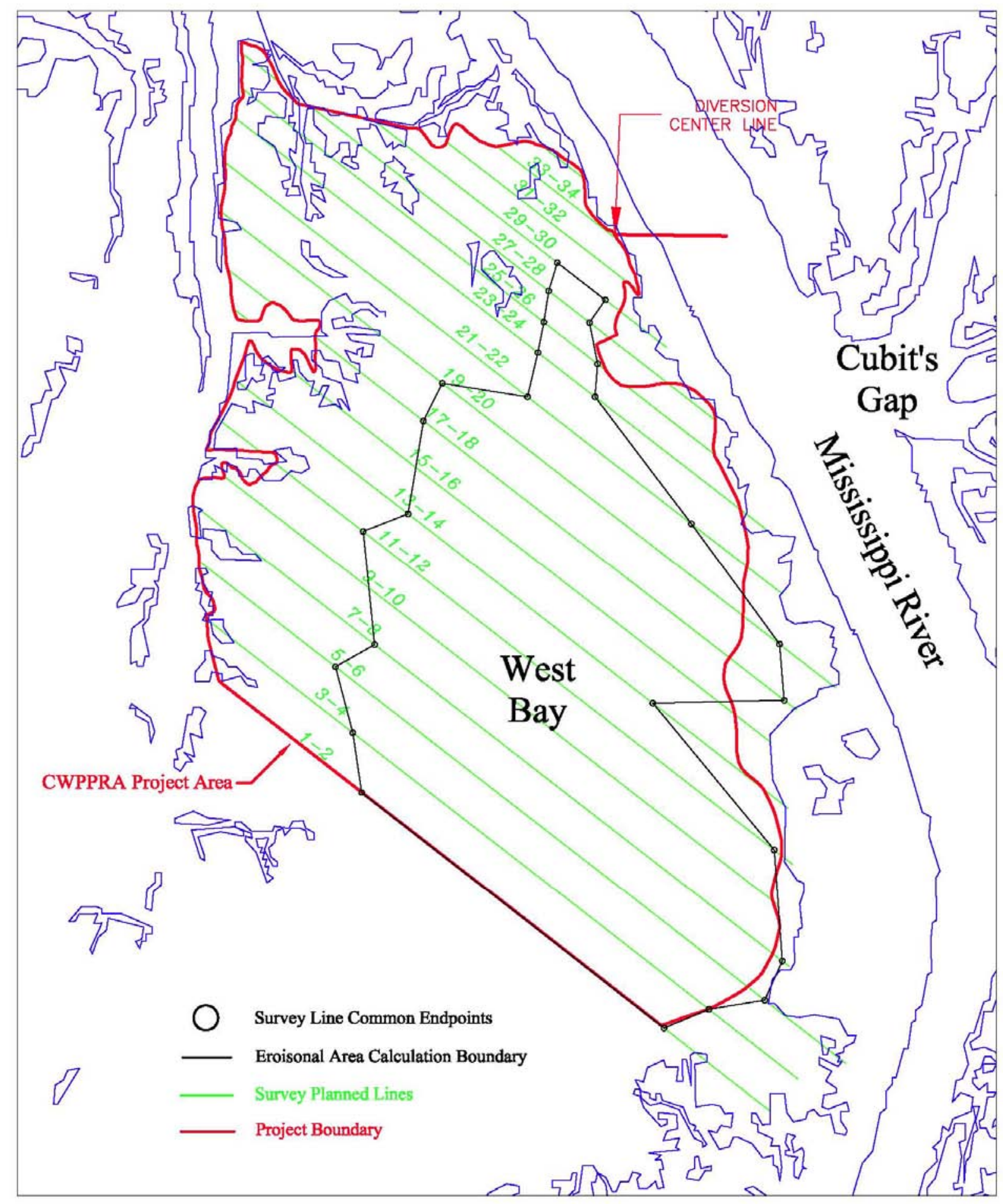

Figure 4-7. Plan View of Volumetric Change Calculation Area 
Table 4 - 7. Summary of Volumetric Change Calculations Using the End Area Method

\begin{tabular}{|c|c|c|c|c|c|}
\hline STATION & $\begin{array}{l}\text { AREA } \\
\left(\text { FT }^{2}\right) \\
\end{array}$ & $\begin{array}{c}\text { AREA } \\
\left(\mathrm{YD}^{3} / \mathrm{FT}\right) \\
\end{array}$ & $\begin{array}{c}\text { AVG AREA } \\
\left(\mathbf{Y D}^{3} / \mathbf{F T}\right) \\
\end{array}$ & $\begin{array}{c}\text { LENGTH } \\
\text { (FT) } \\
\end{array}$ & $\begin{array}{c}\text { VOLUME } \\
\left(\mathbf{Y D}^{3}\right) \\
\end{array}$ \\
\hline \multirow[t]{2}{*}{ Line 1-2 } & -7427.95 & -275.11 & & & \\
\hline & & & -249.53 & 1,500 & $-374,300$ \\
\hline \multirow[t]{2}{*}{ Line 3-4 } & -6046.83 & -223.96 & & & \\
\hline & & & -282.96 & 1,500 & $-424,433$ \\
\hline \multirow[t]{2}{*}{ Line 5-6 } & -9232.77 & -341.95 & & & \\
\hline & & & -245.64 & 1,500 & $-368,458$ \\
\hline \multirow[t]{2}{*}{ Line 7-8 } & -4031.71 & -149.32 & & & \\
\hline & & & -251.04 & 3,000 & $-753,119$ \\
\hline \multirow[t]{2}{*}{ Line $11-12$} & -9524.42 & -352.76 & & & \\
\hline & & & 15.49 & 1,500 & 23,236 \\
\hline \multirow[t]{2}{*}{ Line 13-14 } & 10360.91 & 383.74 & & & \\
\hline & & & -136.18 & 3,000 & $-408,533$ \\
\hline \multirow[t]{2}{*}{ Line $17-18$} & -17714.51 & -656.09 & & & \\
\hline & & & -594.39 & 1,500 & $-891,591$ \\
\hline \multirow[t]{2}{*}{ Line $19-20$} & -14382.78 & -532.70 & & & \\
\hline & & & -254.05 & 1,500 & $-381,073$ \\
\hline \multirow[t]{2}{*}{ Line 21-22 } & 664.16 & 24.60 & & & \\
\hline & & & -6.35 & 1,500 & $-9,528$ \\
\hline \multirow[t]{2}{*}{ Line $23-24$} & -1007.18 & -37.30 & & & \\
\hline & & & -107.48 & 1,500 & $-161,220$ \\
\hline \multirow[t]{2}{*}{ Line 25-26 } & -4796.74 & -177.66 & & & \\
\hline & & & -145.39 & 1,500 & $-218,079$ \\
\hline \multirow[t]{2}{*}{ Line 27-28 } & -3054.12 & -113.12 & & & \\
\hline & & & -131.12 & 1,500 & $-196,683$ \\
\hline Line 29-30 & -4026.48 & -149.13 & & & \\
\hline & & & & Total & $-4,163,782$ \\
\hline
\end{tabular}

velocities. This is best illustrated on the bay survey centerline shown on sheet 5 of Appendix $\mathrm{E}$ between stations 4,000 and 10,000. Cross sectional differences from station 10,000 to 20,000 are interpreted as erosion from diversion flows. Cross sectional differences from station 0 to 4,000 is interpreted as storm erosion. The cross sectional differences seen at the ends of most of the profile lines on sheets $1-5$ are also interpreted as storm erosion at the bay shoreline edges.

Following Hurricane Katrina, an additional coring study was being conducted by Tulane 
University on the Louisiana continental shelf adjacent to Southwest Pass (Allison et al., 2007). Box cores sampled in water depths of $<130 \mathrm{ft}(40 \mathrm{~m})$ of water and showed evidence of and erosional surface at the sediment-water interface, indicated this as the maximum water depth that the storm exerted critical bottom erosional stresses. In water depths of $>80 \mathrm{ft}(25 \mathrm{~m}), \mathrm{x}-$ radiographs taken from the box cores showed evidence of depositional event layers from 1 to 25 $\mathrm{cm}$ (0.4 to $9.8 \mathrm{in})$ thick above the basal erosional surface and were verified by the presence of ${ }^{7}$ Be. Most of these event layers displayed a fining upward sequence, indicative of gradual reduction of water column energies after the storm passage marking re-deposition of sediments suspended by the storm and runoff from the land surface associated with storm surge backflow. This pattern was further confirmed by the presence of fining upward sequences in the event layers overlying coarse basal layers resulting from gradually reducing backflow velocities (Allison et al., 2007). Figure 4-8 shows a map of the box core sites (indicated as circles) and interpreted erosional and depositional patterns. Areas are divided into 1) a region where shelf incision and no event layer were found (Erosion), 2) a region where shelf incision was followed by deposition of an event layer (1 Event), 3) a region similar to the 1 Event zone but where stacked earlier (Hurricane Ivan) and/or later (Hurricane Rita) event layers were also preserved (2+ Event), and 4) a deeper region where no shelf incision was observed and event layers were documented or no impact was observed (Deposition/No Impact).

Post-Katrina x-radiographs from West Bay displayed similar erosional patterns to those in the Tulane study. Depositional patterns were seen in some of the x-radiographs also showed similar patterns of coarse basal layers just above the erosional surface and fining upward sequences. The main difference is that the Tulane cores showed no deposition in $<80 \mathrm{ft}(25 \mathrm{~m}$ ) 


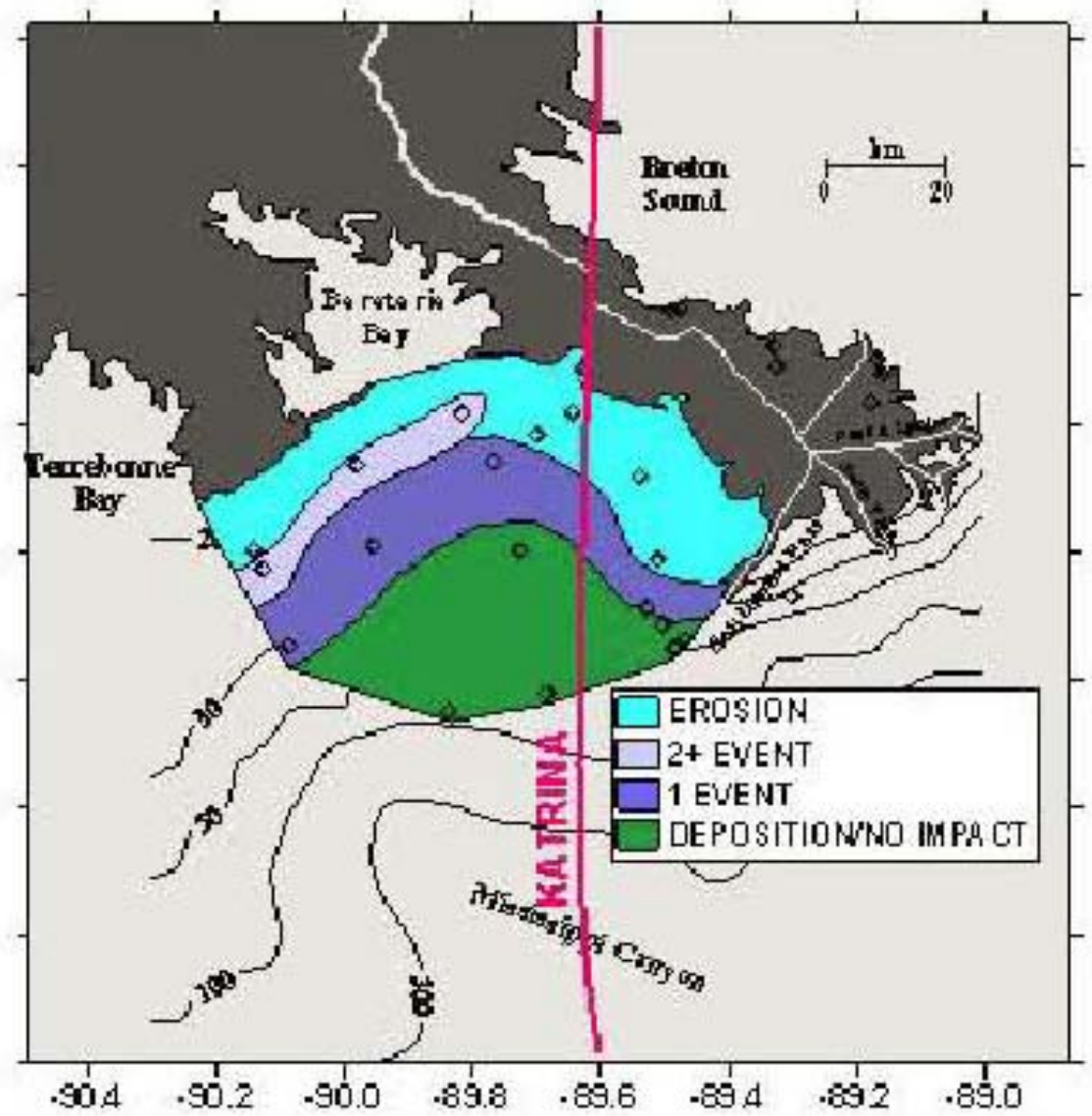

Figure 4-8. Tulane University Box Coring Study Conducted on Continental Shelf (Allison et al., 2007)

of water. The West Bay x-radiographs were sampled in $7 \mathrm{ft}(2 \mathrm{~m})$ of water or less. It is conceivable that friction introduced from sub-aerial and shallow features such as marshes, remnant ridges, and spoil banks slowed storm surge backflows enough to induce deposition of sediments possibly eroded from these features. This is especially true in sites closest to bay edges and is supported by the ${ }^{7}$ Be distribution patterns seen for fall 2005 in Figure 4-5. The sites with the largest detected ${ }^{7} \mathrm{Be}$ inventories are found on the northern and western edges of the bay which likely received the highest backflow velocities after the storm.

\subsection{Comparison with Other Diversions and Deltas}

Because this study was conducted within the first 2.5 years of the project life for the West 
Bay sediment diversion, it provides a prognosis of initial performance only. To project what we have learned about the environmental parameters which affect land-building rates into the future, it is necessary to compare the West Bay project to other diversions and land-building deltas in the Lower Mississippi River (LMR) Basin. During the past 100 years, the USACE New Orleans District has designed and constructed numerous diversions in an effort to regulate the diversion of water and sediment to distributaries in the LMR Basin. Table 4-8 summarizes diversions on the LMR Basin below Natchez, Louisiana, with a minimum capacity of 5,000 $\mathrm{ft}^{3} / \mathrm{s}\left(140 \mathrm{~m}^{3} / \mathrm{s}\right)$ (CH2M Hill et al., 2004).

Of the diversions listed in Table 4-8, only Bonnet Carre, Caernarvon, Davis Pond, and West Bay discharge into coastal waters and wetlands. Each of the diversions which discharge into coastal zone provide freshwater, nutrient, and sediment benefits to coastal wetlands (Snedden et al., 2006; Wheelock, 2003; Lane et al., 2001; Swenson et al., 2006). However, only the West Bay diversion was specifically designed to create new wetlands. Therefore, it is more appropriate to compare the land-building potential of the West Bay diversion to the Wax Lake and Atchafalaya Deltas which are shown in Figure 4-9.

The Wax Lake Outlet was dredged in 1942 by the USACE as a means of reducing flood elevations on the Lower Atchafalaya River (LAR) at Morgan City (CH2M Hill et al., 2004). Sediment-laden discharges from the outlet and the mouth of the Atchafalaya River began forming mudflat accretion along the eastern chenier plain in the 1950's, dramatic shoaling near both outlets in the 1960's and 70's, and subaerial delta growth after the flood of 1973 (Roberts, 1997). These events marked the transition of the Atchafalaya delta system from a lacustrine delta to a bayhead delta (Fig. 1-3). 
Table 4 - 8. Summary of Diversions on the Lower Mississippi River below Natchez

\begin{tabular}{|c|c|c|c|c|c|}
\hline Diversion & $\begin{array}{c}\text { River Mile } \\
\text { (Above } \\
\text { Head of } \\
\text { Passes) } \\
\end{array}$ & $\begin{array}{c}\text { Description } \\
\text { of Control } \\
\text { Structure } \\
\end{array}$ & Purpose & $\begin{array}{c}\text { Maximum } \\
\text { Design } \\
\text { Discharge } \\
\text { (cfs) }\end{array}$ & $\begin{array}{c}\text { Date } \\
\text { Completed }\end{array}$ \\
\hline \multicolumn{6}{|c|}{ 1. Old River Control Complex } \\
\hline Low-Sill & 314.5 & $\begin{array}{l}\text { Controlled } \\
\text { Spillway }\end{array}$ & $\begin{array}{l}\text { Maintain Distribution } \\
\text { of Flow and Sediment }\end{array}$ & 500,000 & 1962 \\
\hline Overbank & 314.5 & $\begin{array}{l}\text { Controlled } \\
\text { Spillway }\end{array}$ & Flood Control & 150,000 & 1962 \\
\hline Auxiliary & 312 & $\begin{array}{l}\text { Controlled } \\
\text { Spillway }\end{array}$ & $\begin{array}{l}\text { Maintain Distribution } \\
\text { of Flow and Sediment }\end{array}$ & 350,000 & 1986 \\
\hline Hydropower & 316.5 & $\begin{array}{l}\text { Controlled } \\
\text { Spillway }\end{array}$ & Power Generation & 170,000 & 1990 \\
\hline 2. Morganza & 285 & $\begin{array}{l}\text { Controlled } \\
\text { Spillway }\end{array}$ & Flood Control & 600,000 & 1963 \\
\hline 3. Bonnet Carre & 133 & $\begin{array}{l}\text { Controlled } \\
\text { Spillway }\end{array}$ & Flood Control & 250,000 & 1932 \\
\hline 4. Caernarvon & 85 & $\begin{array}{l}\text { Box } \\
\text { Culverts }\end{array}$ & Freshwater Diversion & 8,000 & 1991 \\
\hline 5. Davis Pond & 122 & $\begin{array}{l}\text { Box } \\
\text { Culverts }\end{array}$ & Freshwater Diversion & 10,050 & 2003 \\
\hline 6. West Bay & 4.5 & $\begin{array}{l}\text { Uncontrolled } \\
\text { Channel }\end{array}$ & Sediment Diversion & $20,000^{*}$ & 2003 \\
\hline
\end{tabular}

*Design discharge at 50\% river stage. Initial discharge is planned to be increased to $50,000 \mathrm{cfs}$.

(from CH2M Hill et al., 2004)

As with the LMR, many data sets measuring parameters such as discharge, sediment loads, bay-bottom bathymetry, and wind climate have been collected on the LAR by various governmental agencies. These data sets were compiled by CH2M Hill et al. in 2004 to create a design analog for the Wax Lake Delta for use in a reconnaissance-level evaluation of the Third Delta Conveyance Channel concept proposed by Gagliano and van Beek (1999). Table 4-9 summarizes pertinent delta building parameters from Wax Lake as compared to observations and estimations for West Bay from this study.

Table 4-9 compares West Bay to Wax Lake in terms of the sediment delivery characteristics of flows and sediment loads as well as sediment retention characteristics of water 


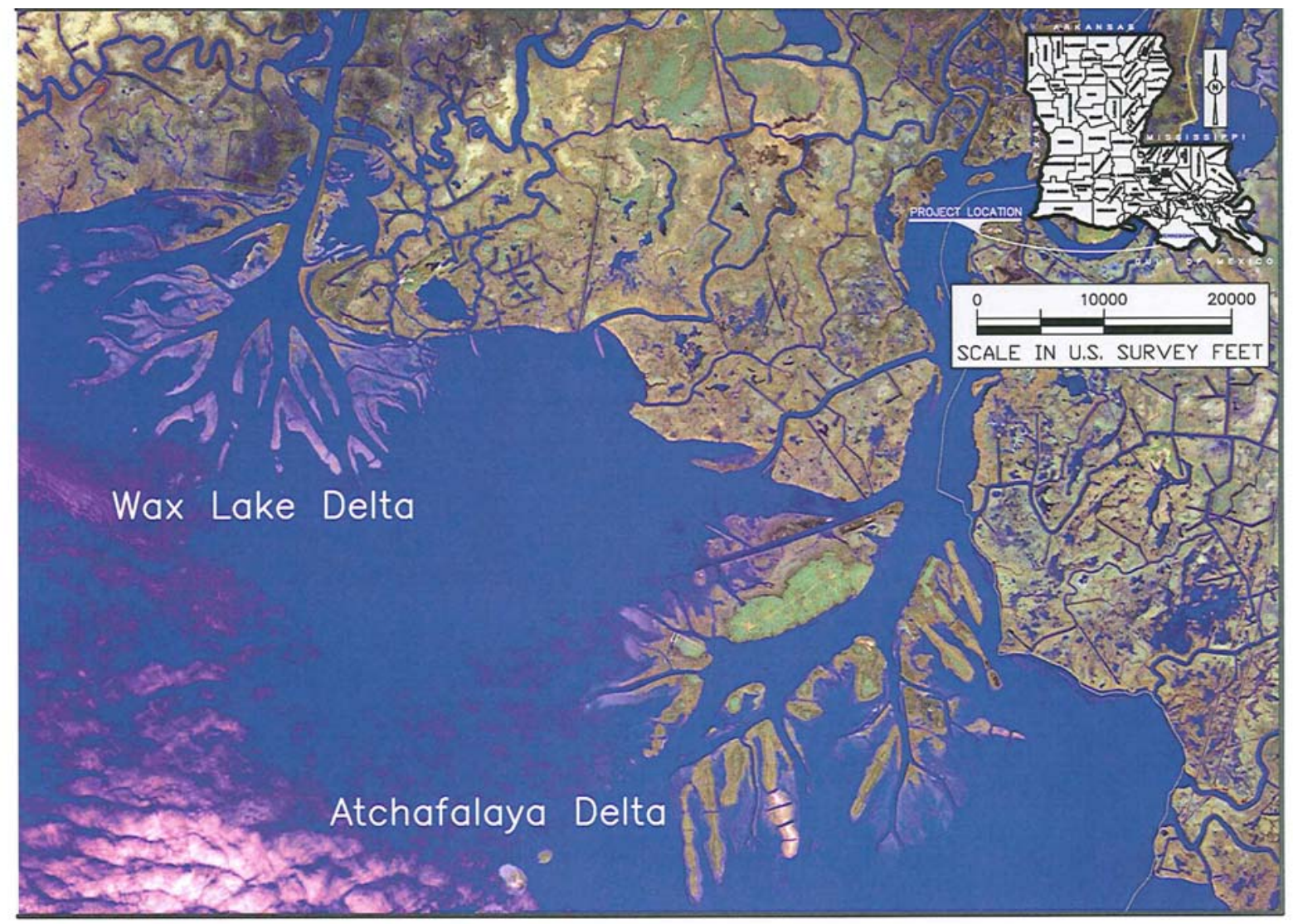

Figure 4-9. Location Map of Atchafalaya and Wax Lake Bayhead Deltas (1998 Aerial)

Table 4 - 9. Comparison of Wax Lake and West Bay Delta Building Parameters

\begin{tabular}{lccc}
\hline & $\begin{array}{c}\text { Wax Lake } \\
\text { Outlet }^{1}\end{array}$ & $\begin{array}{c}\text { West Bay } \\
\text { Diversion }^{2}\end{array}$ & $\begin{array}{c}\text { Ratio of West Bay } \\
\text { to Wax Lake }^{2}\end{array}$ \\
\hline \hline Max Flow (cfs) & 146,000 & 41,000 & 0.28 \\
Avg Flow (cfs) & 73,000 & 14,000 & 0.19 \\
Min Flow (cfs) & 30,000 & 3,300 & 0.11 \\
Avg Sediment Load (tons/year) & $28,700,000$ & $2,900,000$ & 0.10 \\
Avg Water Depth (ft) & $5-6$ & $5-6$ & 1.00 \\
Estimated Trapping Efficiency (\%) & $25-47 \%$ & $25-50 \%$ & 1.00 \\
\hline
\end{tabular}

1. From $\mathrm{CH} 2 \mathrm{M}$ Hill et al., 2004

2. Estimations from this study 
depths and sediment trapping efficiency, which encompasses factors such as wind and wave climate and receiving area configuration. In comparison, it is estimated that the West Bay Diversion could have between 10 and 28\% the sediment delivery potential of the Wax Lake Outlet while the sediment retention characteristics are approximately the same. Documented average growth rates of subaerial delta land mass (above mean low tide) in the Wax Lake Delta averaged 510 ac/year (210 ha/year) between 1972 and 1992 (Roberts and van Heerden, 1992). Multiplying this average growth rate by the range of sediment delivery ratios between West Bay and Wax Lake results in a range potential deltaic growth rates of between 51 ac/year (21 ha/year) and 143 ac/year (59 ha/year) for the West Bay Sediment Diversion Project. Dividing the project goal of creating 9,831 ac (3,978 ha) of deltaic wetlands by the upper end of this estimated range, results in a time frame of 70 years to achieve the project goal of peak delta growth. This estimate correlates with documented subdelta life cycles of 100 - 150 years (Coleman and Prior, 1982). It should be noted that this analysis is based on broad correlations between the Wax Lake Outlet and West Bay Sediment Diversion characteristics, and preliminary observations only for the West Bay diversion, which may be improved upon with future study. 


\section{CONCLUSIONS AND FUTURE CONSIDERATIONS}

If we understand the processes controlling sediment dispersal, we can better design landbuilding projects to more efficiently utilize river sediment, a precious commodity in the Mississippi Delta. Diversion hydrographs and turbidity data show strong indication that the West Bay Sediment Diversion is delivering sediment from the Mississippi River into West Bay. This sediment is likely accompanied by sediment from other fluvial sources such as Grand Pass and smaller hydrologic connections to Mississippi River. This is seen in satellite images which also suggest that major portions of the fine sediment delivered bypass the bay which is open to Gulf of Mexico. Analysis of ${ }^{7}$ Be activities and inventories and x-radiograph images of sediment profiles present evidence of episodic deposition within West Bay with potential for long term retention. This was not confirmed by pre- and post-diversion bathymetric data of the bay bottom which showed evidence of large amounts sediment loss and shoreline erosion due to Hurricane Katrina.

The data collected as part of this study have provided an initial measure diversion performance. It is clear that the initial stages of subdelta formation have begun through diversion scour, increased flow capacity, formation a distributary channel through the bay, and delivery of fine sediments to a depositional front. Some factors working against rapid subaerial land development are coastal wind and wave attack, bay bottom depths, and a lack of estuarine enclosure. Hurricane Katrina produced major unanticipated changes, erasing the initial depositional record of the diversion replacing it with bedded deposits left by receding flood waters. Documented historical subdeltas have experienced similar conditions over time. Project development may continue following a typical subdelta growth curve, meaning peak development of deltaic wetlands could be decades away. Therefore, future planning for 
diversions should consider coastal processes that reduce sediment retention. Engineering strategies should place as much focus on receiving area configuration and trapping efficiency as sediment delivery in order to maximize sediment retention.

The results of this study should be used as an initial baseline for future performance monitoring efforts. These include continued diversion flow measurements; vegetation and elevation surveys in 2008, 2013, 2018, and 2023; and analysis of aerial photography for land/water ratios. Additionally, a sediment transport model is being developed using the flow and turbidity data collected as part of this study. Currently, no further collection of ${ }^{7} \mathrm{Be}$, turbidity, and velocity data is planned. However, future collection and analyses of these parameters along with detailed satellite imagery analysis could add to the findings presented herein. Eventually, a life cycle model for diversion evolution could be developed to serve as a powerful restoration planning tool. 


\section{REFERENCES}

American Society of Civil Engineers (ASCE), 1998. Hydrographic Surveying. Technical Engineering and Design Guides as Adapted from the U.S. Army Corps of Engineers. ASCE Publications, no. 54, 418 p.

American Society of Civil Engineers (ASCE), Edited by Vanoli, V.A., 2006. Sedimentation Engineering. ASCE Manuals and Reports on Engineering Practice. ASCE Publications, no. 25, $328 \mathrm{p}$.

Allison, M.A., G.C. Kineke, E.S. Gordon, and M.A. Goni, 2000. Development and reworking of a seasonal flood deposit on the inner continental shelf off the Atchafalaya River. Continental Shelf Research, v. 20, p. 2267-2294.

Allison, M.A. T.M. Dellapenna, M.A. Goni, and A. Sheremet, 2007. Impact of Hurricanes Katrina and Lili on the inner shelf of the Mississippi Atchafalaya Delta. Proceedings of the Sixth International Symposium on Coastal Engineering and Science of Coastal Sediment Processes, v.2, p. 882-887.

Baskaran, M., 1995. A search for the seasonal variability on the depositional fluxes of Be-7 and Pb-210. Journal of Geophysical Research. 100 (D2): 2833-2840.

Baskaran, M., C.H. Coleman, and P.H. Santschi, 1993. Atmospheric depositional fluxes of 'Be and ${ }^{210} \mathrm{~Pb}$ at Galveston and College Station, Texas. Journal of Geophysical Research. 98(11):20,555-20,571.

Baskaran, M. and P.H. Santschi, 1993. The role of particles and colloids in the transport of radionuclides in coastal environments of Texas. Marine Chemistry, V. 43, p. 95-114.

Baskaran, M., M. Ravichandran, and T. S. Bianchi, 1997. Cycling of ${ }^{7} \mathrm{Be}$ and ${ }^{210} \mathrm{~Pb}$ in a High DOC, Shallow, Turbid Estuary of South-east Texas. Estuarine, Coastal and Shelf Science, v. 45, p. 165-176.

Bentley, Samuel J., 2003. Wave-Current Dispersal of Fine-Grained Fluvial Sediments Across Continental Shelves: the Significance of Hyperpycnal Plumes: In E.D. Scott, A.H. Bouma and W.R. Bryant (Eds.) Siltstones, Mudstones and Shales: Depositional Processes and Characteristics. Society for Sedimentary Geology/Gulf Coast Association of Geological Societies Joint Publication, p. 35-48.

Booth, J. G., R. L. Miller, B. A. McKee, and R. A. Leathers, 2000. Wind-induced bottom sediment resuspension in a microtidal coastal environment. Continental Shelf Research, v. 20, p. 785-806.

Boyer, M. E., J. O. Harris and R. E. Turner, 1997. Constructed crevasses and land gain in the Mississippi River delta. Restoration Ecology, v. 5, no. 1, p. 85-92. 
Breed, C.B. and G.L. Hosmer, 1908. The Principles and Practice of Surveying, Volume I. Elementary Surveying, Third Edition. John Wiley and Sons. 552 p.

Canuel, E.A., C.S. Martens and L.K. Benninger, 1990. Seasonal variations in 7 Be activity in the sediment of Cape Lookout Bight, North Carolina. Geochimica et Cosmochimica Acta. v. 54, p. 237-245.

Chauhan, O.S., A.S. Rajawat, Y. Pradhan, J. Suneethi, and S.R. Nayak, 2005. Weekly observations on dispersal and sink pathways of the terrigenous flux of the GangaBrahmaputra in the Bay of Bengal during NE monsoon. Deep Sea Research Part II: Tropical Studies in Oceanography, v. 52, issues 14-15, p. 2018-2030.

CH2M Hill, Mussetter Engineering, Inc., Mobile Boundary Hydraulics, PPLC, and Eustis Engineering Company, Inc., 2004. Phase 1 Reconnaissance-level Evaluation of the Third Delta Conveyance Channel Project. Final Report Prepared for the Louisiana Department of Natural Resources.

Coleman, J. M. and Gagliano, S.M., 1964. Cyclic Sedimentation in the Mississipp River deltaic plain. Transactions - Gulf Coast Association of Geological Societies, v. XIV, p. 67-80.

Coleman, J.M. and D.B. Prior, 1982. Deltaic Sand Bodies: A 1980 Short Course. Education Course Note Series \#15, 171 p. Third Printing, September 1982. American Association of Petroleum Geologists.

Coleman, J.M., 1988. Dynamic changes and processes in the Mississippi River delta. Geological Society of America Bulletin, v. 100, p. 999-1015.

Coleman, J.M., Boyd Professor, Louisiana State University, Coastal Studies Institute, 2006. Personal communication with Mitch Andrus and approval to use unpublished data on November 27, 2006.

Collis, H.A., 2006. Application of short-term sediment dynamics and particle-bound phosphorus fractionation methods (SEDEX) to estimate the benthic nutrient loading potential in Upper Newport Estuary, California. Louisiana State University MS Thesis, 61 p.

Dibb, J.E. and L.D. Meeker. 1994. Estimation of stratospheric input to the Arctic troposphere: Be-7 and Be-10 in aerosols at Alert, Canada. Journal of Geophysical Research, v. 99, p. 12855-12864.

Dyer, K.R., 1995. Sediment transport processes in estuaries. Perillo, G.M.E., Geomorphology and Sedimentology of Estuaries, Elsevier Science B. V. Amsterdam, p. 423-449.

Feng, H., J.K. Cochran, and D.J. Hirschberg, 1999. ${ }^{234} \mathrm{Th}$ and ${ }^{7} \mathrm{Be}$ as tracers for the transport and dynamics of suspended particles in a partially mixed estuary. Geochimica et Cosmochimica Acta, v. 63, no. 17, p. 2487-2505. 
Fisk, Harold N., 1951. Mississippi River Valley Geology Relation to River Regime. Transactions, American Society of Civil Engineers 1951, p. 667-682.

Friedrichs, C. T., L. D. Wright, D. A. Hepworth, and S.C. Kim, 2000. Bottom-boundary layer processes associated with fine sediment accumulation in coastal seas and bays. Continental Shelf Research, v. 20, p. 807-841.

Gagliano, S.M., and J.L. van Beek, 1999. The Third Delta Conveyance Channel Project. Proposed Mississippi River Diversion Channel and Subdelta Building in the BaratariaTerrebonne Area of Coastal Louisiana. Section 6 in Appendix B of Coast 2050.

Galler, J.J. and M.A. Allison, 2007. Estuarine Controls on Fine-Grained Sediment Storage in the Lower Mississippi and Atchafalaya Rivers. Resubmitted to GSA Bulletin as B26060, January 2007.

Hunt, J.N., 1979. Direct solution of wave dispersion equation. J. Waterways, Ports, Coastal Ocean Div., ASCE 105(WW4):457-459.

Keown, M.P., E.A. Dardeau, Jr., and E.M. Causey, 1981. Characterization of the suspended sediment regime and be material gradation of the Mississippi River basin. U.S. Army Corps of Engineers, Lower Mississippi Valley Div., Potamology Program (P-1), 2 volumes.

Keown, M.P., E.A. Dardeau, Jr., and E.M. Causey, 1986. Historic trends in the sediment flow regime of the Mississippi River. Water Resources Res., v. 22, p. 1555-1564.

Kesel, R. H., 1988. The Decline in the Suspended Load of the Lower Mississippi River and its Influence on Adjacent Wetlands. Environ. Geol. Water Sci., v. 11, no. 3, 271-281.

Lane, R.R., J.W. Day, Jr., G.P. Kemp, and D.K. Demcheck, 2001. The 1994 experimental opening of the bonnet Carre Spillway to divert Mississippi River water into Lake Pontchartrain, Louisiana. Ecological Engineering, v. 17, p. 411-422.

Leeder, M.R., 1982. Sedimentology: Process and Product. G. Allen and Unwin, xiv, 344 p.

Louisiana Department of Natural Resources, 2003, Monitoring Plan, Project No. MR-03, West Bay Sediment Diversion. Date: August 21, 2003.

Manning, A.J., Bass, S.J., and Dyer, K.R., 2006. Floc properties in the turbidity maximum of a mesotidal estuary during neap and spring tidal conditions. Marine Geology, v. 235, p. 193 $-211$.

Milliman, J.D. and R.H. Meade, 1983. World-wide delivery of river sediment to the oceans. Journal of Geology, v. 91, p. 1-21. 
Mossa, J., 1996. Sediment dynamics in the lowermost Mississippi River. Engineering Geology, v. 45, p. 457-479.

Nittrouer, C.A., DeMaster, D.J., McKee, B.A., Cutshall, N.H., Larsen, I.L., 1984. The effect of sediment mixing on $\mathrm{Pb}-210$ accumulation rates for the Washington continental shelf. Marine Geology, v. 54, p. 201-221.

Olsen, C.R., I.L. Larsen, P.D. Lowrey, and N.H. Cutshall. 1986. Geochemistry and deposition of ${ }^{\prime}$ Be in river, estuarine and coastal waters. Journal of Geophysical Research, 91(C1): 896908.

Palinkas, C. M., C. A. Nittrouer, R. A. Wheatcroft, and L. Langone, 2005. The use of ${ }^{7}$ Be to identify event and seasonal sedimentation near the Po River delta, Adriatic Sea. Marine Geology, v. 222-223, p. 95-112.

Penland S, and Boyd R. 1981. Shoreline changes on the Louisiana barrier coast. IEEE Oceans, v. 81, pp. 209-219.

Rehfeld, S. and M. Heimann. 1995. Three dimensional atmospheric transport simulation of the radioactive tracers ${ }^{210} \mathrm{~Pb},{ }^{7} \mathrm{Be},{ }^{10} \mathrm{Be}$, and ${ }^{90} \mathrm{Sr}$. Journal of Geophysical Research, 100(D12): 26141-16161.

Roberson, J.A. and C.T. Crowe, 1993. Engineering Fluid Mechanics, Fifth Edition. Houghton Mifflin Company.

Roberts, H.H. and I.L. van Heerden, 1992. Atchafalaya-Wax Lake delta complex: The new Mississippi River delta lobe. Annual Coastal Studies Institute Industrial Associates Research Program, Research Report \#1, 45 p.

Roberts, H.H., 1997. Dynamic Changes of the Holocene Mississippi River Delta Plain: The Delta Cycle. Journal of Coastal Research, v. 13, no. 3, p. 605-627.

Rotondo, K.A., and Bentley, S.J., 2003. Deposition and resuspension of fluid muds on the western Louisiana inner continental shelf: Gulf Coast Association of Geological Societies Transactions, v. 53, p. 722-731.

Rotondo, K.A., 2004. Transport and deposition of fluid mud event layers along the western Louisiana inner shelf. Louisiana State University MS Thesis, 83 p.

Sallenger, A., C.W. Wright., and J. Lillycrop, 2007. Coastal-change impacts during Hurricane Katrina: An Overview. Proceedings of the Sixth International Symposium on Coastal Engineering and Science of Coastal Sediment Processes, v.2, p. 888-896.

Schoklitsch, Armin. 1937. Hydraulic Structures; a text and handbook. The American Society of Mechanical Engineers. New York, New York. 
Scruton, P.C., 1960. Delta building and the deltaic sequence. In: F.P. Shepard et al., eds., Recent Sediments, Northwest Gulf of Mexico, p. 82-102: Tulsa, Okla., Am. Assoc. Petroleum Geologists.

Snedden, G. A., J. E. Cable, C. Swarzenski, and E. Swenson, 2006. Sediment discharge into a subsiding Louisiana deltaic estuary through a Mississippi River diversion. Estuarine, Coastal and Shelf Science, doi:10.1016/j.ecss.2006.06.035.

Sommerfield, C.K., Nittrouer, C.A., and Alexander, C.R., 1999. ${ }^{7}$ Be as a tracer of flood sedimentation on the northern California margin. Continental Shelf Research v. 19, p. 335361.

Sternberg, R.W., 1972. Predicting Initial Motion and Bedload Transport of Sediment Particles in the Shallow Marine Environment. In: Swift, Duane, and Pilkey, eds., Shelf Sediment Transport: Process and Pattern. Stroudsburg, PA: Dowden, Hutchinson, and Ross, Inc., p. 61-82.

Swenson, E.M., Cable, J.E., Fry B., Justic, D., Das A., Snedden, G., and Swarzenski, C., 2006. Estuarine flushing times influenced by freshwater diversions. In: Sing, V.P. and $\mathrm{Xu}$, Y.J., eds., Coastal Hydrology and Processes, ch. 33, p. 403 - 412: Highlands Ranch, CO, Water Resources Publications, LLC.

U.S. Army Corps of Engineers, Coastal Engineering Research Center, 1984. Shore Protection Manual. Vol. I., Fourth Edition, Second Printing.

U.S. Army Corps of Engineers, 2001. Coastal Engineering Manual. EM 1110-2-1100 (Part II). Meteorology and Wave Climate.

U.S. Army Corps of Engineers, New Orleans District. October 2001. Environmental Impact Statement West Bay Sediment Diversion, Louisiana.

U.S. Army Corps of Engineers, 2003. West Bay Sediment Diversion Initial Construction Plans. 20,000 cfs Diversion and Anchorage Area. Plaquemines Parish, LA.

U. S. Army Corps of Engineers. 2004. Louisiana Coastal Area (LCA) Ecosystem Restoration Study, Appendix D - Louisiana Gulf Shoreline Restoration Report.

U.S. Army Corps of Engineers, 2006. Personal communication between Mitch Andrus and Greg Miller, USACE Project Manager, and approval to use unpublished flow data from the Mississippi River and West Bay Diversion on November 30, 2006.

van Rijn, L.C, 1984. Sediment Transport Part II. Suspended Load Transport. Journal of Hydraulic Engineering, ASCE, v. 110, p. 1613-1641.

Vogler, S., M. Jung and A. Mangini. 1996. Scavenging of ${ }^{234} \mathrm{Th}$ and ${ }^{2}$ Be in Lake Constance. Limnology and Oceanography, 41(7):1384-1393. 
Walker, N.D., 1996. Satellite Assessment of Mississippi River Plume Variability: Causes and Predictability, Remote Sens. Environ. v. 58, p. 21-35.

Walker, N.D., W.J. Wiseman Jr., L.J. Rouse Jr., and A. Babin, 2005. Effects of River Discharge, Wind Stress, and Slope Eddies on Circulation and the Satellite-Observed Structure of the Mississippi River Plume. Journal of Coastal Research, v. 26, no. 6, p. 1228-1244.

Wheelock, K., 2003. Pulsed River Flooding Effects on Sediment Deposition in Breton Sound Estuary, Louisiana. Louisiana State University MS Thesis, 80 p.

Wright, L.D., 1989. Benthic Boundary Layers of Estuarine and Coastal Environments. Aquatic Sciences, vol. I., issue 1, p. 75-95.

Wright, L.D., 1995. Morphodynamics of inner continental shelves. CRC Press, Boca Raton, 241 p.

Wright, L.D. and C.A. Nittrouer, 1995. Dispersal of River Sediments in Coastal Seas: Six Contrasting Cases. Esutaries, v. 18, no. 3, p. 494-508. 


\section{APPENDIX A \\ HISTORIC MAPS AND IMAGERY}




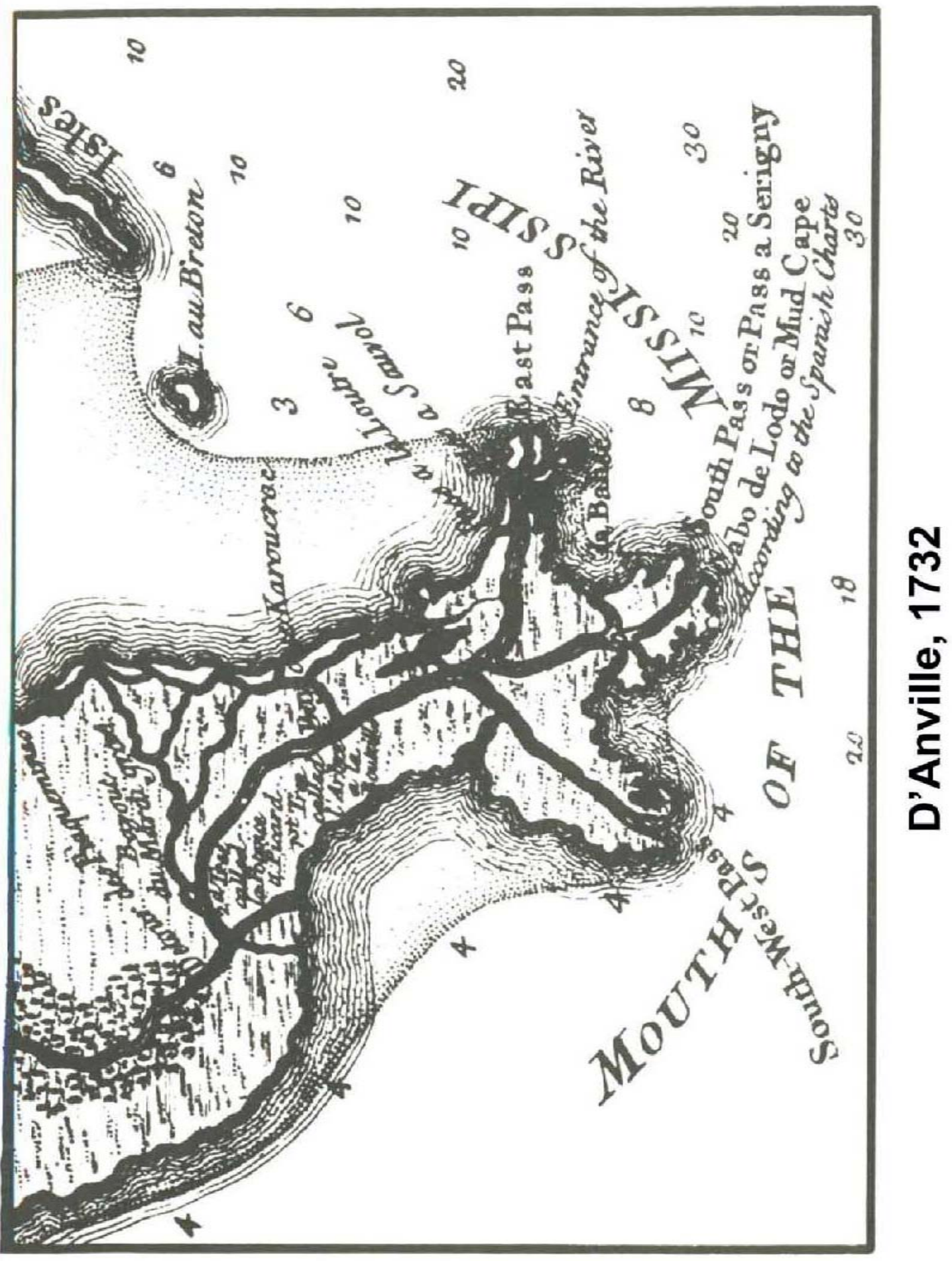




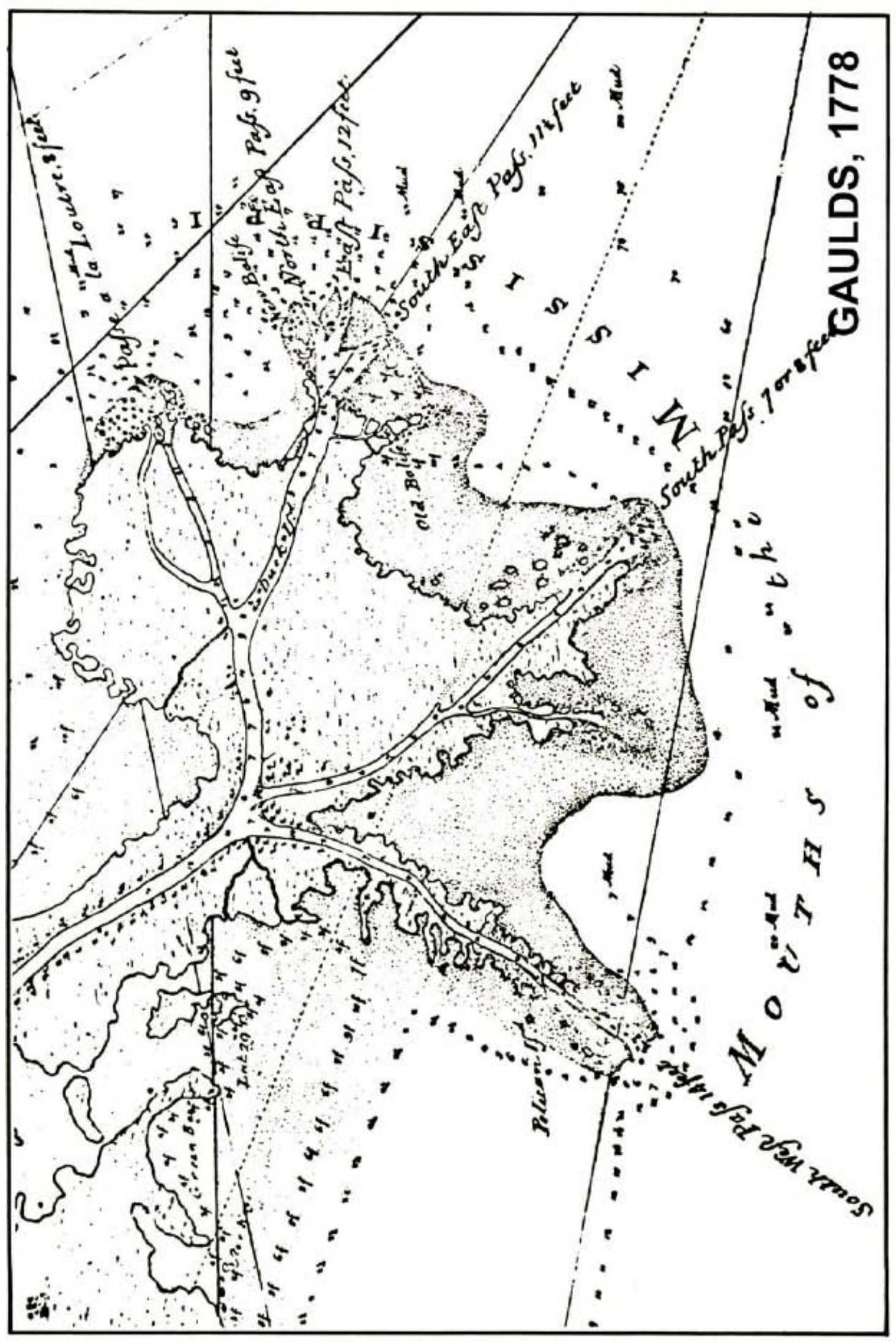




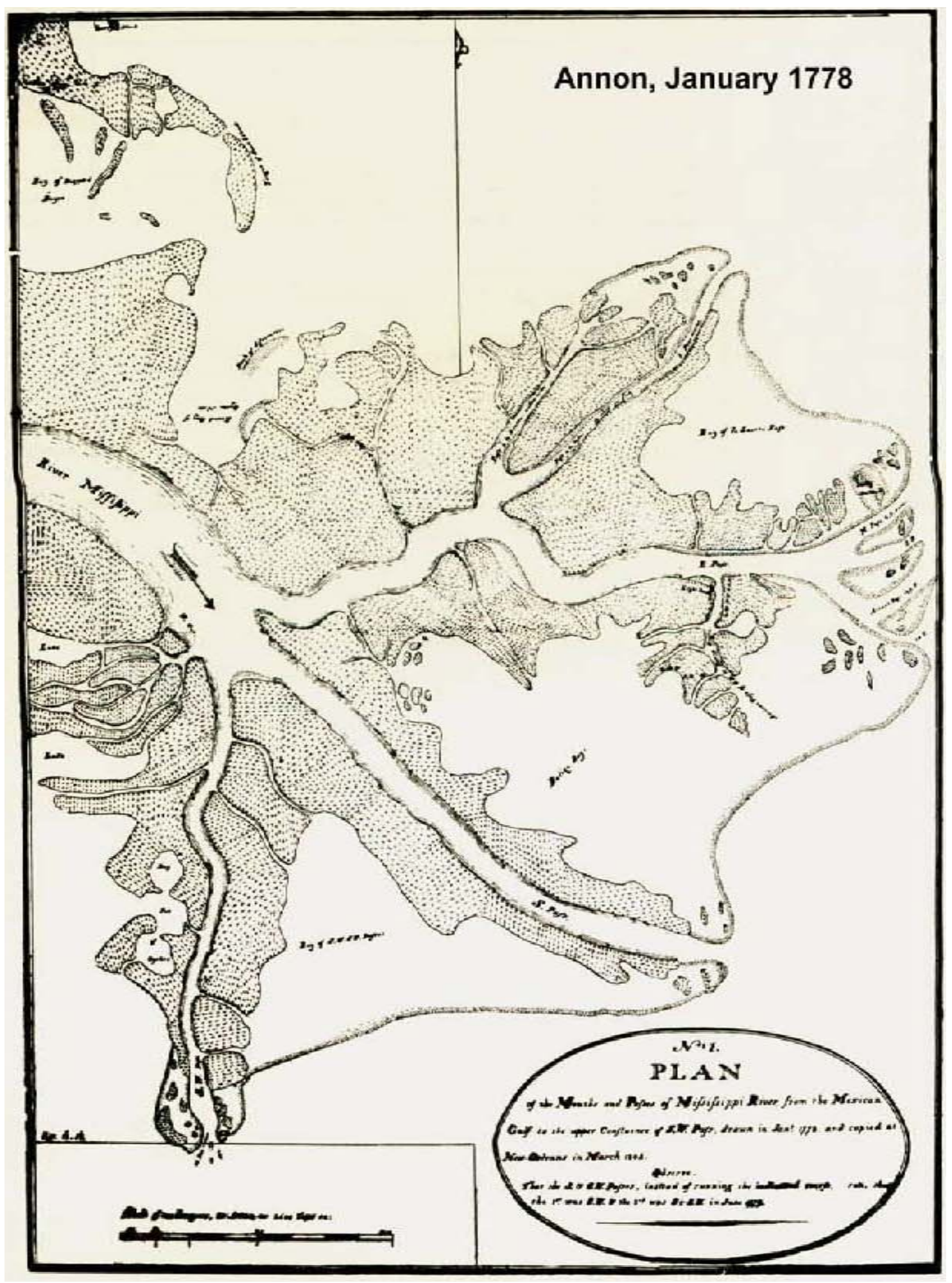




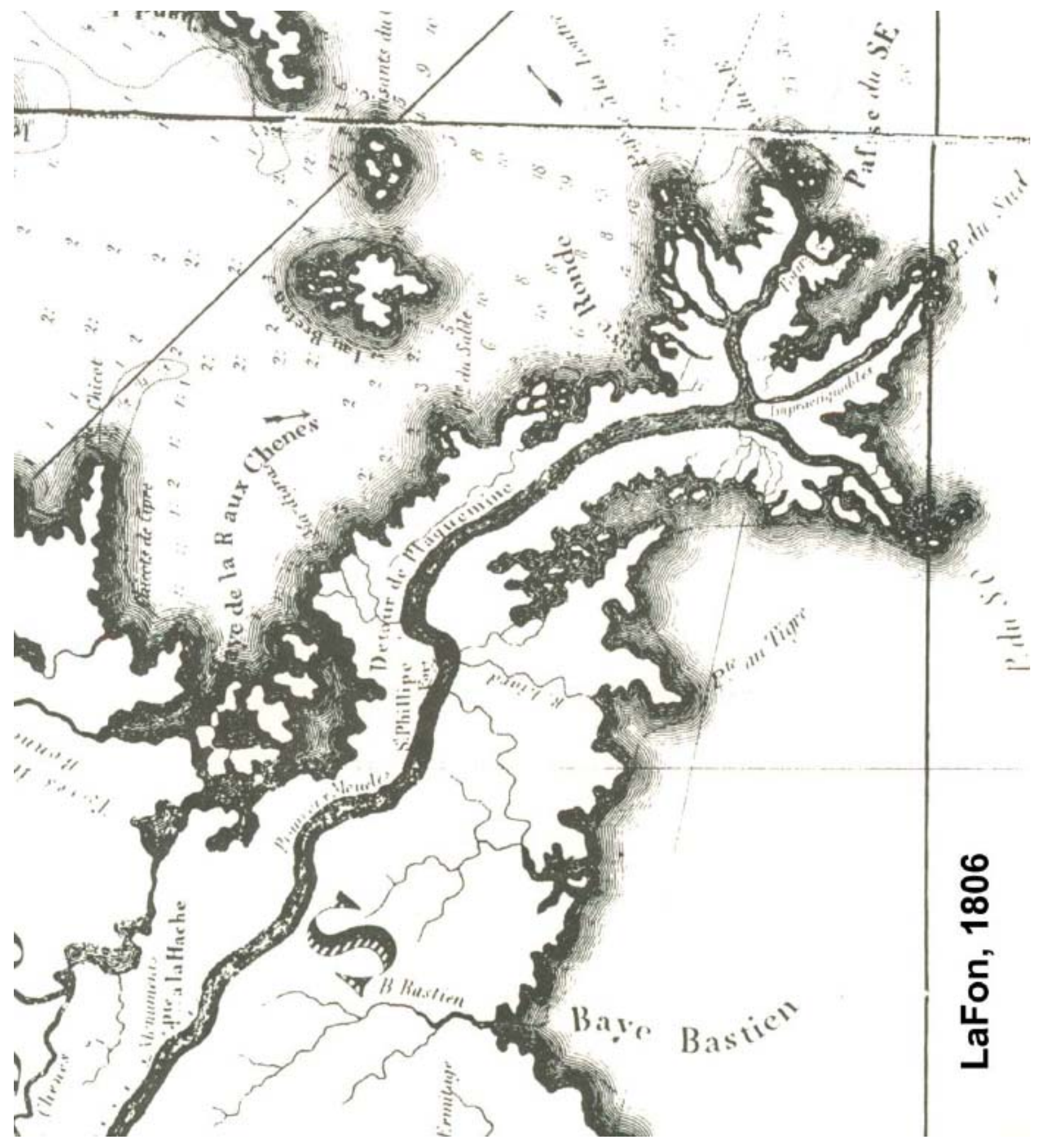




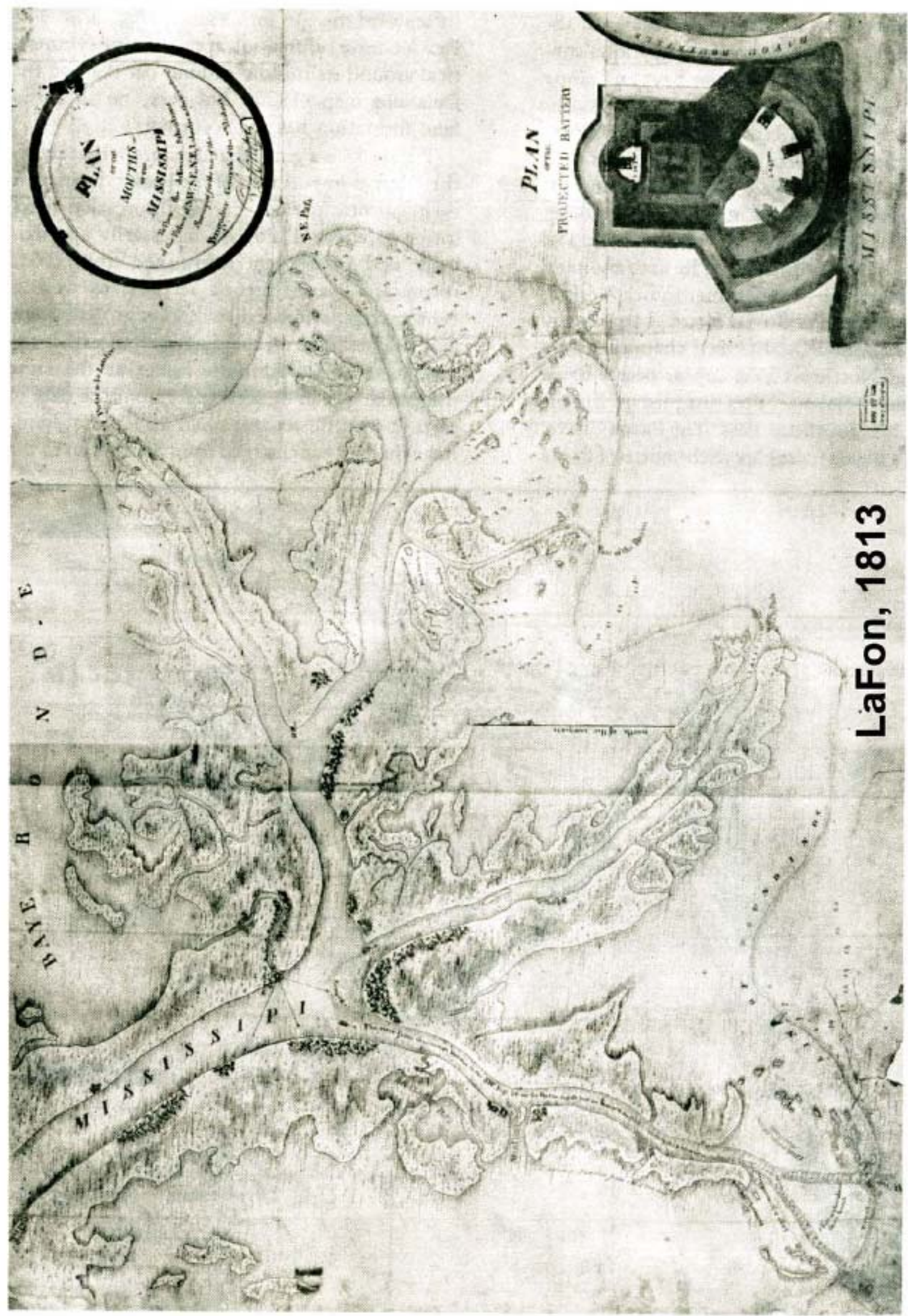




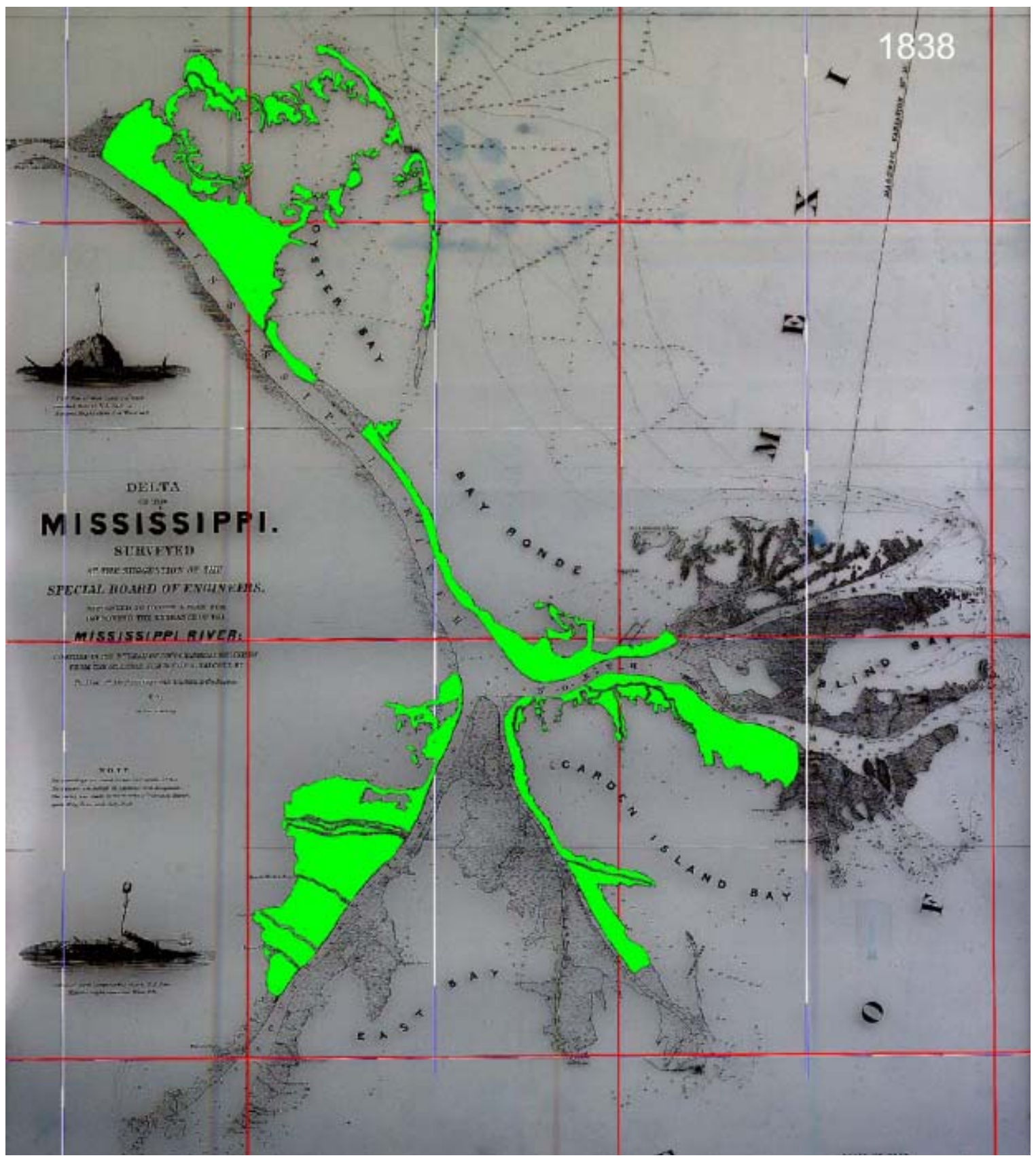




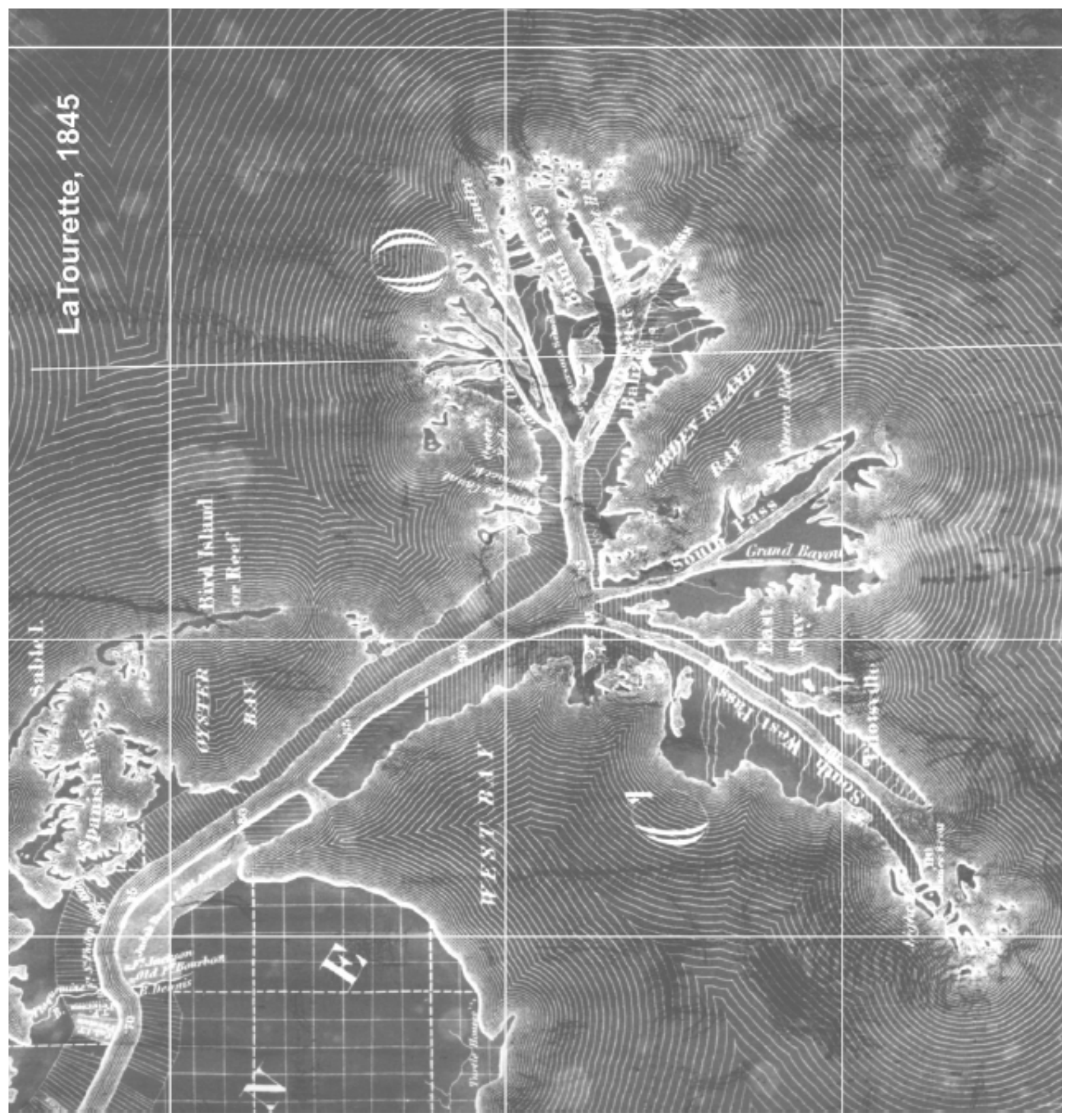




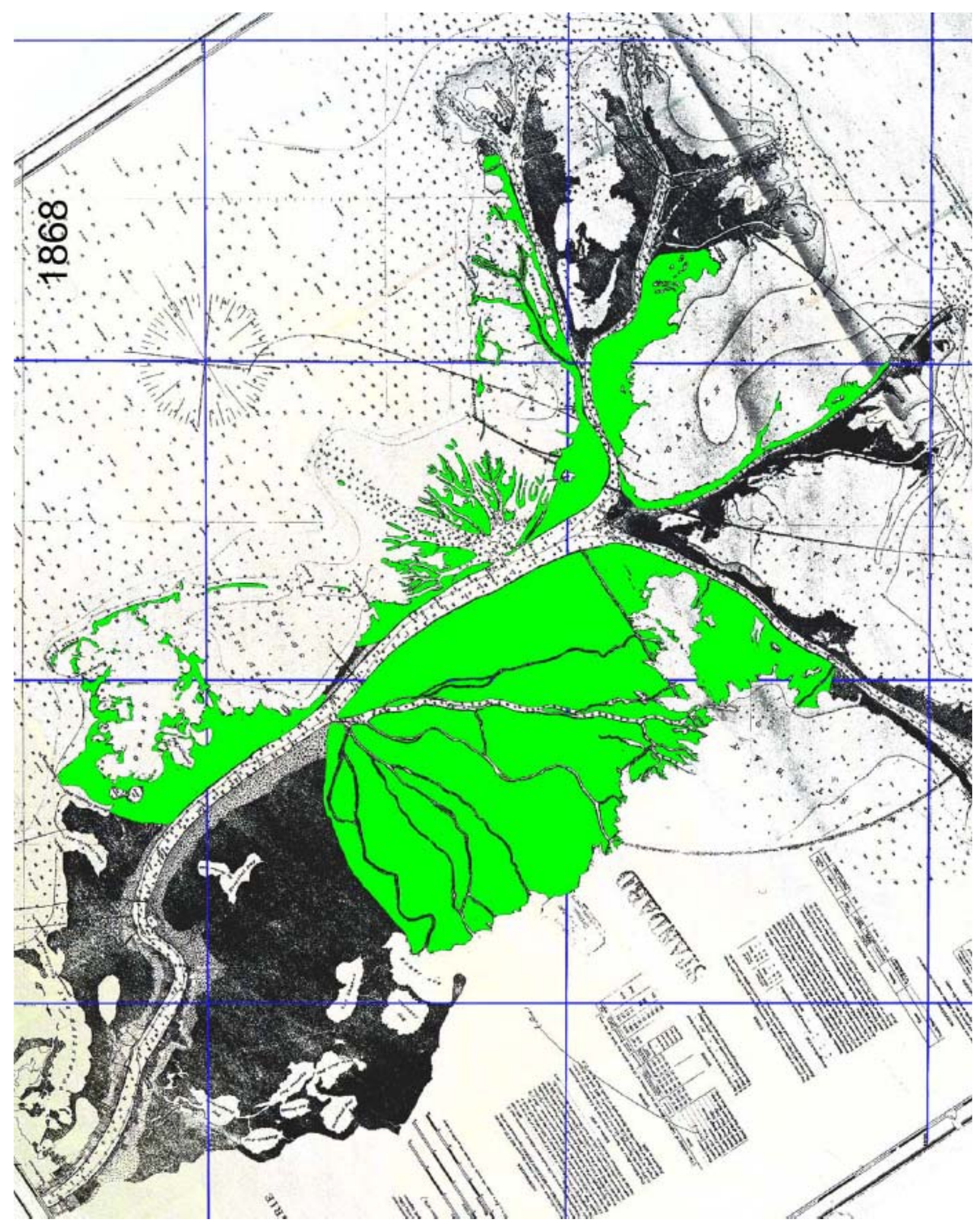




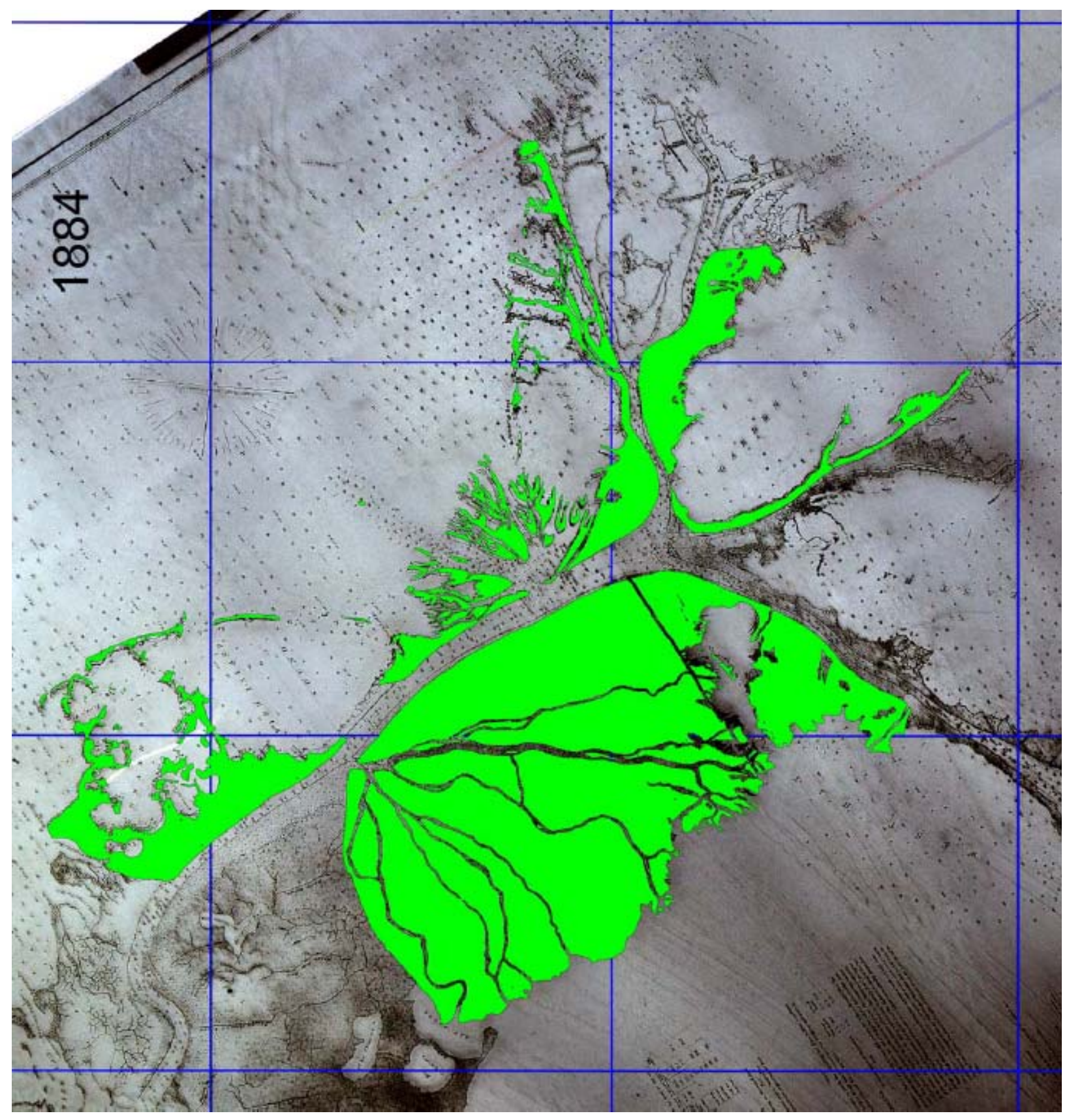




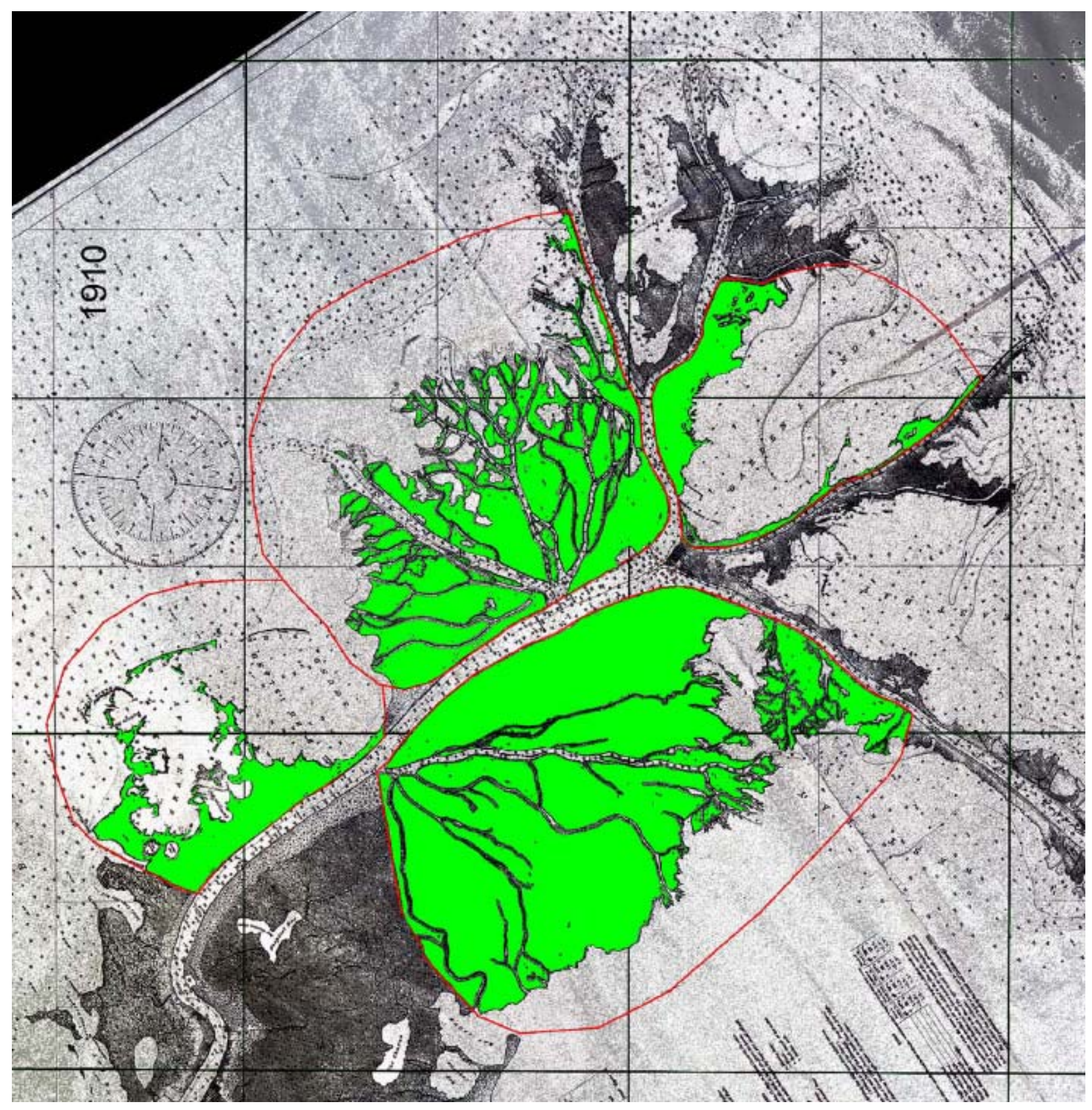




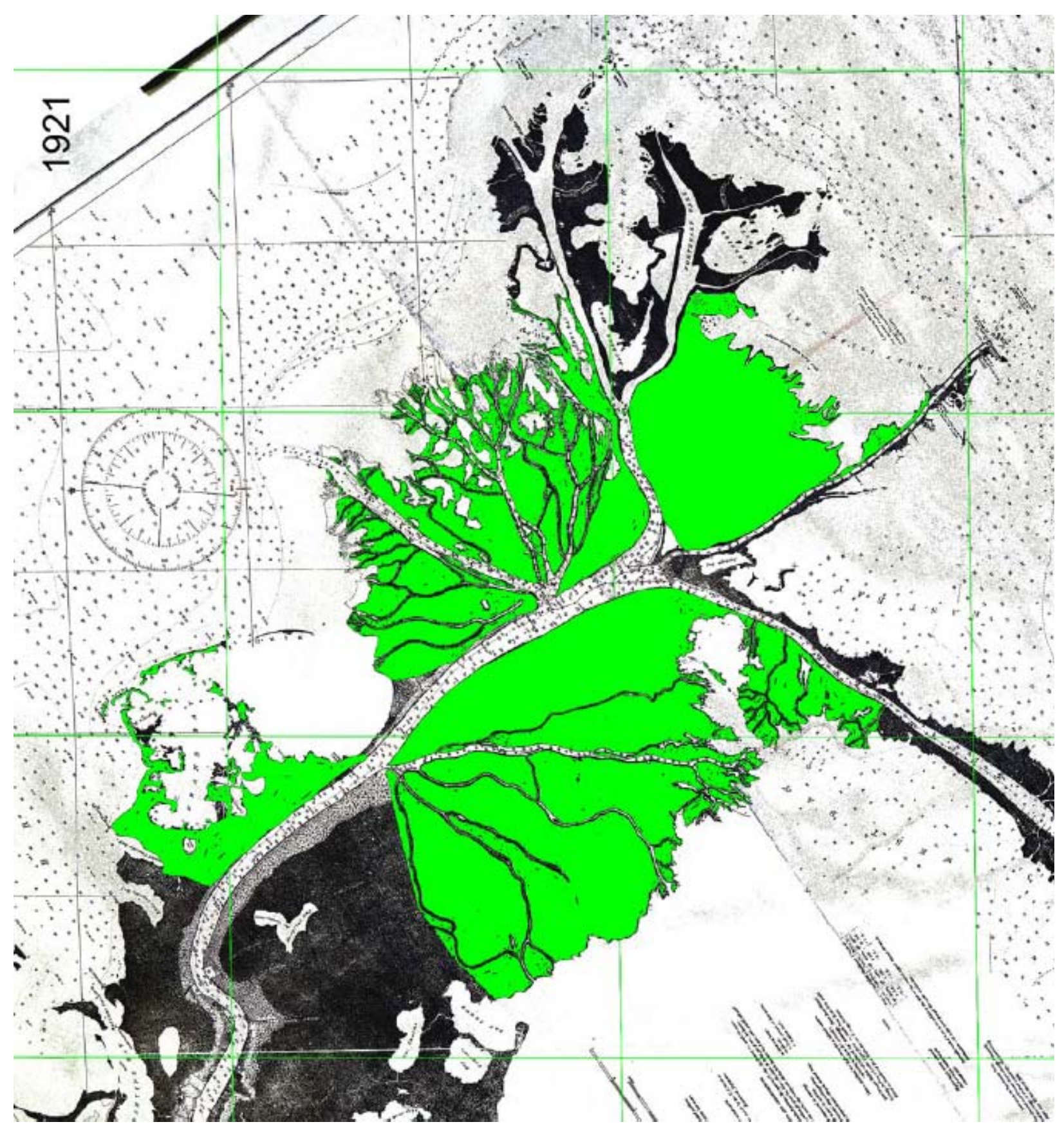




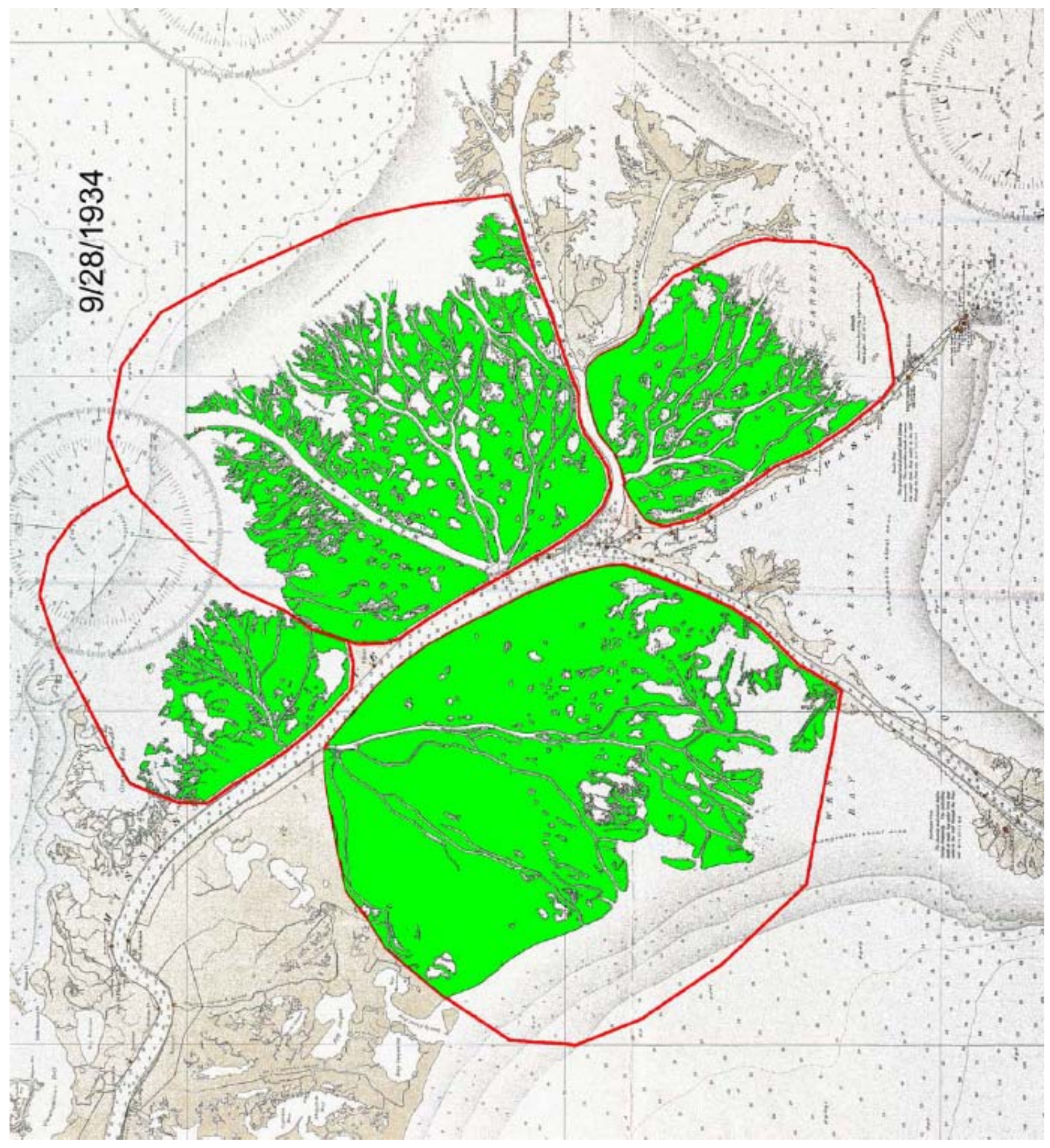




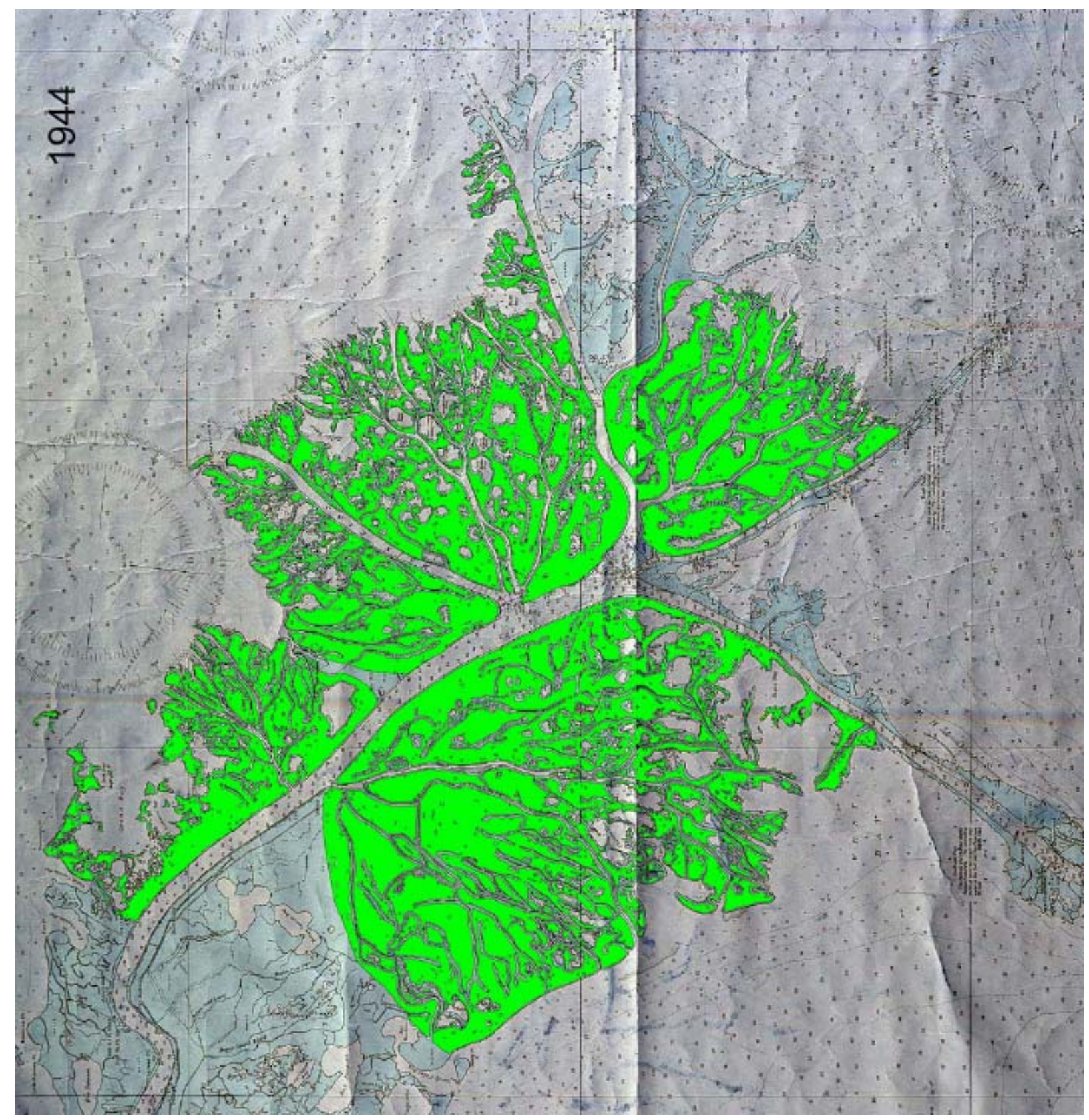




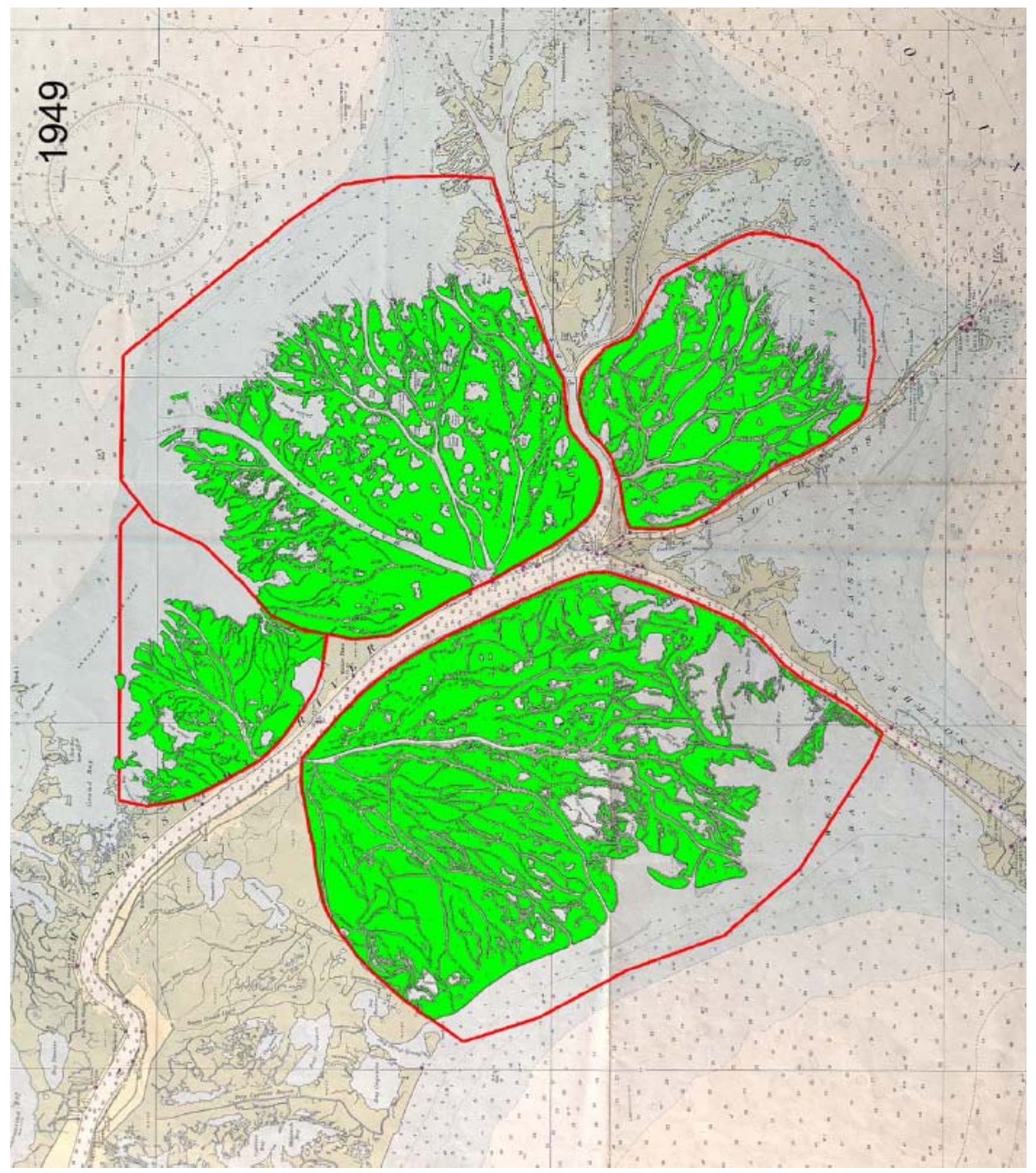




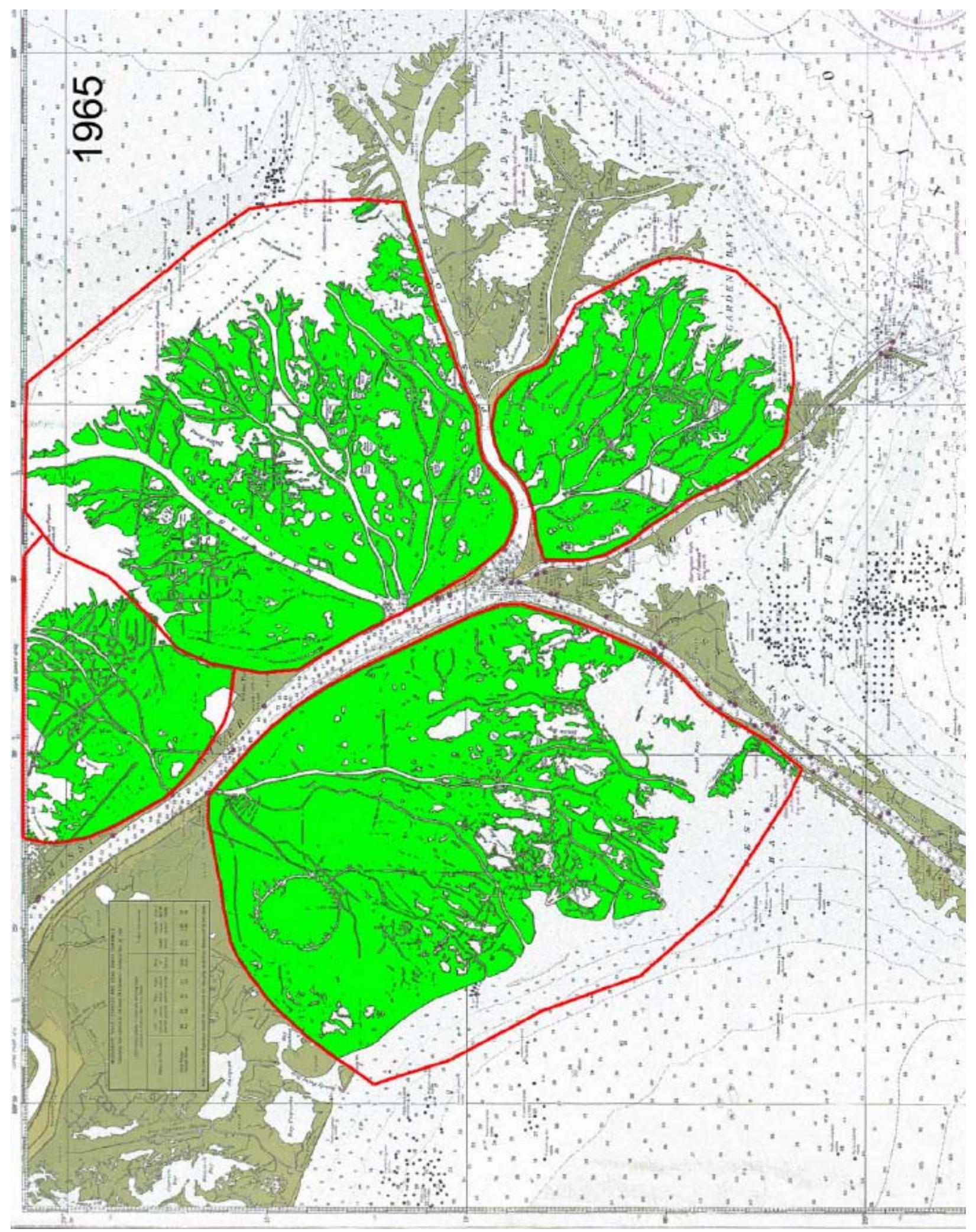




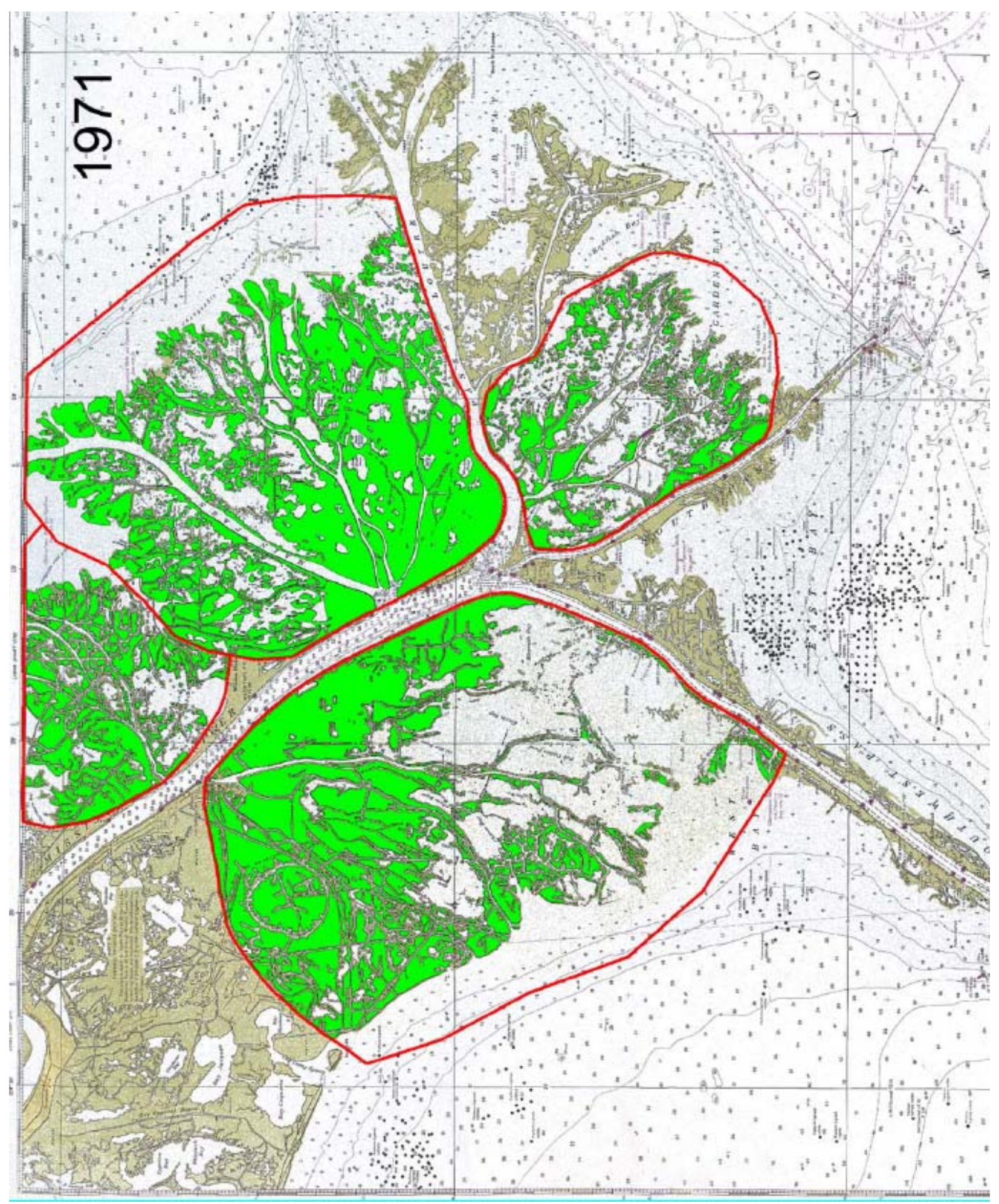




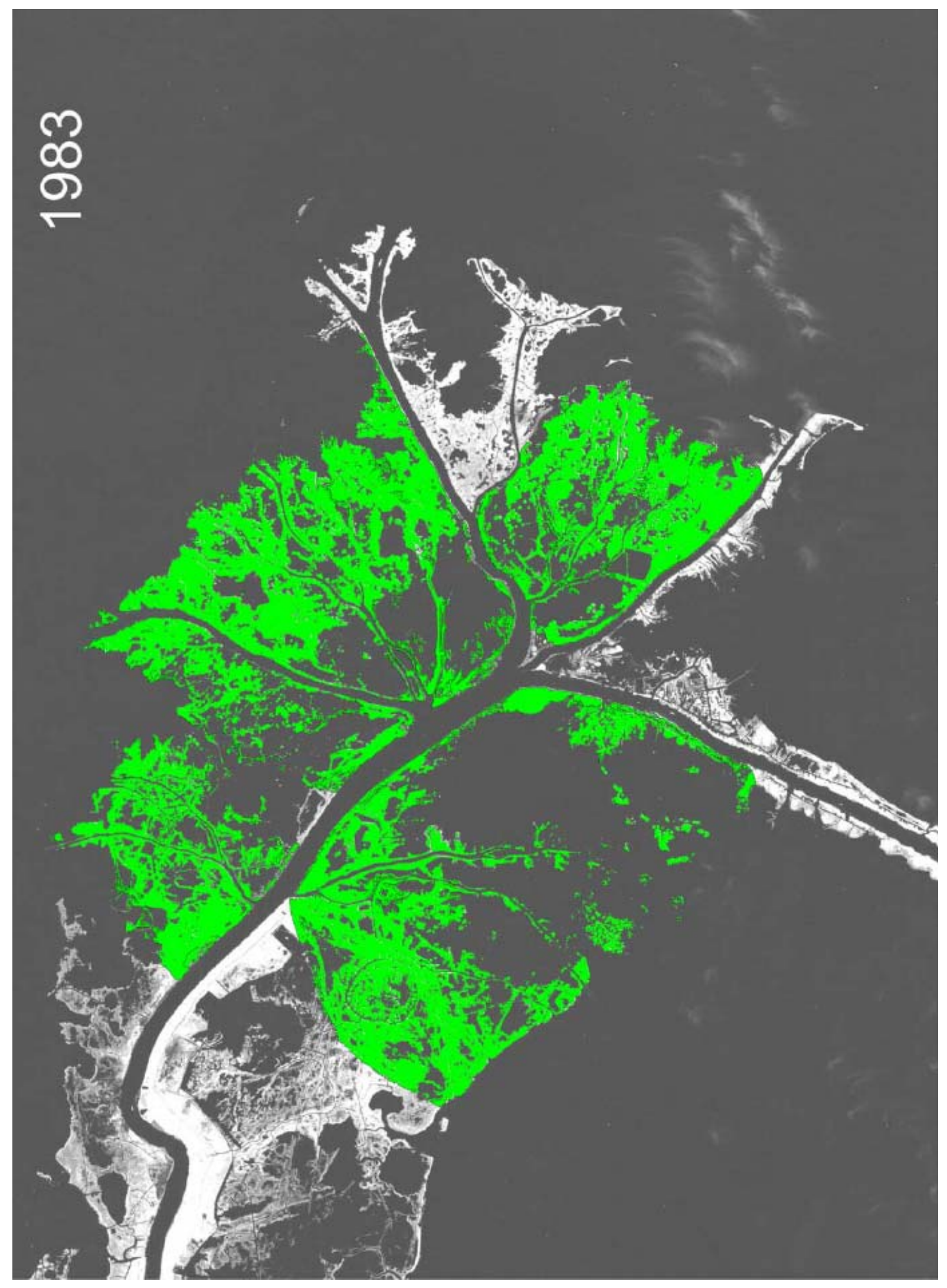




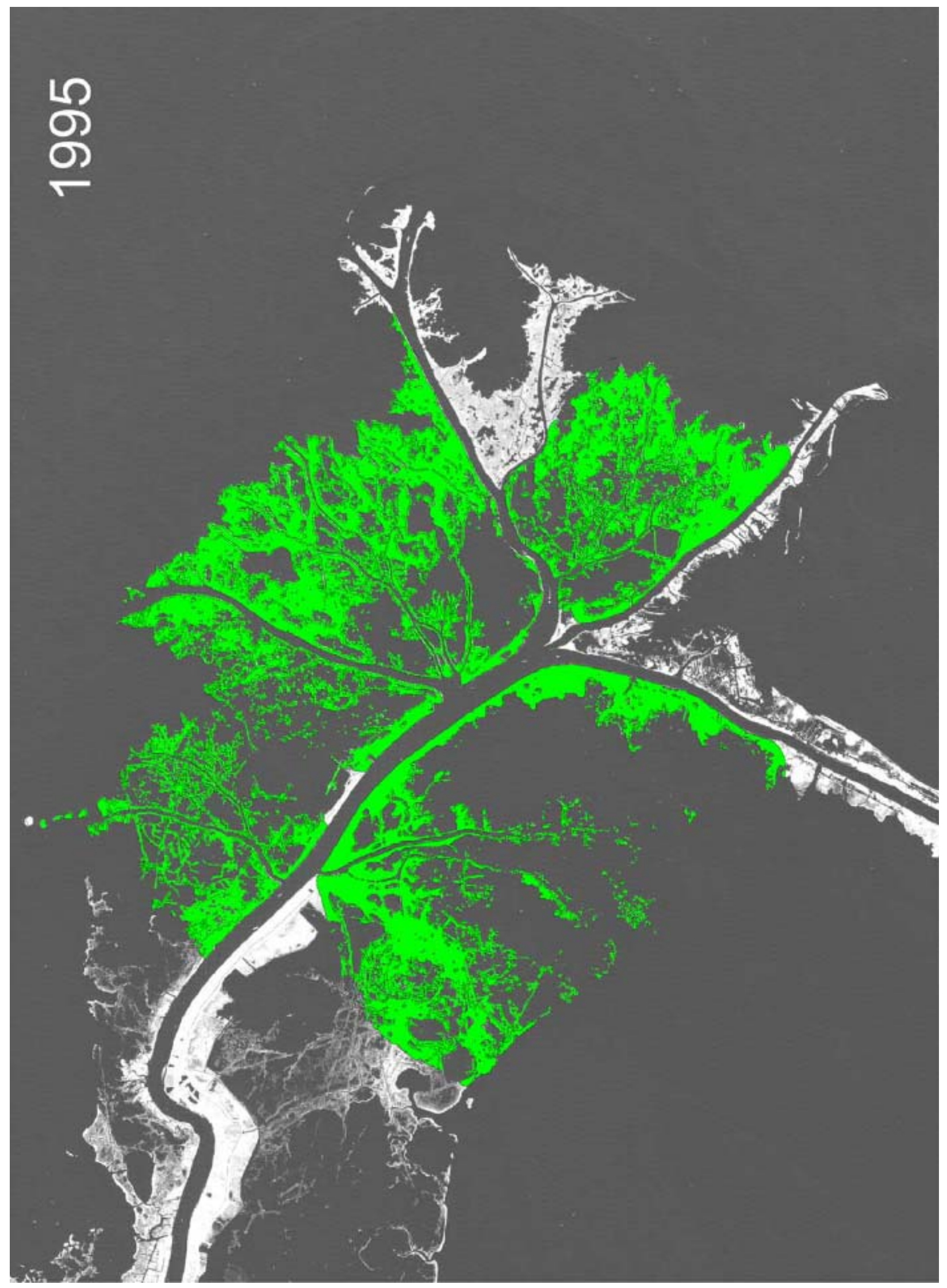




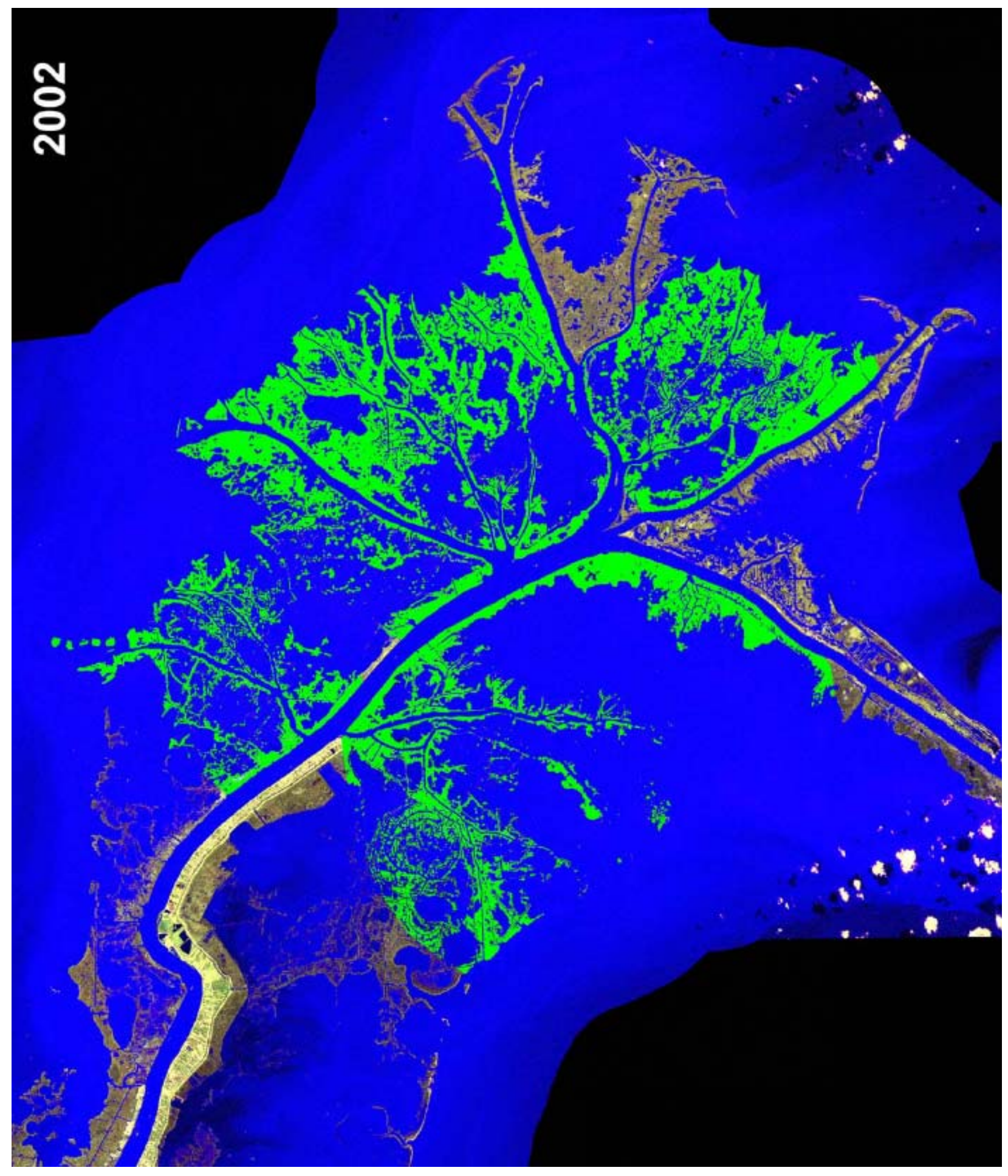


APPENDIX B

FIELD WORK SUMMARY 


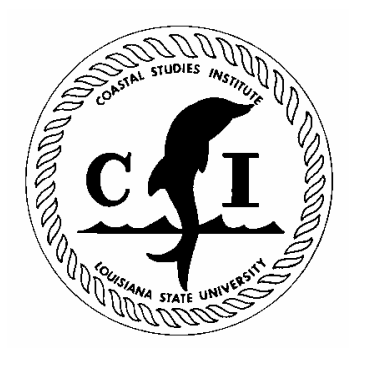

Coastal Studies Institute L.S.U. Field Support Building Baton Rouge, LA. 70803

Office of Capt. Steve Dartez Phone: (225) 578-8606 Fax: (225) 578-2898

Email: jdarte1@1su.edu

\title{
West Bay, LA \\ Surveys and Instrument Deployments Summary of Actions Coastal Studies Institute Field Support Group (CSI-FSG)
}

\author{
$\underline{\text { Scientist }}$ \\ Mitch Andrus P.E. \\ Dr. Sam Bentley \\ Dr. Alex Sheremet
}

\section{Field Support Staff Capt. Steve Dartez Darren Depew}




\section{Table of Contents}

1) November 2-4, 2005 - Bathymetric survey and sediment cores. (Page 3)

2) February 8, 2006 - Instrumentation deployment in diversion cut. (page 4)

3) March 7, 2006 - ADCP survey and instrument re-location (page 5)

4) March 21, 2006 - Instrument service and re-location (page 8)

5) April 12-14, 2006 - Bathymetric survey, sediment cores, and instrument removal (page 9)

6) Coastal Studies Institute - Field Support Group project manager contact information (page 15)

7) Sub-appendix A - ASCII data file formats and file name conventions (page 16)

8) Sub-appendix B - Site location coordinates (page 21)

9) Sub-appendix C - Relevant web sites and instrument information (page 22)

10) Sub-appendix D - Photos (page 23)

11) Sub-appendix E - November 2005 survey line plot (page 28)

12) Sub-appendix F - April 2006 survey line plot (page 29)

13) Sub-appendix G - Diagram of Aquadopp velocities in the diversion cut. (page 30)

Note: All coordinates for named sites can be found in Sub-appendix B 


\section{November 1-4, 2005 - Bathymetric Survey and Sediment Cores}

November 1, 2005 - Bathymetric Survey and Sediment Cores

A crew consisting of Steve Dartez, Darren Depew, and Mitch Andrus departed the CSIFSG campus facility for the transit to Venice, LA. After several hours of locating a place to launch the vessel, a launch ramp at Venice Marina was obtained. The R/V Acadiana arrived shortly and we followed it down the river to the Head of Passes on the Mississippi River where the Acadiana would be used as a base of operations for the next several days. The rest of the evening was used to prepare the survey vessel for operations.

\section{November 2, 2005 - Bathymetric Survey and Sediment Cores}

The crew departed for the West Bay survey area and arrived at the site to locate the tide gauge. The tide gauge deployment site was designated “WB-Tide”. An aluminum bench-mark was established on the piling for later survey verification. The tide gauge was installed and the vessel was relocated to survey Line 1-2 for the bathymetric survey. After complications on survey Line 3-4 it was determined that the power supplies for the external monitor was defective and that the DC supply for the computer was not working. The crew continued to survey until survey Line 7-8 when the computer's battery was exhausted. The crew returned to the R/V Acadiana for evaluation of repairs. Dr. Sam Bentley was met in Venice by the Acadiana and was now part of the survey crew.

\section{November 3, 2005 - Bathymetric Survey and Sediment Cores}

Crew departed for the core locations early in the morning. Magnetite plots were located at core locations designated WB03-A and WB02-A. Sites were marked with two PVC pipes at each location. A push core and X-ray slab was taken at each site between the locator pipes and an additional push core was taken away from the plot at WB03-A and WB02-A. The flow at WB01-A was estimated at $3 \mathrm{~m} / \mathrm{s}$. Indications show there was much scouring and remnant tree stumps. Site may be radioisotopically dead if scoured from last sub-delta survey. Coring continued through the rest of the day with cores sites WB04-A, WB05-A, WB06-A, WB07-A, WB08-A, WB09-A, WB10-A, WB12-A, and WB15-A being collected.

\section{November 4, 2005 - Bathymetric Survey and Sediment Cores}

The crew returned to the survey site to try and obtain some additional lines of bathymetric data. Data will be collected until the computer battery power is exhausted. It was decided that a survey of the diversion cut and a line from the cut south to survey Line 13-14 would provide good information to the overall information collected. After these lines were completed survey Line 13-14 and Line 17-18 were done concentrating on the middle of the bay. After all data was saved the crew departed for Venice Marina.

See Sub-appendix F for survey line plot 


\section{February 8, 2006 - Instrumentation Deployment}

\section{February 8, 2006 - Instrumentation Deployment in Diversion Cut}

A crew consisting of Steve Dartez, Darren Depew, and Mitch Andrus departed the CSIFSG campus facility for the transit to Venice, LA for the purpose of installing instruments and mounting platform in the diversion cut from the Mississippi River to West Bay. The crew arrived on site and established the proposed location for the platform at site designated WB-Cut. The water depth at the time of platform construction was measured at $3.8 \mathrm{~m}$. The instrument platform was constructed using three aluminum core tubes of 4" diameter installed in the seabed using a vibracore adaptor. After the three main legs of the platform were installed several cross-brace boards were installed between the verticals for stability. The instruments to be mounted on the platform will be a Nortek Aquadopp ADCP and an YSI 6600 sonde. The Nortek will be placed a height of $1.82 \mathrm{~m}$ from the seabed looking out across the channel to the north. The YSI sonde was mounted with the pressure sensor $2.18 \mathrm{~m}$ above the bottom. The conductivity and temperature from the sonde was $2.06 \mathrm{~m}$ and the turbidity was $1.98 \mathrm{~m}$ above the bottom. Both instruments were set to begin logging at 2200hrs GMT. After the installation the crew departed for home. See Subappendix $\mathrm{G}$ for diagram of deployment. 


\section{March 7, 2006 - ADCP survey and Instrument $\underline{\text { Re-location }}$}

\section{March 7, 2006 - ADCP survey and Instrument Re-location}

A crew consisting of Steve Dartez and Daren Depew, both of CSI-FSG departed the campus facilities for the transit to Venice, LA. After arriving at Venice Marina in Venice, LA the crew prepared the research vessel for the day's activities. The vessel arrived on station at the diversion canal instrumentation site at 1700hrs GMT. The first station to acquire ADCP profile data was designated WB\#1. The crew positioned the vessel into the current flow coming from the river through the diversion. The vessel was anchored and the ADCP was lowered over the bow. The ADCP was set to $0.48 \mathrm{~m}$ below the surface in a water depth of $10.05 \mathrm{~m}$. Data collection began at $1756 \mathrm{hrs}$ GMT. Station WB\#1 is approximately $12 \mathrm{~m}$ north of the instrument platform. The ADCP obtained current velocities at $0.25 \mathrm{~m}$ intervals vertically in the water column. After collecting data continuously at approximately 1 second per ping the collection was stopped at 1827hrs GMT. The vessel was relocated to the middle of the channel north of the instrument platform and designated WB\#2. Data collection at site WB\#2 began at 1848hrs GMT and concluded at 1919hrs GMT. The water depth at WB\#2 was measured at $17.37 \mathrm{~m}$. The instrument was collecting data at 1.6 seconds per ping at this depth. The vessel was relocated to the next site designated WB\#3 which was located on the north side of the diversion channel north of the instrument platform and approximately $12 \mathrm{~m}$ from the shore. The water depth of $5.18 \mathrm{~m}$ was measure at WB\#3. Data collection began at 1932hrs GMT and concluded at 2002hrs GMT. The data was collected at 0.70 seconds per ping. At the conclusion of the cross channel survey two additional site were identified to collect data in the main flow of the current leading into the bay. A site in the center of the channel and west of the instrument platform was designated WB\#4. The water depth at this site was measured at $8.84 \mathrm{~m}$. Data collection began at 2013hrs GMT and concluded at 2032hrs GMT. The collection times at the two additional sites were limited from 30 minutes to 20 minutes due to time constraints. The next station was located to the south of WB\#4 and west of WB\#1. The last location was designated as WB\#5 with a water depth of $5.18 \mathrm{~m}$. Data collection began at 2040hrs GMT and concluded at 2059hrs GMT. The data was collected at 0.70 seconds per ping. Station information particulars are as follows:

WB\#1 -

Location: $29^{\circ} 12.670^{\prime} \mathrm{N}$ by $89^{\circ} 17.575^{\prime} \mathrm{W}-40$ feet north of instruments

Water depth: 10.05 meters

Start of profiles: 17:56 GMT

End of profiles: 18:27 GMT

ADCP approximately 0.48 meters below the surface

Cells size $=0.25$ meters, Blanking distance 0.5 meters

$1^{\text {st }}$ cell at $=($ blanking $+1 / 2$ cells size $)+$ transducer depth $=0.5+0.125+0.48=1.11 \mathrm{~m}$

Time per profile $=0.99 \mathrm{sec} /$ profile

Data Averaging $=60$ profiles per data block 
WB\#2 -

Location: $29^{\circ} 12.688^{\prime} \mathrm{N}$ by $89^{\circ} 17.580^{\prime} \mathrm{W}$ - Middle of cut

Water depth: 17.37 meters

Start of profiles: 18:48 GMT

End of profiles: 19:19 GMT

ADCP approximately 0.48 meters below the surface

Cells size $=0.25$ meters, Blanking distance 0.5 meters

$1^{\text {st }}$ cell at $=($ blanking $+1 / 2$ cells size $)+$ transducer depth $=0.5+0.125+0.48=1.11 \mathrm{~m}$

Time per profile $=1.6 \mathrm{sec} /$ profile

Data Averaging $=60$ profiles per data block

WB\#3 -

Location: $29^{\circ} 12.720^{\prime} \mathrm{N}$ by $89^{\circ} 17.576^{\prime} \mathrm{W}$ - North side of cut -40 feet from shore

Water depth: 5.18 meters

Start of profiles: 19:32 GMT

End of profiles: 20:02 GMT

ADCP approximately 0.48 meters below the surface

Cells size $=0.25$ meters, Blanking distance 0.5 meters

$1^{\text {st }}$ cell at $=($ blanking $+1 / 2$ cells size $)+$ transducer depth $=0.5+0.125+0.48=1.11 \mathrm{~m}$

Time per profile $=0.70$ sec/profile

Data Averaging $=60$ profiles per data block

WB\#4 -

Location: $29^{\circ} 12.694^{\prime} \mathrm{N}$ by $89^{\circ} 17.656^{\prime} \mathrm{W}$ - Middle of cut west of instruments

Water depth: 8.84 meters

Start of profiles: 20:13 GMT

End of profiles: 20:32 GMT

ADCP approximately 0.48 meters below the surface

Cells size $=0.25$ meters, Blanking distance 0.5 meters

$1^{\text {st }}$ cell at $=($ blanking $+1 / 2$ cells size $)+$ transducer depth $=0.5+0.125+0.48=1.11 \mathrm{~m}$

Time per profile $=0.99$ sec/profile

Data Averaging $=60$ profiles per data block

WB\#5 -

Location: $29^{\circ} 12.672^{\prime} \mathrm{N}$ by $89^{\circ} 17.650^{\prime} \mathrm{W}$ - West of instruments, 30ft from shore

Water depth: 5.18 meters

Start of profiles: 20:40 GMT

End of profiles: 20:59 GMT

ADCP approximately 0.48 meters below the surface

Cells size $=0.25$ meters, Blanking distance 0.5 meters

$1^{\text {st }}$ cell at $=($ blanking $+1 / 2$ cells size $)+$ transducer depth $=0.5+0.125+0.48=1.11 \mathrm{~m}$

Time per profile $=0.70 \mathrm{sec} /$ profile

Data Averaging $=60$ profiles per data block 
The instruments on the deployment platform in the diversion were removed from the mount at 2121hrs GMT. The YSI 6600 sonde data was downloaded to the computer under filename WESTBAY1.dat. There were 3885 samples collected during this deployment. The instrument was set to begin logging data again at 2300hrs GMT. The Nortek Aquadopp ADCP was downloaded to filename Wbcut01.prf. There were 158112 bytes of data collected during this deployment. The instruments battery was replaced. The changes made to the configuration of the Nortek consisted of orienting the sensor head downward, cell volumes set to 17 and the cell size set to $10 \mathrm{~cm}$. The wave function was selected and set to record every $0.5 \mathrm{hrs}$ for 2048 samples at $2 \mathrm{~Hz}$ with a cell size of $0.2 \mathrm{~m}$. The instrument was set to begin logging again at 2300hrs GMT. The CSI Wave/Turbidity gauge was set to begin logging at 2300hrs GMT. The instruments were relocated to a site previously used for the tide measurements during the first bathymetric survey in November 2005. The designation of the mid-bay instrument location is WB-Mid. The water depth at the time of deployment was $1.9 \mathrm{~m}$. The Nortek was mounted at a height of $1.5 \mathrm{~m}$ from the bottom. The YSI pressure sensor was placed at 0.8 meters and the sensors 0.6 meters from the bottom. The CSI Wave/Turbidity sensor was started logging at 23:00 GMT. Sampling interval is set at 3 hours. The pressure is measured at $2 \mathrm{~Hz}$ continuously over 2 hours and 50 minutes. The turbidity sensors are measured once every 3 hours. The pressure sensor was mounted 1.0 meters from the bottom. OBS \#2 was mounted 0.5 meters and OBS \#3 was mounted $0.25 \mathrm{~m}$ from the bottom. OBS \#1 was not installed in the instrument. All instruments were in the water by 22:55 GMT.

The ADCP profile data from the RD Instruments used in the vertical profile survey and the deployed instruments have the following ASCII format that can be found in Sub-appendix A. Photos of the profiling ADCP setup can be found in Sub-appendix D. References for specifications for the RD Instruments ADCP can be found in Sub-appendix C. 


\section{March 21, 2006 - Instrument Service and $\underline{\text { Re-location }}$}

March 21, 2006 - Instrument Service and Re-location

A crew from CSI-FSG consisting of Steve Dartez and Darren Depew departed LSU for Venice Marina in Venice, LA. The crew was on site at the instrument location at 1900 GMT. The Nortek Aquadopp was downloaded to the filename Wbmid01.prf. The data from the instrument indicated that the battery only provided power for data collection for approximately 8 days. The YSI 6600 sonde was downloaded to the computer under filename WesBay2.dat. There were 1993 samples stored in the sonde. The CSI WavelTurbidity gauge was left running and was not downloaded due to the difficulty of opening the instrument in an open boat at sea. The YSI was set to begin logging again at 2200hrs GMT. The new location on the south side of the bay was designated WB-Sth with a water depth of $2.8 \mathrm{~m}$ at the time of deployment. The CSI gauge was deployed at $2012 \mathrm{hrs}$ GMT. The CSI pressure sensor was $1.5 \mathrm{~m}$ off the bottom. The OBS sensor \#2 was located $0.74 \mathrm{~m}$ off the bottom and OBS sensor \#3 was located $0.96 \mathrm{~m}$ off the bottom. The sea state became too rough to safely deploy the Nortek current meter and the YSI sonde. These instruments were relocated back to the WB-Mid site with the YSI pressure sensor $0.76 \mathrm{~m}$ off the bottom. 


\section{April 12-14, 2006 - Bathymetric Survey, Sediment Cores, and Instrument Removal}

\section{April 12, 2006 - Bathymetric Survey, Sediment Cores, and Instrument Removal}

A crew consisting of Steve Dartez, Darren Depew, and Mitch Andrus departed Venice

Marina to collect sediment cores. The following are a listing of the core sites and the information at each site.

Core Site: WB01-B

On station at: 07:30 CST.

Coordinates: $29^{\circ} 12.585^{\prime} \mathrm{N}$ by $89^{\circ} 17.906^{\prime} \mathrm{W}$

Water depth: $1.2 \mathrm{~m}$

Water sample time: 08:30 CST

A push core and an X-Ray slab core were taken

Core Site: WB02-B

On station at: 08:55 CST.

Coordinates: $29^{\circ} 12.116^{\prime} \mathrm{N}$ by $89^{\circ} 18.101^{\prime} \mathrm{W}$

Water depth: $1.65 \mathrm{~m}$

Water sample time: 09:20 CST

A push core and an X-Ray slab core were taken

Core Site: WB10-B

On station at: 09:40 CST.

Coordinates: $2^{\circ} 11.330^{\prime} \mathrm{N}$ by $89^{\circ} 18.221^{`} \mathrm{~W}$

Water depth: $1.6 \mathrm{~m}$

Water sample time: 09:55 CST

A push core and an X-Ray slab core were taken

Core Site: WB12-B

On station at: 10:20 CST.

Coordinates: $29^{\circ} 10.750$ ’ $\mathrm{N}$ by $89^{\circ} 16.961^{\prime} \mathrm{W}$

Water depth: $0.62 \mathrm{~m}$

Water sample time: 10:30 CST

A push core and an X-Ray slab core were taken

Core Site: WB15-B

On station at: 11:10 CST.

Coordinates: $29^{\circ} 09.551^{\prime} \mathrm{N}$ by $89^{\circ} 16.940^{\prime} \mathrm{W}$

Water depth: $1.1 \mathrm{~m}$

Water sample time: 11:20 CST

A push core was taken. X-ray slab was unable to be collected. Sediment was similar to that taken in November 2005 
Core Site: WB17-B

On station at: 12:15 CST.

Coordinates: $29^{\circ} 07.939^{\prime} \mathrm{N}$ by $89^{\circ} 17.464^{\prime} \mathrm{W}$

Water depth: $1.1 \mathrm{~m}$

Water sample time: 12:25 CST

A push core and an X-Ray slab core were taken

Core Site: WB06-B

On station at: 13:00 CST.

Coordinates: $29^{\circ} 09.479^{\prime} \mathrm{N}$ by $89^{\circ} 19.454^{\prime} \mathrm{W}$

Water depth: $0.85 \mathrm{~m}$

Water sample time: 13:10 CST

A push core and an X-Ray slab core were taken

Core Site: WB05-B

On station at: 14:00 CST.

Coordinates: $29^{\circ} 10.250^{\prime} \mathrm{N}$ by $89^{\circ} 19.808^{\prime} \mathrm{W}$

Water depth: $0.70 \mathrm{~m}$

Water sample time: 14:20 CST

A push core and an X-Ray slab core were taken

Core Site: WB04-B

On station at: 15:05 CST.

Coordinates: $29^{\circ} 10.989^{\prime} \mathrm{N}$ by $89^{\circ} 19.514^{\prime} \mathrm{W}$

Water depth: $0.70 \mathrm{~m}$

Water sample time: 15:10 CST

A push core and an X-Ray slab core were taken

Core Site: WB03-B

On station at: 15:25 CST.

Coordinates: $29^{\circ} 11.696^{\prime} \mathrm{N}$ by $89^{\circ} 19.062^{\prime} \mathrm{W}$

Water depth: $1.2 \mathrm{~m}$

Water sample time: 08:30 CST

A push core and an X-Ray slab core were taken

The survey tide gauge was located at the same location WB-Tide. The water depth at the site was $2.6 \mathrm{~m}$. The pressure sensor was located $1.86 \mathrm{~m}$ from the bottom. The instrument was in the water at 14:00 CST. The crew departed for Venice Marina. 


\section{April 13, 2005 - Bathymetric Survey and Instrument Removal}

The crew arrived at the study area to perform the bathymetric survey. The survey began with a cross channel survey at the mouth and the instrument platform. The filename for this cross channel survey is "Westbay2006_L_Line 33-34_060413_125839"

The filename convention is the project title "Westbay2006_L" then the line designation “_Line 33-34" then the date "_yymmdd" then the time “_hhmmss". After the cross channel survey was completed a line was run from the diversion to the southern most area down what is believed to be the main current flow pattern. This line was given the filename "Westbay2006_L_Line 3132_060413_131357". The following is the events of the main survey lines.

Line 1-2

Filename: Westbay2006_L_Line1-2_060413_143813

Start Time: ?

Stop Time: ?

Direction: Northeast

Notes: Start of line 0.03nm from core site WB\#17B

Line 3-4

Filename: Westbay2006_L_Line3-4_060413_151440

Start Time: 1516hrs GMT

Stop Time: 1549hrs GMT

Direction: Southwest

Line 5-6

Filename: Westbay2006_L_Line5-6_060413_155243

Start Time: 1553hrs GMT

Stop Time: $1634 \mathrm{hrs}$ GMT

Direction: Northeast

Notes: Starting line much closer to shore than the November 2005 survey

Line 7-8

Filename: Westbay2006_L_Line7-8_060413_163938

Start Time: 1640hrs GMT

Stop Time: 1726hrs GMT

Direction: Southwest

Notes: Winds increasing to $10-12 \mathrm{kts}$ out of the east

Line 9-10 - Not surveyed

Line 11-12

Filename: Westbay2006_L_Line11-12_060413_172615

Start Time: 1733hrs GMT

Stop Time: 1810hrs GMT

Direction: Northeast 
Line 13-14

Filename: Westbay2006_L_Line13-14_060413_181209

Start Time: 1814hrs GMT

Stop Time: 1845hrs GMT

Direction: Southwest

Line 15-16 - Not surveyed

Line 17-18

Filename: Westbay2006_L_Line17-18_060413_185257

Start Time: 1854hrs GMT

Stop Time: 1930hrs GMT

Direction: Northeast

Notes: Line ended at core site WB-03

Line 19-20

Filename: Westbay2006_L_Line19-20_060413_193308

Start Time: 1934hrs GMT

Stop Time: ?

Direction: Southwest

Line 21-22

Filename: Westbay2006_L_Line21-22_060413_203023

Start Time: 2030hrs GMT

Stop Time: 2050hrs GMT

Direction: Northeast

Line 23-24

Filename: Westbay2006_L_Line23-24_060413_205636

Start Time: 2055hrs GMT

Stop Time: 2104hrs GMT

Direction: Southwest

Line 25-26

Filename: Westbay2006_L_Line25-26_060413_210843

Start Time: 2109hrs GMT

Stop Time: 2116hrs GMT

Direction: Northeast

Line 27-28

Filename: Westbay2006_L_Line27-28_060413_211933

Start Time: 2120hrs GMT

Stop Time: 2126hrs GMT

Direction: Southwest 
Line 29-30

Filename: Westbay2006_L_Line29-30_060413_212922

Start Time: 2130hrs GMT

Stop Time: 2138hrs GMT

Direction: Northeast

Line 31-32

Filename: Westbay2006_L_Line31-32_060413_214147

Start Time: 2141hrs GMT

Stop Time: 2150hrs GMT

Direction: Southwest

Notes: Line started at core site WB-01

Line 33-34 - Not Surveyed

See Sub-appendix F for survey line plot

The CSI WavelTurbidity Gauge was removed from the south deployment site at 1410hrs GMT. The instrument was stopped logging and contained 13Mb of data for the last month of deployment.

\section{April 14, 2006 - Bathymetric Survey and Instrument Removal}

The crew set out to the survey area for the completion of the core sites not sampled on the first day. The following list the details.

Core Site: WB07-B

On station at: 08:30 CST.

Coordinates: $29^{\circ} 08.696^{\prime} \mathrm{N}$ by $89^{\circ} 18.512^{\prime} \mathrm{W}$

Water depth: $2.4 \mathrm{~m}$

Water sample time: 08:45 CST

A push core and an X-Ray slab core were taken

Core Site: WB08-B

On station at: 09:25 CST.

Coordinates: $29^{\circ} 09.583^{\prime} \mathrm{N}$ by $89^{\circ} 18.409^{\prime} \mathrm{W}$

Water depth: $1.78 \mathrm{~m}$

Water sample time: 09:35 CST

A push core and an X-Ray slab core were taken

Core Site: WB09-B

On station at: 10:10 CST.

Coordinates: $29^{\circ} 10.392^{\prime} \mathrm{N}$ by $89^{\circ} 18.219^{\prime} \mathrm{W}$

Water depth: $1.8 \mathrm{~m}$

Water sample time: 10:10 CST

A push core and an X-Ray slab core were taken 
The crew then relocated to WB-Tide and removed the survey tide gauge, the YSI 6600 sonde, and the Nortek Aquadopp ADCP. All instruments were stopped from logging. The crew then departed for home. Steve Dartez downloaded all of the instruments recovered from the project. This final report was compiled and a data disk produced. 


\title{
$\underline{\text { Project Manaqer Contact Information }}$
}

Any questions about the operations of Coastal Studies Institute - LSU on this project may be directed to:

\author{
Capt. Steve Dartez \\ Coastal Studies Institute - LSU \\ Field Support Group \\ Louisiana State University \\ $3^{\text {rd }}$ Floor Old Geology Building \\ Baton Rouge, LA 70803 \\ 225-578-8606 phone \\ 225-578-2898 fax \\ jdarte1@lsu.edu
}




\section{$\underline{\text { Sub-appendix A }}$}

\section{Filename Conventions:}

Bathymetric Data:

Data can be found in the November 2005/Bathymetric Data directory and the April 14, 2006/Bathymetric Data directory.

Filenames contain the following format "title_L_line name_yymmdd_hhmmss.txt" where $\mathrm{yy}=$ year, $\mathrm{mm}=$ month, $\mathrm{dd}=$ day, $\mathrm{hh}=$ hours, $\mathrm{mm}=$ mintues, $\mathrm{ss}=$ seconds.

There are Microsoft Excel files for each line that contain the conversion of the depth from meters to feet.

Aquadopp Data:

Files named WBcut01 in the March 7, 2006/Aquadopp directory are from data collected in the diversion cut.

Files named WBmid01 in the March 21, 2006/Aquadopp directory are from data collected in the middle of the bay.

Files named WBsth01 in the April 14, 2006/Aquadopp directory are from data collected again in the middle of the bay since weather did not permit deployment on the south end of the bay. (see field summary)

ADCP Data:

Data can be found in the March 7, 2006/ADCP Profiles directory. File names correspond to the site location names given in the summary report. The files named westbay\#t.000 are the ASCII files containing the processed profile data. See ADCP listing below in Sub-appendix A for file description.

YSI Data:

File named WESTBAY1.xls in the March 7, 2006/YSI directory contains the processed data for the YSI deployed in the diversion cut.

File named WESTBAY2.xls in the March 21, 2006/YSI directory contains the processed data for the YSI deployed in the middle of the bay.

File named WESTBAY3.xls in the April 14, 2006/YSI directory contains the processed data for the YSI again deployed in the middle of the bay since weather did not permit deployment on the south end of the bay.

CSI Wave and Turbidity Data:

Files in the April 14, 2006/CSI Wave directory with the .ASC extension are the processed data files. See below in Sub-appendix

A for the file format.

Tide Data:

Microsoft Excel file in the November 2005/Tide Data directory contains the tide data collected during the bathymetric survey.

Microsoft Excel file in the April 14, 2005/Tide Data directory contains the tide data collected during the bathymetric survey. 


\section{ASCII Data Formats:}

YSI 6600 Sonde: See Microsoft Excel file (self explanatory)

Nortek Aquadopp:

WBcut01.v1 -

- Velocity data in $\mathrm{m} / \mathrm{s}$ for each cell listed across.

- Each line represents data collected every $1 / 2$ hour and is a 2 minute average.

- A positive value indicates a flow from the bay to the river or west to east.

- These values are the horizontal flow component, where each cell to position 0.5 meters apart horizontally reaching away from the instrument to the north.

WBcut01.v2 and WBcut01.v3 are the $\mathrm{Y}$ and $\mathrm{Z}$ components of the profile and may be of use if the cell window does not see the surface or bottom. The $\mathrm{Z}$ component (.v3) is the velocity of currents flowing cross channel with a positive value representing flows moving from south to north. The Y component (.v2) is the vertical velocities with a positive value representing a downward flow.

WBmid01.v1, WBmid01.v2, WBmid01.v3, WBsth01.v1, WBsth01.v2, WBsth01.v3 are velocity files in east, north, and up components. WBsth01 files are data collected from the middle bay location as well (see March 21, 2006 notes for explanation)

CSI Wave / Turbidity Gauge:

File convention: .ASC are the processed files. The file name convention is the HHMMDDMM.asc. Where $\mathrm{HH}=$ hour, $\mathrm{MM}=$ minute, $\mathrm{DD}=$ day, $\mathrm{MM}=$ month. The first line will have the date and time of the first record. The next value is the temperature of the pressure transducer. Following the temperature are 1200 readings of pressure in psig, read from left to right top to bottom. This repeats until 20400 pressure samples have been recorded. The last line contains the time, OBS\#1, OBS \#2, OBS \#3, and the battery voltage. In the case of West Bay OBS\#1 was not used.

(continued next page) 


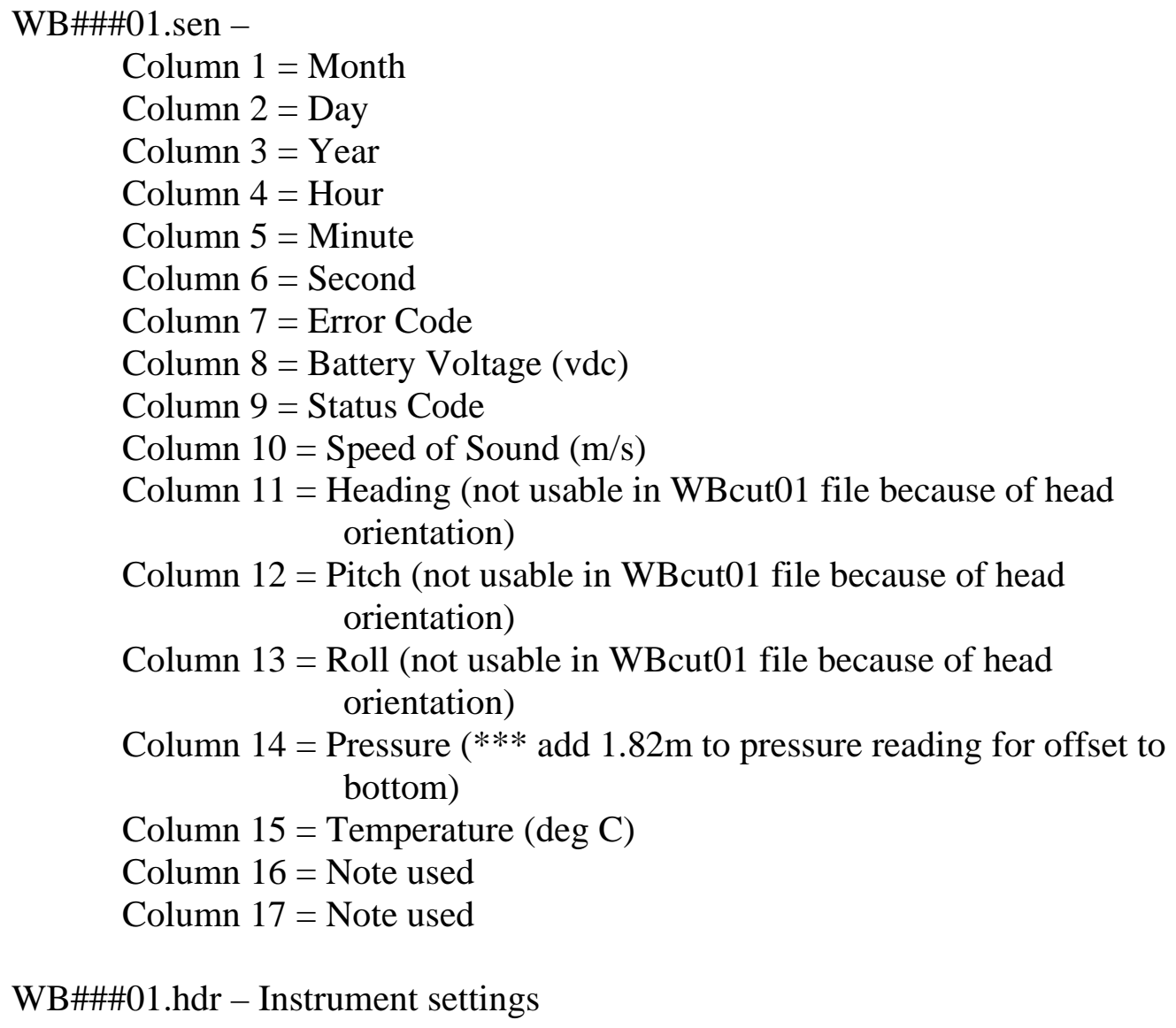

WB\#\#\#01.a1, WB\#\#\#01.a2, WB\#\#\#01.a3 are the amplitude files. Units are in counts and the data format is the same as the velocity files.

(continued next page) 
WBmid01.whd and WBsth01.whd -

Column 1 = Month

Column 2 = Day

Column $3=$ Year

Column $4=$ Hour

Column $5=$ Minute

Column $6=$ Second

Column 7 = \# of wave records

Column 8 = Blanking distance for wave cell (m)

Column 9 = Battery Voltage (vdc)

Column $10=$ Speed of Sound $(\mathrm{m} / \mathrm{s})$

Column $11=$ Heading $(\mathrm{deg})$

Column $12=$ Pitch $($ deg $)$

Column $13=$ Roll (deg)

Column $14=$ Minimum Pressure (m)

Column $15=$ Maximum Pressure $(\mathrm{m})$

Column $16=$ Temperature $(\operatorname{deg} \mathrm{C})$

Column $17=$ Cell Size $(\mathrm{m})$

Column 18 = Noise Amplitude beam 1 (counts)

Column $19=$ Noise Amplitude beam 2 (counts)

Column $20=$ Noise Amplitude beam 3 (counts)

Column 21 = Noise Amplitude beam 4 (counts) (not used)

Column 22 = Processing Magnitude beam 1 (counts) (not used)

Column 23 = Processing Magnitude beam 2 (counts) (not used)

Column 24 = Processing Magnitude beam 3 (counts) (not used)

Column 25 = Processing Magnitude beam 4 (counts) (not used)

WBmid01.wad and WBsth01.wad -

Column 1 = Counter

Column 2 = Pressure $(\mathrm{m})$

Column 3 = Distance to Vertical Beam (m) (not used)

Column $4=$ Analog input (not used)

Column $5=$ Velocity (east) $(\mathrm{m} / \mathrm{s})$

Column $6=$ Velocity (north) $(\mathrm{m} / \mathrm{s})$

Column 7 = Velocity (up) $(\mathrm{m} / \mathrm{s})$

Column 8 = Velocity (beam 4) (not used)

Column 9 = Amplitude (beam 1) (counts)

Column 10 = Amplitude (beam 2) (counts)

Column 11 = Amplitude (beam 3) (counts)

Column 12 = Amplitude (beam 4) (counts) (not used) 
RD Instruments ADCP Profiles:

Westbay1t.000, Westbay2t.000, Westbay3t.000, Westbay4t.000, Westbay5t.000 -

The first line in the file is instrument settings

Lines 2 to 8 are collection settings and are repeated every profile. The first line contains the year (6), month (3), day (7), hour, min, sec, and other values not needed in interpretation. The remaining columns in the profile before the next block header described above have the following format.

Column 1 = Cell depth

Column 2 = velocity magnitude $(\mathrm{cm} / \mathrm{s})$

Column 3 = velocity direction (deg)

Column 4 = East velocity $(\mathrm{cm} / \mathrm{s})$

Column $5=$ North velocity $(\mathrm{cm} / \mathrm{s})$

Column $6=$ Up velocity $(\mathrm{cm} / \mathrm{s})$

Column 7 = Error velocity $(\mathrm{cm} / \mathrm{s})$

Column 8 = Beam 1 backscatter (dB)

Column 9 = Beam 2 backscatter $(\mathrm{dB})$

Column $10=$ Beam 3 backscatter $(\mathrm{dB})$

Column $11=$ Beam 4 backscatter $(\mathrm{dB})$

Column $12=$ Percent good pings (\%)

Column 13 = Not used 


\section{$\underline{\text { Sub-appendix } B}$}

Instrumentation site coordinates:

WB-Tide $=29^{\circ} 10.020^{\prime} \mathrm{N}$ by $89^{\circ} 18.945^{\prime} \mathrm{W}$

WB-Cut $=29^{\circ} 12.657^{\prime} \mathrm{N}$ by $89^{\circ} 17.572^{\prime} \mathrm{W}$

WB-Mid $=29^{\circ} 10.020^{\prime} \mathrm{N}$ by $89^{\circ} 18.945^{\prime} \mathrm{W}$

WB-Sth $=29^{\circ} 08.431^{\prime} \mathrm{N}$ by $89^{\circ} 18.409^{\prime} \mathrm{W}$

\section{ADCP survey site locations:}

$\mathrm{WB} \# 1=29^{\circ} 12.670^{\prime} \mathrm{N}$ by $89^{\circ} 17.575^{\prime} \mathrm{W}$

$\mathrm{WB} \# 2=29^{\circ} 12.688^{\prime} \mathrm{N}$ by $89^{\circ} 17.580^{\prime} \mathrm{W}$

$\mathrm{WB} \# 3=29^{\circ} 12.720^{\prime} \mathrm{N}$ by $89^{\circ} 17.576^{\prime} \mathrm{W}$

$\mathrm{WB} \# 4=29^{\circ} 12.694^{\prime} \mathrm{N}$ by $89^{\circ} 17.656^{\prime} \mathrm{W}$

$\mathrm{WB} \# 5=29^{\circ} 12.672^{\prime} \mathrm{N}$ by $89^{\circ} 17.650^{\prime} \mathrm{W}$

Core site coordinates where cores were obtained in November 2005:

WB01-A = 29 $12.584^{\prime} \mathrm{N}$ by $89^{\circ} 17.903^{\prime} \mathrm{W}$

WB02-A = 29 $12.116^{\prime}$ N by $89^{\circ} 18.101^{\prime} \mathrm{W}$

WB03-A $=29^{\circ} 11.701^{\prime} \mathrm{N}$ by $89^{\circ} 19.063^{\prime} \mathrm{W}$

WB04-A = 29 $10.999^{\prime} \mathrm{N}$ by $89^{\circ} 19.518^{\prime} \mathrm{W}$

WB05-A = 29 $10.256^{\prime}$ $\mathrm{N}$ by $89^{\circ} 19.805^{\prime} \mathrm{W}$

WB06-A $=29^{\circ} 09.487^{\prime} \mathrm{N}$ by $89^{\circ} 19.447^{\prime} \mathrm{W}$

WB07-A $=29^{\circ} 08.707^{\prime} \mathrm{N}$ by $89^{\circ} 18.515^{\prime} \mathrm{W}$

WB08-A $=29^{\circ} 09.580^{\prime} \mathrm{N}$ by $89^{\circ} 18.417^{\prime} \mathrm{W}$

WB09-A = 29 $10.396^{\prime} \mathrm{N}$ by $89^{\circ} 18.220^{\prime} \mathrm{W}$

WB10-A = 29 $11.334^{\prime} \mathrm{N}$ by $89^{\circ} 18.187^{\prime} \mathrm{W}$

WB12-A = 29 $10.751^{\prime}$ N by $89^{\circ} 16.948^{\prime} \mathrm{W}$

WB15-A $=29^{\circ} 09.549^{\prime} \mathrm{N}$ by $89^{\circ} 16.940^{\prime} \mathrm{W}$

Core site coordinates where cores were obtained in April 2006:

$\mathrm{WB} 01-\mathrm{B}=29^{\circ} 12.585^{\prime} \mathrm{N}$ by $89^{\circ} 17.906^{\prime} \mathrm{W}$

WB02-B $=29^{\circ} 12.116^{\prime} \mathrm{N}$ by $89^{\circ} 18.101^{\prime} \mathrm{W}$

WB03-B $=29^{\circ} 11.696^{\prime} \mathrm{N}$ by $89^{\circ} 19.062^{\prime} \mathrm{W}$

WB04-B $=29^{\circ} 10.989^{\prime} \mathrm{N}$ by $89^{\circ} 19.514^{\prime} \mathrm{W}$

WB05-B $=29^{\circ} 10.250^{\prime} \mathrm{N}$ by $89^{\circ} 19.808^{\prime} \mathrm{W}$

WB06-B $=29^{\circ} 07.939^{\prime} \mathrm{N}$ by $89^{\circ} 19.454^{\prime} \mathrm{W}$

WB07-B $=29^{\circ} 08.696^{\prime} \mathrm{N}$ by $89^{\circ} 18.512^{\prime} \mathrm{W}$

WB08-B $=29^{\circ} 09.583^{\prime} \mathrm{N}$ by $89^{\circ} 18.409^{\prime} \mathrm{W}$

$\mathrm{WB} 09-\mathrm{B}=29^{\circ} 10.392^{\prime} \mathrm{N}$ by $89^{\circ} 18.219^{\prime} \mathrm{W}$

WB10-B $=29^{\circ} 11.330^{\prime} \mathrm{N}$ by $89^{\circ} 18.221^{\prime} \mathrm{W}$

$\mathrm{WB} 12-\mathrm{B}=29^{\circ} 10.750^{\prime} \mathrm{N}$ by $89^{\circ} 16.961^{\prime} \mathrm{W}$

$\mathrm{WB} 15-\mathrm{B}=29^{\circ} 09.551^{\prime} \mathrm{N}$ by $89^{\circ} 16.940^{\prime} \mathrm{W}$

$\mathrm{WB} 17-\mathrm{B}=29^{\circ} 07.939^{\prime} \mathrm{N}$ by $89^{\circ} 17.464^{\prime} \mathrm{W}$ 


\section{$\underline{\text { Sub-appendix } C}$}

Important web links associated with project

1) Nortek Aquadopp ADCP specifications:

- http://www.nortekusa.com/brochures/AquadoppProfiler.pdf

- Also in "Instrument Specifications" directory on data disk

Filename: AquadoppProfiler.pdf

2) Nortek Aquadopp ADCP manual:

- Found in "Manuals" directory on data disk

Filename: Aquadopp\%20profiler.pdf

3) YSI 6600 Sonde specifications:

- http://www.ysi.com/extranet/EPGKL.nsf/447554deba0f52f2852569f500696b21/8db4236 9ec1b6e3a85256cef00562ec6!OpenDocument

- Also in "Instrument Specifications" directory on data disk

Filename: YSI_6600_sonde_specs.pdf

4) YSI 6600 Sonde manual:

- http://www.ysi.com/extranet/EPGKL.nsf/447554deba0f52f2852569f500696b21/90a0378 150c2d2dd85256a1f0073f295! OpenDocument

- Also in "Manuals" directory on data disk

Filename: YSI_6600_manual.pdf

5) CSI Wave/Turbidity Gauge Specifications:

Pressure Sensor - Paroscientific, Inc

- http://www.paroscientific.com/pdf/2000.pdf

- Also in "Instrument Specifications" directory on data disk

Filename: Paroscientific_specs.pdf

Turbidity Sensor - McVan Instruments NEP9500

- http://www.mcvan.com/acrobat/NEP9000.pdf

- Also in "Instrument Specifications" directory on data disk

Filename: McVan_NEP9000_specs.pdf

Onset Computer Corp - Tattle-tale model 8V2

- http://www.onsetcomp.com/Products/Product_Pages/Tattletale_pages/TT8.html

6) RD Instruments - Workhorse Monitor $1200 \mathrm{kHz}$

- http://www.rdinstruments.com/pdfs/datasheets/workhorse_monitor_ds_lr.pdf

- Also in "Instrument Specifications" directory on data disk

Filename: workhorse_monitor_specs.pdf 


\section{$\underline{\text { Sub-appendix D }}$}

Photo \#1 - Instrument site at diversion cut

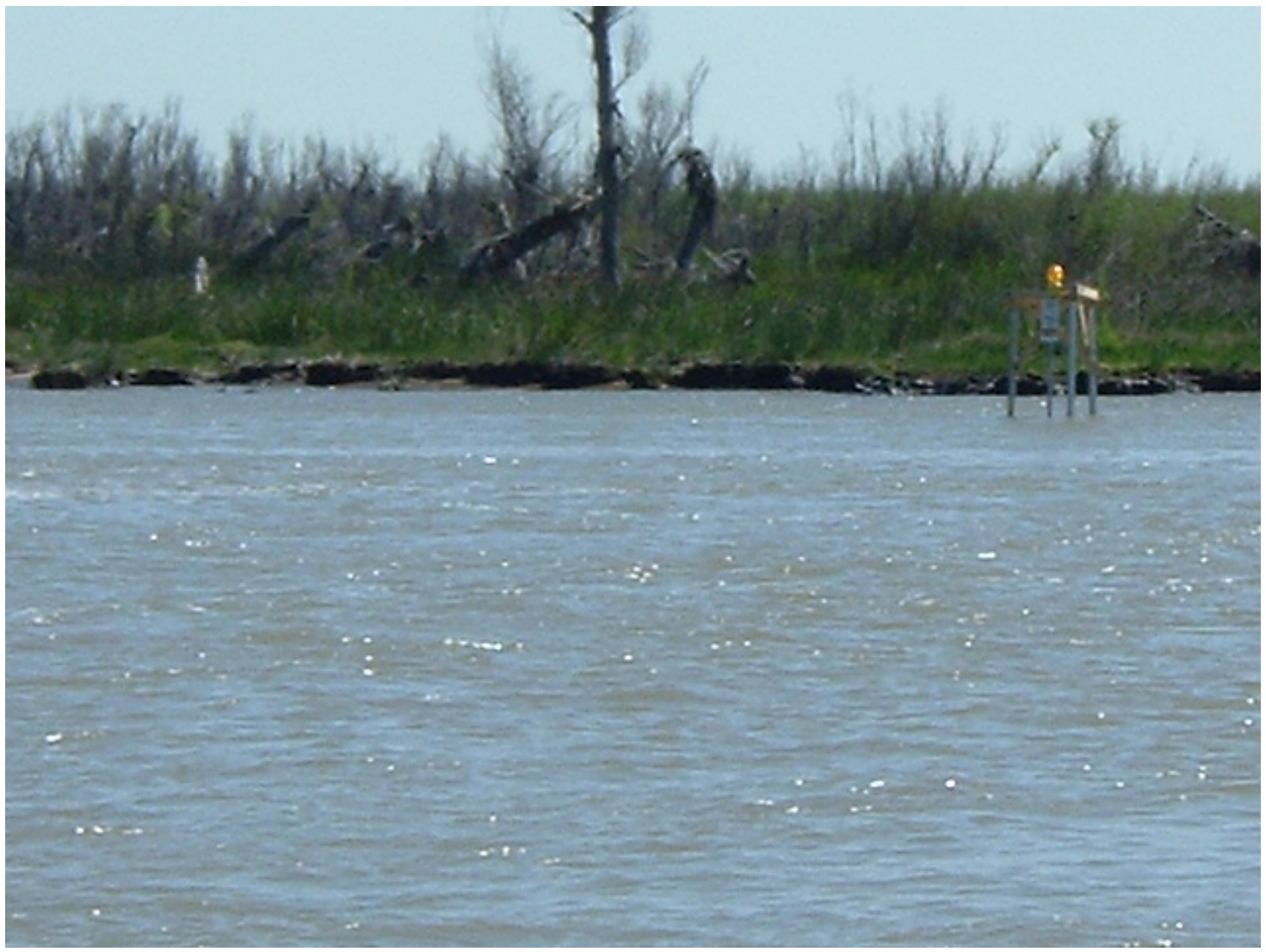


Photo \#2 - Instrument platform from north side of diversion cut

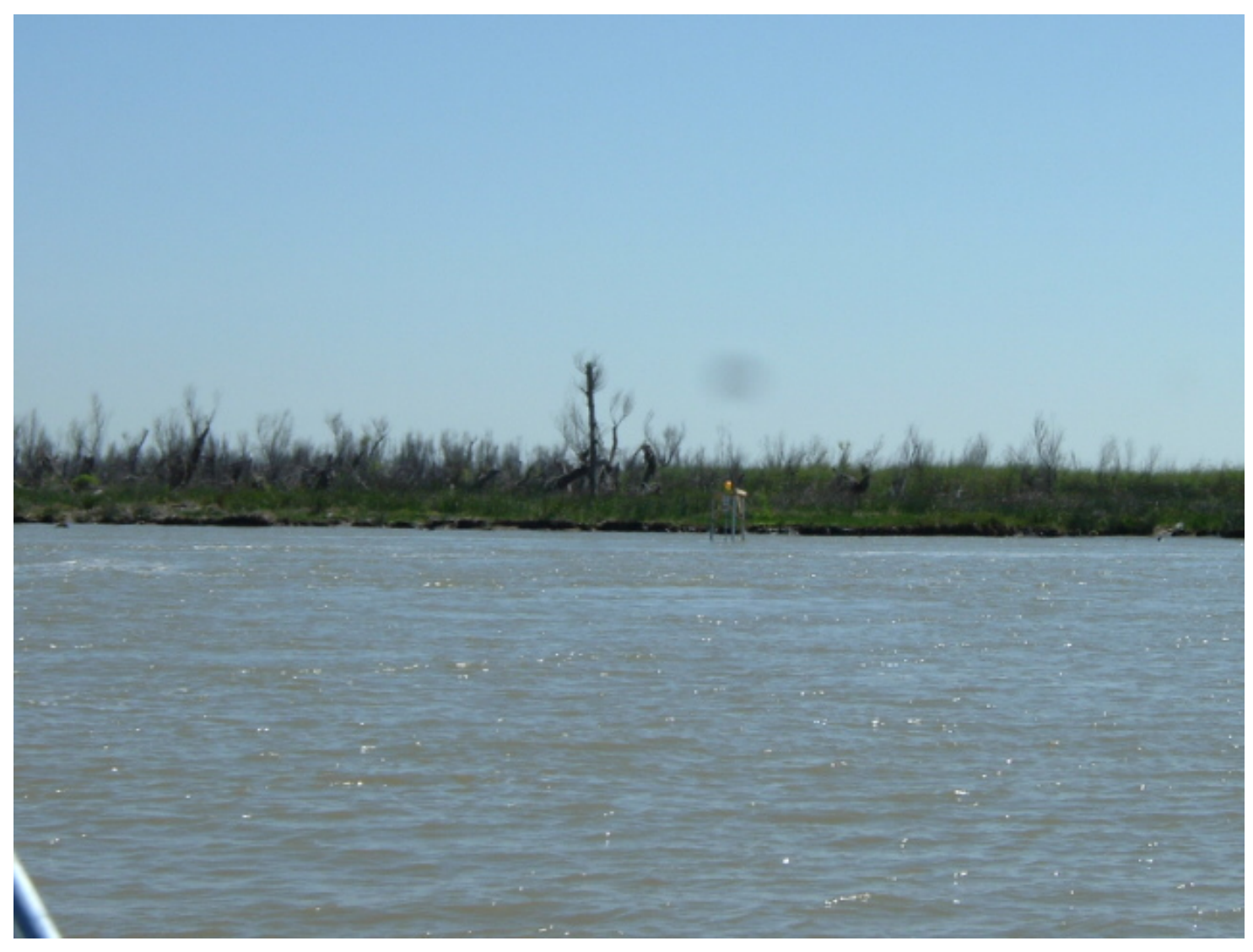


Photo \#3 - Profiling ADCP setup on bow of vessel

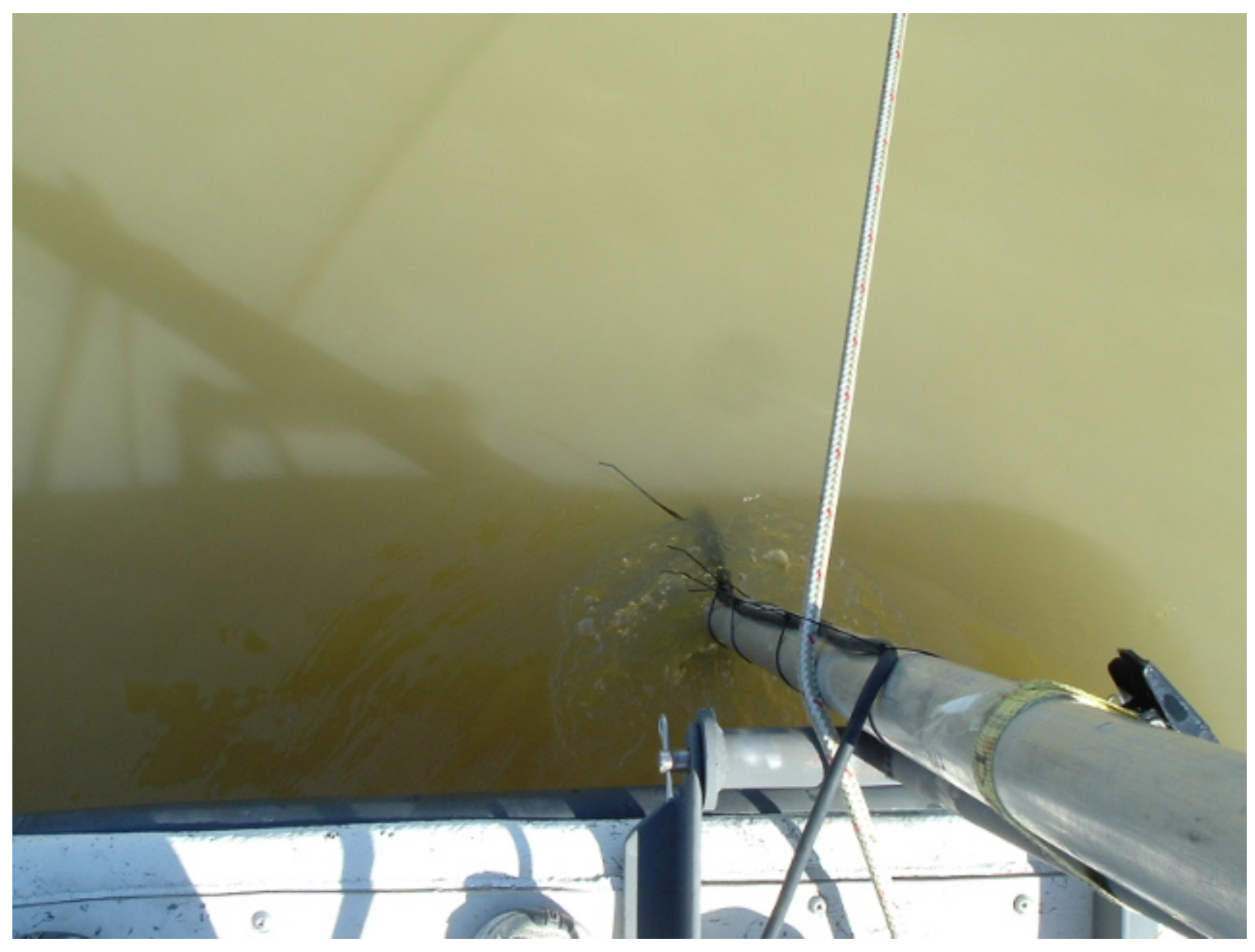


Photo \#4 - Profiling ADCP support on bow of vessel

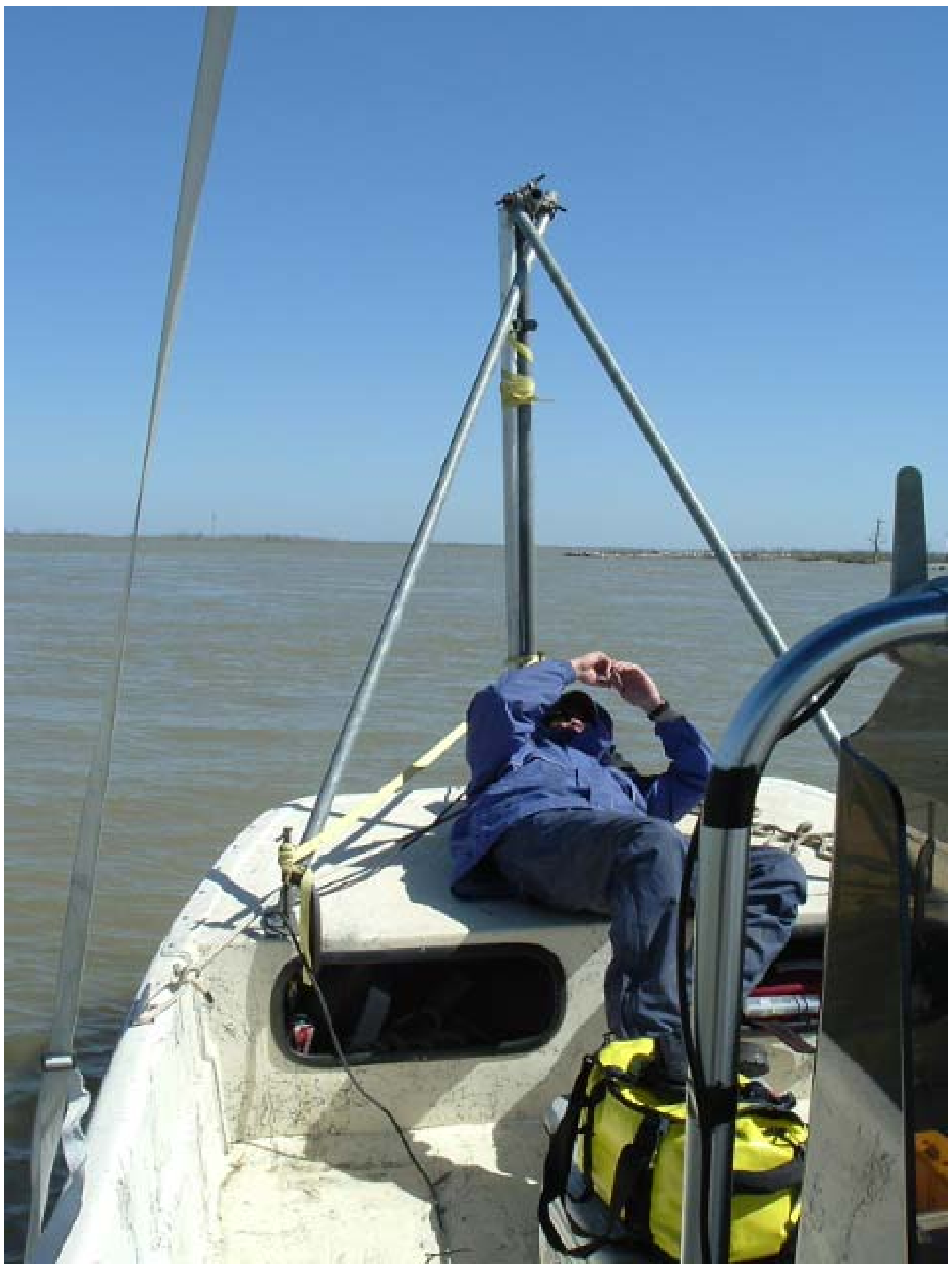


Photo \#5 - Data collection screen of profiling ADCP

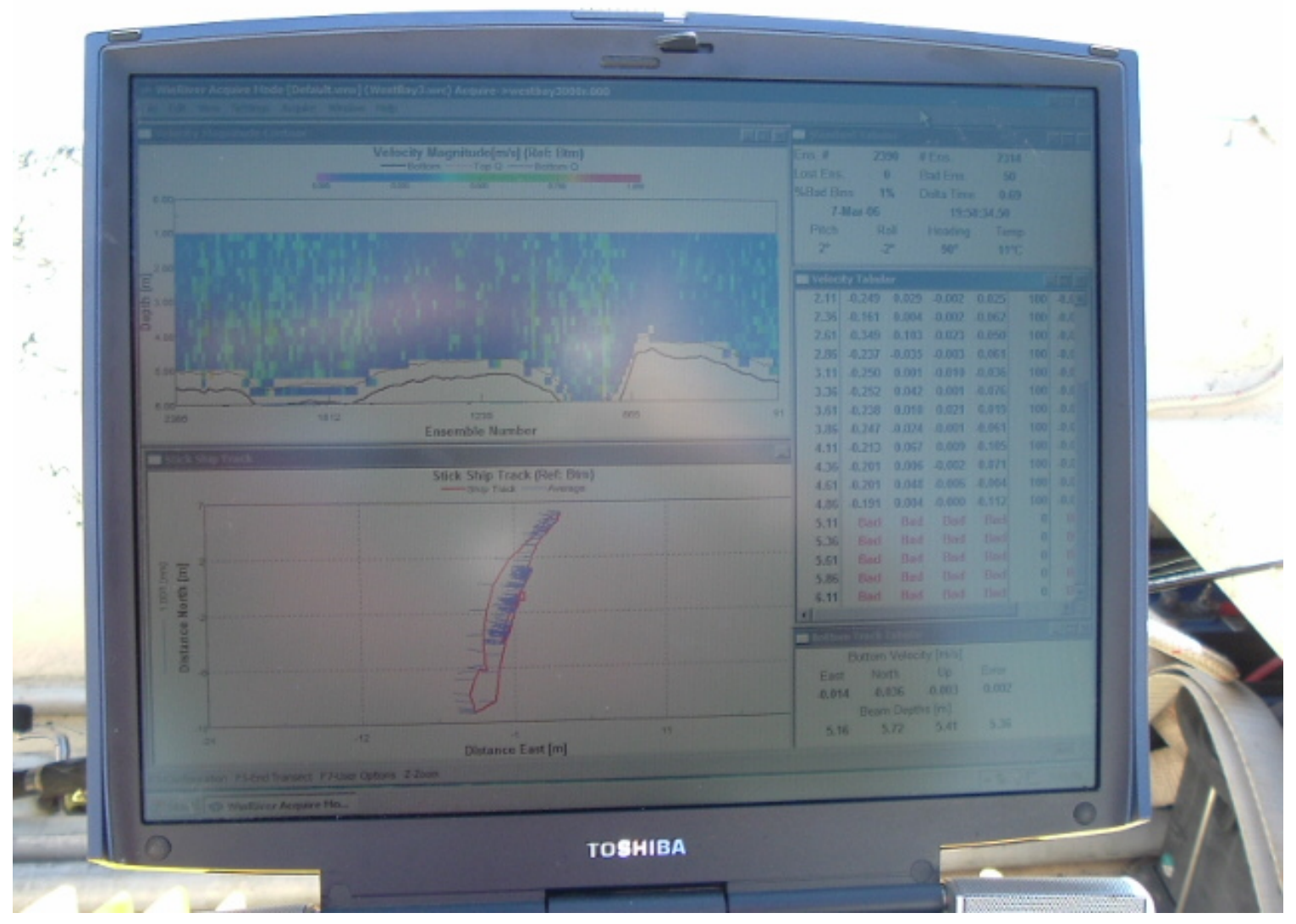




\section{$\underline{\text { Sub-appendix } E}$}

November 2005 survey plot lines

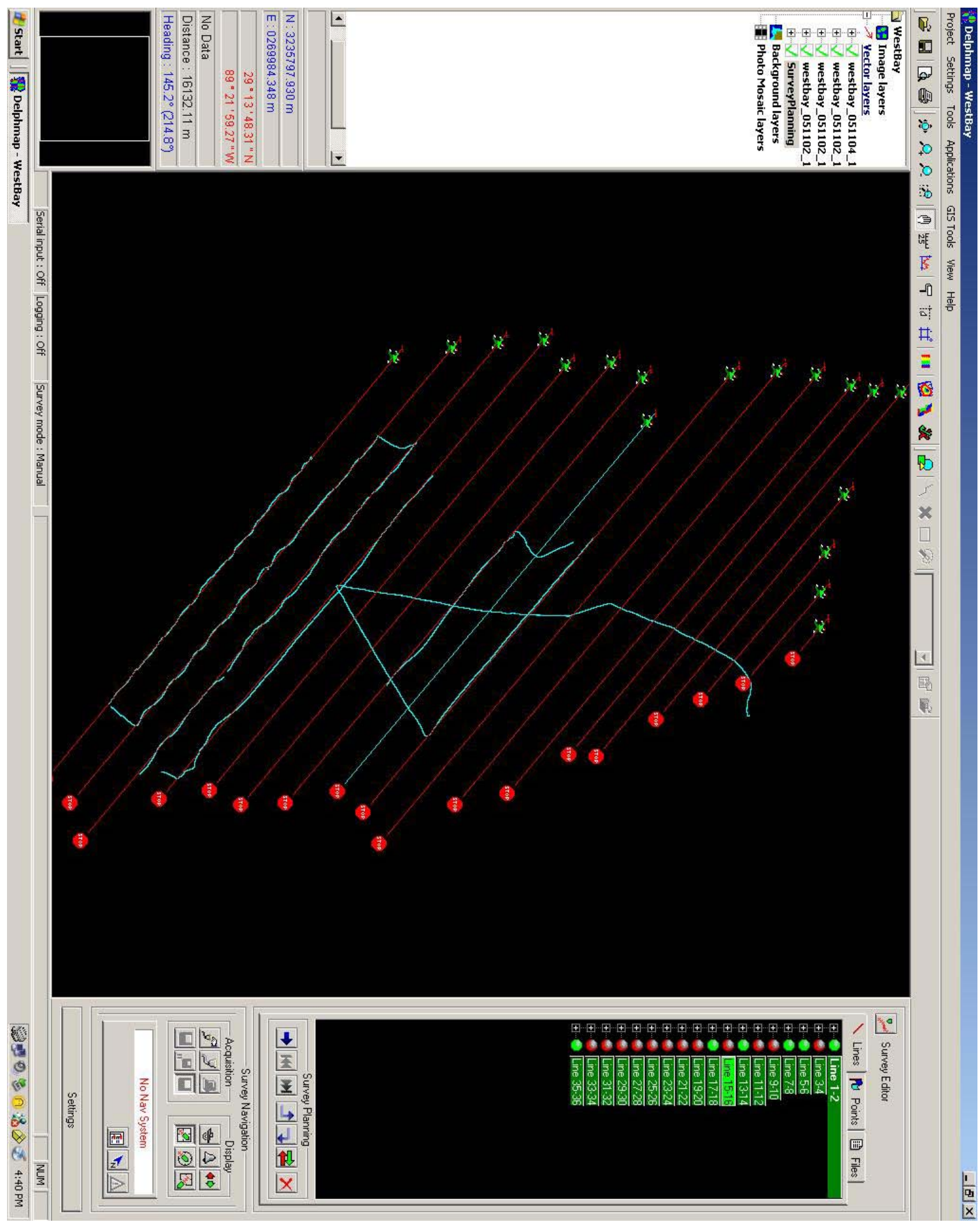




\section{$\underline{\text { Sub-appendix } F}$}

April 2006 survey line plot

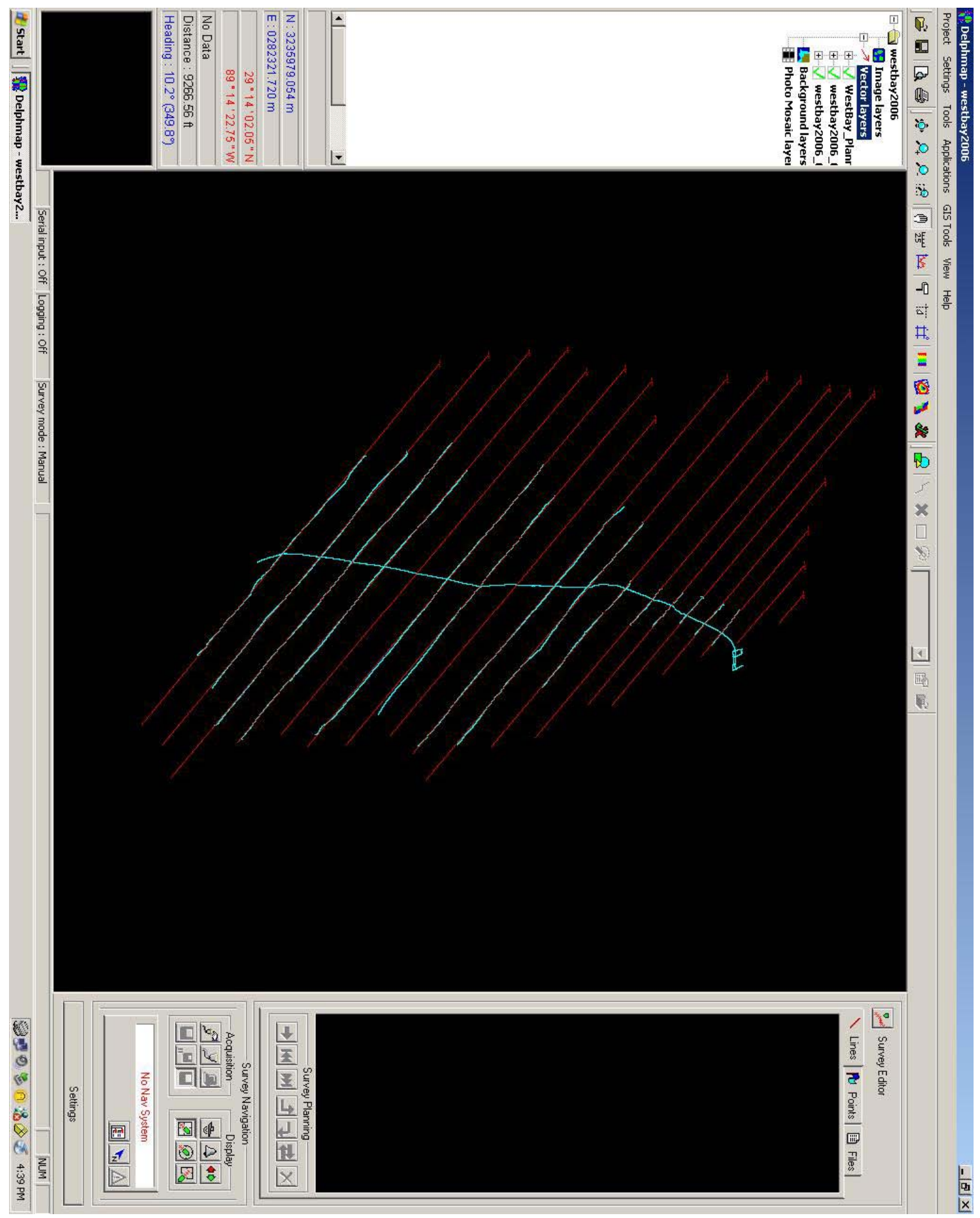




\section{$\underline{\text { Sub-appendix } G}$}

Diagram of Aquadopp in Diversion Cut.

Inset shows the relationship of the flows represented in the "WBcut01.v2" and "WBcut01.v3" velocity files.
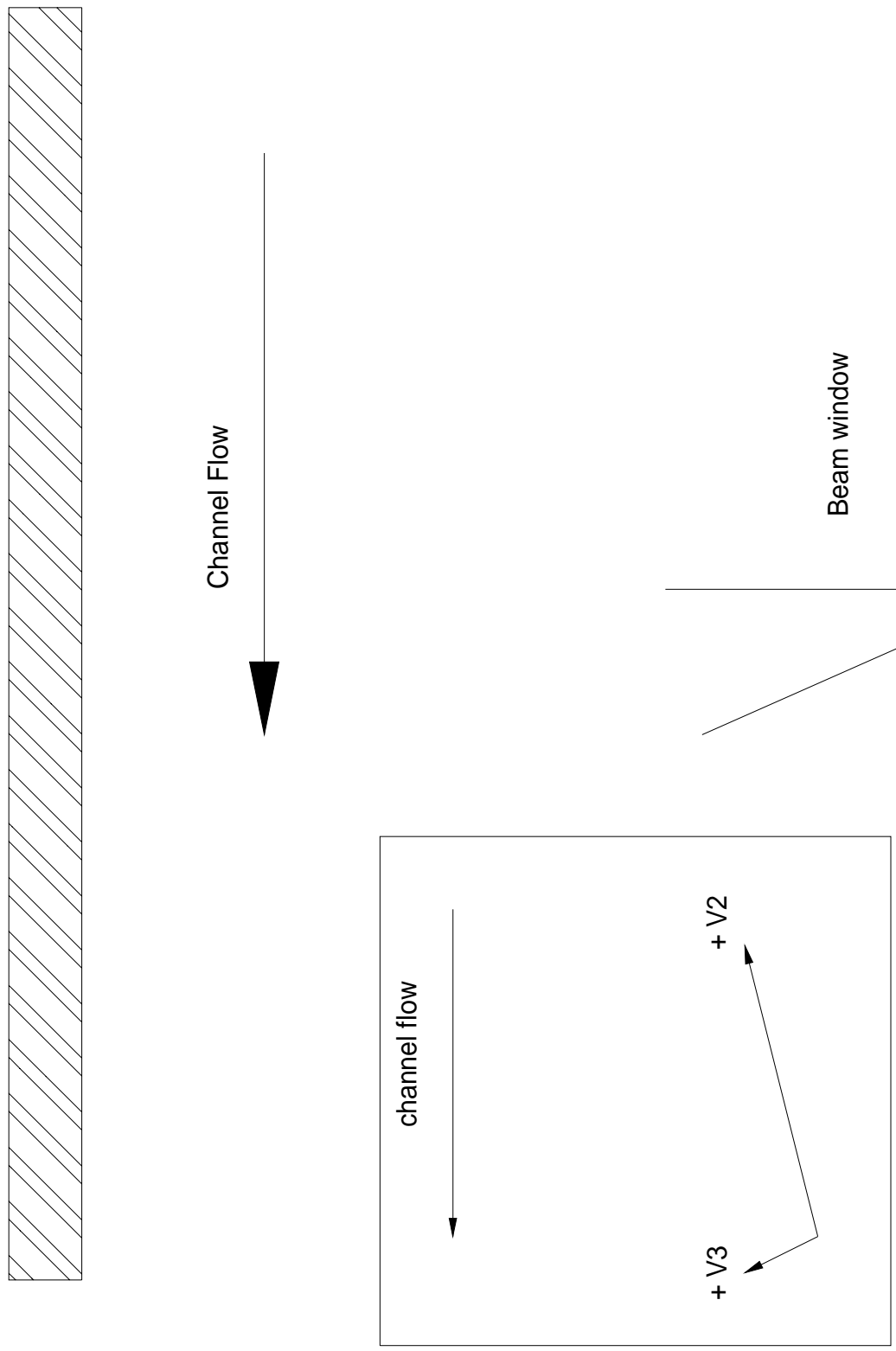
APPENDIX C

SURVEY MONUMENTS 


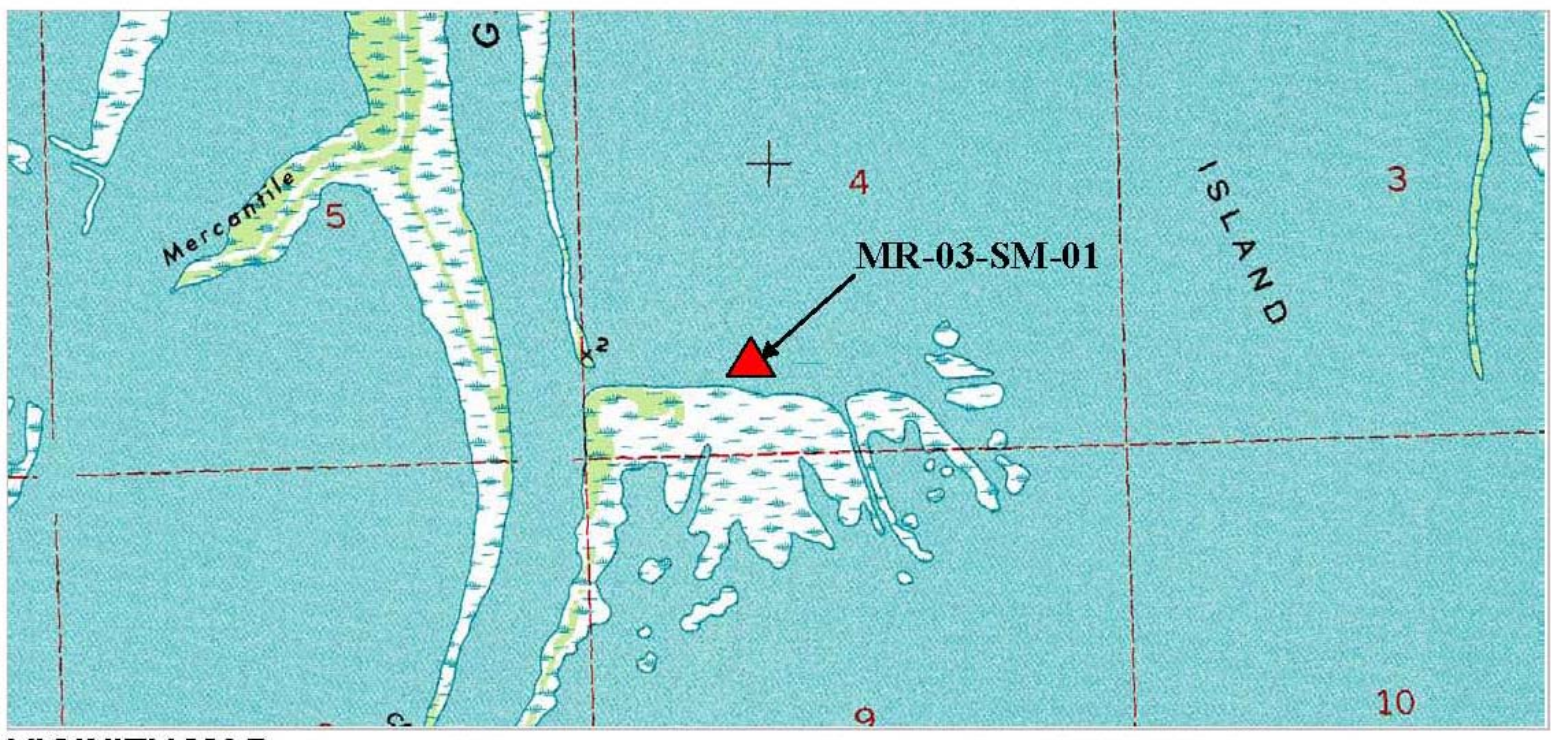

VICINITY MAP Scale: $1^{\prime \prime}=2000^{\prime}$

Reproduced from USC\&GS "Pilottown, La" Quadrangle

\section{Station Name: "MR-03-SM-01"}

Location: By boat from Venice, Louisiana, from the intersection of the Mississippi River and Grand Pass proceed in a southerly direction in Grand Pass for approximately 4.8 miles to the entrance of a channel to the left. Enter the channel and proceed in an easterly direction for approximately 1,884 feet. The Station is located 32 feet north of the bankline of the channel.

Monument Description: NGS style floating sleeve monument; datum point set on $9 / 16$ " stainless steel sectional rods driven 116 feet to refusal, set in sand filled 6" PVC pipe with access cover set in concrete.

Stamping: MR-03-SM-01

Installation Date: 2/12/03 Date of Survey: 2/12/03

Monument Established By: Morris P. Hebert, Inc.

For: Louisiana Department of Natural Resources, CRD

\section{Adjusted NAD 83 Geodetic Position}

Lat. $29^{\circ} 12,10.76863^{\prime \prime} \mathrm{N}$

Long. $89^{\circ} 19^{\prime} 59.65973^{\prime \prime} \mathrm{W}$

Adjusted NAD 83 Datum LSZ (1702) Feet

$\mathrm{N}=261,228.448$

$E=3,918,953.556$

\section{Adjusted NAVD88 Height}

Elevation $=2.52$ feet $(0.767$ Mtrs $)$

Geoid99 Height $=-23.854$ Mtrs . Ellipsoid Height $=-23.087$ Mtrs
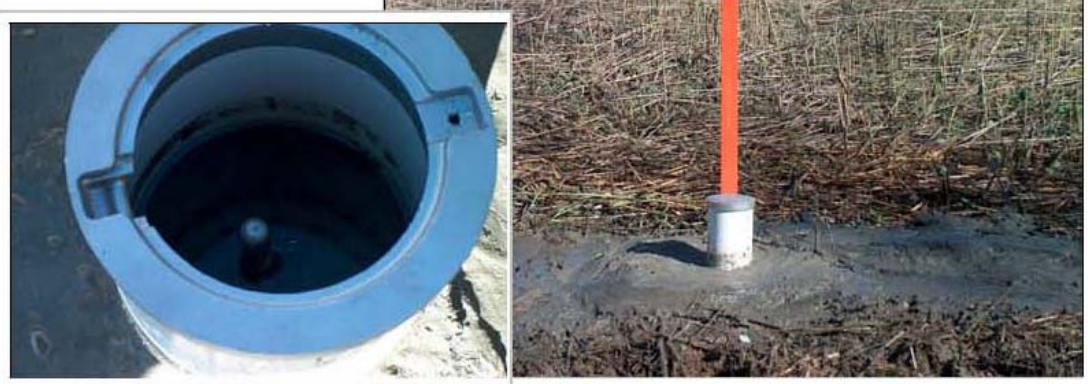

Adjusted Position Established for Louisiana Department of Natural Resources, Coastal Restoration Division 


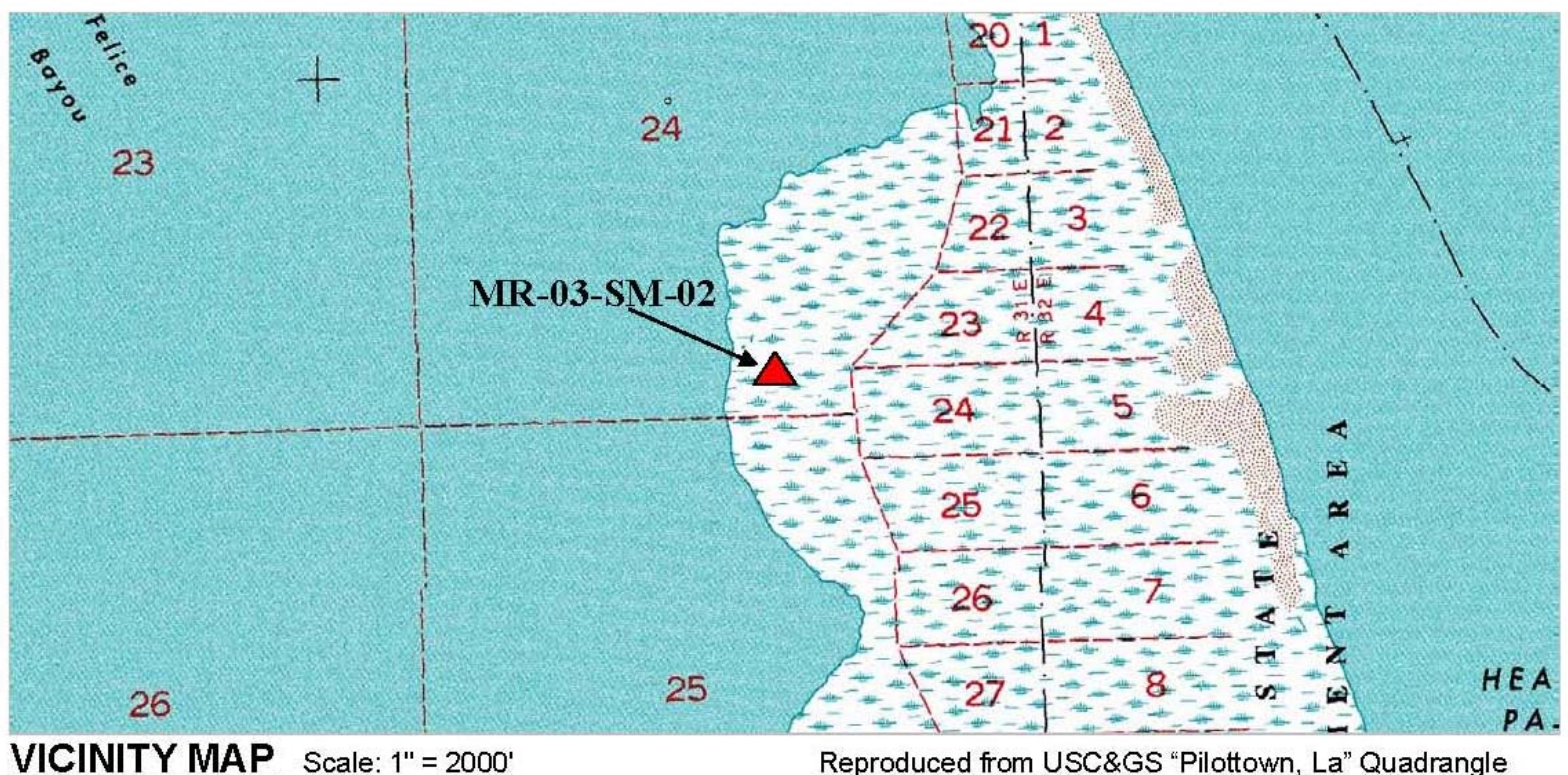

\section{Station Name: "MR-03-SM-02"}

Location: By airboat from Venice, Louisiana, from the intersection of the Mississippi River and Grand Pass proceed in a southerly direction in Grand Pass for approximately 4.8 miles to the entrance of a channel to the left. Enter the channel and proceed in an easterly direction for approximately 4,500 feet to the opening into a shallow bay. Then proceed in a southeasterly direction across the shallow bay for approximately 4.2 miles. The station is located 310 feet east of the bank line. Because of shallow water conditions this station is accessible by airboat only.

Monument Description: NGS style floating sleeve monument; datum point set on $9 / 16$ " stainless steel sectional rods driven 92 feet to refusal, set in sand filled 6" PVC pipe with access cover set in concrete.

Stamping: MR-03-SM-02

Installation Date: 2/12/03 Date of Survey: 2/12/03

Monument Established By: Morris P. Hebert, Inc.

For: Louisiana Department of Natura/Resources, CRD

Adjusted NAD 83 Geodetic Position

Lat. $29^{\circ} 09^{\prime} 31.37109^{\prime \prime} \mathrm{N}$

Long. $89^{\circ} 16^{\prime} 39.61113^{\prime \prime} \mathrm{W}$

Adjusted NAD 83 Datum LSZ (1702) Feet

$\mathrm{N}=245,443.27$

$E=3,936,969.55$

Adjusted NAVD88 Height Elevation $=3.72$ feet $(1.134$ Mtrs $)$

Geoid99 Height $=-23.806$ Mtrs. Ellipsoid Height $=\mathbf{- 2 2 . 6 7 2}$ Mtrs.
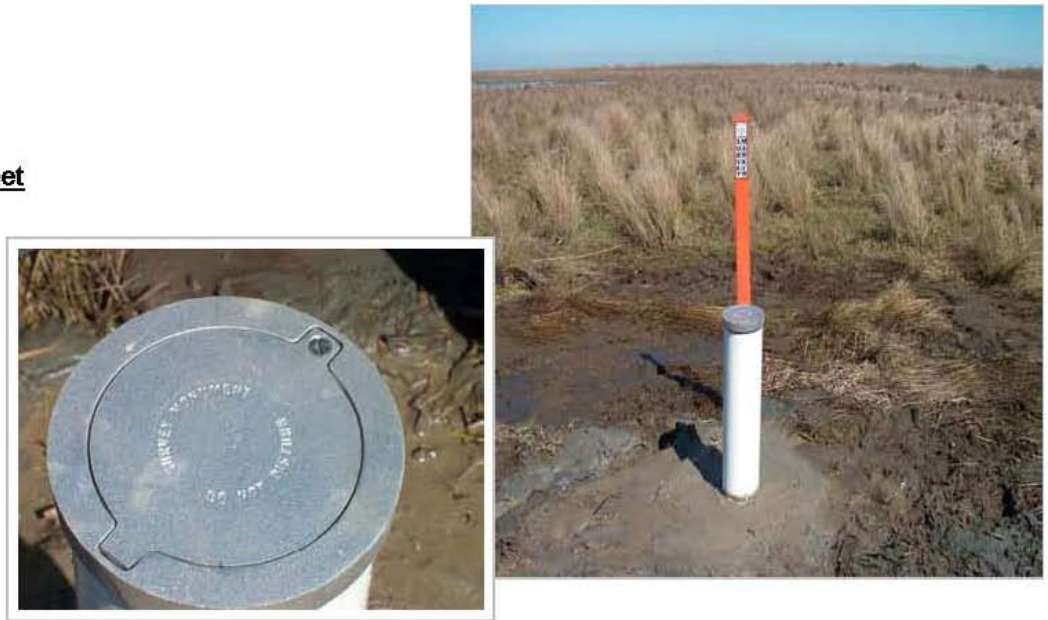

Adjusted Position Established for Louisiana Department of Natural Resources, Coastal Restoration Division 
APPENDIX D

GRAIN SIZE DATA 


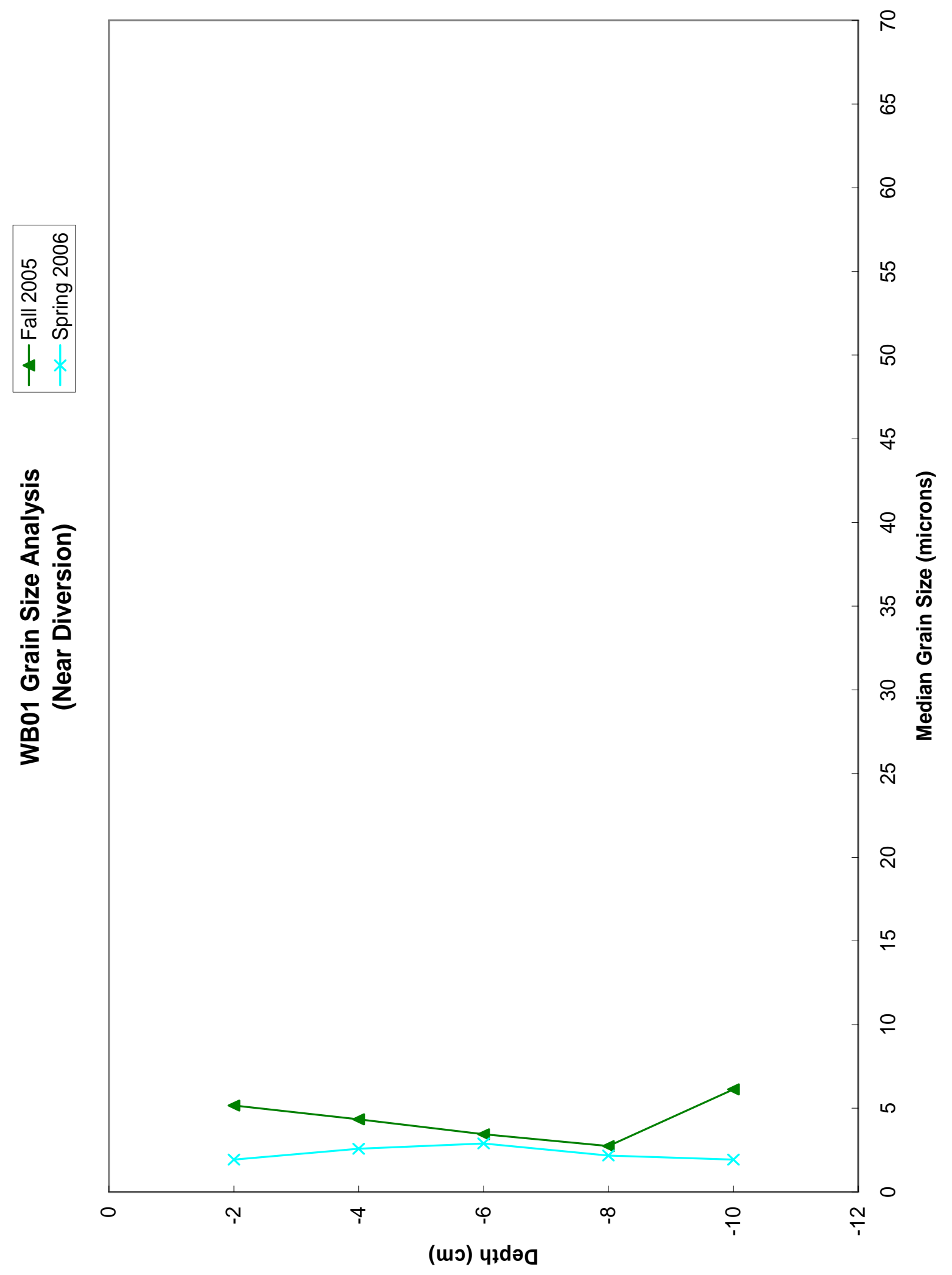




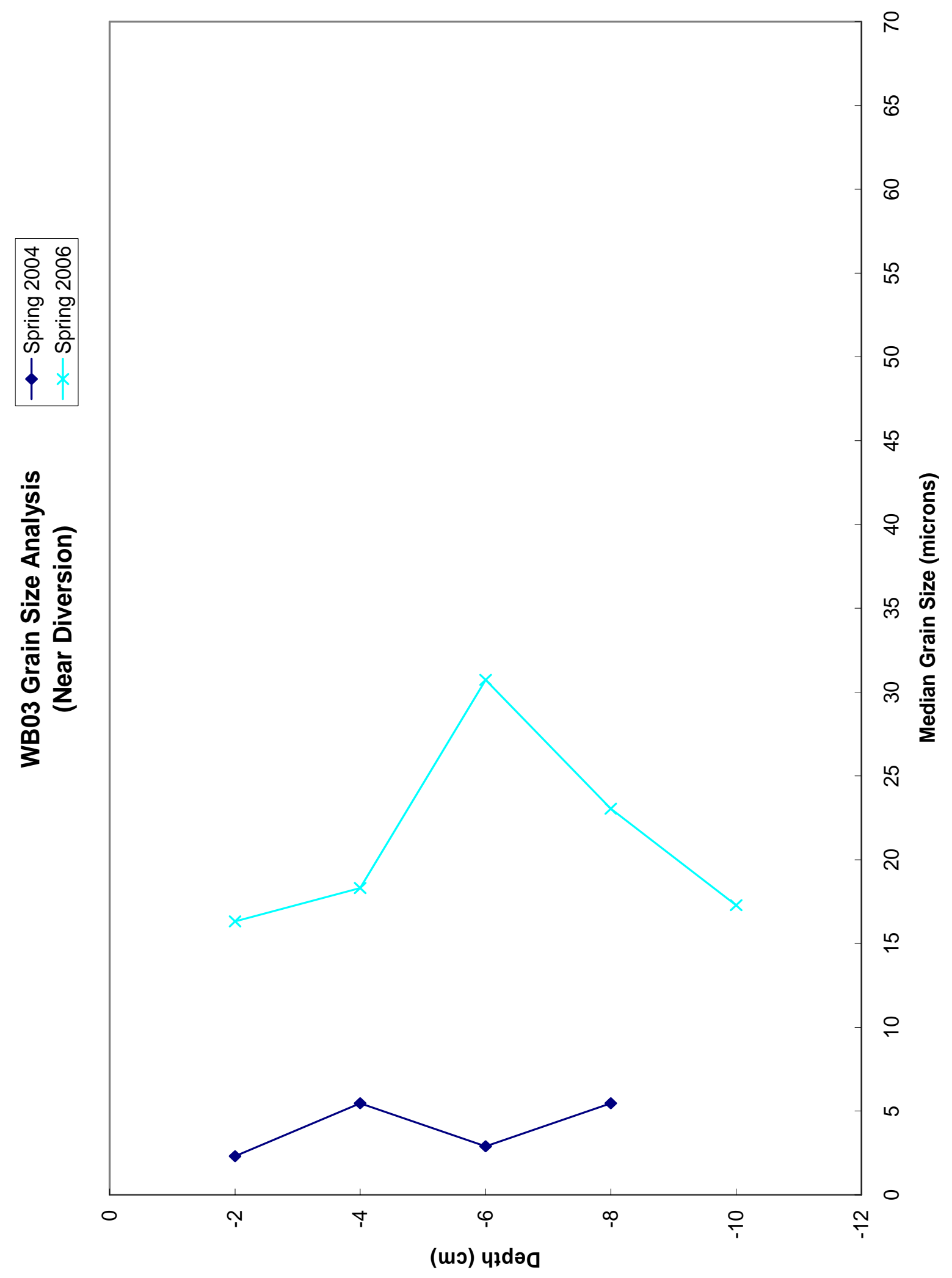




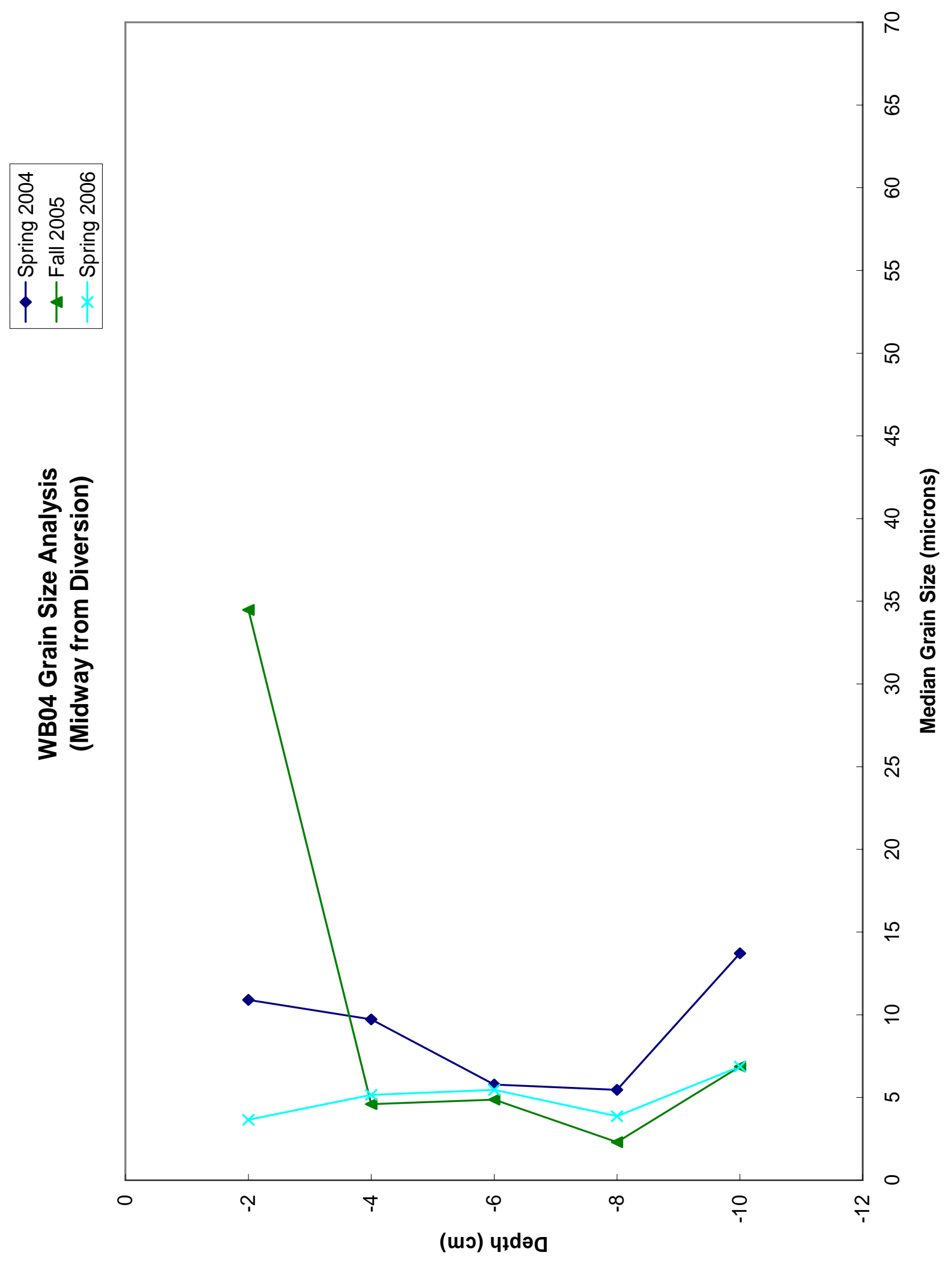




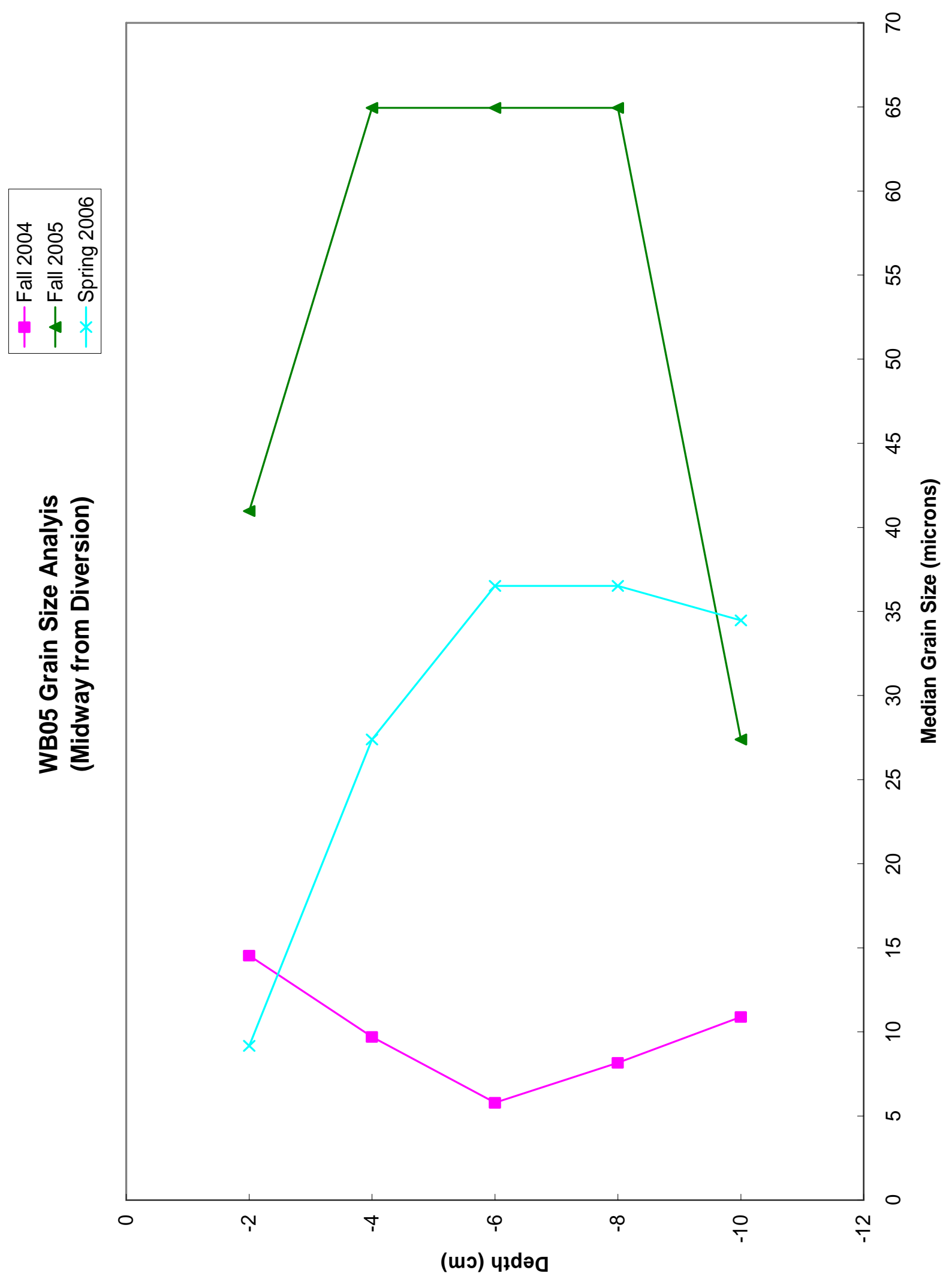




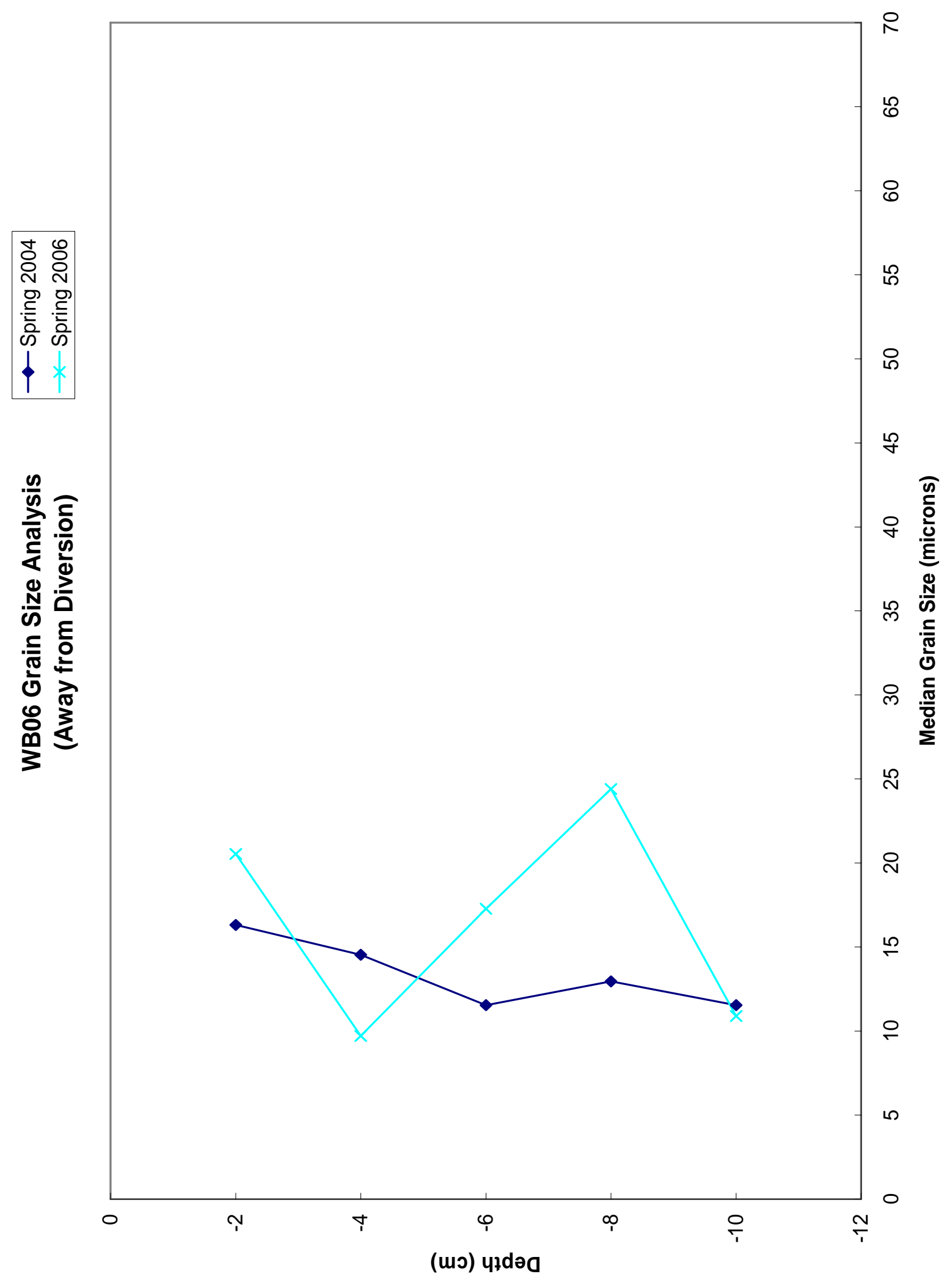




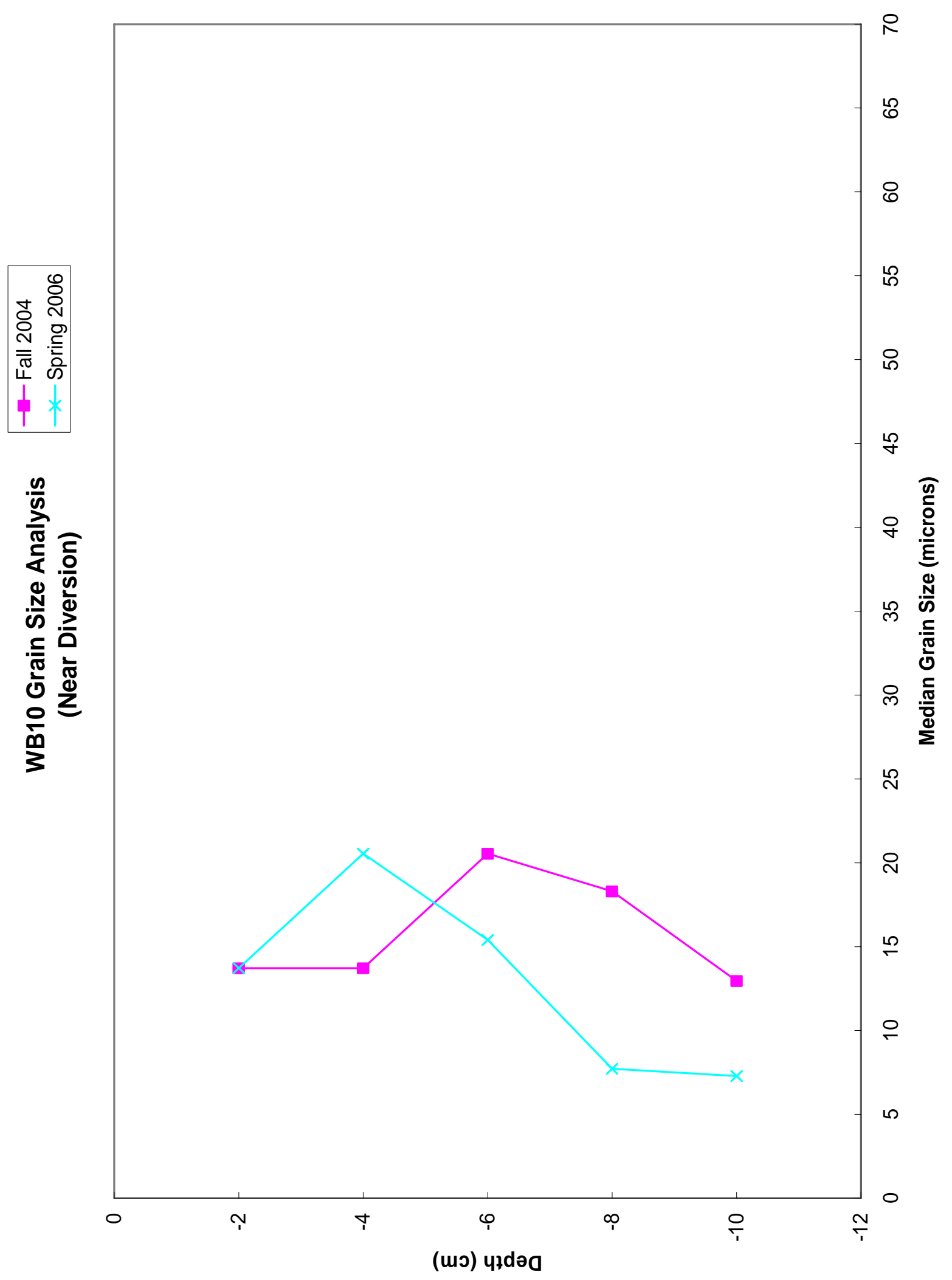




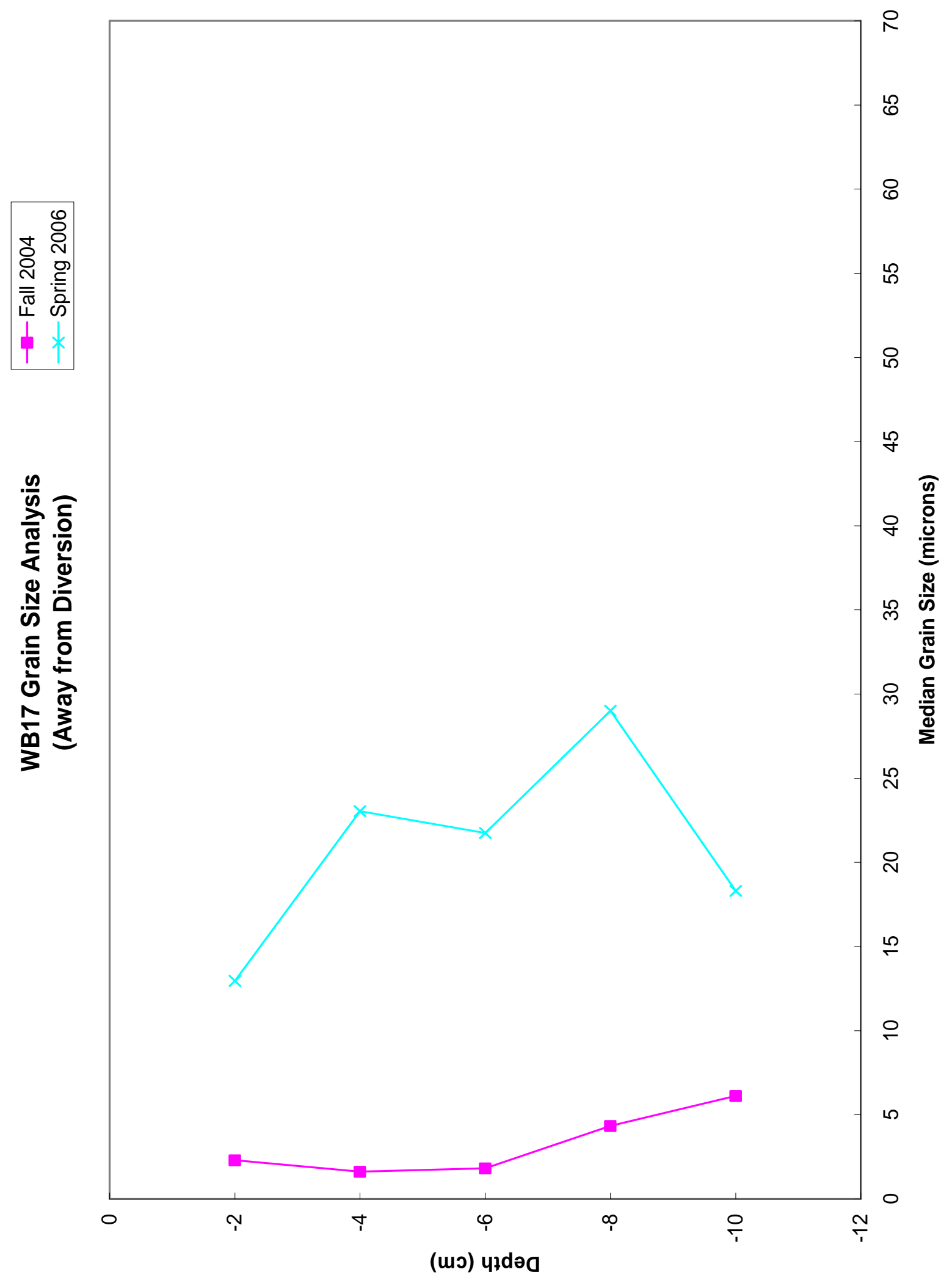




\section{APPENDIX E SURVEY CROSS SECTIONS}




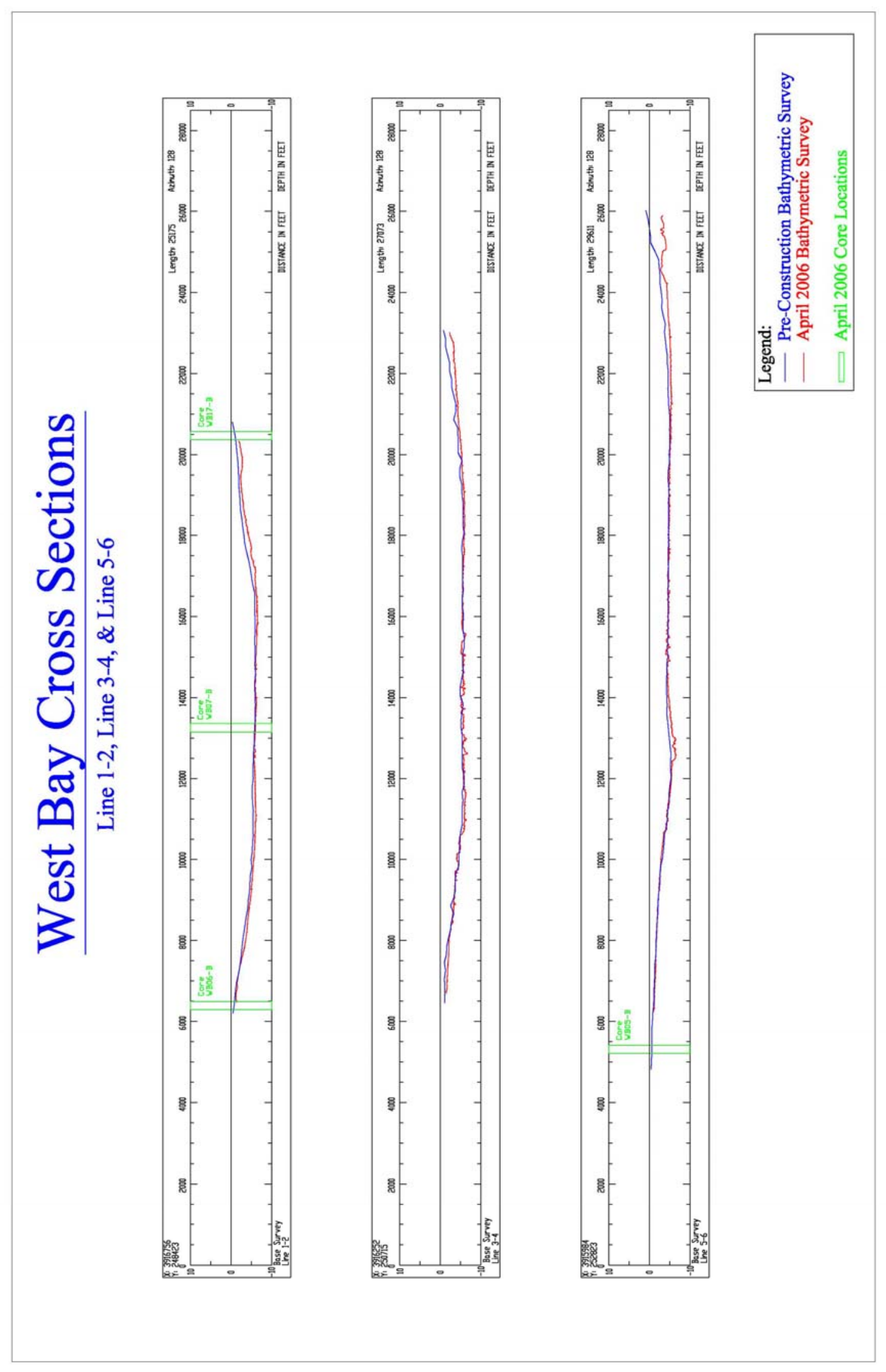




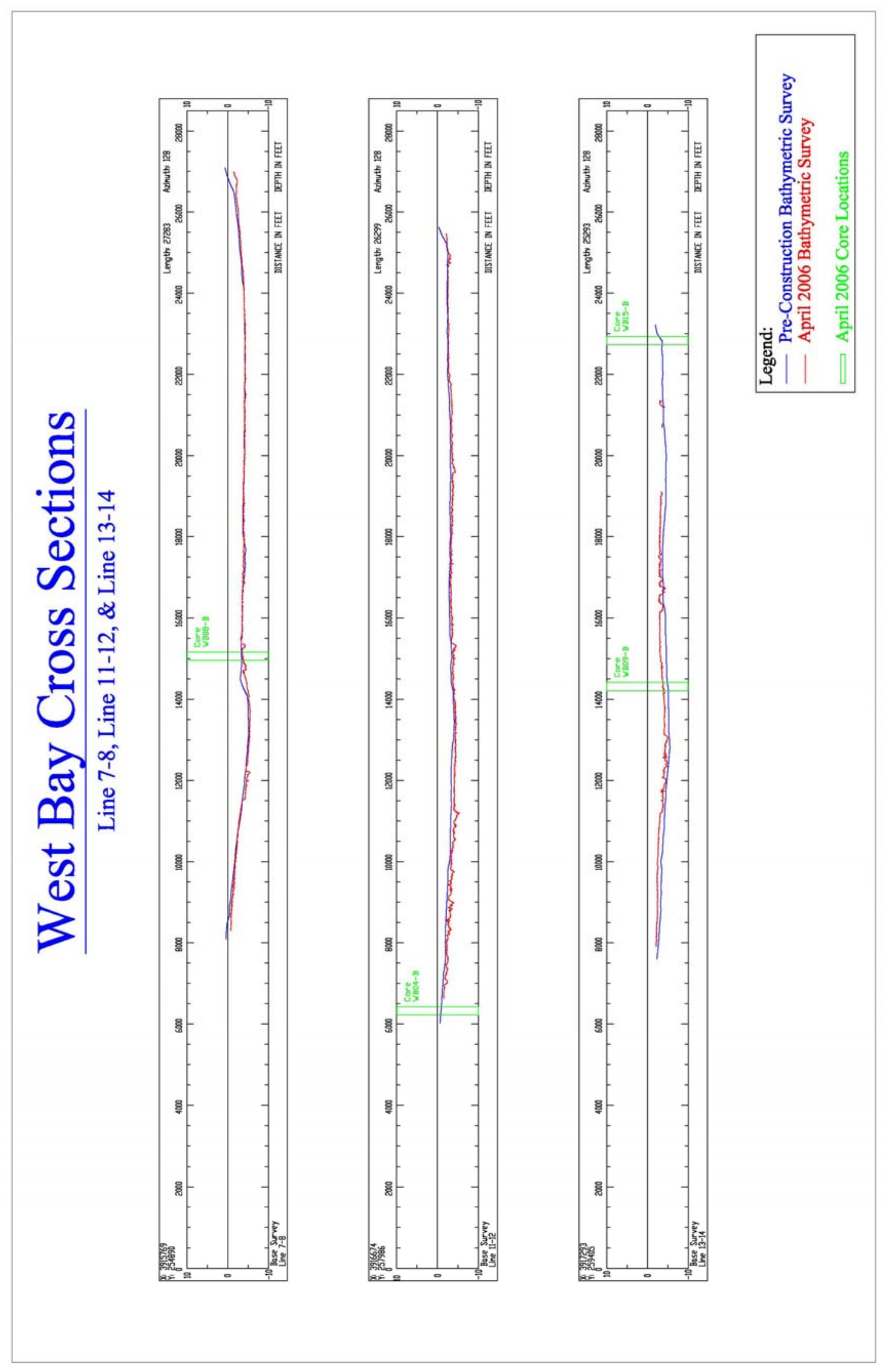




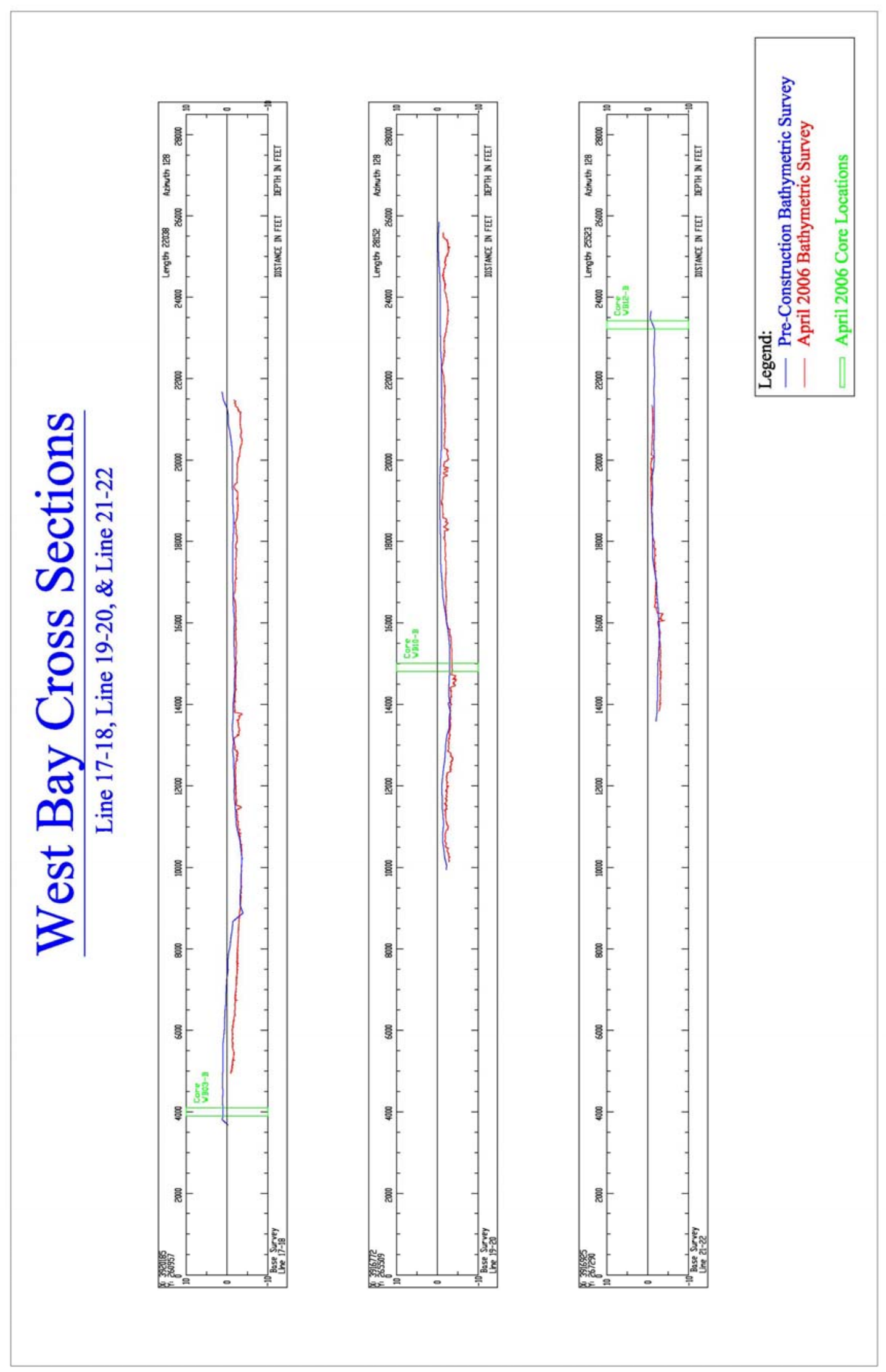




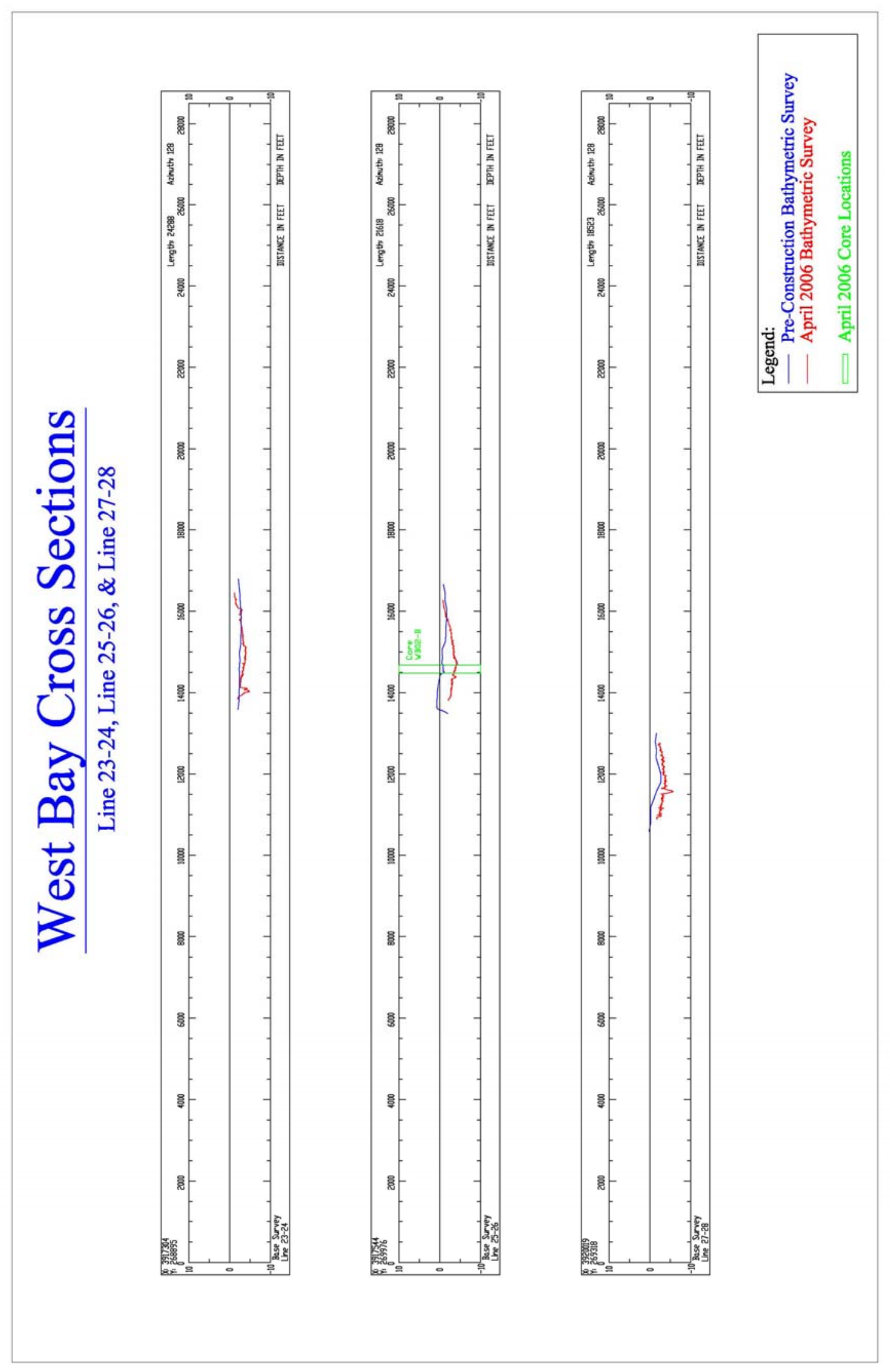




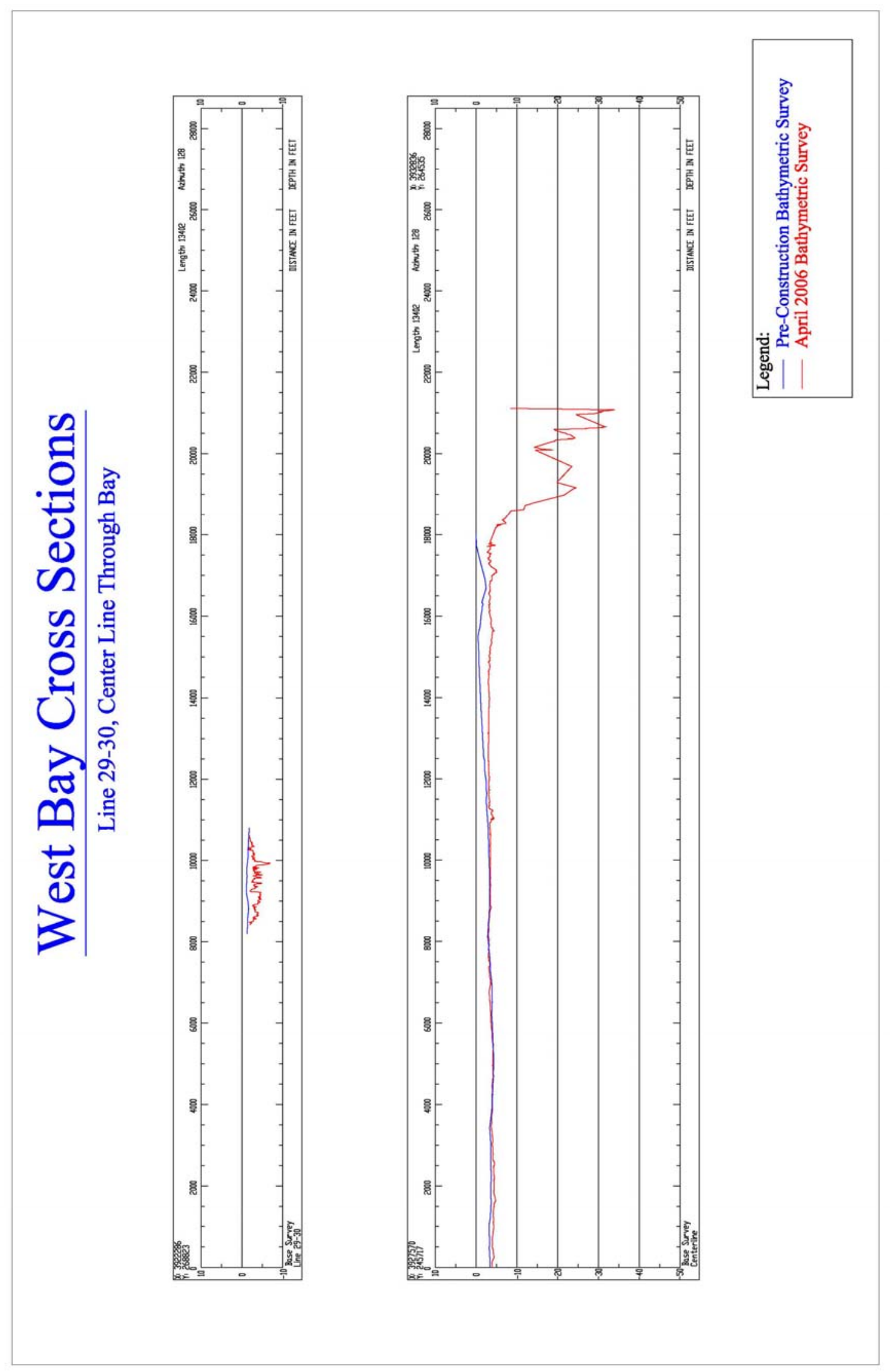




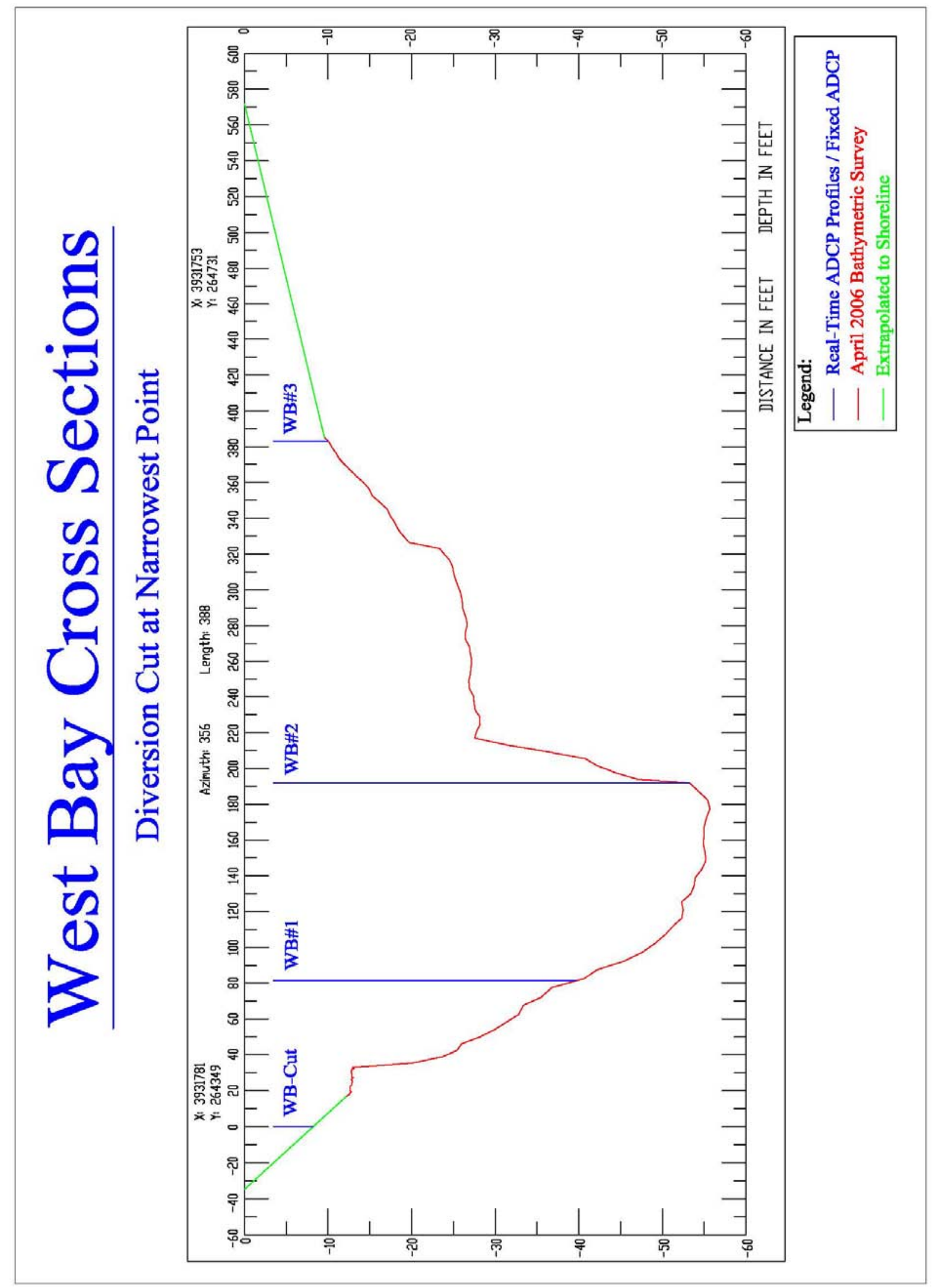




\section{APPENDIX F SPM CALCULATION SHEET}




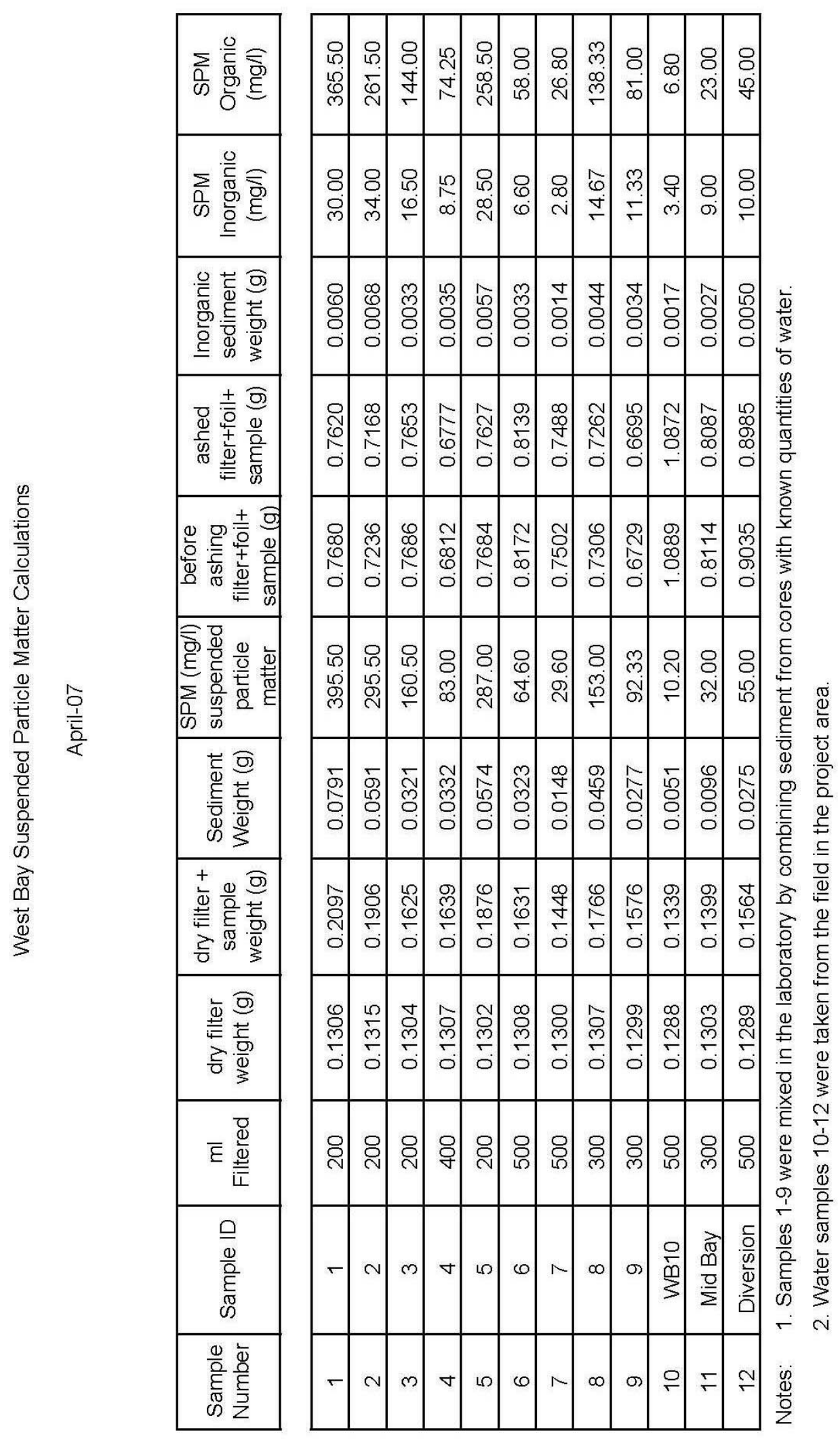




\section{APPENDIX G \\ WIND DATA}




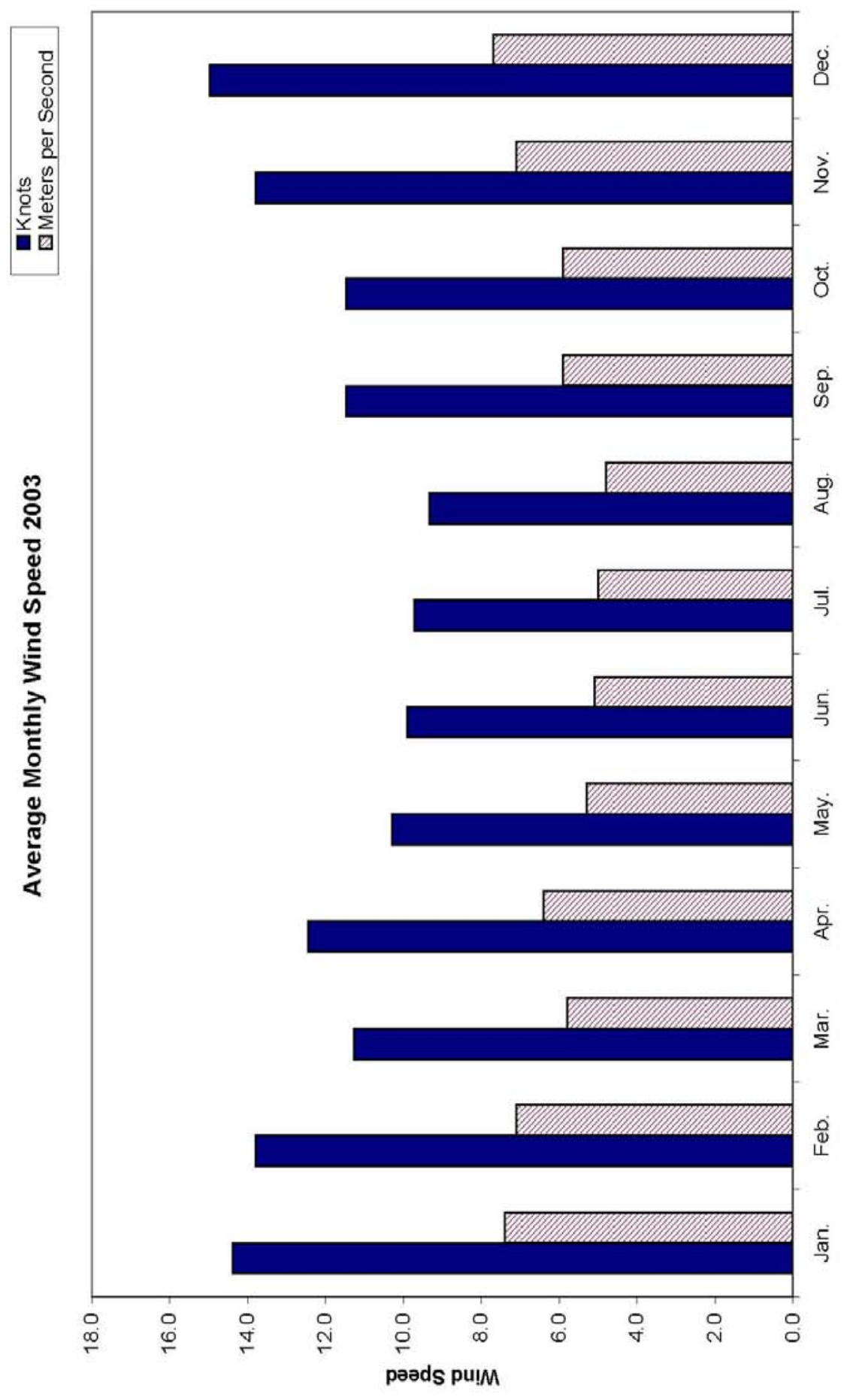




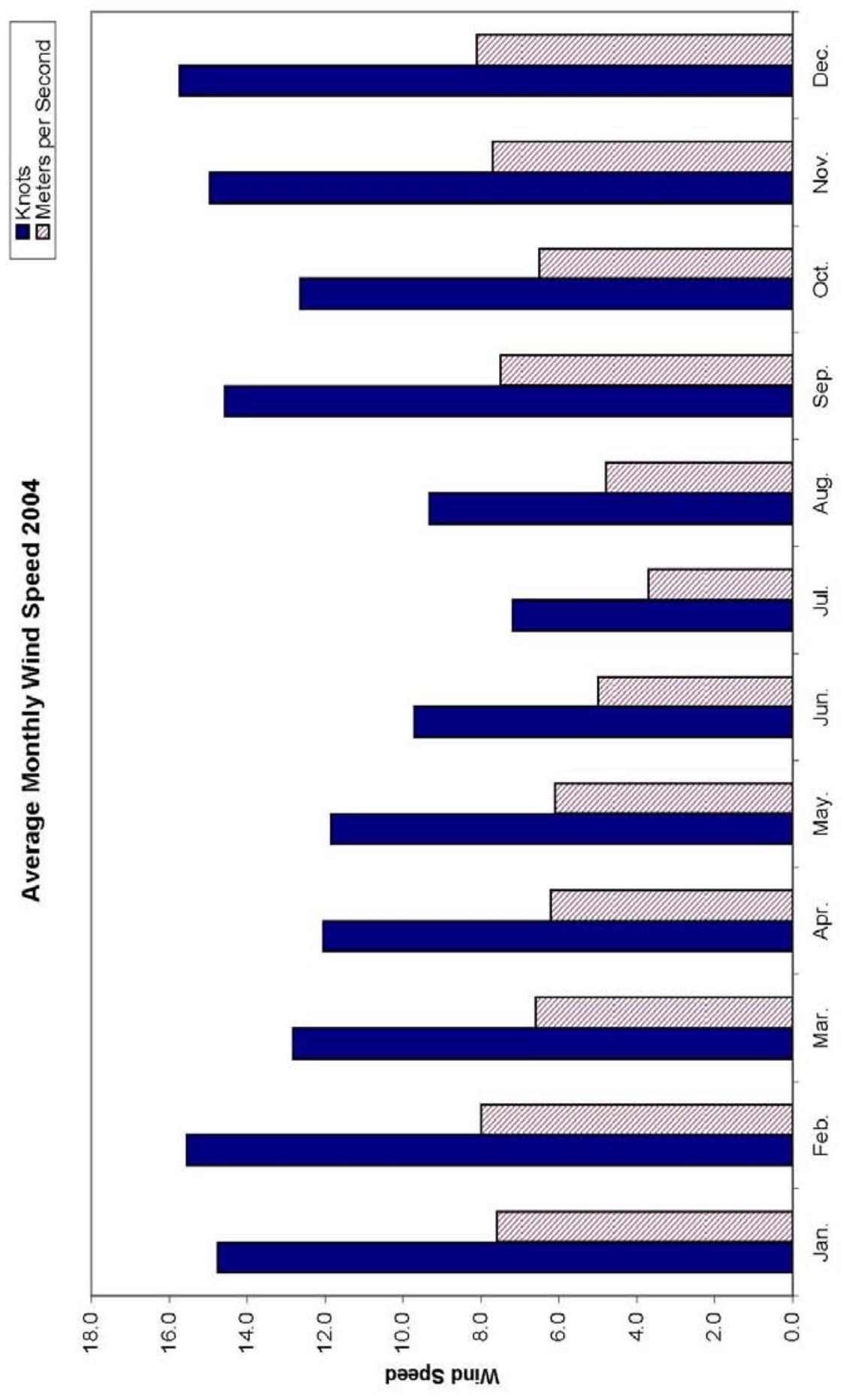




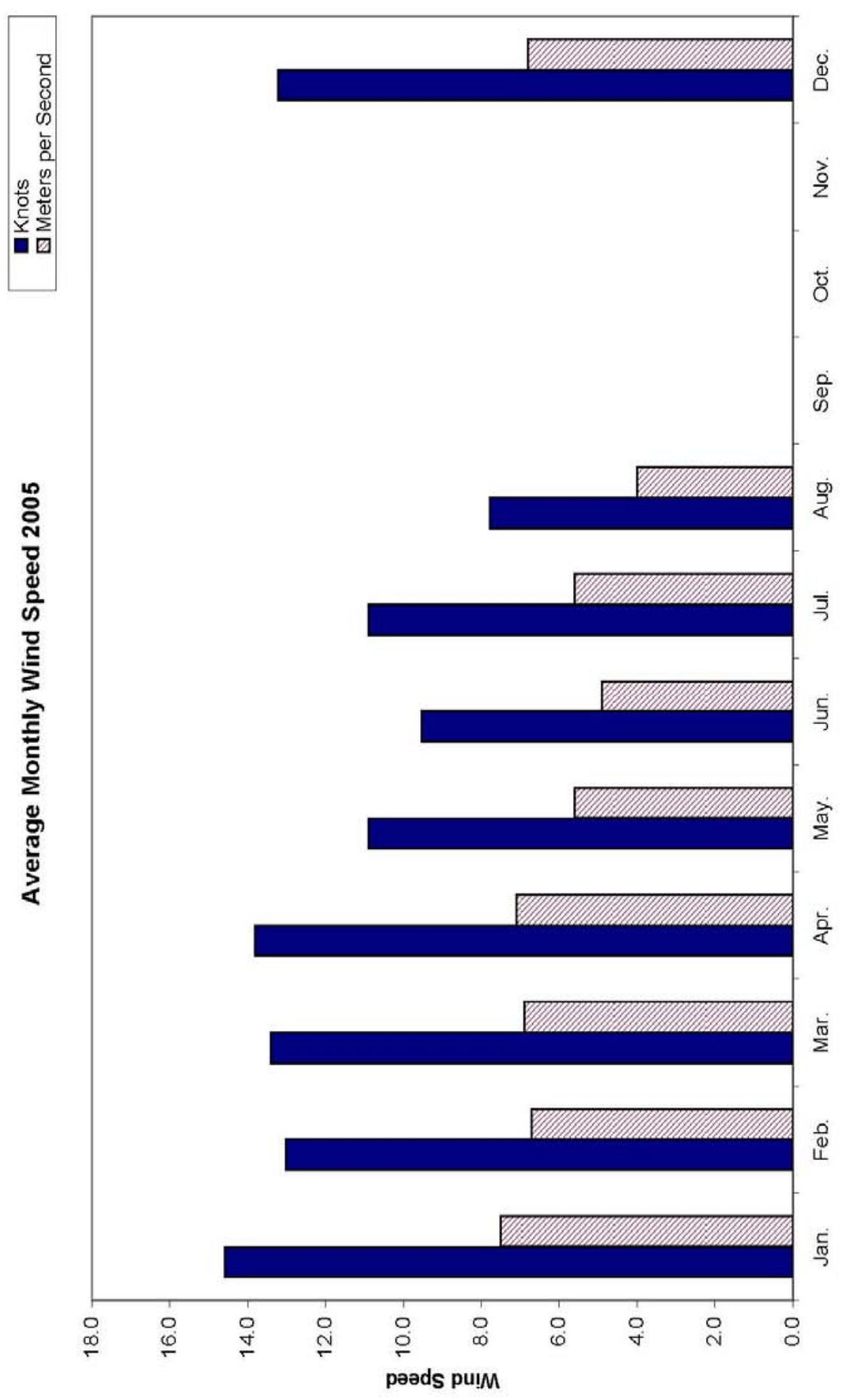




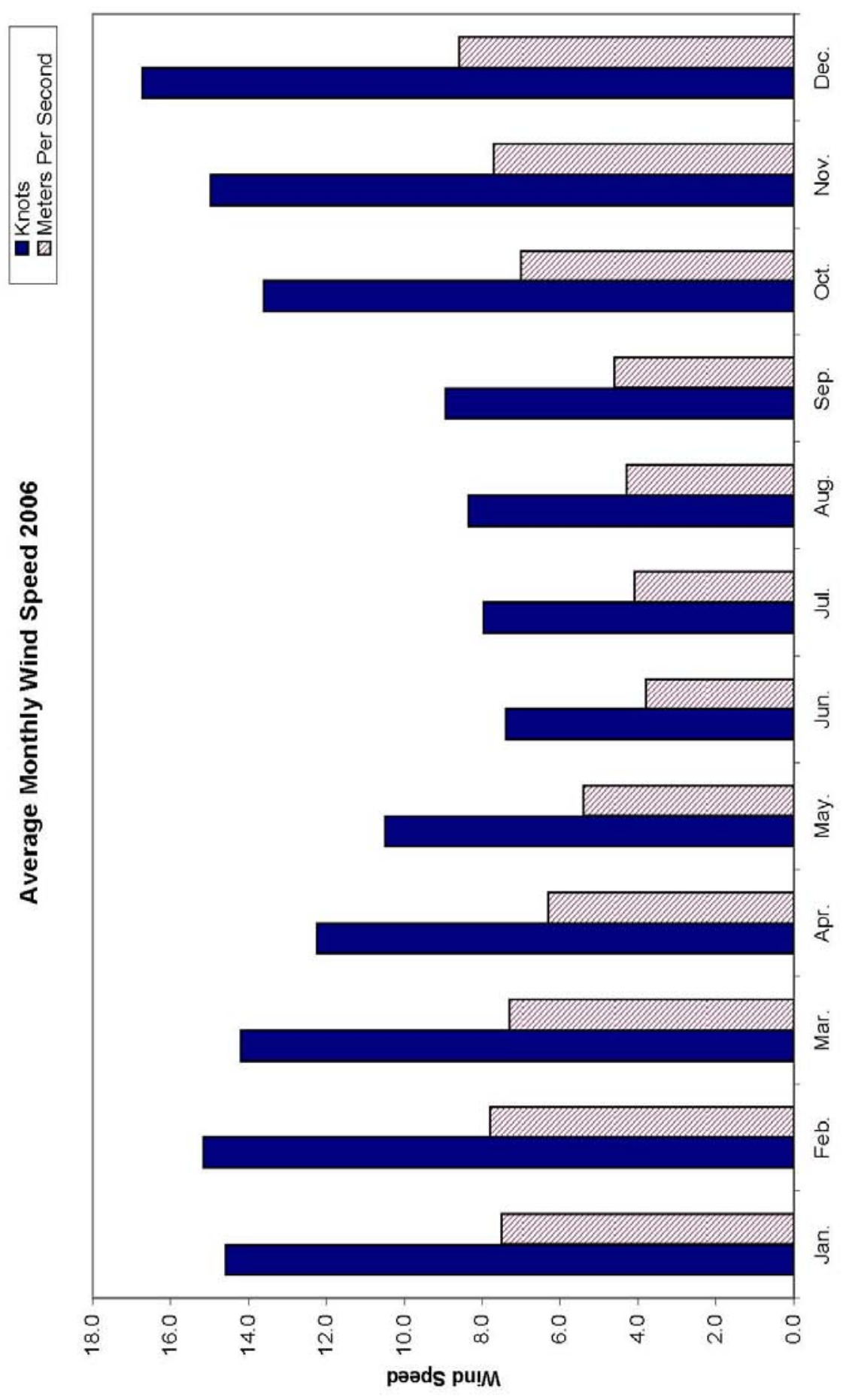




\section{3 - 2006 COMPOSITE WIND ROSE}

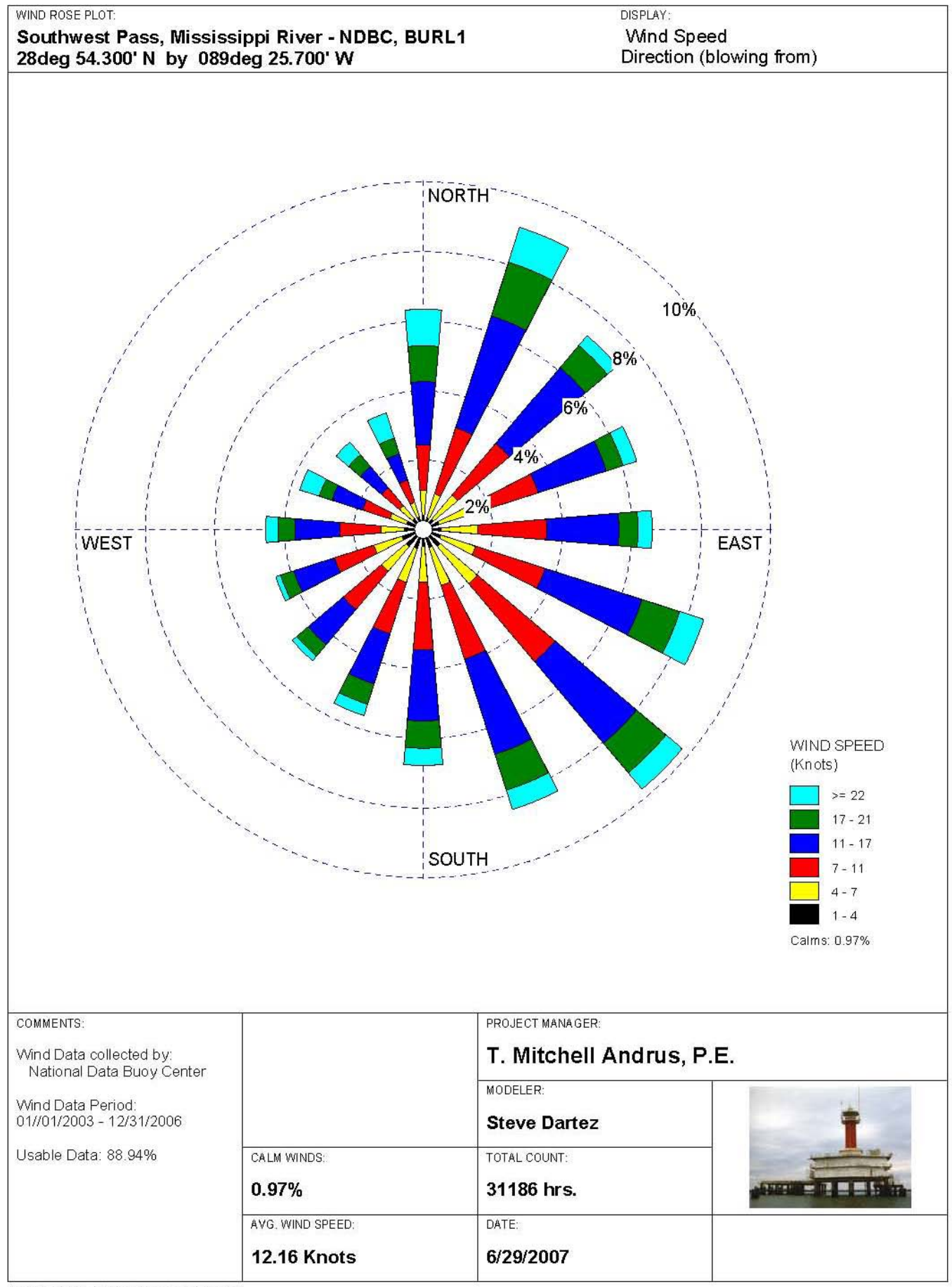

WRPLOT View - Lakes Environmental Software 


\section{3 - WIND ROSE}

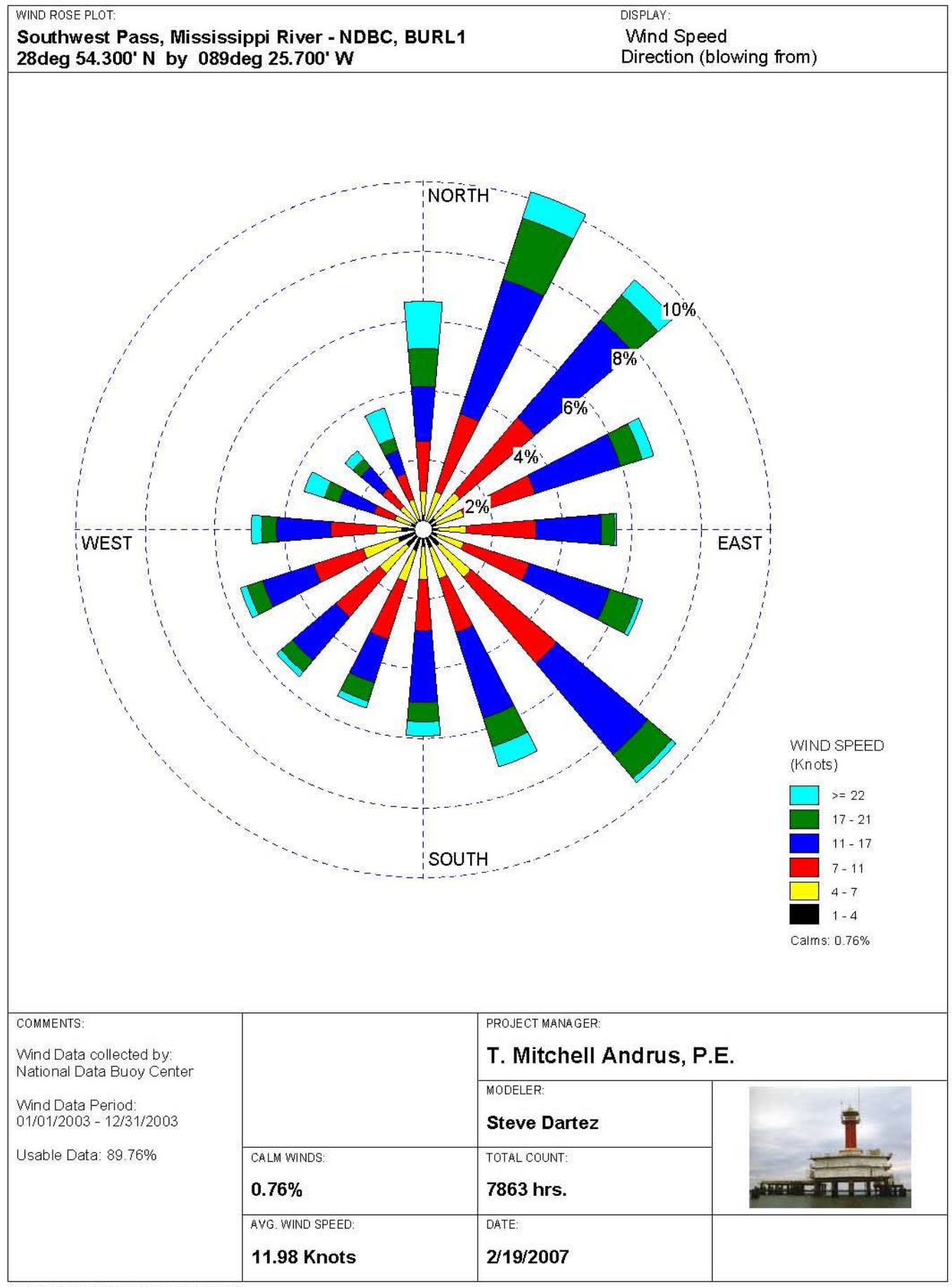

WRPLOT View - Lakes Environmental Software 


\section{4 - WIND ROSE}

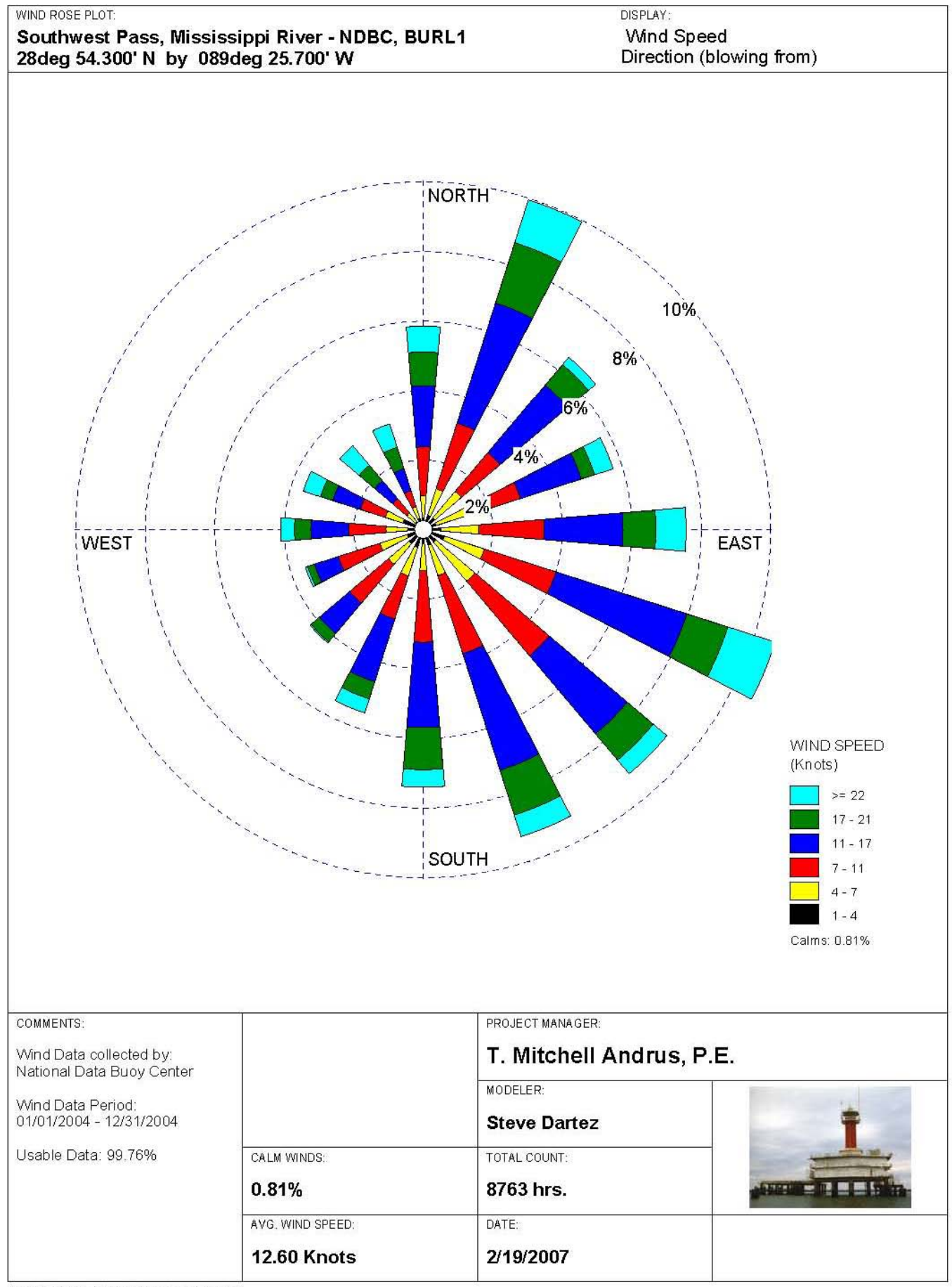

WRPLOT View - Lakes Environmental Software 


\section{5 - WIND ROSE}

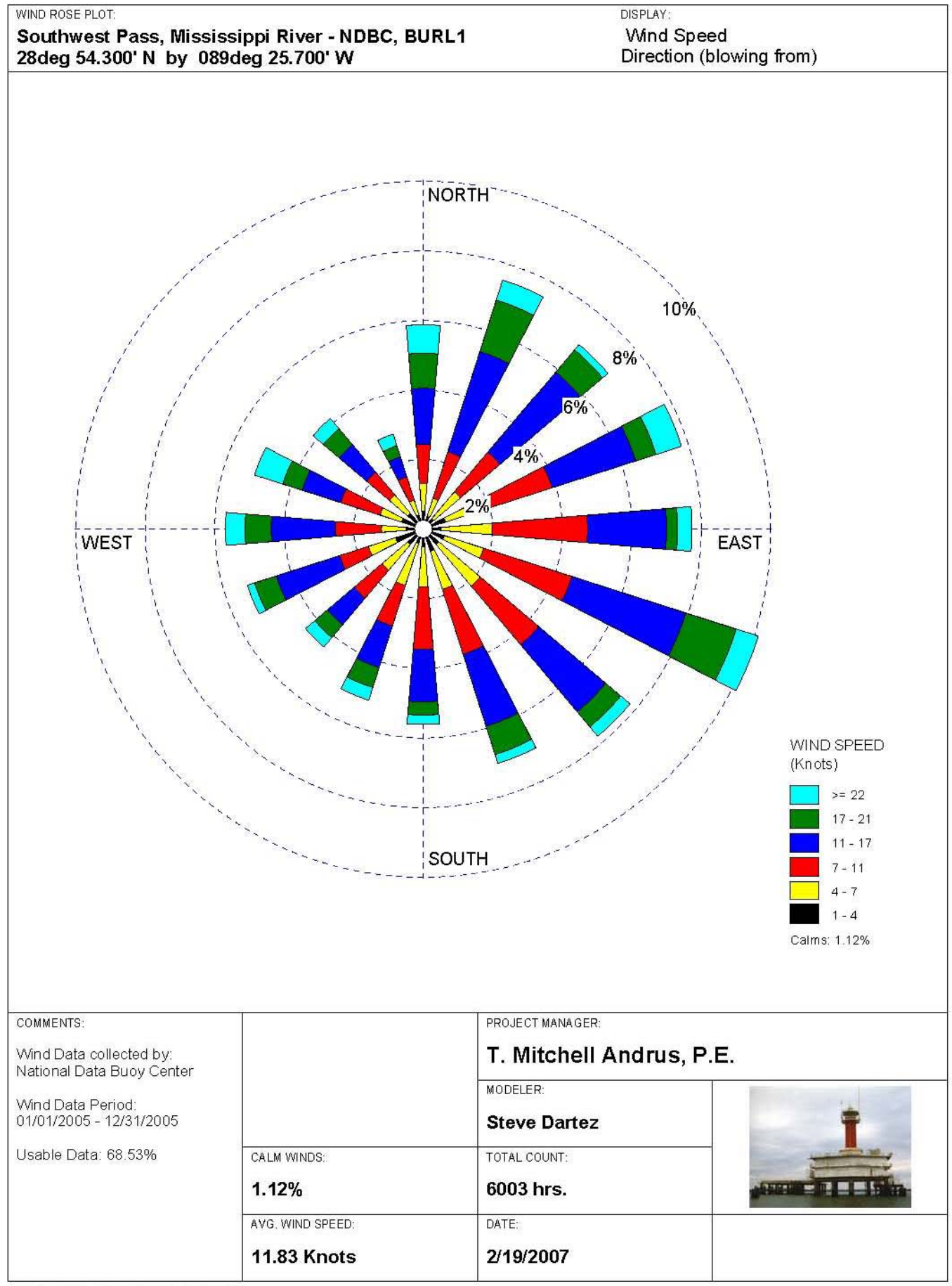

WRPLOT View - Lakes Environmental Software 


\section{6 - WIND ROSE}

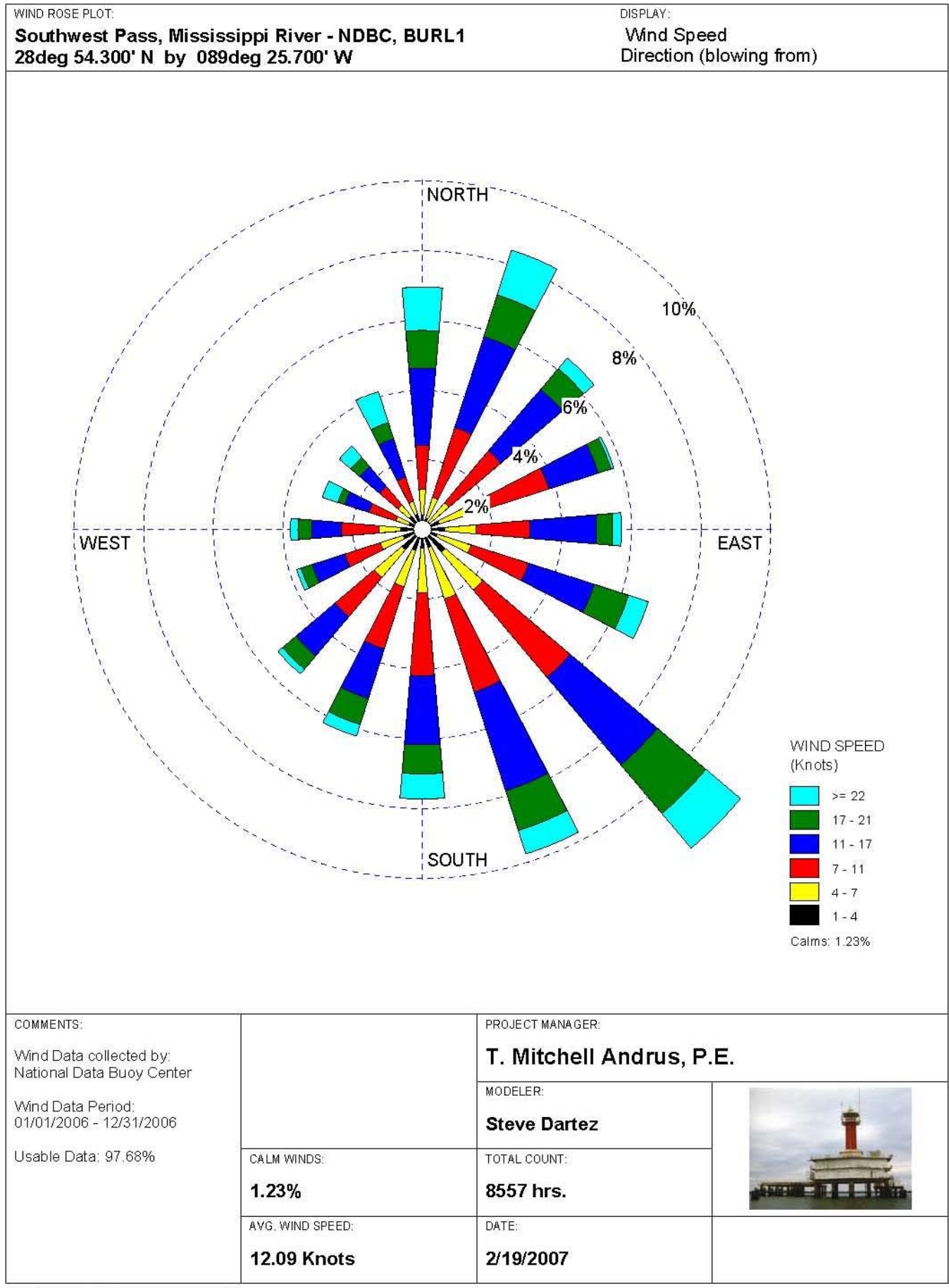

WRPLOT View - Lakes Environmental Software 


\section{4 - 1ST QUARTER WIND ROSE}

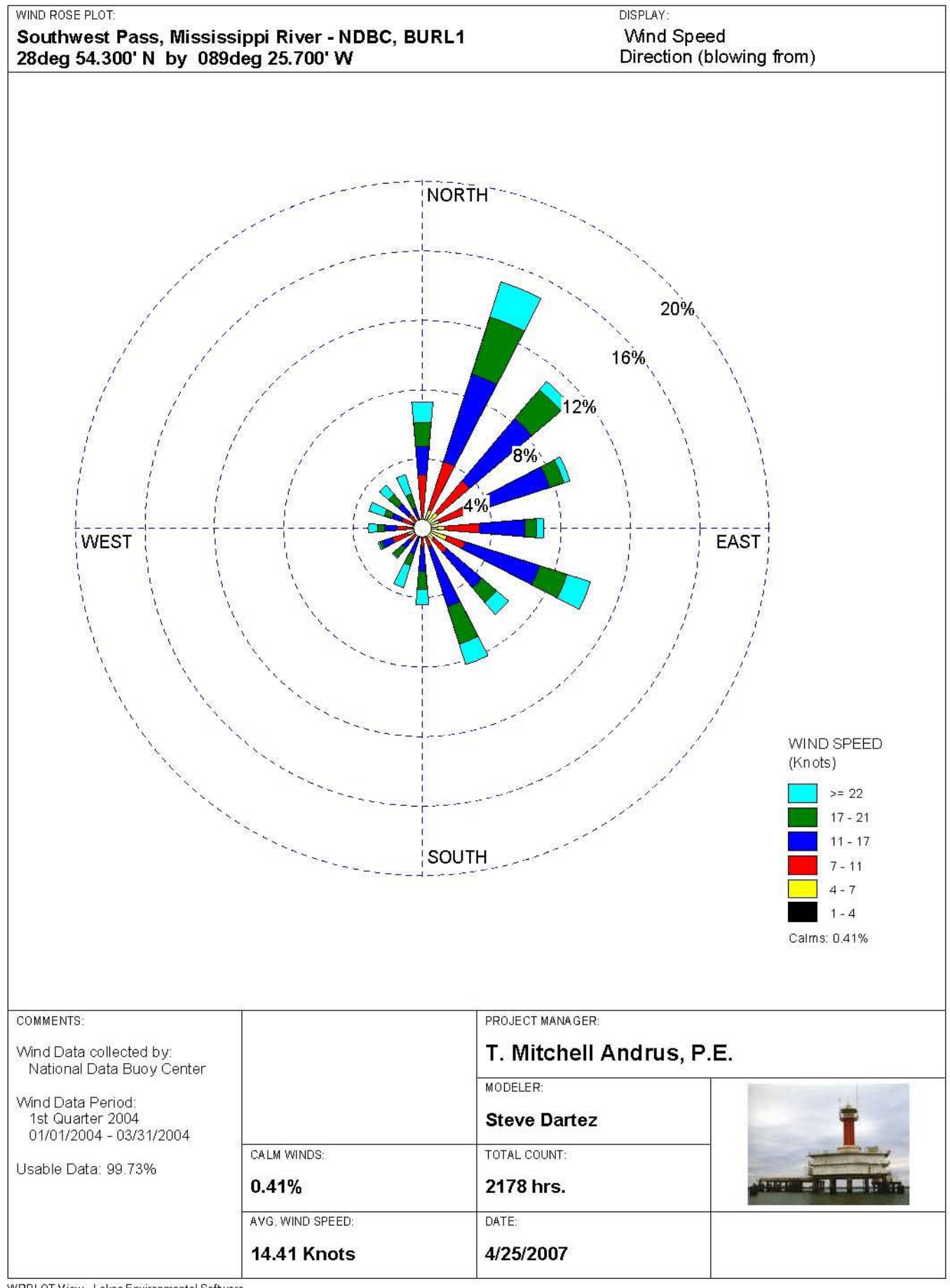




\section{4 - 2ND QUARTER WIND ROSE}

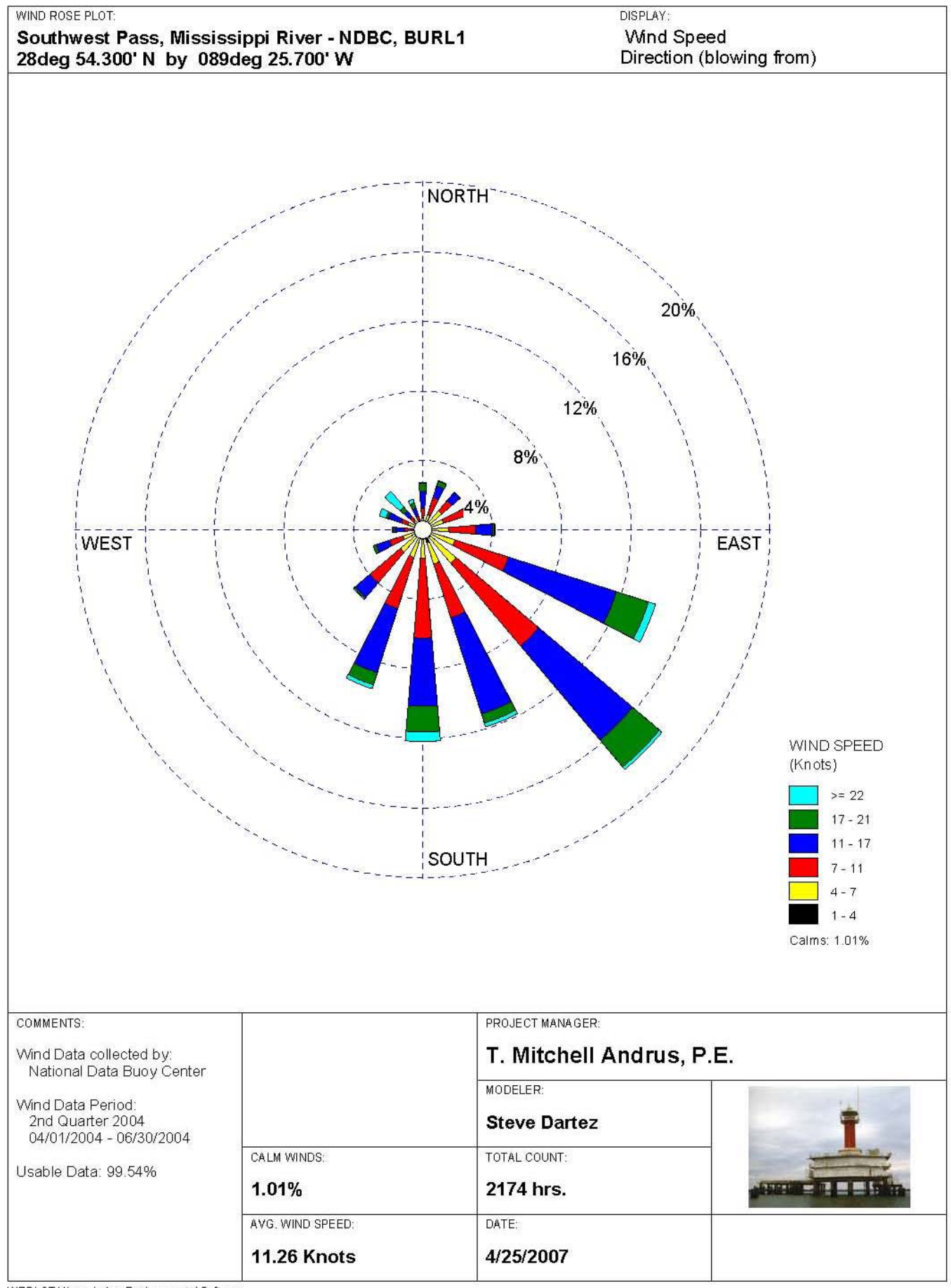




\section{4 - 3RD QUARTER WIND ROSE}

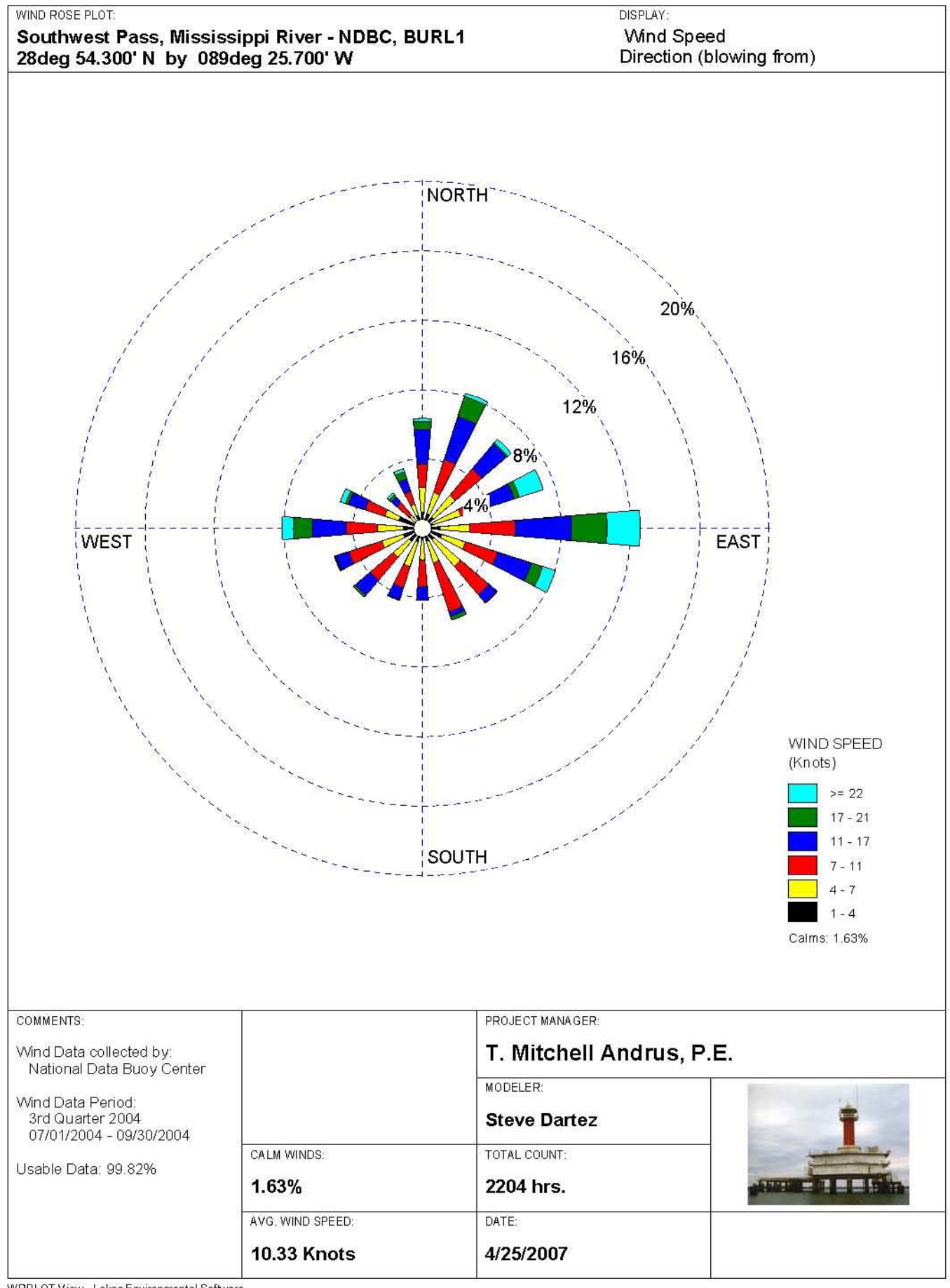




\section{4 - 4TH QUARTER WIND ROSE}

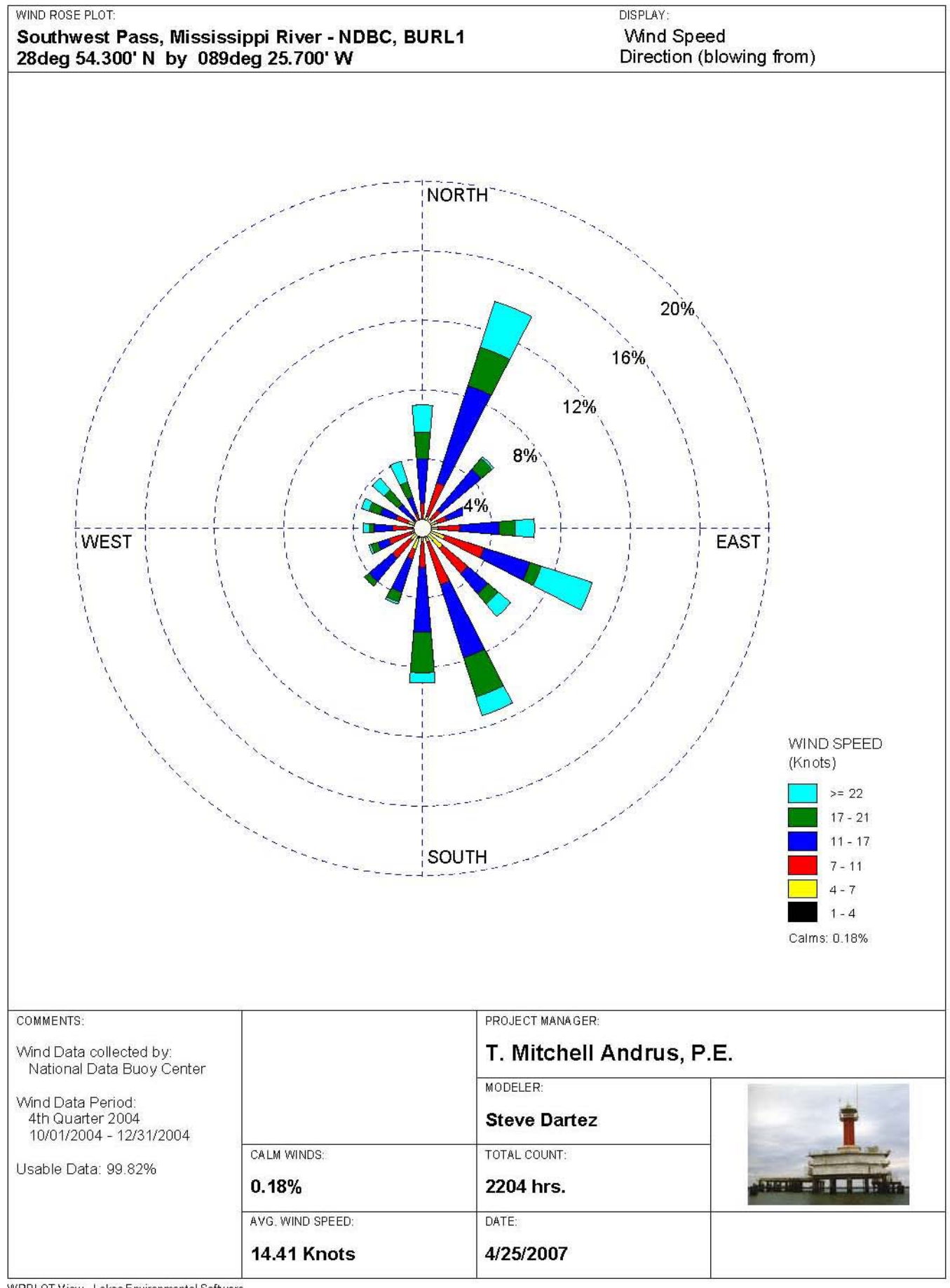




\section{5 - 1ST QUARTER WIND ROSE}

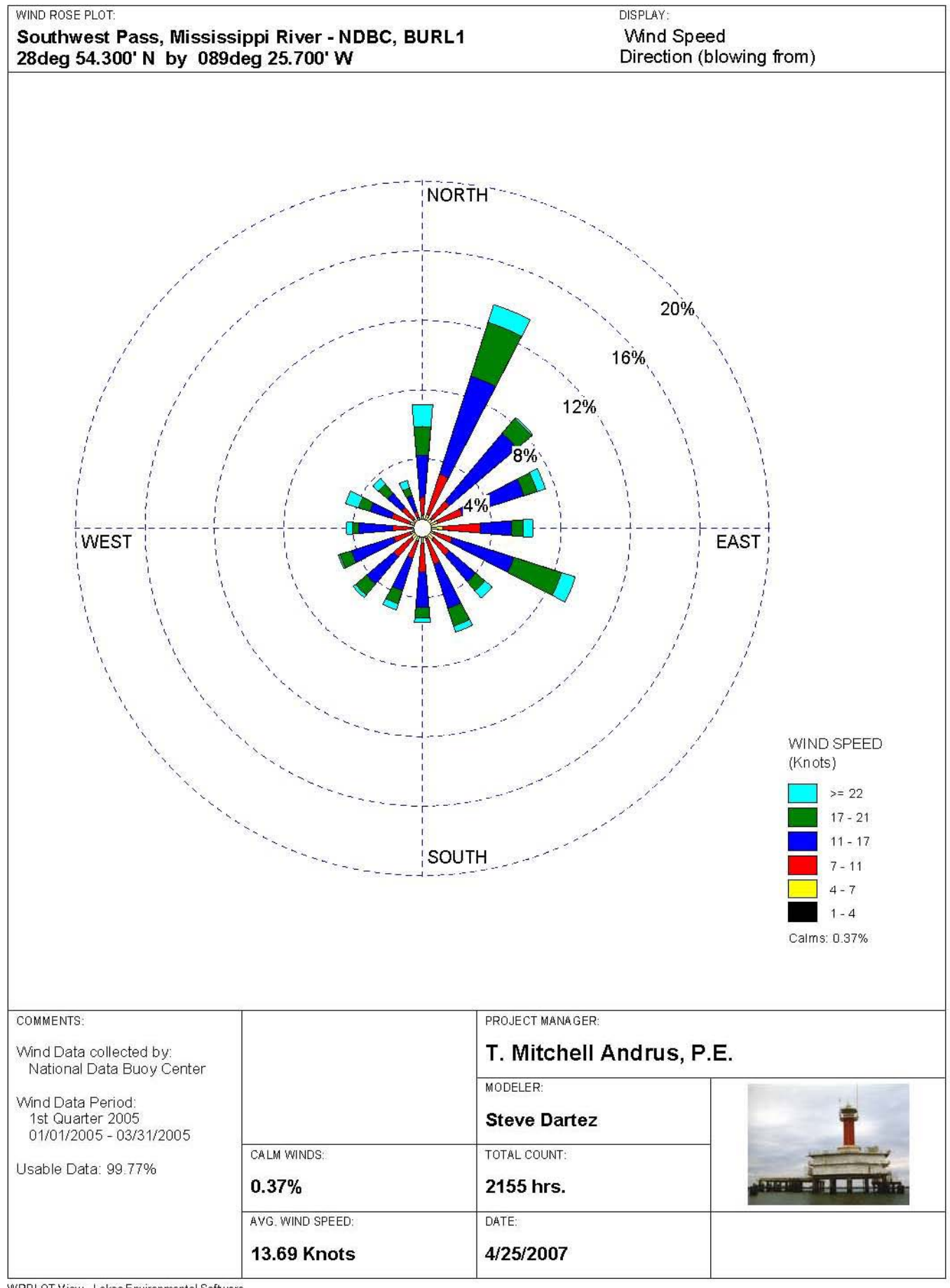




\section{5 - 2ND QUARTER WIND ROSE}

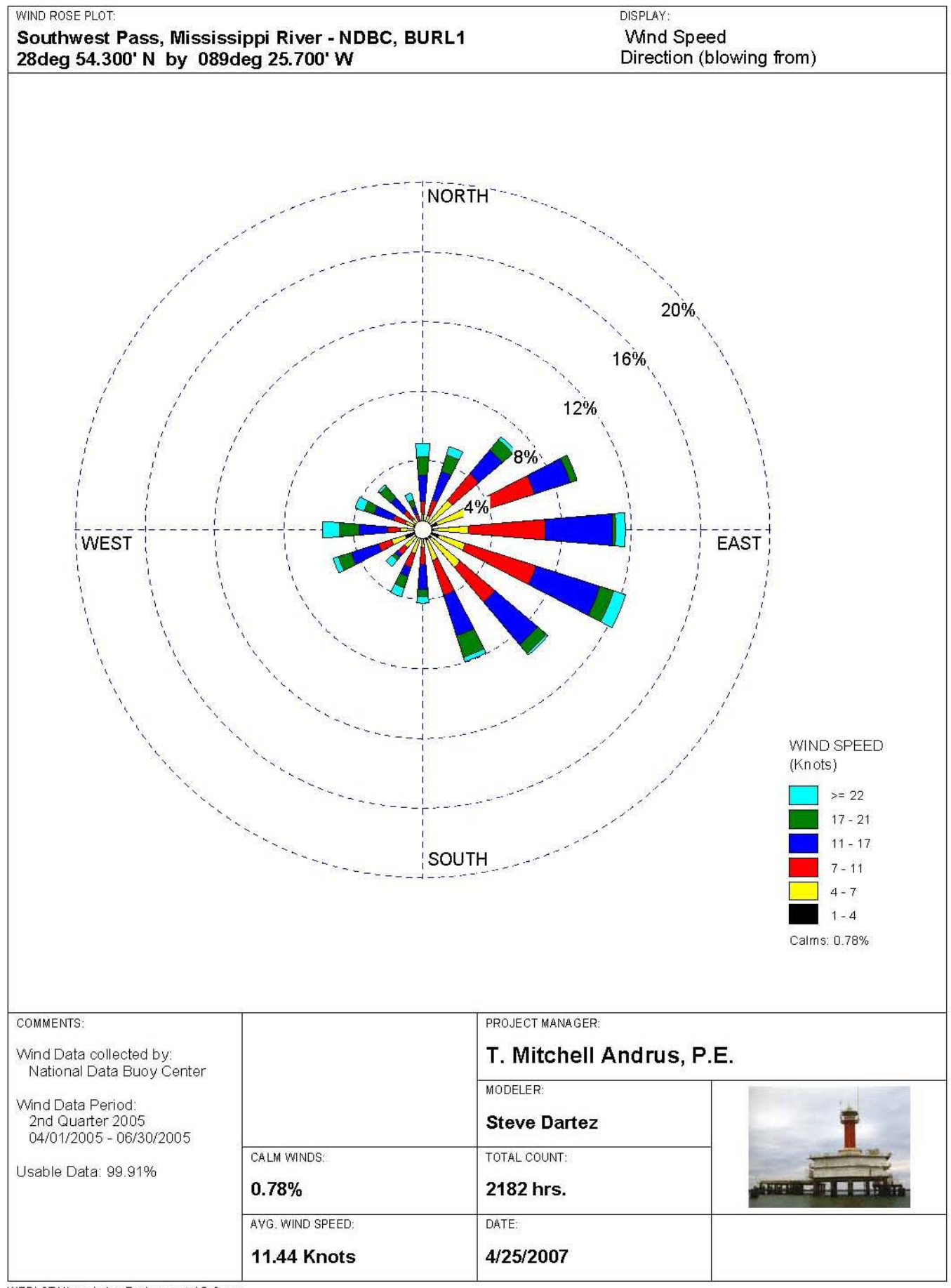




\section{5 - 3RD QUARTER WIND ROSE}

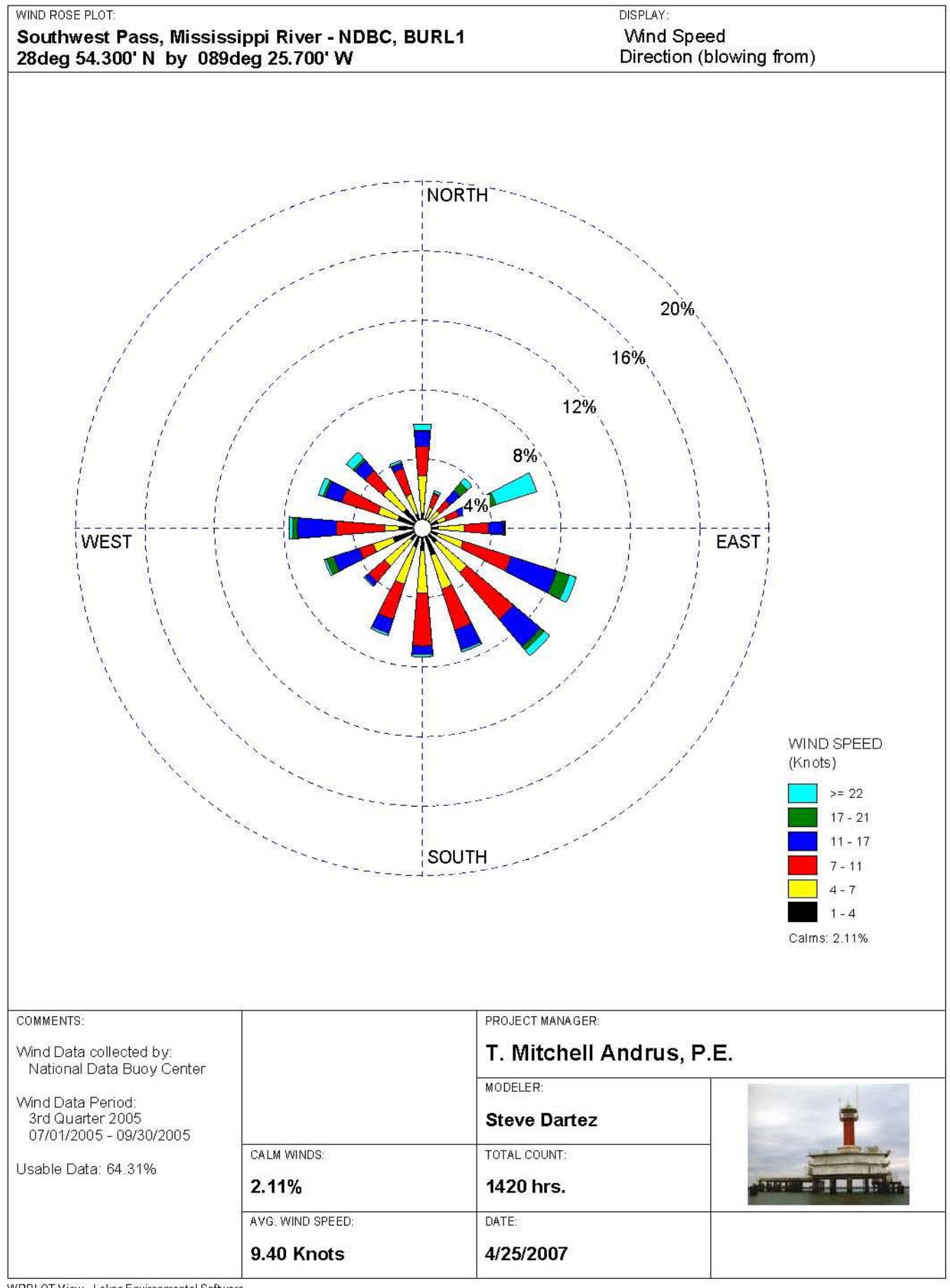




\section{5 - 4TH QUARTER WIND ROSE}

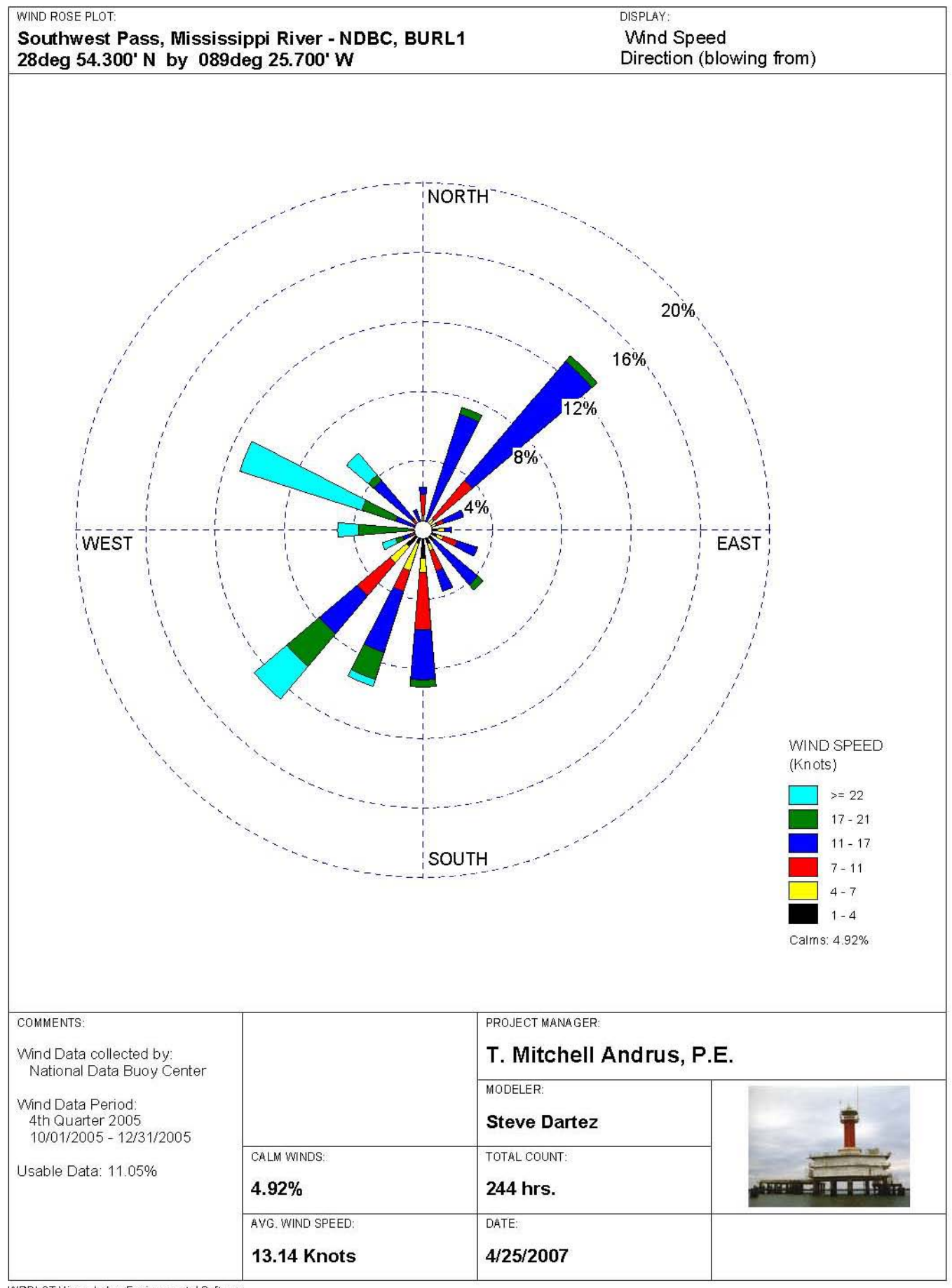




\section{6 - 1ST QUARTER WIND ROSE}

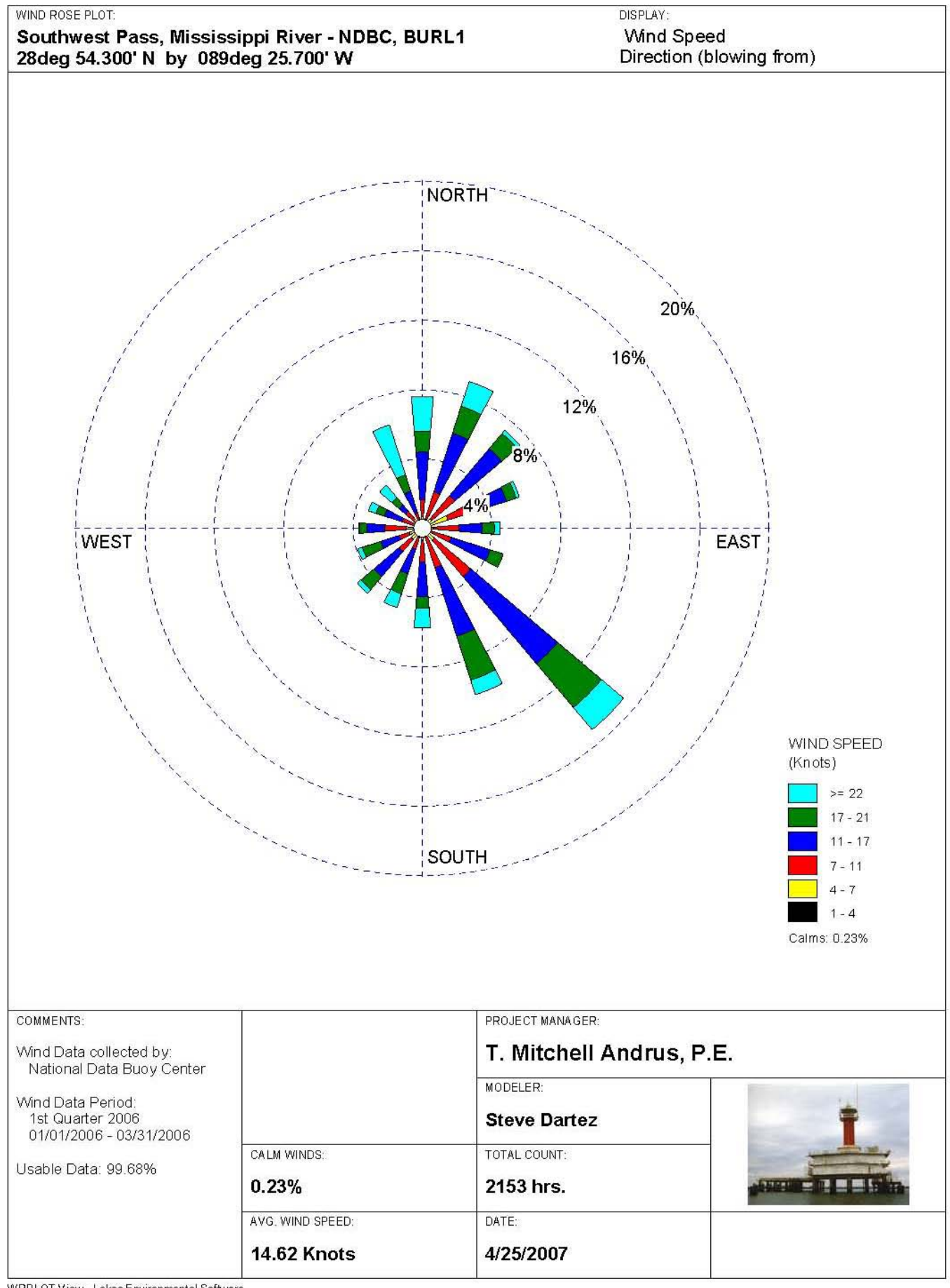




\section{6 - 2ND QUARTER WIND ROSE}

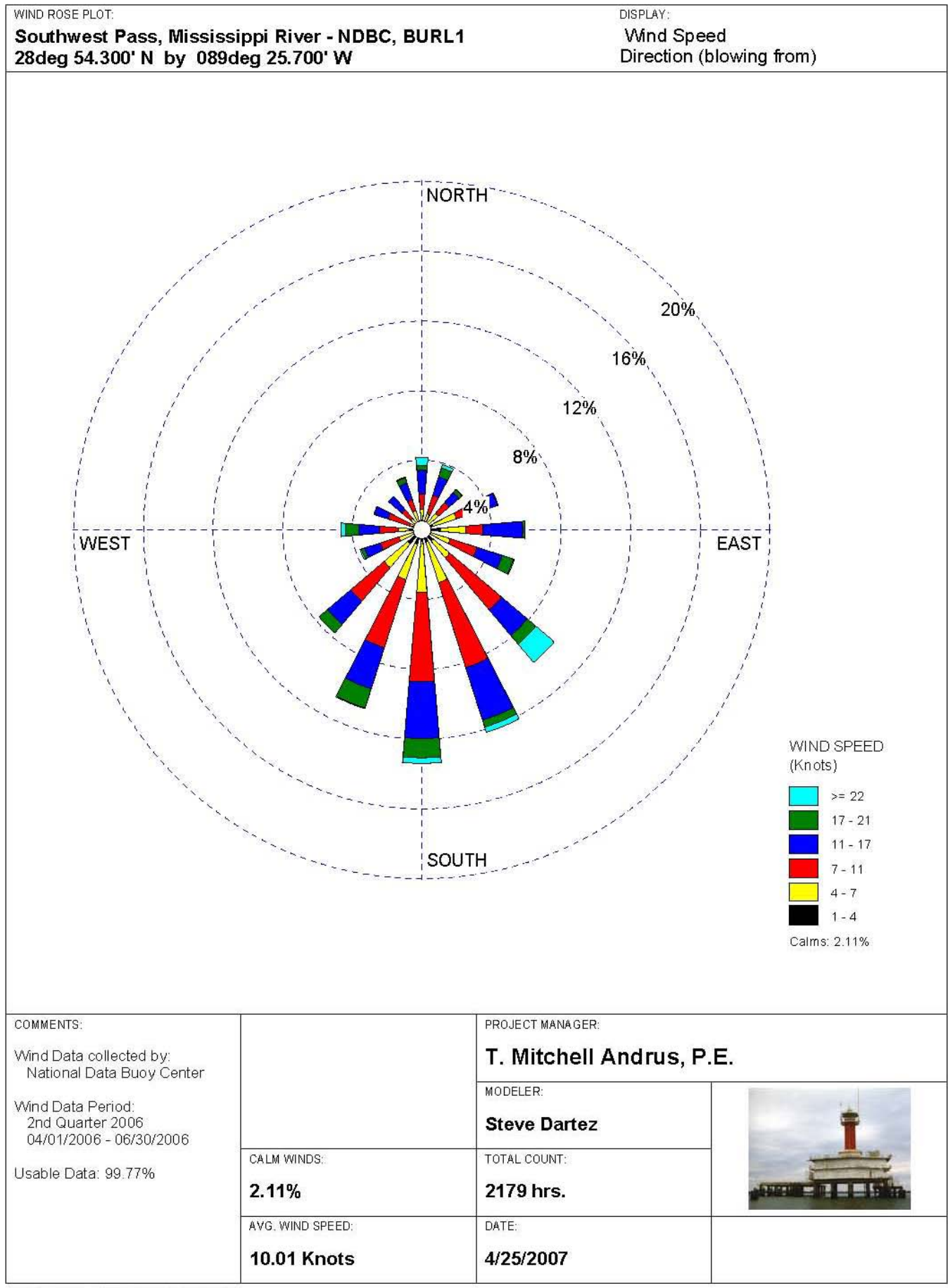

WRPLOT View - Lakes Environmental Software 


\section{VITA}

Thomas Mitchell Andrus was born on July 25, 1974, in Rayne, Louisiana. He is the son of Cotton and Sheila Andrus and the older brother of Mackenzie and Jordan. He graduated from Notre Dame High School in 1992 and went on to receive a Bachelor of Science degree in Civil and Environmental Engineering in December of 1997 from Louisiana State University (LSU). Upon graduation, Mitch accepted a job with Montgomery Watson, an environmental consulting firm, where he was involved in water and wastewater engineering.

As an avid outdoorsman reared in south Louisiana, Mitch yearned to learn more about the history and function of America's largest coastal wetland system. In doing so, he found great disappointment in the rate at which this national treasure is being lost. In March 2000 he took a position with the Louisiana Department of Natural Resources (LDNR) Coastal Engineering Division where he designed and managed numerous coastal restoration projects and studies. It was during this time at LDNR that Mitch became interested in the feasibility of using river diversions as a potentially more sustainable restoration method than traditional projects such as dredging and shoreline protection. He also felt the need for further specialized education and began taking courses at LSU in 2002 and entered the graduate program offered by the Department of Oceanography and Coastal Sciences in 2004 under the guidance of Dr. Samuel Bentley. He is currently working for Coastal Engineering Consultants, Inc. and will be awarded the degree of Master of Science in December of 2007. 